\title{
Development of economic analysis models for woody biomass to biofuels in central Appalachia
}

Jinzhuo Wu

West Virginia University

Follow this and additional works at: https://researchrepository.wvu.edu/etd

\section{Recommended Citation}

Wu, Jinzhuo, "Development of economic analysis models for woody biomass to biofuels in central Appalachia" (2010). Graduate Theses, Dissertations, and Problem Reports. 4675.

https://researchrepository.wvu.edu/etd/4675

This Dissertation is protected by copyright and/or related rights. It has been brought to you by the The Research Repository @ WVU with permission from the rights-holder(s). You are free to use this Dissertation in any way that is permitted by the copyright and related rights legislation that applies to your use. For other uses you must obtain permission from the rights-holder(s) directly, unless additional rights are indicated by a Creative Commons license in the record and/ or on the work itself. This Dissertation has been accepted for inclusion in WVU Graduate Theses, Dissertations, and Problem Reports collection by an authorized administrator of The Research Repository @ WVU.

For more information, please contact researchrepository@mail.wvu.edu. 


\title{
DEVELOPMENT OF ECONOMIC ANALYSIS MODELS FOR WOODY BIOMASS TO
} BIOFUELS IN CENTRAL APPALACHIA

\author{
Jinzhuo Wu \\ Dissertation Submitted to the \\ Davis College of Agriculture, Natural Resources, and Design \\ at West Virginia University \\ in partial fulfillment of the requirements \\ for the degree of \\ Doctor of Philosophy \\ in \\ Forest Resources Science \\ Jingxin Wang, Ph.D., Chair \\ Joseph McNeel, Ph.D. \\ Mark Sperow, Ph.D. \\ Michael Strager, Ph.D. \\ Chris LeDoux, Ph.D.
}

Division of Forestry and Natural Resources

\author{
Morgantown, West Virginia \\ 2010
}

Keywords: Biofuels, Optimization, Woody biomass, Sensitivity analysis, Mathematical programming, Logistics. 


\title{
ABSTRACT \\ DEVELOPMENT OF ECONOMIC ANALYSIS MODELS FOR WOODY BIOMASS TO BIOFUELS IN CENTRAL APPALACHIA
}

\author{
Jinzhuo $\mathrm{Wu}$
}

\begin{abstract}
Concerns about volatile crude oil prices, energy security, and environmental issues are driving the production and use of renewable energy in the United States. Woody biomass can be used as feedstock for solid or liquid fuels or electricity generation. An economic analysis model was developed to estimate the delivered cost of woody biomass using different woody biomass handling systems. The model was designed to minimize the total annual delivered cost of woody biomass and applied to the central Appalachian region. Six forest districts were used to represent the destination of woody biomass supply. When demand is 900 metric tons (990 short tons) of dry woody biomass per day, for that base case scenario, the average delivered cost per unit of woody biomass ranged from $\$ 2.77$ to $\$ 3.01$ per GJ ( $\$ 44.07$ to $\$ 47.77$ per short ton) among the different handling systems. The delivered cost was found to be mostly affected by woody biomass demand, mill residue availability, and mill residue purchase price, while skidding distance had the least impacts on the delivered cost.

The economic feasibility of a woody biomass-based ethanol facility was analyzed using a mixed integer programming model. The model is designed to maximize the net present value (NPV) of a facility over its economic life. A case study was conducted in the central Appalachian hardwood region. Eleven feasible plant locations were identified based on the requirements of site selection. Results showed that the optimal plant location was in Buckhannon, West Virginia. The NPV of the plant, with a demand of 1,814 metric tons/day of woody biomass and plant life of 20 years, varied from $\$ 17.28$ million to $\$ 35.54$ million among different systems. Ethanol production cost averaged approximately US $\notin 50.85-52.38$ per liter (\$1.92-\$1.98 per gallon). Factors such as biomass availability, mill residue purchase price, plant investment and capacity, ethanol yield, and financing are sensitive to ethanol production cost. Findings suggest that a woody biomass-based ethanol facility in central Appalachia could be economically feasible under certain operational scenarios.

Liquid fuels from coal and biomass have the potential to reduce petroleum fuel use and $\mathrm{CO}_{2}$ emission. West Virginia is a heavily forested state and also rich in coal reserves. A multiequation model was developed to assess the economics of a coal/biomass-to-liquids (CBTL) fuel plant in West Virginia. Specifically, the objective was to minimize the total annual cost subject to a series of regional supply, demand, and other constraints. The results indicated that the required selling price (RSP) of Fischer-Tropsch (FT) diesel for a 40,000 barrel-per-day CBTL plant with coal/biomass ratio of $85 / 15$ varied between $\$ 79.30$ and $\$ 79.57$ per barrel using the different biomass handling systems. The RSP of FT diesel heavily depended upon plant capacity, capital cost, coal price, and liquid fuel yield. The crude-oil-equivalent price of FT fuels must be above $\$ 62 / \mathrm{bbl}$ for a CBTL plant to be profitable and a feasible long-term option in central Appalachia.
\end{abstract}




\section{ACKNOWLEDGEMENTS}

I would like to give my full gratitude to my major professor Dr. Jingxin Wang for keeping me pointed in the right direction and unlimited support throughout my study. His advice and inspiration were imperative to the completion of my study. I am glad to have the opportunity to finish the doctoral degree under his guidance. I would also like to thank my advisory committee members, Dr. Joseph McNeel, Dr. Mark Sperow, Dr. Michael Strager, and Dr. Chris LeDoux for their valuable comments and advice.

I would like to thank Mr. Tony Goff and Dr. Qingzheng Cheng for their assistance on data collection and valuable friendship. Special thanks go to Dr. Tatiana Borisova and Dr. Jerald Fletcher from the Division of Resource Management at WVU for their assistance in mathematical program execution. I also appreciate Mr. Steve Harouff for his generous and knowledgeable suggestions in dealing with GIS related issues.

Finally, I must thank my husband, Wenshu Lin, for his love and endless support. I thank my parents and brother for always supporting me throughout my whole life. 


\section{TABLE OF CONTENTS}

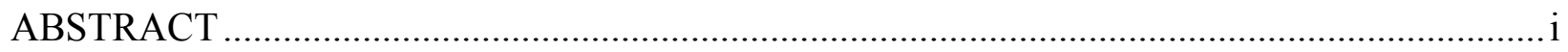

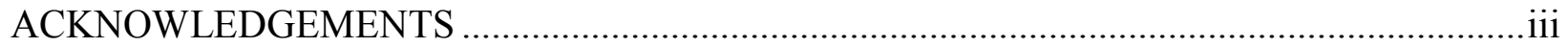

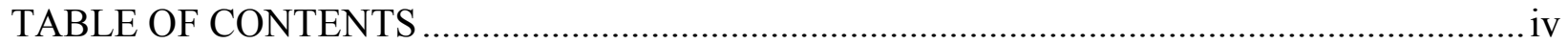

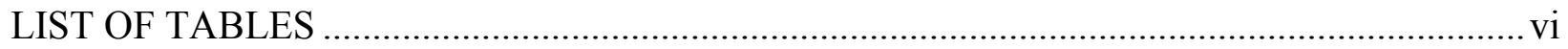

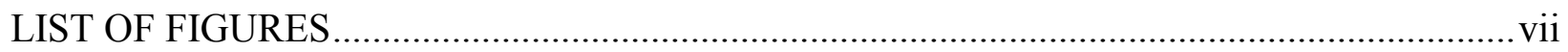

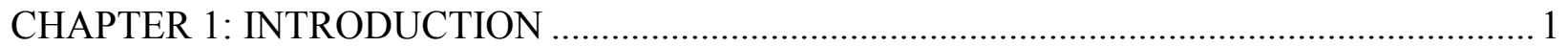

CHAPTER 2: AN ECONOMIC ANALYSIS MODEL OF WOODY BIOMASS UTILIZATION

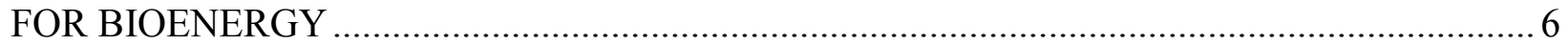

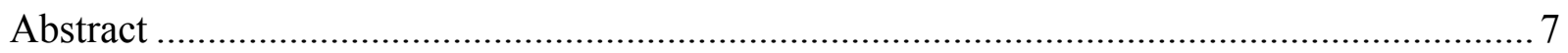

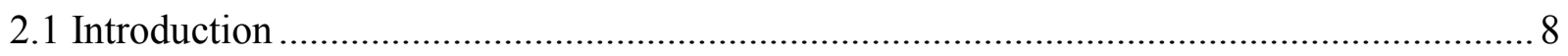

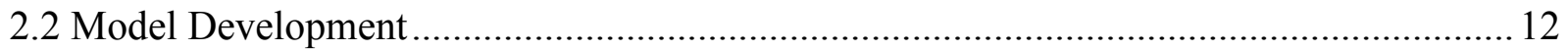

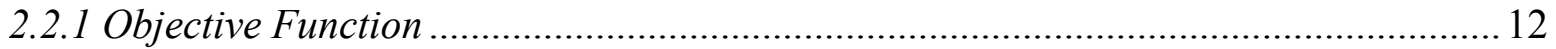

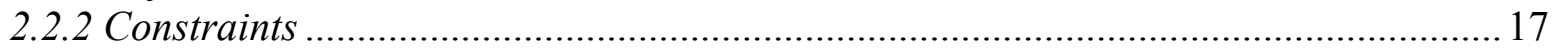

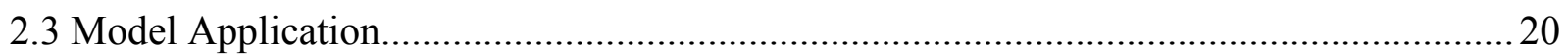

2.3.1 Woody Biomass Availability and Accessibility .........................................................2 21

2.3.2 Logging Residue Handling Productivities and Costs ...............................................2

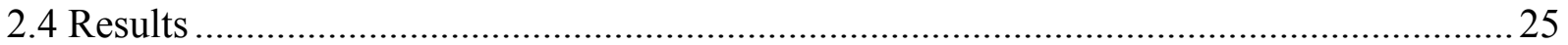

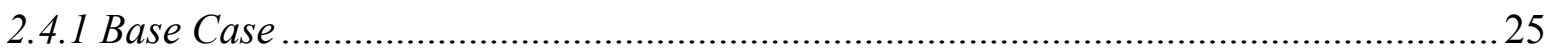

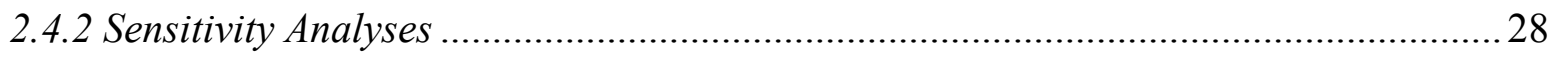

2.5 Conclusions and Discussion..................................................................................... 34

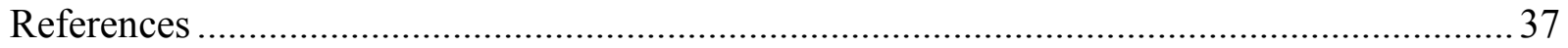

Appendix 2.A. List of symbols ...................................................................................... 43

CHAPTER 3: ECONOMIC FEASIBILITY OF A WOODY BIOMASS-BASED ETHANOL

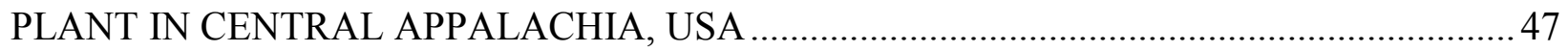

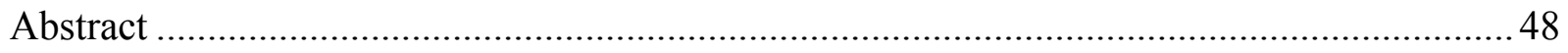

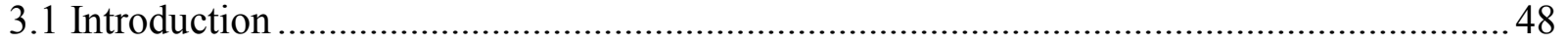

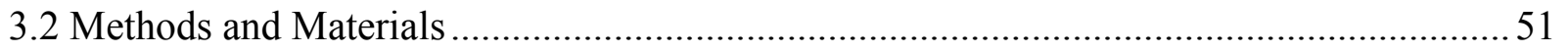

3.2.1. Model development …………………………………...................................... 51

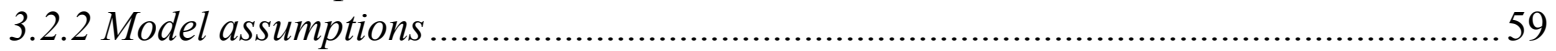

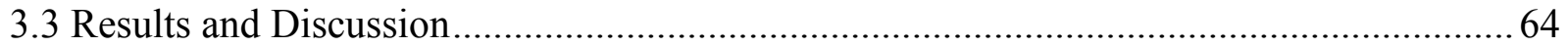

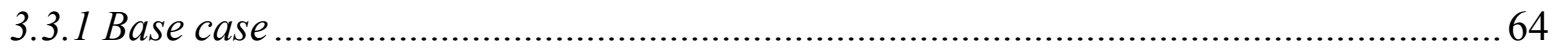

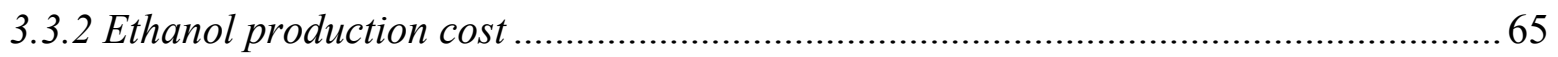

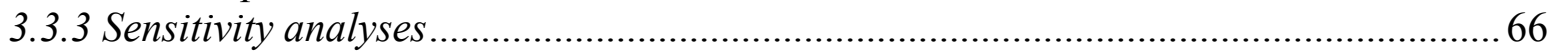

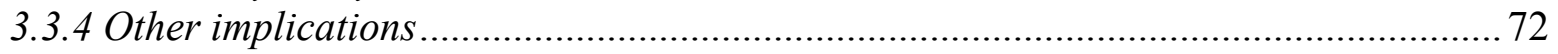

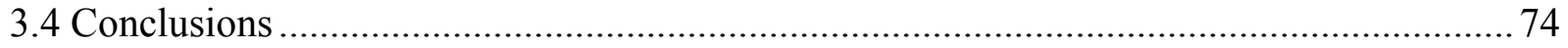

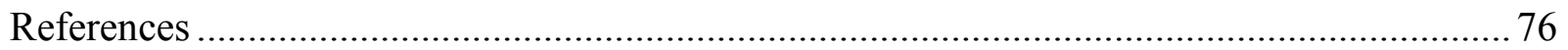

Appendix 3.A. Sets, parameters, and variables ................................................................ 81

CHAPTER 4: ECONOMIC ASSESSMENT OF COAL AND BIOMASS TO LIQUID FUELS

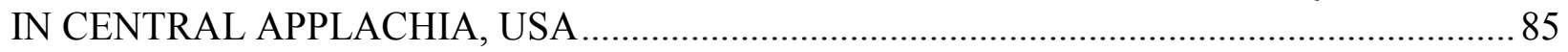

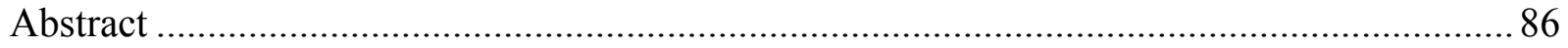

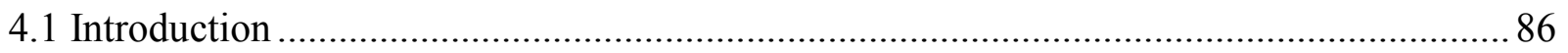




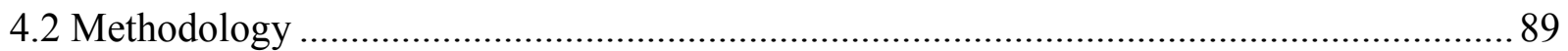

4.2.1 Description of the study area and feedstock availability ..........................................8 89

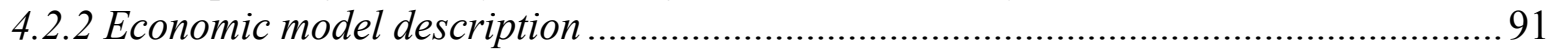

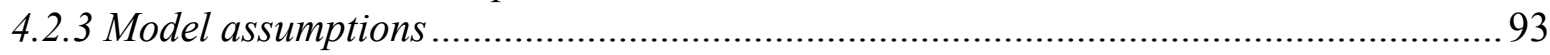

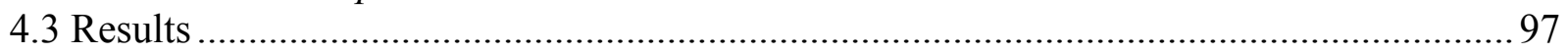

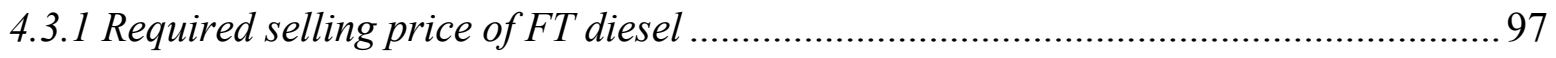

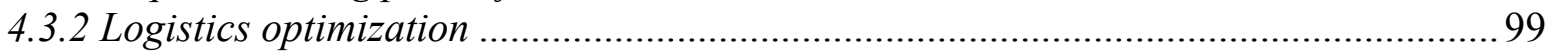

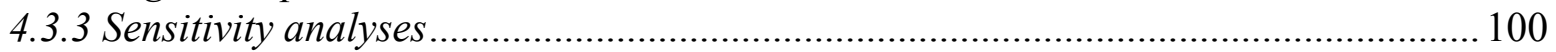

4.3.4 Diesel replacement and greenhouse gas emissions .................................................. 105

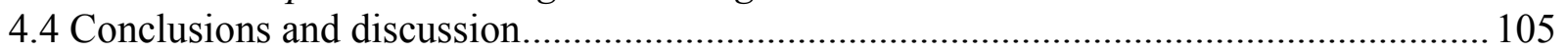

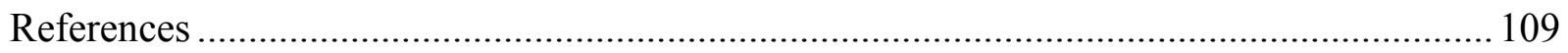

Appendix 4.A. Economic analysis model specification......................................................113

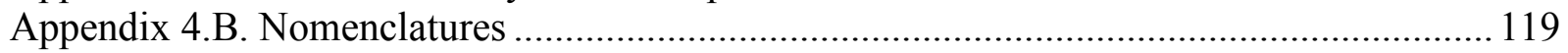

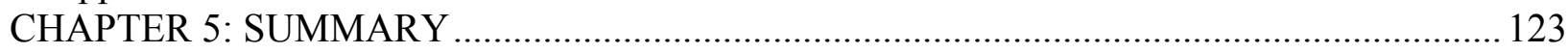

APPENDIX I: WOODY BIOMASS DELIVERED COST MODEL ...................................... 126

APPENDIX II: ECONOMIC ANALYSIS MODEL FOR A WOOD BIOMASS PLANT ........ 140

APPENDIX III: ECONOMIC ANALYSIS MODEL FOR A CBTL PLANT …………….......... 163 


\section{LIST OF TABLES}

Table 2.1. Assumptions for the woody biomass handling machines ${ }^{\mathrm{a}}$...................................... 24

Table 2.2. Cost calculations for the different handling machines. ......................................... 25

Table 2.3. Optimization summary of woody biomass handling by system in the base case. .......26

Table 3.1. Cost assumptions for woody biomass handling machines in central Appalachia........ 62

Table 3.2. Assumptions for a 1,814 t/day woody biomass-based ethanol plant. ........................6 63

Table 3.3. Optimization of the woody biomass-based ethanol facility by biomass handling

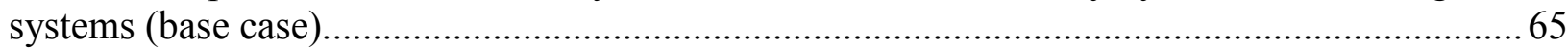

Table 4.1. Woody biomass in the central Appalachian region ${ }^{\mathrm{a}}$............................................. 90

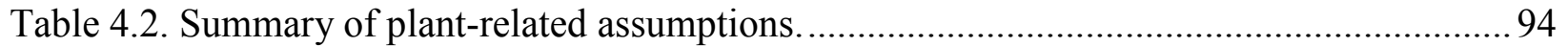

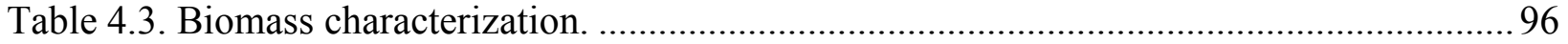

Table 4.4. Summary of cost assumptions by woody biomass handling machines......................96

Table 4.5. Biomass delivered to the CBTL plant by system $(40,000 \mathrm{bbl} /$ day) .......................... 98 


\section{LIST OF FIGURES}

Figure 1.1. Wood residues: (a) logging residue, (b) mill residue................................................2

Figure 2.1. The geographical location of West Virginia, USA.............................................. 12

Figure 2.2. Modeled woody biomass supply and demand locations in West Virginia. (a) Annual

logging residue production and mill residue distribution. (b) Selected woody biomass demand

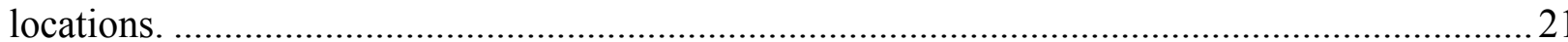

Figure 2.3. Woody biomass delivered per year by handling system (dry weight).................... 27

Figure 2.4. Delivered cost composition of logging residue by woody biomass handling system

for the base case. .................................................................................................... 28

Figure 2.5. Sensitivity analyses of the woody biomass delivered cost by residue availability and

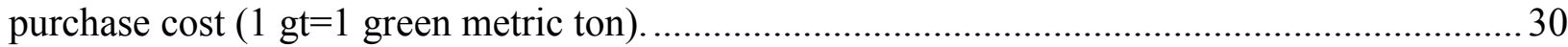

Figure 2.6. Sensitivity analyses of the delivered cost by woody biomass demand, skidding

distance, and fuel price (dry weight) ............................................................................. 33

Figure 3.1. Pre-selected woody biomass-based potential ethanol plant locations and biomass

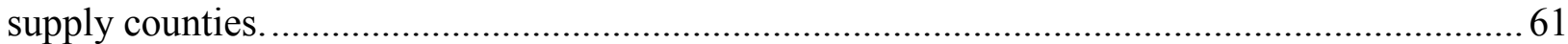

Figure 3.2. Net present value and internal rate of return vs. ethanol price. ............................ 67

Figure 3.3. Ethanol production cost vs. feedstock availability and cost by system (wet basis).... 69

Figure 3.4. Ethanol production cost vs. plant assumptions by system (dry weight)................... 70

Figure 4.1. The scope of the study area. The bars symbolize the annual coal and woody biomass

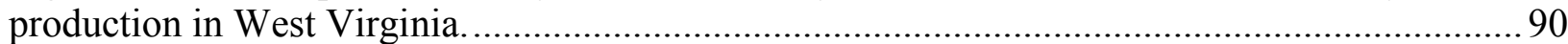

Figure 4.2. Predicted annual switchgrass production on (a) hay lands and (b) reclaimed mine fields in West Virginia assuming 10\% of lands used......................................................... 91

Figure 4.3. Annual feedstock requirement curve for each coal/biomass ratio.......................... 95

Figure 4.4. Cost components of one barrel of FT diesel-equivalent liquid fuel by coal/biomass

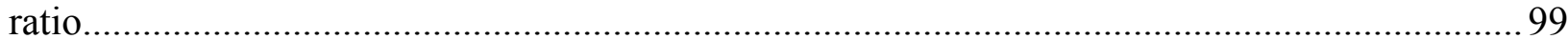

Figure 4.5. Feedstock delivered to the CBTL plant by month and by state............................ 100

Figure 4.6. Effects of feedstock availability and costs on the RSP ....................................... 102

Figure 4.7. Effects of plant-related assumptions on the RSP ........................................... 103

Figure 4.8. Crude oil price projections and COE of FT diesel products................................ 107 


\section{CHAPTER 1: INTRODUCTION}

The increasing volatility of crude oil prices, the heavy dependence of the U.S. on imports for foreign oil, and environmental issues have together sparked strong national interest in the production and use of renewable energy in the United States. Biomass is regarded as a key renewable resource in future energy systems and can be upgraded to solid or liquid fuels, or used for electricity generation. Benefits of using biomass as feedstock for biofuels include reduced use of nonrenewable fuels, less dependency on foreign oil, stabilization of income in rural areas, and reduced carbon dioxide emissions to the atmosphere (Office of Technology Assessment 1993). Furthermore, linking biomass collection and transportation to economically generate raw material for bioenergy can create new, high-skilled jobs for people specializing in engineering systems, computers, economics, and international trade while providing new opportunities for forest managers, biologists, and engineers (Vogt et al. 2005).

Woody biomass (Figure 1.1), which includes residues produced during timber harvesting, fuelwood extracted from forestlands, and residues generated at primary and secondary wood processing facilities, is a potentially important feedstock for bioenergy (Kaylen et al. 2000, Bridgwater et al. 2002, Thek and Obernberger 2004, Caputo et al. 2005). To date, energy from woody biomass has played a relatively small role in terms of the overall U.S. energy use, making up only 3 percent of the total consumed (Duncan 2004). Demand for bioenergy in the U.S. is growing due to a concerted effort to reduce the nation's dependence on fossil fuels. 


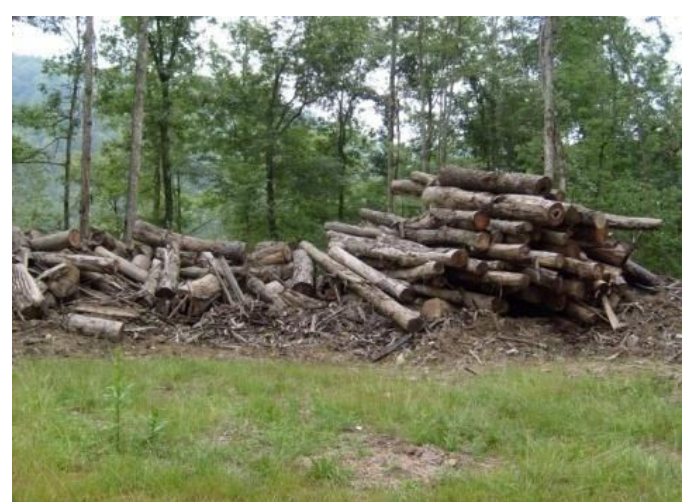

(a)

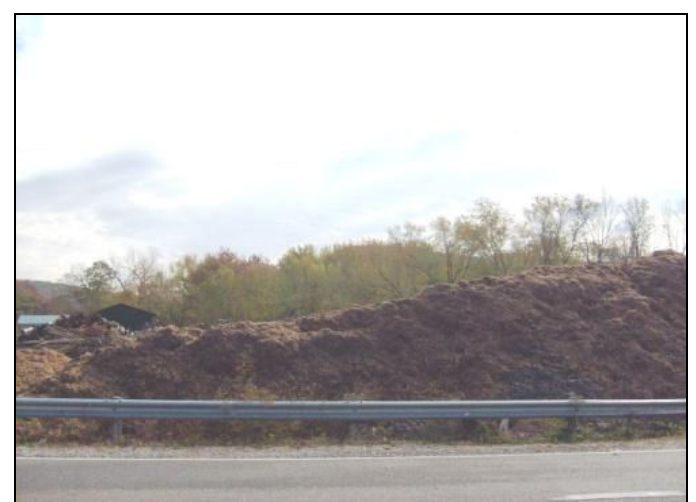

(b)

Figure 1.1. Wood residues: (a) logging residue, (b) mill residue.

The state of West Virginia, located in the central Appalachian region, is one of the most heavily forested states in the U.S., and produces an estimated 2.41 million dry tons of woody biomass per year (Wang et al. 2006). Even with this significant and low cost resource, limited economic value is generated. West Virginia is also the nation's second largest coal-producing state, and produced approximately 161 million tons of coal in 2007 , about $13 \%$ of the U.S. total (West Virginia Coal Association 2007). To date, no commercial-scale facility is operating to convert woody biomass or coal and woody biomass into bioenergy or bioproducts in the state. Industries that could use wood as a feedstock, such as biorefining, biochemicals, and biopolymers, have limited start-up potential due to a lack of financial capital and economic related information. Research on the economic feasibility of using woody biomass as feedstock for biofuels (i.e., bioethanol, biodiesel) in the state is a critical need.

Previous studies (e.g., Wooley et al. 1999, Kaylen et al. 2000) have evaluated the economics of converting lignocellulosic biomass (e.g., crop residues, woody biomass, energy crops, or municipal solid waste) into bioenergy or bioproducts. However, these studies mainly focused on the Midwestern U.S. and the results were either site specific or assumption dependent. For example, most studies assumed the price paid for "as-received" feedstock 
(woody biomass or agricultural residue) was constant. However, this price may vary depending on plant location, biomass density and availability, and other market factors. A guaranteed supply of woody biomass at a competitive price within a reasonable radius of a potential bioenergy plant is critical for profitability, and viability, of the plant. Information on delivered cost of woody biomass was not well documented in the region. Systematic economic models that are suitable for woody biomass to biofuels are critically needed to help investors/developers identify biomass opportunities. The risk of operating a woody biomass-based bioenergy plant is uncertain in view of dynamic technology, government policies, business opportunities, and markets; therefore, detailed analyses are necessary to estimate the sensitivity levels of production and profitability.

Specifically, the objectives of this dissertation are to: (1) develop a mathematical model to evaluate the delivered cost of woody biomass from stump to a woody biomass utilization plant, (2) assess the economic feasibility of a woody biomass-based ethanol facility in West Virginia, and (3) estimate the production cost of liquid fuels from local coal and biomass resources in the central Appalachian region. 


\section{References}

Bridgwater, A.V., Toft, A.J., and Brammer, J.G. 2002. A techno-economic comparison of power production by biomass fast pyrolysis with gasification and combustion. Renewable and Sustainable Energy Reviews 6: 181-248. doi:10.1016/S1364-0321(01)00010-7.

Caputo, A.C., Palumbo, M., Pelagagge, P.M., and Scacchia, F. 2005. Economics of biomass energy utilization in combustion and gasification plants: effects of logistic variables. Biomass and Bioenergy 28: 35-51.

Duncan, M. 2004. U.S. federal initiatives to support biomass research and development. Journal of Industrial Ecology. Vol 7 (3-4):193-201.

Kaylen, M., Vandyne, D.L., Choi, Y.S., Blase, M., 2000. Economic feasibility of producing ethanol from lignocellulosic feedstocks. Bioresource Technology 72(1), 19-32.

Office of Technology Assessment. 1993. Potential environmental impacts of bioenergy crop production. Background Paper TOA-BP-E-118. U.S. Congress, OTA, Washington, D.C. $71 \mathrm{pp}$.

Thek, G., and Obernberger, I. 2004. Wood pellet production costs under Austrian and in comparison to Swedish framework conditions. Biomass and Bioenergy 27: 671-693.

Vogt K.A., Andreu, M.G., Vogt, D.J., Sigurdardottir, R., Edmonds, R.L., Schiess, P., and Hodgson, K. 2005. Societal values and economic return added for forest owners by linking forests to bioenergy production. Journal of Forestry. January/February 2005: 2127.

Wooley, R., Ruth, M., Sheehan, J., Ibsen, K., Majdeski, H., Galvez, A., 1999. Lignocellulosic biomass to ethanol process design and economics utilizing co-current dilute acid 
prehydrolysis and enzymatic hydrolysis current and futuristic scenarios. National Renewable Energy Laboratory, Golden, Colorado. NREL/TP-580-26157.

Wang, J., Grushecky, S., and McNeel, J. 2006. Biomass Resources, Uses, and Opportunities in West Virginia. West Virginia University, Biomaterials Center, Morgantown, WV.

West Virginia Coal Association. 2007. West Virginia Coal Association releases 2007 coal facts. Available at http://www.wvcoal.com/news/news-archive/85-west-virginia-coalassociation-releases-2007-coal-facts.html. Last accessed March 26, 2009. 
CHAPTER 2: AN ECONOMIC ANALYSIS MODEL OF WOODY BIOMASS

UTILIZATION FOR BIOENERGY

\footnotetext{
${ }^{*}$ Submitted to Canadian Journal of Forest Research.
} 


\begin{abstract}
An economic model was developed to estimate the delivered cost of woody biomass which included the costs associated with biomass stumpage, harvesting/bundling, extraction, storage, loading and hauling, and chipping/grinding under different woody biomass handling systems. Seven woody biomass handling systems were considered based on extraction methods and forms of biomass delivered, including cable skidder-loose residue, cable skidder-chips, grapple skidder-loose residue, grapple skidder-chips, forwarder-loose residue, forwarder-chips, and forwarder-bundle. The model was designed to optimize a woody biomass-based biofuel facility's location with the objective of minimizing the total annual delivered cost of woody biomass under resource and operational constraints. The model was applied in the central Appalachian region within the state of West Virginia. Results showed that the optimal plant location would be at Addison (Forest District 3) in West Virginia when demand is 900 metric tons of dry woody biomass per day. For that base case scenario, the average delivered cost per unit of woody biomass ranged from $\$ 2.77 \mathrm{GJ}^{-1}$ to $\$ 3.01 \mathrm{GJ}^{-1}$ across the different handling systems. Extensive sensitivity analysis was performed under different resource and operational scenarios, such as woody biomass availability and purchase (stumpage) price, demand level, extraction distance, and fuel pricing. It was found that the delivered cost was mostly affected by woody biomass demand, mill residue availability, and mill residue purchase price. Skidding distance had the least impacts on the delivered cost. Due to the importance of the stabilization of the woody biomass supply chain, finding niche supply markets through long-term contracts or collaborative relationships with landowners and major forest products companies is recommended. The results would be useful to facilitate the research and economic development of woody biomass utilization for bioenergy in the region.
\end{abstract}




\subsection{Introduction}

Concerns about increasing volatility of crude oil prices, energy security, and environmental issues are driving the production and use of renewable energy in the United States. Woody biomass is a renewable energy source and can be used as feedstock for solid or liquid fuels or electricity generation (Kaylen et al. 2000, Bridgwater et al. 2002, Tembo et al. 2003, Thek and Obernberger 2004, Caputo et al. 2005). Wood-based biomass includes residues produced during timber harvesting, fuelwood extracted from forestlands, residues generated at primary and secondary wood processing facilities, and biomass from fuel reduction treatments (Wang et al. 2006). The delivered cost of woody biomass from forest to utilization plants includes the costs associated with a stumpage fee (if any), harvesting/bundling (if needed), extraction, storage, loading and hauling, chipping/grinding, and a return for profit and risk (Walsh et al. 1999). It varies spatially and is often the largest single cost component of a biomass derived fuel product (SRI 2007). Therefore, efficient harvesting, extraction, and transportation would be essential to the economic success of woody biomass utilization.

Woody biomass can be removed from the forest using different methods. Transporting loose residue, in-woods chipping, and bundling are all viable options (Spinelli et al. 2007). The collection of woody biomass can either be accomplished after harvesting activities or incorporated with the harvest of roundwood or other products. Woody biomass, in the form of branches, tops, etc. can be extracted to landings by a skidder or forwarder. The loose residue can then be delivered to consumers via truck or truck-and-trailer units. This system is constrained by the difficulty of fully utilizing vehicle payload and is preferable only over a short hauling distance (Spinelli et al. 2007). Chipping and grinding process can improve bulk volume, homogeneity, and handling characteristics of the raw material from forest (Johansson et al. 
2006). In-woods chipping as part of conventional logging or thinning is the most cost-effective system to recover forest residue for biomass (Hartsough et al. 1997). Bundling is a possible alternative to improve forest fuel-logistics (Spinelli et al. 2007). Biomass bundlers collect, compress, and bind forest residue into cylindrical bundles approximately 3 meters in length and between 0.6 and 0.8 meters in diameter (Rummer et al. 2004). The bundles can allow full load capacity if compression is enough and make handling, such as loading and processing, more efficient.

The total supply costs of various logging residue recovery systems have been studied extensively, especially in Scandinavian countries. Johansson et al. (2006) calculated the transport cost of fuel chips and bundles from stump to consumer and reported that bundles were cheaper to transport than fuel chips in road transport bins. Transportation cost was also affected by moisture content, which decreased until moisture content reached critical levels, below 40.9\% for chips and below $44.7 \%$ for bundles. Spinelli et al. (2007) simulated three logging residue recovery alternatives (in-woods chipping, bundling, and transporting loose residue) and identified the conditions that make one preferable to the others. The relationship between delivered cost and transportation distance showed that the bundling system was the least efficient option. Transporting loose residue was the cheapest alternative when the transportation distance was within $40 \mathrm{~km}$. Kärhä and Vartiamäki (2006) studied the supply costs of roadside chipping, loose residue, and standard bundling chains and derived similar results as Spinelli et al. (2007). If the bundling supply chain was optimized, it could be competitive with the loose residue supply chain when the transportation distance exceeded $60 \mathrm{~km}$.

Some efforts for estimating woody biomass delivered cost have been made in the U.S. (Kerstetter and Lyons 2001, Jensen et al. 2002, Grushecky et al. 2007, Pan et al. 2008, Galik et 
al. 2009). For example, Kerstetter and Lyons (2001) developed a logging residue supply curve for the U.S. Pacific Northwest, which can be used to derive the average cost of delivering a certain amount of logging residue to a specific location. They concluded that the in-woods cost of recovering logging residue was high, starting at $\$ 33$ per dry metric ton for the most accessible materials. Jensen et al. (2002) developed a program to estimate the cost of transporting residue on a county-by-county basis or a statewide basis. This program was specifically designed for mill residue, thus the costs associated with collection and handling of logging residue were not considered. Grushecky et al. (2007) estimated the costs of extraction and trucking of logging residue in West Virginia and found that the extraction and trucking cost ranged from $\$ 1.55 \mathrm{GJ}^{-1}$ to $\$ 5.09 \mathrm{GJ}^{-1}$ under different truck type and road conditions. Comparisons across studies are difficult because of differences in assumptions and methods. However, none of these studies considered both logging and mill residues as a biomass feedstock for biofuel plants, nor did they take into account optimization techniques to derive the supply cost of woody biomass and the logistics of woody biomass handling activities and working schedules.

The optimization of a woody biomass supply chain which involves all the handling activities as described above and is subject to supply and demand constraints can be realized through mathematical programming techniques. There are three types of static mathematical programming models including linear programming (LP), nonlinear programming (NLP), and integer or mixed integer programming (IP or MIP). Mixed integer optimization models have received increased attention in the area of forest logistics (Weintraub et al. 1994, 1995). MIP models have been used widely in many fields such as facility location, resources allocation, and scheduling problems (Mapemba 2005). Tembo et al. (2003) developed a multi-region, multiperiod MIP model encompassing alternative feedstock, feedstock production, delivery, and 
processing. The most economically efficient source of agriculture-based biomass, timing of harvest and storage, inventory management, and biorefinery size and location were determined in the model.

Located in the central Appalachian region, West Virginia (Figure 2.1) is the state with the third highest percentage of land area that is forested in the U.S. containing 4.8 million ha (12 million acres) of forest land (Griffith and Widmann 2003). The state produces 2.19 million dry metric tons of wood residues per year including 1.22 million dry metric tons of logging residue, 856,243 dry metric tons of mill residues, 107,809 dry metric tons of urban tree residues and 11,560 dry metric tons of pallet residues (Wang et al. 2006). Wood residues represent a significantly under-utilized source of biomass feedstock in the state, which could be used for biofuels production. However, industries that could use the woody biomass as feedstock for biofuels have limited information on potentials and economics of handling these biomass resources. This under-utilized resource has the potential to improve the economy of West Virginia. Given the fact that the median household income for West Virginia over the last three years was more than 25 percent lower than the national average (US Census Bureau 2008), this resource could play a major role in boosting the state economy. Therefore, the objectives of this paper were to: (1) develop an economic model to assess the cost of woody biomass utilization for bioenergy, and (2) apply the model in the central Appalachian region to facilitate rural economic development, and conduct sensitivity analyses under different resources and operational scenarios in the region. 


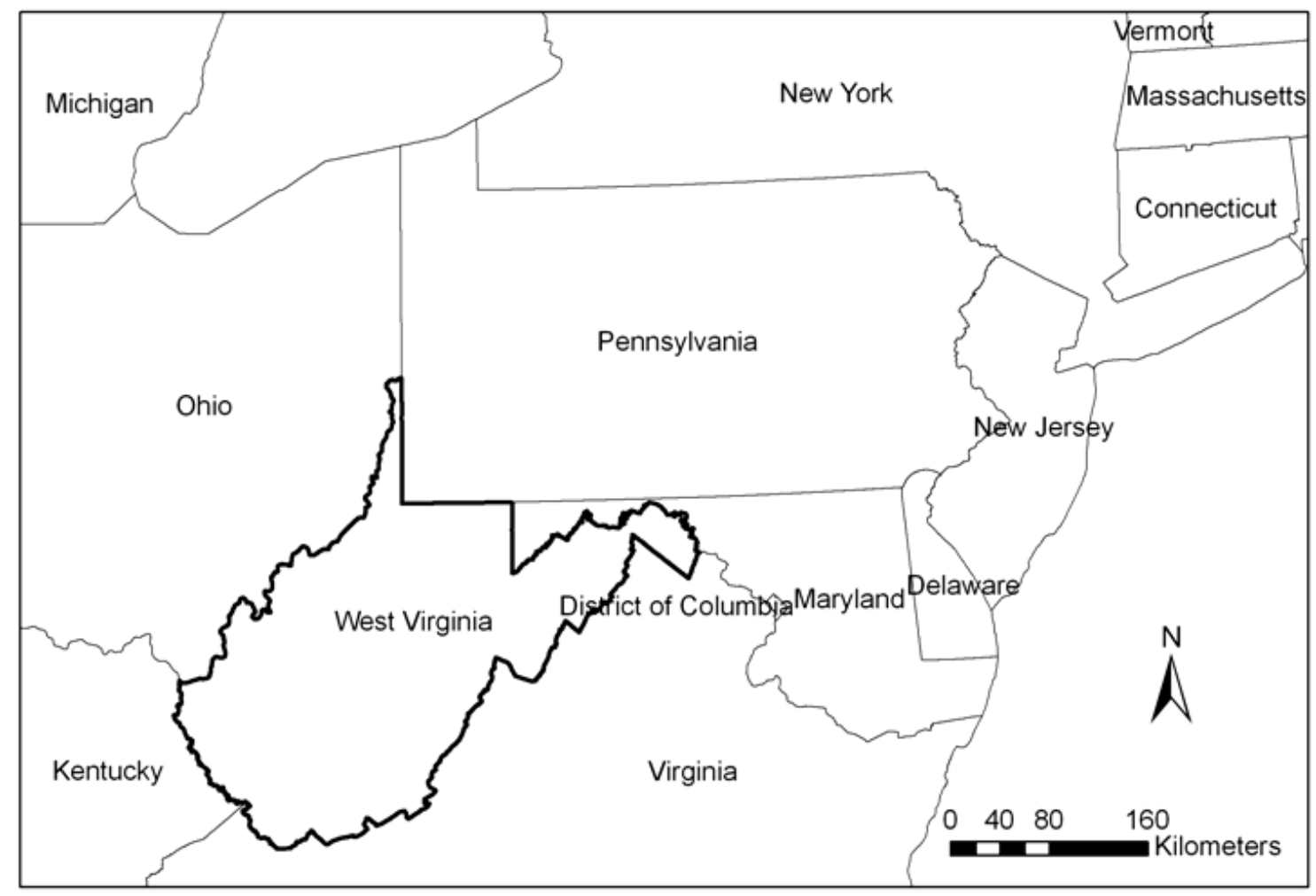

Figure 2.1. The geographical location of West Virginia, USA.

\subsection{Model Development}

\subsubsection{Objective Function}

A mixed integer programming (MIP) model was developed and solved using General Algebraic Modeling System (GAMS)/CPLEX. The objective of the MIP model was to minimize the total annual delivered cost of woody biomass from supply locations to demand locations, which was expressed as: 


$$
\begin{aligned}
\operatorname{Min} z= & \sum_{m=1}^{M}\left[\sum_{i=1}^{I} \sum_{h=1}^{H}\left(h c_{h}+b c_{h}+s p\right) \cdot x h_{i h m}+\sum_{i=1}^{I} \sum_{h=1}^{H} s c \cdot x p s_{i h m}+\sum_{i=1}^{I} \sum_{j=1}^{J} \sum_{h=1}^{H}\left(\tau_{i j h}+l c_{h}+c s_{h}+c p_{h}\right) \cdot x t_{i j h m}\right. \\
& \left.+\sum_{i=1}^{I} \sum_{j=1}^{J} \sum_{r=1}^{R}\left(m c_{r}+m t \cdot d_{i j}\right) \cdot x m_{i j r m}\right]+l c t
\end{aligned}
$$

The notations for variables and symbols in the model are explained in Appendix 2.A. The unit, metric ton, refers to green metric ton if not specified. The cost components considered in the objective function include a stumpage fee paid to land owners, logging residue harvesting/bundling (if any) and extraction, on-site storage, loading and hauling, in-woods chipping or grinding at a processing plant, and mill residue purchase and transportation.

Seven woody biomass handling systems that perform bundling (if any), extraction, storage, hauling, and chipping/grinding activities were included in the model based on extraction methods and forms of biomass delivered. These systems are cable skidder-loose residue (S1), cable skidder-chips (S2), grapple skidder-loose residue (S3), grapple skidder-chips (S4), forwarder-loose residue (S5), forwarder-chips (S6), and forwarder-bundle (S7). Except for the forwarder-bundle system, logging residues were assumed to be shipped out either immediately after collection or stored in the field for a period of time. It was assumed that there was one handling system employed at each supply location (Equation 2.2). The index of handling system $h$ ranges from 1 to 7 . To evaluate each system separately, the variable $\alpha_{i h}$ can be specified. For example, $\alpha_{i h}=1$ when $h=1$, which means that the handling system cable skidder-loose residue (S1) will be evaluated.

$$
\sum_{h=1}^{H} \alpha_{i h}=1, \quad \forall i
$$


The woody biomass was assumed to be delivered to one of the potential plant locations (Equation 2.3) at the minimum delivered cost. $\beta_{j}$ is a binary variable related to plant $j$. If $\beta_{j}$ equals 1 , woody biomass would be delivered to plant $j$, and 0 otherwise.

$$
\sum_{j=1}^{J} \beta_{j}=1
$$

The woody biomass supply locations were represented by counties in West Virginia. A city located near the geographic center of each county was used to represent the supply location for that county. The demand locations, or optional woody biomass-based utilization plants were selected based on a series of criteria depending on the types of the facilities. For instance, locating a woody biomass-based biorefinery may consider the proximity to feedstocks, utilities, infrastructure accessibility, and other factors.

Woody biomass transportation cost can be affected by hauling distance, fuel price, payload size, biomass dimension and density (loose residue, chips, bundles). The trucking cost component incorporating road networks was modeled based on the Wood Transportation and Resource Analysis System (WTRANS) (Jensen et al. 2002) and machine rate method (Miyata 1980) (Equation 2.4). The trucking cost per load from supply location $i$ to plant $j$ consists of fuel cost, driver wages, overhead and maintenance costs. In consideration of the different forms of woody biomass delivered (loose residues, wood chips, or bundles), the transportation cost rate $\left(\tau_{i j h}\right)$ associated with each woody biomass handling system was computed by dividing the total cost per truck load from supply location $i$ to plant $j\left(t_{i j}\right)$ by the weight hauled $\left(\right.$ load $\left._{h}\right)$ (Equation 2.5).

$$
t_{i j}=\frac{2 d_{i j}}{k p l} f p l+\frac{2 d_{i j}}{k p h} d w h+\frac{\frac{(t p-t s)}{n}+\left(\frac{(t p-t s)(n+1)}{2 n}+t s\right) i i t r}{s m h \cdot u t} \frac{2 d_{i j}}{k p h}+\frac{(t p-t s) m r}{n \cdot s m h \cdot u t} \frac{2 d_{i j}}{k p h}
$$




$$
\tau_{i j h}=\frac{t_{i j}}{\operatorname{load}_{h}}
$$

The variable lct is a cost component that is used to compute the under-estimated transportation cost (Equation 2.1). When the supply and demand locations are located in the same county or in adjacent counties, the assumed hauling distance of logging residue $d_{i j}$ could be less than the actual delivery distance, thus the total delivered cost of woody biomass could be underestimated. Transportation cost is related to the spatial distribution of logging residue. A mathematical model by Dornburg and Faaij (2001) was modified to determine lct. Assuming that the distribution of logging residue within a county was constant, expressed as biomass distribution density, the logging residue was transported over a marginal transport distance that was the radius of a circle in which the logging residue was spread within the given distribution density. Then we derive the total amount of ton- $\mathrm{km}$ to transport a certain amount of logging residue within a county:

$$
s m_{i}=\frac{2}{3}\left(\sum_{j=1}^{J} \sum_{h=1}^{H} \sum_{m=1}^{M} x t_{i j h m}\right)^{1.5}\left(D_{b} \pi\right)^{-0.5}, \forall i .
$$

Where, $s m_{i}$ is the average turnover (metric ton-km) for delivering biomass at supply location $i$, and $D_{b}$ is biomass spatial density (metric tons $\mathrm{km}^{-2}$ ). If we assumed one woody biomass handling system is used at one supply location (Equation 2.2) and one optimal plant location is selected (Equation 2.3), Equation (2.6) can be rewritten as:

$$
s m_{i}=\sum_{j=1}^{J} \sum_{h=1}^{H} \frac{2}{3}\left(\sum_{m=1}^{M} x t_{i j h m}\right)^{1.5}\left(D_{b} \pi\right)^{-0.5}, \forall i .
$$

The nonlinear function (Equation 2.7) was approximated by a piecewise linear function using the Separable Programming approach (Taha 2006). A finite number of breakpoints were 
defined over the entire range of the quantity of logging residue annually shipped out from the supply county $i$ by $a_{s}$, where $s=0,1, \cdots, S$. It is noted that as the number of breakpoints defined increases, the efficiency of the linear approximation will increase. However, the computation time will increase accordingly. Thus, a reasonable number of breakpoints should be used. Let $x t l_{i j h s}$ be the increment of annual amount of logging residue delivered from supply county $i$ to plant $j$ associated with system $h$ in the range $\left(a_{s-1}, a_{s}\right)$, and subject to the following constraints:

$$
\begin{gathered}
\sum_{s=1}^{S} x t l_{i j h s}=\sum_{m=1}^{M} x t_{i j h m}, \forall i, j, h . \\
0 \leq x t l_{i j h s} \leq a_{s}-a_{s-1}, s=1,2, \cdots, S
\end{gathered}
$$

So Equation (2.7) is transformed to:

$$
s m_{i}=\sum_{j=1}^{J} \sum_{h=1}^{H} \sum_{s=1}^{S} f c_{s} x t l_{i j h s}, \forall i
$$

Where, $f c_{s}$ is the slope of the $s^{\text {th }}$ line segment corresponding to $\frac{2}{3}\left(\sum_{m=1}^{M} x t_{i j h m}\right)^{1.5}\left(D_{b} \pi\right)^{-0.5}$.

Multiplying the average turnover $\left(s m_{i}\right)$ by the transportation cost rate $\left(t_{h}\right)$ for the different woody biomass handling systems and summing up all the counties together, the under-estimated transportation cost can be derived (Equation 2.11). A necessary constraint $\left(d_{i j} \leq r s_{i}\right)$ was set to ensure that the cost was only computed for the supply counties when the supply and demand locations are in the same county or adjacent counties.

$$
l c t=\sum_{i=1}^{I} \sum_{j=1}^{J} \sum_{h=1}^{H} \sum_{s=1}^{S} t_{h} f c_{s} x t l_{i j h s}, \text { where } d_{i j} \leq r s_{i}
$$




\subsubsection{Constraints}

The objective function (Equation 2.1) is also subject to a series of resource and operational constraints. The amount of logging residue annually extracted using system $h$ at supply location $i$ should be no greater than the available logging residue produced at that location (Equation 2.12). In terms of biomass accessibility, a terrain slope constraint was considered for the cable skidder, grapple skidder, and forwarder extraction systems to further limit logging residue availability. All the extraction machines and the slash bundler were assumed to be able to operate on forest sites with a slope of $35 \%$ or less. The amount of logging residue extracted was also subject to the availability of logging residue within a specific time period (or a month) (Equation 2.13) and extraction capability of local loggers (Equation 2.14). Wet or other extreme weather can limit loggers' ability to operate their harvesting equipment due to site accessibility safety and environmental concerns (Cusack 2008). There are certain times of the year when harvesting is limited due to wet or other extreme weather. An average rate of logging residue availability was evenly assigned for each month within a year. For instance, the logging residue extracted cannot be more than 1/12 of the total available amount if extracted in January. Then, this rate was adjusted based on historical production data and monthly precipitation in the study region. Local loggers' capability of extracting logging residue was defined by $\lambda p_{h} n l_{i} n m_{h}$.

Where, $\lambda$ is monthly productive time per machine in hours, $p_{h}$ is productivity of extraction machine associated with system $h, n l_{i}$ is the number of loggers in supply location $i$, and $n m_{h}$ is the average number of extraction machines that a logging crew owns.

$$
\left\{\begin{array}{l}
\sum_{m=1}^{M} x h_{i h m}-\alpha_{i h} b p_{i} b i v_{i} \leq 0, \quad \forall i, h . \\
\sum_{m=1}^{M} x h_{i h m}-\alpha_{i h} b p_{i} b v s_{i} \leq 0, \quad \forall i, h .
\end{array}\right.
$$




$$
\begin{aligned}
& \sum_{h=1}^{H} x h_{i h m}-e x t_{m} b p_{i} b v s_{i} \leq 0, \forall i, m . \\
& x h_{i h m}-\lambda p_{h} n l_{i} n m_{h} \leq 0, \forall i, h, m .
\end{aligned}
$$

Mill residue was considered to be another source of woody biomass for the plant, which would be delivered from mills to plant $j$ directly. The amount of mill residue shipped out of each location was also limited to the total mill residue available at that location (Equation 2.15).

$$
\sum_{j=1}^{J} x m_{i j r m}-m p_{i r} m i v_{i r} \leq 0, i, r, m
$$

Storage of logging residue at landings may occur when seasonal timber harvesting is conducted. The total logging residue extracted using system $h$ at supply location $i$ in month $m$ plus the usable portion of stored logging residue should balance with the sum of logging residue shipped to demand locations and stored in the field (Equation 2.16). For each supply county, the amount of biomass shipped out plus biomass lost in field storage should balance with the total biomass produced in a year (Tembo et al. 2003). The storage balance of logging residue for one year can be expressed as Equation (2.17).

$$
\begin{gathered}
x h_{i h m}+\theta_{i} x s_{i h m-1}-\sum_{j=1}^{J} x t_{i j h m}-x s_{i h m}=0, \quad \forall i, h, m . \\
\sum_{m=1}^{M} \sum_{h=1}^{H} x h_{i h m}+\theta_{i} \sum_{h=1}^{H} x s_{i h 12}+\left(\theta_{i}-1\right) \sum_{m=1}^{11} \sum_{h=1}^{H} x s_{i h m}-\sum_{h=1}^{H} x s_{i h 12}-\sum_{j=1}^{J} \sum_{h=1}^{H} \sum_{m=1}^{M} x t_{i j h m}=0, \quad \forall i .
\end{gathered}
$$

Rearranged Equation (2.17) as

$$
\sum_{m=1}^{M} \sum_{h=1}^{H} x h_{i h m}-\left(1-\theta_{i}\right) \sum_{m=1}^{M} \sum_{h=1}^{H} x s_{i h m}-\sum_{j=1}^{J} \sum_{h=1}^{H} \sum_{m=1}^{M} x t_{i j h m}=0, \quad \forall i .
$$

The interrelationship among logging residue extracted, logging residue entered into storage and removed from storage, and logging residue transported to demand locations is 
described in Equation (2.19), which is used to balance the whole logistics of the logging residue handling process.

$$
\sum_{h=1}^{H} x h_{i h m}-\sum_{h=1}^{H} x p s_{i h m}+\sum_{h=1}^{H} x s n_{i h m}-\sum_{h=1}^{H} \sum_{j=1}^{J} x t_{i j h m}=0, \forall i, m .
$$

Loose residue can either be shipped out immediately after collection or stored in the field for a period of time (Equation 2.20). Since it is not appropriate to store fresh wood chips at landings, the quantity of wood chips entered into onsite storage for the chipping systems (S2, S4, and S6) were assumed to be zero (Equation 2.20). Regarding the forwarder-bundle system (S7), slash bundles were assumed to be forwarded to a landing (storage site) for drying and transportation (Equation 2.20).

$$
\begin{cases}x p s_{i h m}-x h_{i h m} \leq 0, & \forall i, m, \text { where } h=1,3,5 \\ x s_{i h m}=0, & \forall i, m, \text { where } h=2,4,6 . \\ x p s_{i h m}-x h_{i h m}=0, & \forall i, m, \text { where } h=7 .\end{cases}
$$

The total woody biomass delivered to a plant plus the usable biomass stored in the previous month at the plant should balance with the storage and feedstock processed at the plant for the current month (Equation 2.21). The moisture content of logging residue $(\operatorname{lmc})$ and mill residue $\left(m m c_{r}\right)$ would be specified for the study region.

$$
\sum_{i=1}^{I} \sum_{h=1}^{H}(1-\delta)(1-l m c) x t_{i j h m}+\sum_{i=1}^{I} \sum_{r=1}^{R}\left(1-m m c_{r}\right) x m_{i j r m}+\phi x s s_{j m-1}-x s s_{j m}-x p p_{j m}=0, \forall j, m
$$

The quantity of woody biomass processed each month was subject to the monthly feedstock demand at a plant (Equation 2.22). The feedstock needed for plant $j$ per month was $\rho \cdot$ capacity $\cdot \beta_{j}$. If $\beta_{j}=1, x p p_{j m}=\rho \cdot$ capacity, otherwise the processing capacity at plant $j$ would be zero.

$$
x p p_{j m}-\rho \cdot \text { capacity } \cdot \beta_{j}=0, \forall j, m \text {. }
$$


The minimum inventory of woody biomass at a plant was defined to ensure uninterrupted production as Mapemba (2005) described, and zero inventories were assumed in the model.

$$
x S s_{j m}-\operatorname{mnbin} \cdot \beta_{j} \geq 0, \forall j, m .
$$

Finally, the following decision variables should be nonnegative

$$
x h_{i h m}, x t_{i j h m}, x m_{i j r m}, x s_{i h m}, x p s_{i h m}, x s n_{i h m}, x s s_{j m}, x p p_{j m} \geq 0
$$

\subsection{Model Application}

The model was applied in the central Appalachian region within the state of West Virginia. Approximately 68 percent of mill residue was utilized in 2006, and most of the logging residue, which makes up the largest proportion of wood residue, was underutilized according to Wang et al. (2006). The utilization of abundant wood residue as feedstock for ethanol or other biofuels or bio-products may provide West Virginia a significant opportunity in economic development and energy independence. All the counties in West Virginia were chosen as potential woody biomass supply locations (Figure 2.2a). Six woody biomass demand locations were selected, one for each forest district in West Virginia (Figure 2.2b). A medium size bioenergy plant with a demand of 900 metric tons of dry woody biomass per day, combined with the following assumptions was used as the base case for assessing the delivered cost of woody biomass. 


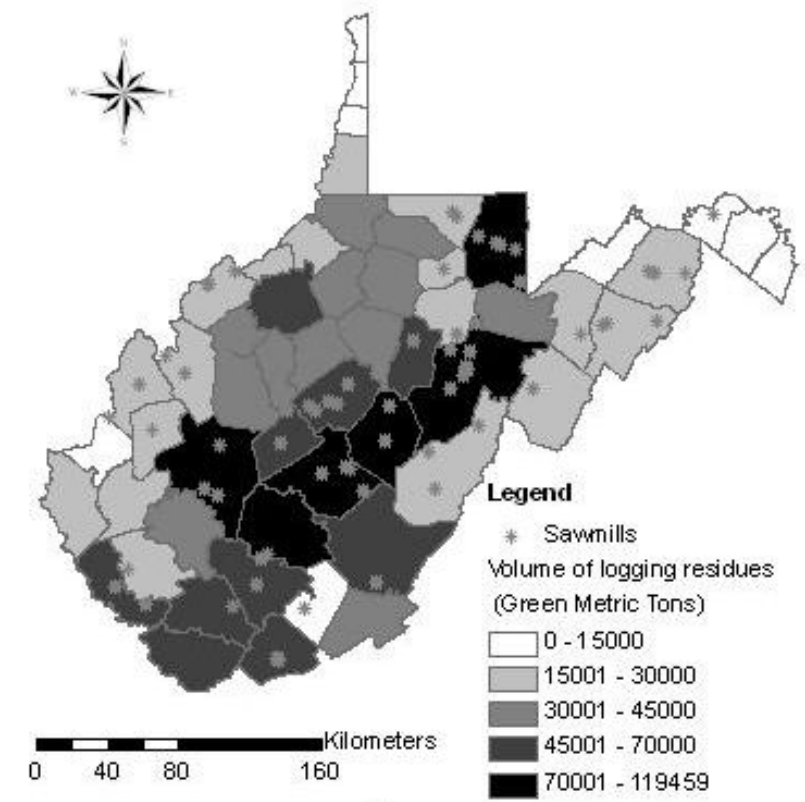

(a)

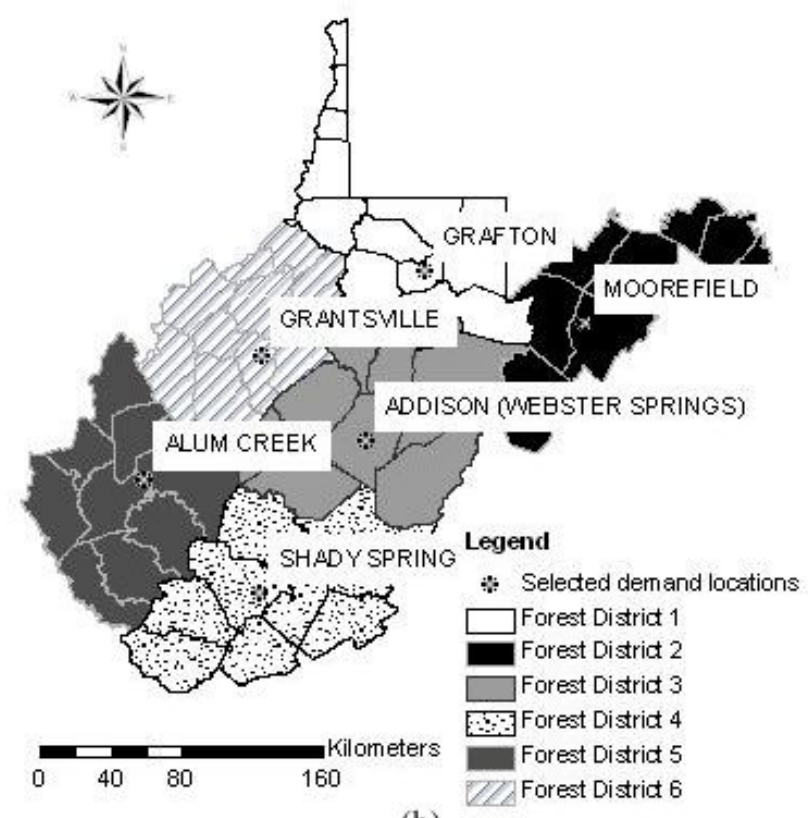

(b)

Figure 2.2. Modeled woody biomass supply and demand locations in West Virginia. (a) Annual logging residue production and mill residue distribution. (b) Selected woody biomass demand locations.

\subsubsection{Woody Biomass Availability and Accessibility}

The production of wood residues has been surveyed several times over the last 10 years in West Virginia (Wang et al. 2006). The annual harvested acreage was obtained from the West Virginia Logging Sediment Control Act (LSCA) 2006 statistics (WVDOF 2006). The annual harvested acreage averaged approximately 100,000 ha (250,000 acres) over the last 10 years, which is about two percent of the total forest land in the state. The amount of logging residue in each county was derived by multiplying the harvested acres by the logging residue density from previous surveys (Grushecky et al. 2006). Subject to the operational accessibility, harvesting techniques, economic and environmental constraints, the recovery rate of logging residues was assumed to be 65 percent on the forest lands with a slope of 35 percent or less. The availability of logging residue by month in percent was assumed as $\operatorname{ext}_{m}=\{8.3,8.3,8.3,8.3,7.5,7.5,7.5$, 
$7.5,9.2,9.2,9.2,9.2\}$ based on the harvesting time and monthly precipitation in West Virginia (USDS 2009).

Logging residue has been promoted as an under-utilized resource with limited value and a stumpage price of $\$ 1$ metric ton $^{-1}$ was assumed for logging residue in the study (Galik et al. 2009). Data from an annual report by the West Virginia University Appalachian Hardwood Center (Bragonje et al. 2006) were used to estimate the annual production of mill residue in the region. Forty percent of mill residue in the supply counties was assumed to be available at an average cost of $\$ 25$ metric ton ${ }^{-1}$ for bark and chips, $\$ 30$ metric ton ${ }^{-1}$ for sawdust, $\$ 20$ metric ton $^{-1}$ for slabs and planer shavings, and $\$ 10$ metric ton $^{-1}$ for other mill residues (T. Goff, personal communication, 2009). Feedstock competition from other uses (such as pellet fuel, boiler fuel, paper, charcoal, and others) was also considered in the cost estimate process. The usable proportions of logging residue stored at landings and at plants were assumed to be $95 \%$ and $99 \%$, respectively (Richardson et al. 2002). The average moisture content of logging residue was assumed at 43 percent (wet basis) while the moisture content of mill residue was assumed as 30 percent for sawdust and chips, 20 percent for planer shavings, and 42 percent for bark, slabs and others (Wang et al. 2006). Hardwood logging residue density was 0.77 metric ton $\mathrm{m}^{-3}\left(47.8 \mathrm{lb} \mathrm{ft}^{-}\right.$ ${ }^{3}$ ) (Appalachian Hardwood Center 2006).

The number of licensed loggers in each county was obtained from the West Virginia Division of Forestry. A logging firm in the state owns, on average, 1.5 cable skidders and 1.6 grapple skidders (Milauskas and Wang 2006). Forwarders are not as commonly used as cable and grapple skidders in this region. We assumed the average number of forwarders per firm to be one. The productive time of each extraction machine was assumed to be 6 hours per day and 5 days a week. Therefore, there would be a total of 120 productive hours per machine in a month. 
It was assumed that there were enough transportation vehicles to deliver woody biomass from stands (or mills) to a woody biomass-based plant in the study region.

\subsubsection{Logging Residue Handling Productivities and Costs}

The assumptions for the woody biomass handling machines were presented in Table 2.1. Hourly machine costs were calculated by using the machine rate method (Miyata 1980), which includes fixed or ownership costs, variable or operating costs, and labor costs (Table 2.2). The productivities of woody biomass extraction by the cable skidder, grapple skidder, and forwarder were calculated using the existing models developed in the region (Wang et al. 2004, Li et al. 2006, Grushecky et al. 2007). Average extraction distance of logging residues was assumed as $300 \mathrm{~m}$ for all systems (Li et al. 2006). The payload size was $3 \mathrm{~m}^{3}$ for the cable skidder, $3.05 \mathrm{~m}^{3}$ for the grapple skidder, $8.5 \mathrm{~m}^{3}$ for the forwarder (loose residue), and $12 \mathrm{~m}^{3}$ for the forwarder (bundles) (Rummer et al. 2004; Grushecky et al. 2007). Loading productivity varied among different products: $15.30 \mathrm{~m}^{3} \mathrm{~h}^{-1}$ for loading pulp logs, $34.02 \mathrm{~m}^{3} \mathrm{~h}^{-1}$ for peeler logs, and $55.08 \mathrm{~m}^{3}$ $\mathrm{h}^{-1}$ for sawlogs in West Virginia (Wang 2007). The models developed by Wang (2007) were employed to estimate loading productivity for forest slash bundles and residues in consideration of the physical properties (length, diameter, and weight). The productivities for other machines were based on literature (Leinonen 2004, Kärhä and Vartiamäki 2006). The unit cost for each individual handling machine was computed by dividing hourly machine cost by hourly production rate (Table 2.2).

Tractor-trailers, quad bunk short-log trailers, and chip vans were used for transporting loose residue, slash bundles, and chips, respectively. Fuel consumption was assumed to be 2.12 $\mathrm{km} \mathrm{l}^{-1}$ on average and the average speed of a fully loaded vehicle was $56.32 \mathrm{~km} \mathrm{~h}^{-1}$ for intercounty transportation and $40.23 \mathrm{~km} \mathrm{~h}^{-1}$ for intra-county transportation (M. Adams, personal 
communication, 2008). The maximum loaded capacity of the truck and chip van was limited by legislation in West Virginia and the vehicle capacity, assumed as 23 metric tons. Considering the density and form of woody biomass, the loaded capacity (wet basis) was assumed as: 12.73 metric tons for loose residue, 19.09 metric tons for chips, and 18.18 metric tons for forest slash bundles (Spinelli et al. 2007). Hauling distances between the supply and plant locations were determined using the ArcGIS Network Analyst, Origin-Destination (OD) cost matrix. The detailed street dataset was from the 2003 Tele Atlas Dynamap Transportation version 5.2 product. An Excel spreadsheet was used to store the $55 \times 6$ distance matrix and was called by the GAMS program when implemented.

Table 2.1. Assumptions for the woody biomass handling machines ${ }^{\mathrm{a}}$.

\begin{tabular}{|c|c|c|c|c|c|c|c|c|c|c|}
\hline Items & $\mathrm{CD}$ & GD & FL & FB & SD & LD & $\mathrm{CP}$ & GL & GB & $\mathrm{HV}$ \\
\hline $\begin{array}{l}\text { Purchase price } \\
(\$ 1,000)\end{array}$ & 130 & 200 & 265 & 310 & 450 & 150 & 330 & 350 & 350 & 140 \\
\hline $\begin{array}{l}\text { Salvage value (\% of } \\
\text { price) })^{b}\end{array}$ & 20 & 25 & 20 & 20 & 20 & 30 & 20 & 20 & 20 & 20 \\
\hline Economic life $(\mathrm{yr})^{b}$ & 5 & 5 & 5 & 5 & 5 & 5 & 5 & 5 & 5 & 8 \\
\hline $\begin{array}{l}\text { Interest, insurance, } \\
\text { and tax }(\%)^{c, d},\end{array}$ & 20 & 20 & 20 & 20 & 20 & 20 & 20 & 20 & 20 & 20 \\
\hline Labor cost $\left(\$ h^{-1}\right)^{c}$ & 10 & 10 & 10 & 10 & 10 & 10 & 10 & 10 & 10 & 10 \\
\hline $\begin{array}{l}\text { Labor fringe ( } \% \text { of } \\
\text { labor cost) }^{c}\end{array}$ & 35 & 35 & 35 & 35 & 35 & 35 & 35 & 35 & 35 & 40 \\
\hline $\begin{array}{l}\text { Maintenance and } \\
\text { repair (\% of } \\
\text { depreciation) })^{c, d}\end{array}$ & 90 & 90 & 90 & 90 & 90 & 90 & 90 & 90 & 90 & 90 \\
\hline $\begin{array}{l}\text { Mechanical } \\
\text { availability }(\%)^{b}\end{array}$ & 65 & 65 & 65 & 65 & 65 & 65 & 75 & 80 & 80 & 90 \\
\hline Horse power (hp) & 117 & 117 & 115 & 161 & 182 & 170 & 500 & 700 & 875 & - \\
\hline Fuel price $\left(\left(\$ 1^{-1}\right)\right.$ & 0.94 & 0.94 & 0.94 & 0.94 & 0.94 & 0.94 & 0.94 & 0.94 & 0.94 & 0.94 \\
\hline $\begin{array}{l}\text { Fuel consumption (1 } \\
\left.\mathrm{hp}^{-1} \mathrm{~h}^{-1}\right)^{b}\end{array}$ & 0.11 & 0.11 & 0.09 & 0.09 & 0.12 & 0.08 & 0.11 & 0.11 & 0.11 & - \\
\hline $\begin{array}{l}\text { Lube and oil (\% of } \\
\text { fuel cost) }\end{array}$ & 36.7 & 36.7 & 36.7 & 36.7 & 36.7 & 36.7 & 36.7 & 36.7 & 36.7 & - \\
\hline $\begin{array}{l}\text { Scheduled machine } \\
\text { hour }\left(\mathrm{h} \mathrm{yr}^{-1}\right)^{\mathrm{c}, \mathrm{d}}\end{array}$ & 2,000 & 2,000 & 2,000 & 2,000 & 2,000 & 2,000 & 2,000 & 2,000 & 2,000 & 2,000 \\
\hline
\end{tabular}


Table 2.2. Cost calculations for the different handling machines.

\begin{tabular}{lccc}
\hline Machine $^{a}$ & Hourly cost $\left(\$ \mathrm{~h}^{-1}\right)$ & Productivity $\left(\mathrm{t} \mathrm{h}^{-1}\right)^{b}$ & Cost $\left(\$ \mathrm{t}^{-1}\right)^{b}$ \\
\hline CD & 81.34 & 6.34 & 12.83 \\
GD & 102.72 & 11.46 & 8.96 \\
FL & 124.35 & 12.71 & 9.78 \\
FB & 145.14 & $20.74^{c}$ & 7.00 \\
SD & $205.51^{d}$ & $13.00^{e}$ & 15.81 \\
LD & 85.96 & 16.04 & 5.36 \\
CP & 185.62 & $30.00^{f}$ & 6.19 \\
GL & 212.27 & $91.00^{f}$ & 2.33 \\
GB & 237.05 & $120.00^{f}$ & 1.98 \\
\hline
\end{tabular}

\footnotetext{
${ }^{a}$ CD-cable skidder, GD-grapple skidder, FL-forwarder (forwarding loose residue), FB-forwarder (forwarding bundles), SD-slash bundler, LD-loader, CP-chipper, GL-grinder (loose residue), GB-grinder (bundles).

${ }^{b}$ Wet basis.

${ }^{c}$ Kärhä and Vartiamäki (2006).

${ }^{d}$ Baling twine cost which was estimated at $5 \$ \mathrm{~h}^{-1}$ given the productivity of 20 bundles $\mathrm{h}^{-1}$ was included (Rummer et al. 2004).

${ }^{e}$ Rummer et al. (2004).

${ }^{f}$ Leinonen (2004).
}

\subsection{Results}

\subsubsection{Base Case}

The optimization of a biomass-based plant with a demand of 900 metric tons of dry woody biomass per day was summarized in terms of delivered cost, average hauling distance, and optimal plant location by the woody biomass handling systems (Table 2.3). The optimal biomass-based plant was located approximately at Addison (Forest District 3) in West Virginia. The grapple skidder-loose residue system (S3) was the most cost-effective with delivered cost of $\$ 2.77 \mathrm{GJ}^{-1}$, while the forwarder-bundle system (S7) was the most expensive across the handling systems with delivered cost of $\$ 3.01 \mathrm{GJ}^{-1}$. As the procurement distance increased, the average delivered cost of woody biomass increased. Equations (2.25) and (2.26) were used to compute the average hauling or procurement distance for logging residue and mill residue, respectively. Results showed that the average delivery distance for mill residue was farther than that of logging residue across the systems. 
Table 2.3. Optimization summary of woody biomass handling by system in the base case.

\begin{tabular}{|c|c|c|c|c|c|c|}
\hline System $^{a}$ & $\begin{array}{c}\text { Average } \\
\text { delivered cost }\end{array}$ & $\begin{array}{l}\text { Logging } \\
\text { residue } \\
\text { delivered } \operatorname{cost}^{b}\end{array}$ & $\begin{array}{c}\text { Mill residue } \\
\text { delivered } \\
\text { cost }^{b}\end{array}$ & $\begin{array}{l}\text { Logging } \\
\text { residue } \\
\text { hauling } \\
\text { distance }^{c}\end{array}$ & $\begin{array}{l}\text { Mill residue } \\
\text { hauling } \\
\text { distance }^{c}\end{array}$ & $\begin{array}{l}\text { Optimal } \\
\text { plant } \\
\text { location }\end{array}$ \\
\hline S1 & 2.93 & 3.06 & 2.89 & 38.06 & 62.65 & $\begin{array}{c}\text { Forest } \\
\text { District } 3\end{array}$ \\
\hline S2 & 2.98 & 3.26 & 2.89 & 38.06 & 62.65 & $\begin{array}{c}\text { Forest } \\
\text { District } 3\end{array}$ \\
\hline S3 & 2.77 & 2.79 & 2.76 & 47.34 & 56.90 & $\begin{array}{c}\text { Forest } \\
\text { District } 3\end{array}$ \\
\hline S4 & 2.83 & 2.93 & 2.76 & 47.22 & 56.98 & $\begin{array}{c}\text { Forest } \\
\text { District } 3\end{array}$ \\
\hline S5 & 2.81 & 2.88 & 2.77 & 46.92 & 57.36 & $\begin{array}{c}\text { Forest } \\
\text { District } 3\end{array}$ \\
\hline S6 & 2.87 & 3.02 & 2.77 & 46.62 & 57.85 & $\begin{array}{c}\text { Forest } \\
\text { District } 3\end{array}$ \\
\hline S7 & 3.01 & 3.32 & 2.93 & 33.37 & 63.09 & $\begin{array}{c}\text { Forest } \\
\text { District } 3\end{array}$ \\
\hline
\end{tabular}

${ }^{a}$ S1-cable skidder-loose residue, S2-cable skidder-chips, S3-grapple skidder-loose residue, S4-grapple skidder-chips, S5-forwarder-loose residue, S6-forwarder-chips, and S7-forwarder-bundle.

${ }^{b}$ Unit: $\$ \mathrm{GJ}^{-1}$. Woody biomass: $1 \mathrm{t}=17.48 \mathrm{GJ}$.

${ }^{c}$ Unit: km.

$$
\begin{aligned}
& \text { distl }=\sum_{i=1}^{I} \sum_{j=1}^{J} \sum_{h=1}^{H} \sum_{m=1}^{M} d_{i j} x t_{i j h m} / \sum_{i=1}^{I} \sum_{j=1}^{J} \sum_{h=1}^{H} \sum_{m=1}^{M} x t_{i j h m} \\
& \text { distm }=\sum_{i=1}^{I} \sum_{j=1}^{J} \sum_{r=1}^{R} \sum_{m=1}^{M} d_{i j} x m_{i j r m} / \sum_{i=1}^{I} \sum_{j=1}^{J} \sum_{r=1}^{R} \sum_{m=1}^{M} x m_{i j r m}
\end{aligned}
$$

The quantity of woody biomass delivered per year was examined for each woody biomass handling system (Figure 2.3). Logging residue accounted for 19 (S7) to 40 (S3, S4, S5, S6) percent of the total woody biomass delivered while the rest was mill residue. Systems 1, 2, and 7 were heavily dependent on mill residue, thus may face competition from current users and prospective utilization. The quantity of woody biomass delivered in each month can also be examined by the handling system. For the most cost effective grapple skidder-loose residue system (S3), the proportion of logging residue delivered changed from 41 percent to 39 percent from the period of January-April to May-August and then increased to 43 percent until 
December. These changes could be attributed to the difference of monthly availability of logging residue, seasonal work days, precipitation, and other factors.

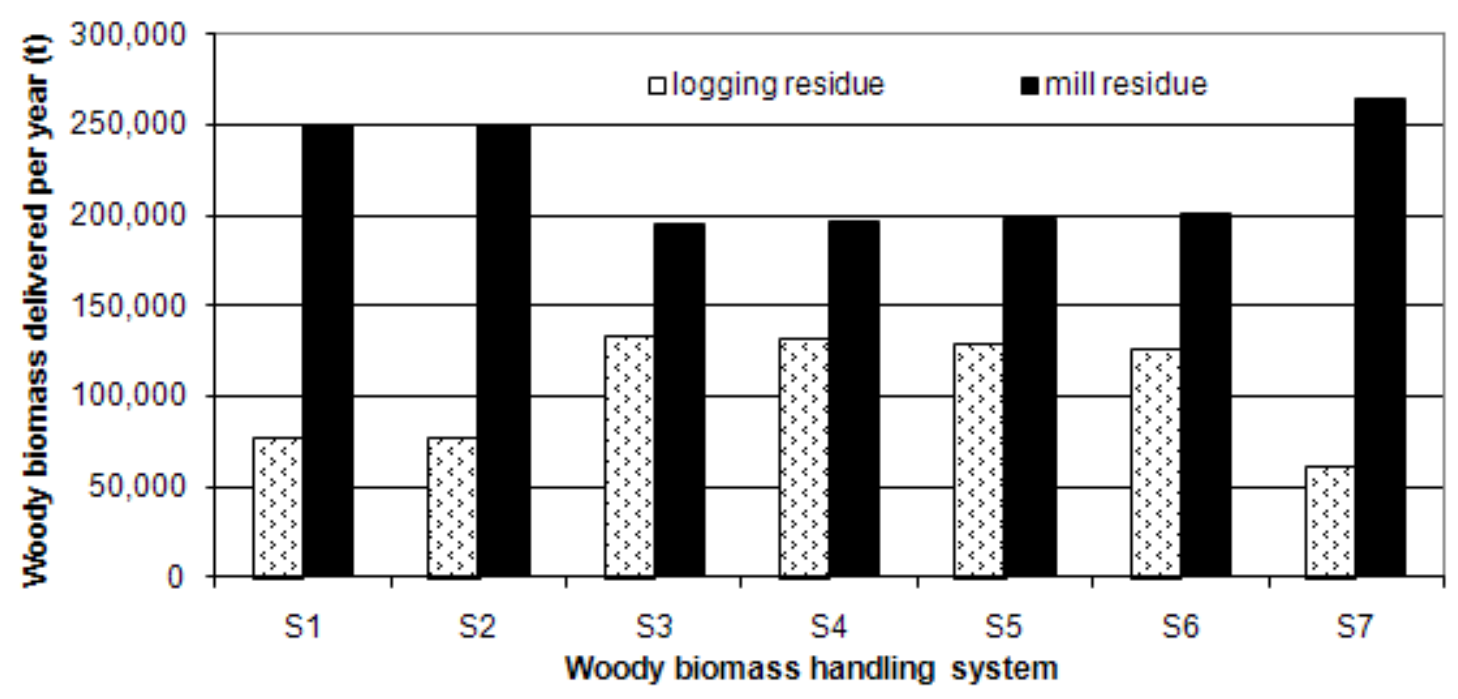

Figure 2.3. Woody biomass delivered per year by handling system (dry weight).

The delivered cost of logging residue included the costs associated with stumpage, bundling (if any), extraction, storage (if any), loading and hauling, and chipping/grinding. Extraction and transportation were the major cost components for systems S1-S6, accounting for an average of 39 percent and 22 percent of the total delivered cost, respectively, which were followed by chipping/grinding and loading (Figure 2.4). For the forwarder-bundle system (S7), bundling was the major cost component and accounted for 53 percent of the total delivered cost. It was followed by extraction ( 25 percent), transportation (13 percent), grinding ( 7 percent) and stumpage ( 3 percent). The comparisons among the handling systems for the base case indicated that delivering loose logging residue was much cheaper than shipping chips to the optimal plant. No storage cost was incurred in any of the systems. Since timber harvesting takes place all year round in West Virginia, logging residue is accordingly available and ready for collection for the whole year. Typically, there is no need to store logging residue at landings or roadside. Onsite 
storage without cost incurs in system 7 because slash bundles extracted were assumed to be entered into storage for drying.

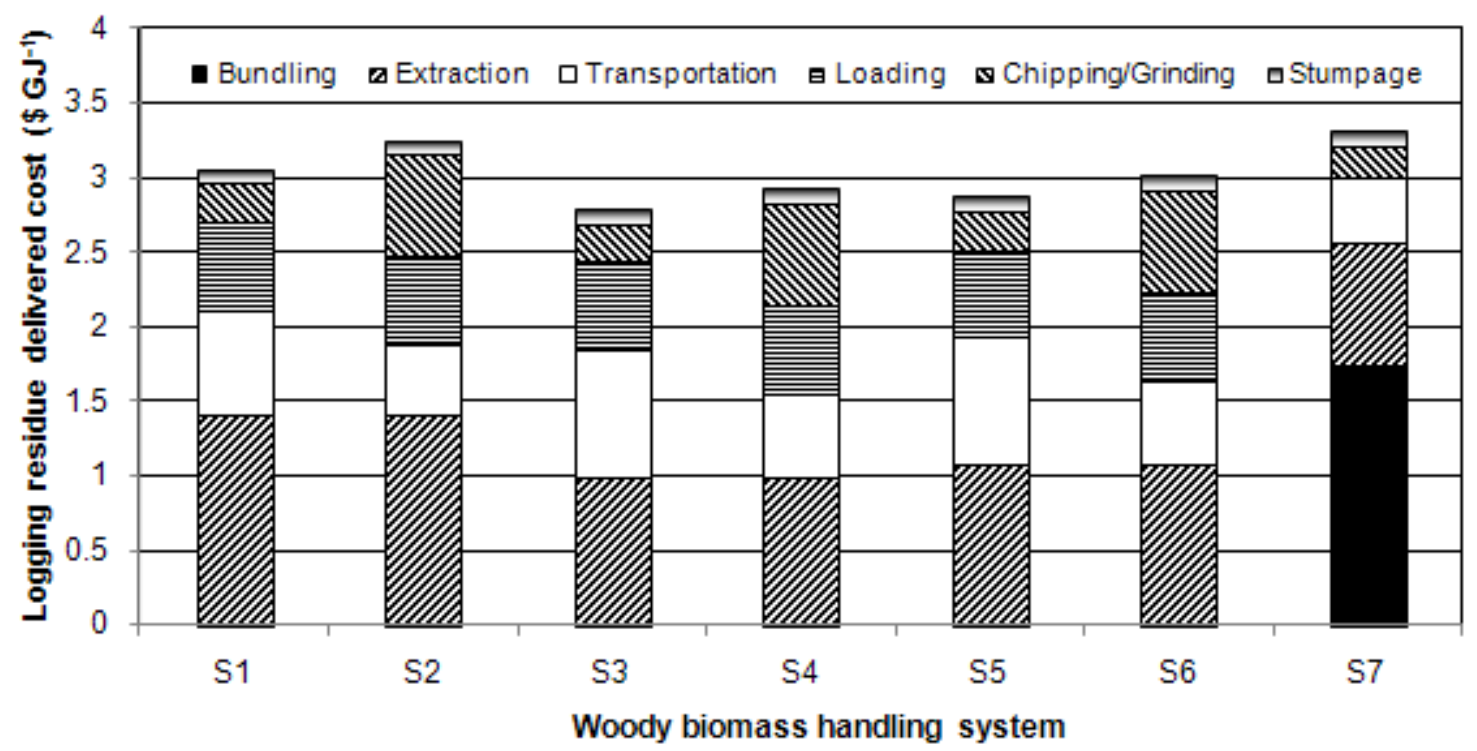

Figure 2.4. Delivered cost composition of logging residue by woody biomass handling system for the base case.

The delivered cost per unit of mill residue averaged $\$ 2.83 \mathrm{GJ}^{-1}$ and varied slightly among the different woody biomass handling systems. Purchase cost was the largest component and accounted for approximately 79 percent of the total mill residue delivered cost, followed by transportation cost (21 percent). In general, the delivered cost of woody biomass was higher than that of coal $\left(\$ 2.50 \mathrm{GJ}^{-1}\right)$ (US EIA 2010) and switchgrass $\left(\$ 1.84-2.37 \mathrm{GJ}^{-1}\right)($ Kumar and Sokhansanj 2007).

\subsubsection{Sensitivity Analyses}

(1) Woody Biomass Availability

A decrease in logging residue availability would increase the delivered cost of woody biomass due primarily to longer hauling distances (Figure 2.5a). Compared to the base case with 65 percent of logging residue available, if the availability of logging residue was down to 30 
percent, the delivered cost would increase 2 percent $\left(\$ 0.05 \mathrm{GJ}^{-1}\right)$ for the cable skidder-loose residue system, 1 percent $\left(\$ 0.03 \mathrm{GJ}^{-1}\right)$ for the cable skidder-chips system, 4 percent $\left(\$ 0.10 \mathrm{GJ}^{-1}\right)$ for the grapple skidder-loose residue system, 3 percent $\left(\$ 0.07 \mathrm{GJ}^{-1}\right)$ for the grapple skidderchips system, 3 percent $\left(\$ 0.09 \mathrm{GJ}^{-1}\right)$ for the forwarder-loose residue system, 2 percent $\left(\$ 0.06 \mathrm{GJ}^{-}\right.$ ${ }^{1}$ ) for the forwarder-chips system, and 1 percent $\left(\$ 0.03 \mathrm{GJ}^{-1}\right)$ for the forwarder-bundle system. Efficient harvesting such as collecting logging residue during timber harvesting is critical to the future economic viability of logging residue utilization (Grushecky et al. 2007). However, the implications of increased harvest efficiency must be weighed against potential impacts on site productivity, especially for low-productivity sites (Scott and Dean 2006).

As a byproduct, mill residue is limited by production constraints in sawmills. The utilization of mill residue for biofuels will compete with other established uses such as pellet fuel, boiler fuel, and others in the central Appalachian region. If the mill residue availability changed from 40 percent (base case) to 20 percent, the delivered cost would increase 9 percent for the cable skidder systems (S1 and S2), 6 percent for the grapple skidder systems (S3 and S4) and the forwarder systems (S5 and S6), and 10 percent for the forwarder-bundle system (S7) (Figure 2.5b). 

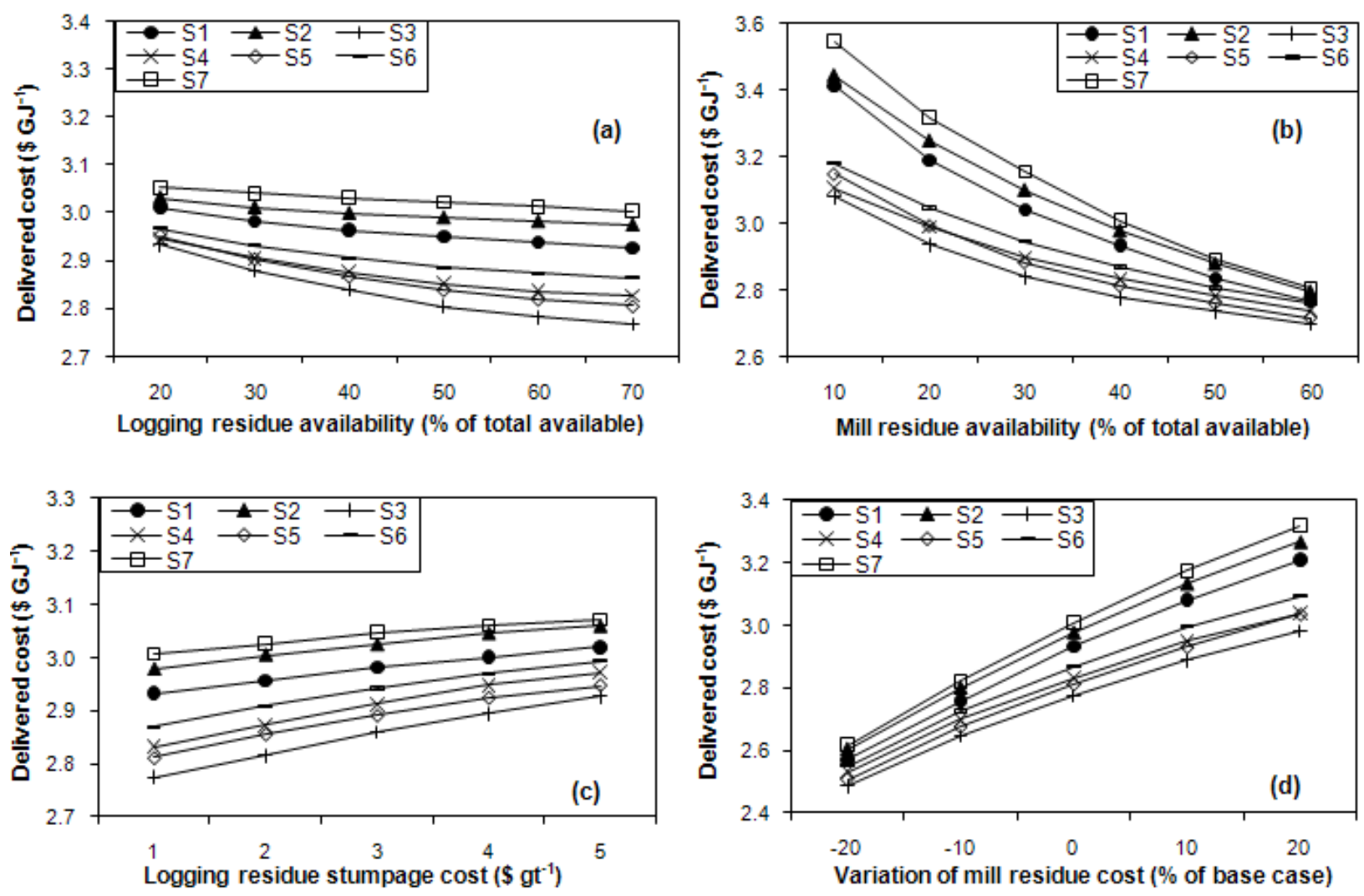

Figure 2.5. Sensitivity analyses of the woody biomass delivered cost by residue availability and purchase cost ( $1 \mathrm{gt}=1$ green metric ton).

\section{(2) Woody Biomass Purchase Price}

At current market price, the value of uncollected logging residue is very low. Therefore, a stumpage price of $\$ 1$ metric ton ${ }^{-1}$ was assumed for logging residue in the base case. As the market for biomass develops, more biomass will be needed and forest land owners may expect a higher return for these raw materials. The delivered cost would increase $\$ 0.01-\$ 0.04 \mathrm{GJ}^{-1}$ as a result of every one dollar per green ton increase in the stumpage cost of logging residue (Figure 2.5c). The purchase price of mill residue was based on current market pricing in the region. Mill residue has been traditionally used as pellet and boiler fuels in the region. The potential competition between current uses and prospective utilization for biofuels could raise the price of mill residue, especially when they are in high demand. Sensitivity analysis indicated how the 
variation of mill residue purchase price affected the delivered cost of mill residue (Figure 2.5d). Increasing the purchase price of mill residue by 10 percent would cause an increase of delivered cost by 5 percent for the cable skidder systems (S1 and S2), 4 percent for the grapple skidder and forwarder systems (S3-S6), and 6 percent for the forwarder-bundle system (S7).

(3) Woody Biomass Supplied

The average delivered cost increased dramatically for all systems as the supply of woody biomass to the plant increased (Figure 2.6a). The grapple skidder-loose residue system (S3) presented the lowest procurement cost while the forwarder-bundle handling system (S7) was the most expensive system at different supply levels of woody biomass. The delivered cost of woody biomass would increase 3 percent, 6 percent, and 10 percent on average compared to the base case if the supply increased 200 dry metric tons day ${ }^{-1}, 400$ dry metric tons day $^{-1}$, and 600 dry

metric tons day ${ }^{-1}$, respectively. The supply of biomass is constrained by the availability of known forest resources in the region. Considering the defined biomass resource constraints (65 percent of availability for logging residue and 40 percent for mill residue), slope constraints for extraction operations, and the current harvesting rate in West Virginia, the available wood residues could sustainably supply one woody biomass-based plant with capacity up to 2,400 dry metric tons per day. Other biomass resources such as roundwood or other non-forest biomass need to be utilized to meet demand above that level.

(4) Logging Residue Skidding Distance

The productivity of extraction machines (i.e., cable skidder, grapple skidder, and forwarder) generally decreased as the skidding distance increased, and the extraction cost would increase accordingly ( $\mathrm{Li}$ et al. 2006). The delivered cost of woody biomass increased as the extraction distance increased (Figure 2.6b). The sensitivity analysis showed that the delivered 
cost would increase $\$ 0.002-\$ 0.100 \mathrm{GJ}^{-1}$ for every $30 \mathrm{~m}$ (approximately 100 feet) skidding distance increase depending on the system used. The forwarder-bundle system (S7) resulted in the highest delivered cost, followed by the cable skidder systems (S1 and S2). Pan et al. (2008) suggested that shortening skidding distance and balancing other additional costs (i.e., hauling, building landings) should be factored in harvest planning.

(5) Fuel Price

Fuel (diesel) prices increased to historically high levels, increasing from $\$ 0.661^{-1}(\$ 2.51$ gallon $^{-1}$ ) in Feb. 2007 to $\$ 1.231^{-1}$ (\$4.66 gallon $^{-1}$ ) in July 2008 (U.S. Energy Information Administration 2008). The woody biomass extraction machines (skidders and forwarders), loaders, slash bundlers, chipper/grinders, and transportation vehicles typically use diesel fuel. The delivered cost of woody biomass generally increased as the fuel price increased (Figure 2.6c). For every $\$ 0.10 \mathrm{l}^{-1}$ increase in diesel price, the delivered cost would increase $\$ 0.041 \mathrm{GJ}^{-1}$ for the cable skidder-loose residue system, $\$ 0.042 \mathrm{GJ}^{-1}$ for the cable skidder-chips system, $\$ 0.046 \mathrm{GJ}^{-1}$ for the grapple skidder-loose residue system, $\$ 0.0 .047 \mathrm{GJ}^{-1}$ for the grapple skidderchips system, $\$ 0.044 \mathrm{GJ}^{-1}$ for the forwarder-loose residue system, $\$ 0.045 \mathrm{GJ}^{-1}$ for the forwarderchips system, and $\$ 0.049 \mathrm{GJ}^{-1}$ for the forwarder-bundle system. 

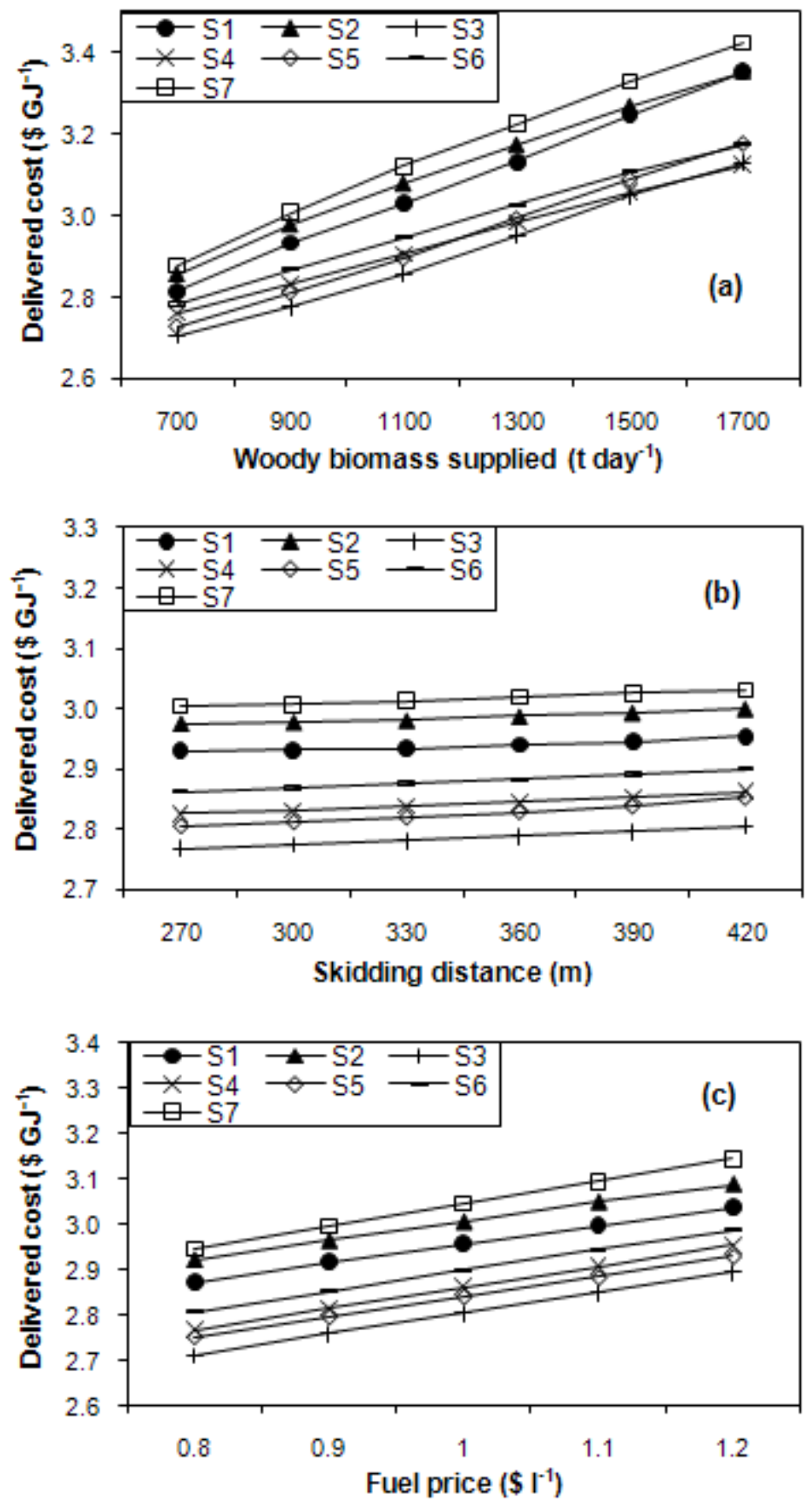

Figure 2.6. Sensitivity analyses of the delivered cost by woody biomass demand, skidding distance, and fuel price (dry weight). 


\subsection{Conclusions and Discussion}

The mixed integer programming model developed can be used to facilitate woody biomass handling cost analysis and to locate a potential woody biomass utilization plant under certain supply, demand, and other operational and market factors. For the base case scenario, the optimum biomass-based plant was located approximately at Addison (Forest District 3) in West Virginia, where abundant and inexpensive woody biomass could be provided. All the potential plant locations were initially assumed to be evenly distributed in six forest districts of West Virginia in the application. Other factors that could affect locating a woody biomass-based plant include the possibility of using existing facilities, accessibility to transportation networks and utilities, local community support, and target market for biofuels or bioproducts (CFDC and NEB 2006). All these factors should be considered in future research to obtain more precise, applicable plant locations and results.

The average delivered cost of woody biomass for the base case ranged from $\$ 2.77 \mathrm{GJ}^{-1}$ to $\$ 3.01 \mathrm{GJ}^{-1}$ using the different woody biomass handling systems. This estimation was within the range of $\$ 1.55-\$ 5.09 \mathrm{GJ}^{-1}$ (\$27 to $\$ 89$ dry metric ton $^{-1}$ ) estimated by Grushecky et al. (2007) for the same region. However, it was higher than the USDOE (US Department of Energy) target cost of $\$ 2.21 \mathrm{GJ}^{-1}\left(\$ 38.58\right.$ dry metric ton $\left.{ }^{-1}\right)$ in 2012 at which level the production cost of biofuels (ethanol) from woody biomass could be competitive with gasoline (Perlack et al. 2005). Several factors contribute to the higher delivered cost of woody biomass in the central Appalachian region, including the mountainous terrain, hardwood species, and fuel economy. Cable and grapple skidders are the most commonly used extraction machines partially due to the difficult terrain in the region. The fuel economy for hauling woody biomass in the region was estimated at $2.12 \mathrm{~km} \mathrm{l}^{-1}$ (5.0 miles gallon $\left.{ }^{-1}\right)$ after consulting with local loggers; however, it could be up to 
$3.83 \mathrm{~km} \mathrm{l}^{-1}\left(9\right.$ miles gallon $\left.{ }^{-1}\right)$ in other regions with gentle terrain (Jensen et al. 2002). More importantly, some of the cost estimate parameters were based on reasonable assumptions from literature and are subject to change. For instance, a large-scale woody biomass-based biofuels facility could increase demand competition for woody biomass and raise the price of raw materials. Fuel price can fluctuate with worldwide and regional supply and demand, seasonal demand, and other factors.

Sensitivity analyses demonstrated that woody biomass supplied level at the plant, purchase price of mill residue, and mill residue availability had greater impacts on the average delivered cost of woody biomass compared to the other factors. The skidding distance had the least impacts. The grapple skidder-loose residue system (S3) consistently presented the lowest delivered cost while the forwarder-bundle system (S7) was the most expensive system due to initial cost, production rate, payload size, and extraction distance of the system. The stabilization of feedstock supply is critical to success for a woody biomass-based biofuel plant. The 2005 Forest Inventory and Analysis (FIA) data for West Virginia showed a net annual growth to removal ratio of 1.08:1 for all species combined (USDA Forest Service 2008). It simply indicates that the net annual growth is greater than the annual removals of the growing stock. To secure the supply chain of woody biomass, it is essential to find niche supply markets for wood residues through long-term contracts, or collaborative relationships with landowners and major forest products companies. The average delivered cost of woody biomass varied significantly as demand at the plant changed. To determine a reasonable demand level, factors such as available funds, plant investment, land ownerships, and year-round feedstock supply stabilization also need to be addressed. 
The model developed in this study targets one optimal biofuel plant location considering biomass availability and size of the potential application area. Our future work in terms of model improvement will include multiple optimal plant locations and multiple feedstocks (woody biomass, agricultural residues, and municipal waste) based on the needs of application regions. A computer-aided tool should be developed to facilitate data entry, perform economic analysis, and generate spatial output. A life cycle analysis could also be included to address the environmental aspects and potential impacts associated with the process of woody biomass utilization for biofuels.

This study provides a basis for the analysis of the economic feasibility of using woody biomass as feedstock for bioenergy in the central Appalachian region and will help facilitate rural economic development in the region. Our findings would also be useful for researchers to assess woody biomass utilization for bioenergy in other regions. 


\section{References}

Appalachian Hardwood Center. 2006. TPO based logging residue totals by county within 100 miles of Pt. Pleasant, WV [online]. Available from http://ahc.caf.wvu.edu/ahc resources/Maps/Ptpleasant/Rev PtPles TPO Log Res.pdf [accessed 18 January 2009].

Bridgwater, A.V., Toft, A.J., and Brammer, J.G. 2002. A techno-economic comparison of power production by biomass fast pyrolysis with gasification and combustion. Renewable and Sustainable Energy Reviews 6: 181-248. doi:10.1016/S1364-0321(01)00010-7.

Brinker, R.W., Kinard, J., Rummer, B., and Lanford, B. 2002. Machine rates for selected forest harvesting machines. Alabama Agricultural Experiment Station, Auburn University, AL.

Bragonje, R., Grushecky, S., Spong, B., Slahor, J., and Osborn, L. 2006. West Virginia wood byproducts available and needed. West Virginia University, Morgantown, WV. pp. 1033.

Cusack, C. 2008. Harnessing the power of local wood energy [online]. Available from http://www.forestguild.org/publications/research/2008/Local_Wood_Energy.pdf [accessed 10 May 2009].

Clean Fuels Development Coalition (CFDC) and Nebraska Ethanol Board (NEB). 2006. A guide for evaluating the requirements of ethanol plants [online]. Available from http://www.ethanol.org/pdf/contentmgmt/guide for_evaluating the requirements_of_eth anol_plants.pdf [29 June 2009].

Caputo, A. C., Palumbo, M., Pelagagge, P. M., and Scacchia, F. 2005. Economics of biomass energy utilization in combustion and gasification plants: effects of logistic variables. Biomass and Bioenergy 28: 35-51. 
Dornburg, V., and Faaij, A.P.C. 2001. Efficiency and economy of wood-fired biomass energy systems in relation to scale regarding heat and power generation using combustion and gasification technologies. Biomass and Bioenergy 21: 91-108.

Griffith, D.M., and Widmann, R.H. 2003. Forest Statistics for West Virginia: 1989 and 2000. USDA For. Serv., Northeastern Research Station, Resource Bulletin NE-157.

Grushecky, S., McGill, D., and Anderson, R.B. 2006. Inventory of wood residues in Southern West Virginia. Northern J. of Appl. For. 23(1): 47-52.

Grushecky, S., Wang, J., and D. McGill, D. 2007. Influence of site characteristics and costs of extraction and trucking on logging residue utilization in southern West Virginia. For. Prod. J. 57(7/8): 63-67.

Galik, C.S., Abt, R., and Wu, Y. 2009. Forest biomass supply in the southeastern United Statesimplications for industrial roundwood and bioenergy production. Journal of Forestry March: 69-77.

Hartsough, B., Drews, E., McNeel, J., Durston, T., and Stokes, B. 1997. Comparison of mechanized systems for thinning ponderosa pine and mixed conifer stands. For. Prod. J. 47(11/12): 59-68.

Jensen, K., Menard, J., English, B., Park, W., and Wilson, B. 2002. The wood transportation and resource analysis system (WTRANS): an analysis tool to assist wood residue producers and users. For. Prod. J. 52(5): 27-33.

Johansson, J., Liss, J., Gullberg, T. and Björheden, R. 2006. Transport and handling of forest energy bundles-advantages and problems. Biomass and Bioenergy 30: 334-341. doi:10.1016/j.biombioe.2005.07.012. 
Kaylen, M., Van Dyne, D., Choi, Y., and Blase, M. 2000. Economic feasibility of producing ethanol from lignocellulosic feedstocks. Bioresource Technology 72: 19-32. doi:10.1016/S0960-8524(99)00091-7.

Kerstetter, J.D., and Lyons, J.K. 2001. Logging and Agricultural Residue Supply Curves for the Pacific Northwest. Washington State University Energy Program. Olympia, WA. DEFC01-99EE50616. 1p.

Kärhä, K., and Vartiamäki, T. 2006. Productivity and costs of slash bundling in Nordic conditions. Biomass and Bioenergy 30: 1043-1052. doi:10.1016/j.biombioe.2005.12.020.

Kumar, A., and Sokhansanj, S. 2007. Switchgrass delivery to a biorefinery using integrated biomass supply analysis and logistics (IBSAL) model. Bioresource Technology 98: 10331044. doi: 10.1016/j.biortech.2006.04.027.

Leinonen, A. 2004. Harvesting technology of forest residues for fuel in the USA and Finland. VTT Research Notes 2229. 46p.

Li, Y., Wang, J., Miller, G., and McNeel, J. 2006. Production economics of harvesting smalldiameter hardwood stands in central Appalachia. For. Prod. J. 56(3): 81-86.

Miyata, E.S. 1980. Determining fixed and operating costs of logging equipment. USDA For. Serv. Gen. Tech. Rept. NC-55.

Mapemba, L.D. 2005. Cost to deliver lignocellulosic biomass to a biorefinery. Ph.D. Dissertation. Oklahoma State University, Stillwater, OK. pp. 70-104.

Milauskas, S., and Wang, J. 2006. West Virginia logger characteristics. For. Prod. J. 56(2): 1924.

Perlack, R.D., Wright, L.L., Turhollow, A.F., Graham, R.L., Stokes, B.J., and Erbach, D.C. 2005. Biomass as feedstock for a bioenergy and bioproducts industry: the technical 
feasibility of a billion-ton annual supply. Oak Ridge National Laboratory, Oak Ridge, TN.

Pan, F., Han, H., Johnson, L.R., Elliot, W.J. 2008. Production and cost of harvesting, processing, and transporting small-diameter ( $\leq 5$ inches) trees for energy. For. Prod. J. 58(5): 47-52.

Richardson, J., Björheden, R., Hakkila, P., Lowe, A.T., and Smith, C.T. 2002. Bioenergy from sustainable forestry: guiding principles and practice. Springer. pp. 113-114.

Rummer, B., Len, D., and O’brien, O. 2004. Forest residues bundling project-new technology for residue removal. USDA For. Serv., Southern Research Station, Auburn, AL.

Summit Ridge Investments, LLC (SRI). 2007. Eastern hardwood forest region woody biomass energy opportunity. Granville, VT. pp. 34-37.

Scott, D.A., and Dean, T.J. 2006. Energy trade-offs between intensive biomass utilization, site productivity loss, and ameliorative treatments in loblolly pine plantations. Biomass Bioenergy 30(12): 1001-1010. doi:10.1016/j.biombioe.2005.12.014.

Spinelli, R., Nati, C., and Magagnotti, N. 2007. Recovering logging residue: experiences from the Italian Eastern Alps. Croatian J. of For. Eng. 28: 1-9.

Thek, G., and Obernberger, I. 2004. Wood pellet production costs under Austrian and in comparison to Swedish framework conditions. Biomass and Bioenergy 27: 671-693.

Tembo, G., Epplin, F.M., and Huhnke, R.L. 2003. Integrative investment appraisal of a lignocellulosic biomass-to-ethanol industry. J. of Agr. and Res. Eco. 3: 611-633.

U.S. Census Bureau. 2008. Three-year-average median household income by State: 2005 - 2007 [online]. Available from http://www.census.gov/hhes/www/income/statemedfaminc.html [accessed 16 August 2009]. 
U.S. Energy Information Administration. 2008. East coast No.2 diesel retail sales by all sellers [online]. Available from http://tonto.eia.doe.gov/dnav/pet/hist/ddr002w.htm [accessed 28 July 2008].

U.S. Energy Information Administration. 2010. Coal prices and outlook [online]. Available from http://tonto.eia.doe.gov/energyexplained/index.cfm?page=coal_prices [accessed 2 March 2010].

USDA Forest Service. 2008. Forest inventory and analysis national map maker program [online]. Available from http://www.ncrs2.fs.fed.us/4801/fiadb/fim21/wcfim21.asp [accessed 18 December 2008].

U.S. Department of State (USDS). West Virginia Weather [online]. 2009. Available from http://countrystudies.us/united-states/weather/west-virginia/ [accessed 28 June 2009].

West Virginia Division of Forestry (WVDOF). 2006 West Virginia Logging Sediment Control Act - 2006 Statistics. West Virginia Division of Forestry, Charleston, WV.

Wang, J. 2007. Hardwood log bucking and loading efficiency in West Virginia. For. Prod. J. 57(5): 1-7.

Weintraub, A., Jones, G., Magendzo, A., Meacham, M., and Kirby, M. 1994. A heuristic system to solve mixed integer forest planning models. Oper. Res. 42(6): 1010-1024. doi:10.1287/opre.42.6.1010.

Weintraub, A., Magendzo, A., Magendzo, A., Malchuk, D., Jones, G., and Meacham, M. 1995. Heuristic procedures for solving mixed-integer harvest scheduling-transportation planning models. Can. J. For. Res. 25: 1618-1626. doi:10.1139/x95-176.

Walsh, M.E., Perlack, R.L., Turhollow, A., Ugarte, D., Becker, D., Graham, R.L., Slinsky, S.E., and Ray, D.E. 1999. Biomass Feedstock Availability in the United States: 1999 State 
Level Analysis [online]. Available from http://bioenergy.ornl.gov/resourcedata/index.html [accessed 20 January 2008].

Wang, J., Long, C., and J. McNeel, J. 2004. Production and cost analysis of a feller-buncher and grapple skidder in central Appalachian hardwood forests. For. Prod. J. 54(12): 159-167.

Wang, J., Grushecky, S., and McNeel, J. 2006. Biomass Resources, Uses, and Opportunities in West Virginia. West Virginia University, Biomaterials Center, Morgantown, WV. 


\section{Appendix 2.A. List of symbols}

Table 2.A1. Data sets and descriptions.

\begin{tabular}{ll}
\hline Set & Description \\
\hline$I$ & Set of woody biomass supply counties, $i=\{$ All counties in West Virginia $\}$. \\
$J$ & Set of possible woody biomass-based plant locations, $j=\{$ Grafton, Moorefield, \\
& Addison, Shady Spring, Alum Creek, Grantsville $\}.$ \\
$H$ & Set of months, $m=\{1,2,3, \ldots, 12\}$. \\
& Woody biomass handling systems, $h=\{$ cable skidder-loose residue, cable \\
& skidder-chips, grapple skidder-loose residue, grapple skidder-chips, forwarder- \\
& loose residue, forwarder-chips, forwarder-bundle $\}.$ \\
$S$ & Mill residue types, $r=\{$ bark, chips, sawdust $\}$. \\
\hline
\end{tabular}


Table 2.A2. Parameters and descriptions.

\begin{tabular}{|c|c|}
\hline Parameter & Description \\
\hline$a_{s}$ & $\begin{array}{l}\text { Breakpoints over the quantity of annually delivered logging residue from } \\
\text { supply county } i \text {; }\end{array}$ \\
\hline$b c_{h}$ & $\begin{array}{l}\text { Bundling cost of logging residue associated with handling system } h(\$ \text { metric } \\
\left.\text { ton }^{-1}\right) \text {. }\end{array}$ \\
\hline$b i v_{i}$ & Volume of logging residue at supply county $i$ (metric tons). \\
\hline$b p_{i}$ & Proportion of logging residue available for extraction at supply county $i(\%)$. \\
\hline$b v s_{i}$ & $\begin{array}{l}\text { Volume of logging residue on sites with a slope of } 35 \% \text { or less at supply } \\
\text { county } i \text { (metric tons). }\end{array}$ \\
\hline$c s_{h}$ & In-woods chipping cost associated with handling system $h\left(\$\right.$ metric $\left.\operatorname{ton}^{-1}\right)$. \\
\hline$c p_{h}$ & Chipping cost at a plant associated with system $h\left(\$\right.$ metric $\left.\operatorname{ton}^{-1}\right)$. \\
\hline capacity & Woody biomass demand at plant (dry metric tons day ${ }^{-1}$ ). \\
\hline$d_{i j}$ & One way over-the-road distance between supply county $i$ to plant $j(\mathrm{~km})$. \\
\hline $\begin{array}{l}\text { distl } \\
\text { distm } \\
\text { dwh }\end{array}$ & $\begin{array}{l}\text { Averaged hauling distance of logging residue }(\mathrm{km}) \text {. } \\
\text { Averaged hauling distance of mill residue }(\mathrm{km}) \text {. } \\
\text { Driver's wages per hour including a fringe benefit rate at } 40 \%\left(\$ \mathrm{~h}^{-1}\right) \text {. }\end{array}$ \\
\hline$D_{b}$ & Logging residue spatial density (metric tons $\mathrm{km}^{-2}$ ). \\
\hline$e^{e x t} t_{m}$ & $\begin{array}{l}\text { Limitation of logging residue extracted in month } m \text { as a percentage of the } \\
\text { whole year (\%). }\end{array}$ \\
\hline$f_{\mathcal{C}_{s}}$ & Slope of the $\mathrm{s}^{\text {th }}$ line segment in the range $\left(a_{s-1}, a_{s}\right)$ \\
\hline$f p l$ & Fuel (diesel) price per liter $\left(\$ 1^{-1}\right)$. \\
\hline$h c_{h}$ & $\begin{array}{l}\text { Logging residue extraction cost associated with handling system } h \text { (\$ metric } \\
\operatorname{ton}^{-1} \text { ). }\end{array}$ \\
\hline iitr & Interest, insurance, and taxes rate of trucks (\%). \\
\hline $\mathrm{kpl}$ & The distance a fully loaded vehicle can travel on one liter of fuel $\left(\mathrm{km} \mathrm{l}^{-1}\right)$. \\
\hline$k p h$ & Average travel speed of a fully loaded vehicle $\left(\mathrm{km} \mathrm{h}^{-1}\right)$. \\
\hline$l c_{h}$ & Loading cost of woody biomass associated with system $h\left(\$\right.$ metric $\left.\operatorname{ton}^{-1}\right)$. \\
\hline $\operatorname{load}_{h}$ & Vehicle payload associated with handling system $h$ (metric tons). \\
\hline $\operatorname{lm} c$ & Average moisture content of logging residue $(\%)$ \\
\hline$m c_{r}$ & Purchase price for mill residue type $r\left(\$\right.$ metric $\operatorname{ton}^{-1}$ ). \\
\hline$m t$ & Mill residue transportation cost rate ( $\$$ metric ton $\left.^{-1} \mathrm{~km}^{-1}\right)$. \\
\hline$m i v_{i r}$ & Volume of mill residue $r$ at supply county $i$ (metric tons). \\
\hline$m m c_{r}$ & Moisture content of mill residue type $r(\%)$. \\
\hline$m p_{i r}$ & Proportion of mill residue $r$ available at supply county $i(\%)$. \\
\hline $\begin{array}{l}m r \\
\text { mnbin }\end{array}$ & $\begin{array}{l}\text { Maintenance and repair rate, expressed as a percentage of depreciation (\%). } \\
\text { Minimum inventory at a plant (dry metric tons). }\end{array}$ \\
\hline
\end{tabular}


Table 2.A2. Parameters and descriptions (continued).

\begin{tabular}{|c|c|}
\hline Parameter & Description \\
\hline$n$ & Vehicle economic life (yr). \\
\hline$n l_{i}$ & Number of loggers in supply county $i$. \\
\hline$n m_{h}$ & Average number of extraction machines that a logging crew owns. \\
\hline$p_{h}$ & $\begin{array}{l}\text { Productivity of extraction machine associated with handling system } h \text { (metric } \\
\text { tons } \mathrm{h}^{-1} \text { ). }\end{array}$ \\
\hline$r s_{i}$ & Half of the longest straight-line distance of supply county $i(\mathrm{~km})$. \\
\hline$s c$ & Logging residue storage cost in the field $\left(\$\right.$ metric $\left.\operatorname{ton}^{-1}\right)$. \\
\hline$s p$ & Stumpage price (purchase cost) of logging residue $\left(\$\right.$ metric $\left.\operatorname{ton}^{-1}\right)$. \\
\hline smh & Scheduled trucking hours per year $\left(\mathrm{h} \mathrm{yr}^{-1}\right)$. \\
\hline$\tau_{i j h}$ & $\begin{array}{l}\text { Round trip transportation cost from supply county } i \text { to plant } j \text { for system } h(\$ \\
\text { metric } \text { ton }^{-1} \text { ). }\end{array}$ \\
\hline$t_{h}$ & Off-highway transportation cost rate for system $h\left(\$\right.$ metric ton $\left.{ }^{-1} \mathrm{~km}^{-1}\right)$. \\
\hline$t p$ & Transportation vehicle purchase price (\$). \\
\hline ts & $\begin{array}{l}\text { Vehicle salvage value (\$), calculated as a percentage of vehicle purchase } \\
\text { price. }\end{array}$ \\
\hline$t_{i j}$ & The total cost per vehicle load from supply location $i$ to plant location $j(\$)$. \\
\hline$u t$ & Average vehicle annual utilization rate (\%). \\
\hline$\lambda$ & Monthly productive time per machine (h). \\
\hline$\rho$ & Scheduled working days of the plant per month (days). \\
\hline$\delta$ & Loss rate of woody biomass due to transportation $(\%), \delta=2 \%$. \\
\hline$\theta_{i}$ & Usable proportion of stored logging residue at supply location $i(\%)$. \\
\hline$\phi$ & Usable proportion of stored woody biomass at a plant (\%). \\
\hline
\end{tabular}


Table 2.A3. Variables and descriptions.

\begin{tabular}{|c|c|}
\hline Variable & Description \\
\hline$\alpha_{\text {ih }}$ & $\begin{array}{l}\text { A binary variable related to woody biomass handling system } h \text { at supply } \\
\text { county } i, \alpha_{i h}=\{0,1\} \text {. }\end{array}$ \\
\hline$\beta_{j}$ & A binary variable related to plant $j, \beta_{j}=\{0,1\}$. \\
\hline lct & Under-estimated transportation cost (\$). \\
\hline$s m_{i}$ & $\begin{array}{l}\text { Average turnover for delivering biomass within supply county } i \text { (metric ton- } \\
\mathrm{km} \text { ). }\end{array}$ \\
\hline$x h_{i h m}$ & $\begin{array}{l}\text { Quantity of logging residue extracted in month } m \text { at supply county } i \text { using } \\
\text { system } h \text { (metric tons). }\end{array}$ \\
\hline$x t_{i j h m}$ & $\begin{array}{l}\text { Quantity of logging residue delivered from supply county } i \text { to plant } j \text { in } \\
\text { month } m \text { associated with system } h \text { (metric tons). }\end{array}$ \\
\hline$x p s_{i h m}$ & $\begin{array}{l}\text { Quantity of logging residue entered into storage at supply county } i \text { in month } \\
m \text { associated with system } h \text { (metric tons). }\end{array}$ \\
\hline$x m_{i j r m}$ & $\begin{array}{l}\text { Quantity of mill residue } r \text { delivered from supply county } i \text { to plant } j \text { in } \\
\text { month } m \text { (metric tons). }\end{array}$ \\
\hline$x s_{i h m}$ & $\begin{array}{l}\text { Quantity of logging residue stored at supply county } i \text { in month } m \text { associated } \\
\text { with system } h \text { (metric tons). }\end{array}$ \\
\hline$x s n_{i h m}$ & $\begin{array}{l}\text { Quantity of logging residue removed from storage at supply county } i \text { in } \\
\text { month } m \text { associated with system } h \text { (metric tons). }\end{array}$ \\
\hline$x S S_{j m}$ & Quantity of woody biomass stored at plant $j$ in month $m$ (dry metric tons). \\
\hline$x p p_{j m}$ & $\begin{array}{l}\text { Quantity of woody biomass processed at plant } j \text { in month } m \text { (dry metric } \\
\text { tons). }\end{array}$ \\
\hline$x t l_{i j h s}$ & $\begin{array}{l}\text { Increment of logging residue annually shipped out of supply county } i \text { to } \\
\left.\text { plant } j \text { associated with system } h \text { in the range ( } a_{s-1}, a_{s}\right) \text { (metric tons). }\end{array}$ \\
\hline$z$ & Total annual delivered cost of woody biomass (\$). \\
\hline
\end{tabular}


CHAPTER 3: ECONOMIC FEASIBILITY OF A WOODY BIOMASS-BASED

ETHANOL PLANT IN CENTRAL APPALACHIA, USA*

\footnotetext{
* Submitted to Journal of Agricultural and Resource Economics.
} 


\begin{abstract}
A mixed integer programming model was developed to assist in siting a woody biomassbased ethanol facility based on the economic feasibility. The model is designed to maximize the net present value (NPV) of a facility over its economic life. Model inputs include biomass availability, biomass handling system type, plant investment and capacity, transportation logistics, feedstock and product pricing, project financing, and taxes. Four alternative woody biomass handling systems which include all the processes from forest to the plant are considered. The model was applied in the central Appalachian hardwood region. Eleven feasible plant locations were identified based on the requirements of site selection. Results showed that the optimal plant location was in Buckhannon, West Virginia. The NPV of the plant with a demand of 1,814 metric tons (2,000 dry tons) per day of woody biomass and plant life of 20 years varied from $\$ 17.28$ million to $\$ 35.54$ million among the systems. The average production cost of ethanol was approximately $\$ 1.92-\$ 1.98$ per gallon. It was found that the production cost was most impacted by biomass availability, mill residue purchase price, plant investment and capacity, ethanol yield, and financing. Findings suggest that a woody biomass-based ethanol facility in central Appalachia could be economically feasible under certain operational scenarios.
\end{abstract}

\title{
3.1 Introduction
}

Recently, the interest in using biomass as feedstock for biofuel production in the United States has been increasing due to the concerns about volatile oil prices, climate change, and the impact of diverting crops from food to fuel. Woody biomass is a potentially important feedstock for biofuels (Perlack et al. 2005). Wood-based biomass includes residues produced during timber harvesting, fuelwood extracted from forestlands, and residues generated at primary and secondary wood processing facilities (Wang et al. 2006). A variety of liquid fuels can be 
produced from woody biomass, however, ethanol is one of the most promising (Tyner and Taheripour 2007). Most ethanol currently produced in the U.S. is from fermentation of corn, which has been blamed for driving up food prices (Taheripour and Tyner 2008). Cellulose ethanol, a type of biofuel produced from lignocellulose, has all the advantages of corn-based ethanol such as renewable and clean but can be made from a variety of non-food raw materials such as corn stover, switchgrass, and woody biomass. Laboratory testing has demonstrated the technical feasibility of converting woody biomass into ethanol (Zerbe 1991), however, the economic viability of a commercial scale woody biomass-based ethanol plant has not been fully addressed.

An economic feasibility study of a biomass-based facility considers investment, operating costs, time value of money, risk and uncertainty, quality of available data, and a sensitivity analysis to assess the robustness of the results. Some studies for estimating the economic feasibility of cellulosic ethanol have been conducted in the U.S. Kaylen et al. (2000) built a mathematical model to analyze the economic feasibility of producing ethanol from lignocellulosic feedstocks (crop residues and woody biomass). Four cost modules including capital cost, operating cost, feedstock cost, and transportation cost were considered in their model. The optimal size of an ethanol plant was determined by the trade-off between increasing transportation costs for feedstock versus decreasing average plant costs as the plant size increases. Kaylen et al. (2000) determined that the optimal plant used 3,964 dry metric tons of feedstock per day, primarily crop residues with some woody biomass. Tembo et al. (2003) developed a multi-region, multi-period, mixed integer mathematical programming model encompassing alternative feedstocks (corn stover, native perennial grasses, and switchgrass), feedstock production, delivery, and processing methods. The most economically efficient source 
of lignocellulosic biomass, timing of harvest and storage, inventory management, and biorefinery size and location for a gasification-fermentation process can be determined in the model. Five large (100 million gallons per year) and one medium (50 million gallons per year) biorefineries were optimally located with an expected Net Present Value (NPV) of $\$ 1,143$ million over a 15year plant life. Mapemba (2005) made some modifications to Tembo's model by adding harvesting systems and suitable harvest days. However, none of these studies considered the handling activities involved in using woody biomass. Kaylen et al. (2000) used purchase price as feedstock cost and estimated the transportation cost using a grid system, rather than actual distance. Tembo et al. (2003) and Mapemba (2005) focused on agricultural residues, which required different harvest systems from woody biomass. Other studies performed economic analysis of lignocellulosic biomass to ethanol plant using Geographic Information System (GIS). Graham et al. (2000) used GIS to estimate the cost and environmental implications of supplying specific amounts of energy crop feedstock to a biorefinery. Noon et al. (2002) identified candidate switchgrass-to-ethanol conversion plant locations using GIS-based analysis of marginal price (delivered cost) variation in Alabama. Results showed that Southern Alabama is the most promising area for switchgrass-to-ethanol plants. Even though the GIS models can provide direct-viewing, the results tend to be static and other site selection criteria such as availability of utilities and access to pre-existing infrastructure were not considered.

Located in central Appalachia, West Virginia is the third most forested state in the U.S., and the harvesting process annually yields approximately 2.19 million dry metric tons of wood residue (Wang et al. 2006). A small portion of logging residue is used for firewood or other purposes in West Virginia. However, there are no statistical data to indicate the amount of logging residue being used annually for these or other purposes (Wang et al. 2006). The 
demand/supply ratio of mill residue in West Virginia averaged 68\% in 2005 (Wang et al. 2006).

There is a growing interest in more efficient utilization of wood residues and conversion of these underutilized materials to biofuels. Currently, there is no large-scale woody biomass-based biofuel facility operating in the state. Industries that could use woody biomass as a feedstock, such as biorefining, biochemicals and biopolymers, have limited start-up potential due to a lack of solid economic and business related information. Therefore, the objectives of this paper are to (1) develop an economic model to assess economic feasibility of an ethanol plant which incorporates woody biomass handling systems, biomass availability/accessibility, plant investment and capacity, transportation logistics, feedstock and product pricing, project financing, and taxes; and (2) conduct sensitivity analyses to assess the impacts of the above factors on the economic feasibility of a woody biomass-based ethanol plant in the central Appalachian region.

\subsection{Methods and Materials}

\subsubsection{Model development}

\section{Objective function}

Several types of investment appraisals can be used to assess whether an investment project is worthwhile or not, such as payback period, accounting rate of return (ARR), internal rate of return (IRR), profitability index, and net present value (NPV) (McMenamin 1999). The NPV is by far the most common project evaluation approach used by firms (Volker et al. 2009).

A mixed integer programming model would be more appropriate than a linear programming model for optimizing site location because a binary variable associated with site location could be an integer ( 0 or 1$)$. Therefore, a mixed integer programming model is 
developed in the paper to maximize the NPV of a woody biomass-based ethanol facility. The model is solved using General Algebraic Modeling System (GAMS)/CPLEX, a high-level modeling system for mathematical programming and optimization. All the notations for variables and symbols used in the model can be found in Appendix 3.A. The NPV is a function of annual revenue $\left(R_{n}\right)$, annual feedstock cost $\left(F_{n}\right)$, operating and maintenance cost $\left(O M_{n}\right)$, income taxes $\left(T_{n}\right)$, and plant investment $(\Omega)$. It is assumed that $R_{n}, F_{n}$, and $O M_{n}$ are constant across years $\left(R_{n}=R, F_{n}=F, O M_{n}=O M\right.$ for all $\left.n\right)$. The depreciation $\operatorname{cost}\left(C_{n}\right)$ and income taxes are the only things that change across years. Therefore, the objective of the model is expressed as:

$\operatorname{Max} \quad N P V=\sum_{n=1}^{N}\left(R_{n}-F_{n}-O M_{n}-T_{n}\right) \cdot P V I_{n}-\Omega=\sum_{n=1}^{N}\left(R-F-O M-T_{n}\right) \cdot P V I_{n}-\Omega$

The annual revenue $R$ is the sum of the sale of each product $g$ (ethanol or electricity) at plant location $j$ throughout the year (Eq. (3.2)). Ethanol is the main product of the co-current dilute acid prehydrolysis and enzymatic hydrolysis (Wooley et al. 1999). The process produces excess steam that is used to generate electricity for use in the plant and for sale to the grid. $R=\sum_{j=1}^{J} \sum_{g=1}^{G} \sum_{m=1}^{12} P_{g} \cdot q_{j g m}$

Logging and mill residues are assumed to be the primary feedstock for ethanol production in central Appalachia. Based on the two commonly used extraction machines (cable and grapple skidders) and biomass forms (loose residue and chips) delivered in the region, four woody biomass handling systems were considered in the model: cable skidder-loose residue (S1), cable skidder-chips (S2), grapple skidder-loose residue (S3), and grapple skidder-chips (S4). 
The annual feedstock cost $(F)$ includes the cost components associated with woody biomass purchase cost, extraction, storage, loading and hauling, chipping/grinding, and transportation, which is computed using Eq. (3.3) (Wu et al. 2008). The woody biomass supply locations were represented by counties in the study region and a town located near the geographic center of each county was used to represent the location for that county. $L C T$ is the under-estimated transportation cost. The reason for calculating $L C T$ is that $\sum T C_{i j h} \cdot x t_{i j h m}$ in Eq. (3.3) may underestimate the actual transportation cost if the supply and plant locations are in the same county or adjacent counties $\left(D_{i j} \leq R S_{i}\right)$.A nonlinear transportation cost model developed by Dornburg and Faaij (2001) can be used to determine the under-estimated cost LCT . To make the MIP model solvable, the separable programming (Taha 2006) was used to convert the nonlinear model into a piecewise linear function.

$$
\left\{\begin{aligned}
F= & \sum_{i=1}^{I} \sum_{h=1}^{H} \sum_{m=1}^{12}\left[\left(H C_{h}+S P\right) \cdot x h_{i h m}+S C \cdot x p s_{i h m}\right]+\sum_{i=1}^{I} \sum_{j=1}^{J} \sum_{h=1}^{H} \sum_{m=1}^{12}\left(T C_{i j h}+L C_{h}+C S_{h}+C P_{h}\right) \cdot x t_{i j h m} \\
& +\sum_{i=1}^{I} \sum_{j=1}^{J} \sum_{m=1}^{12}\left(M C+M T \cdot D_{i j}\right) \cdot x m_{i j m}+L C T \\
L C T= & \sum_{i=1}^{I} \sum_{j=1}^{J} \sum_{h=1}^{H} \sum_{s=1}^{S} T_{h} \cdot F C_{s} \cdot x t l_{i j h s}, \text { whereD }_{i j} \leq R S_{i}, 0 \leq x t l_{i j h s} \leq a_{s}-a_{s-1} . \\
\sum_{s=1}^{S} x t l_{i j h s} & =\sum_{m=1}^{12} x t_{i j h m}, \forall i, j, h .
\end{aligned}\right.
$$

Total investment cost $\Omega$ in Eq. (3.4) is the sum of each individual investment cost $T P C_{j}$ at each possible plant location. $\beta_{j}$ is a binary variable related to investment decision, $\beta_{j}=\{0,1\}$. If $\beta_{j}=1$, a facility will be built at location $j, 0$ otherwise. The other associated costs such as warehouse, site development, and field expense are included in $T P C_{j}$. Construction cost of the plant can easily differ due to site characteristics and other factors. Here it is assumed to be 
the same for all the possible plant locations. The order of magnitude estimation method was used to estimate the investment cost of a woody biomass-based ethanol plant in Eq. (3.5). This method uses the seven-tenth power law exponent to scale investment cost from known investment cost data (Ulrich 1984). The Marshall \& Swift (M\&S) all industry equipment cost index was used to adjust the cost from a historical year to the initial project year. It is also assumed that there is one ethanol plant to be built in the study region in Eq. (3.6).

$$
\begin{aligned}
& \Omega=\sum_{j=1}^{J} \beta_{j} T P C_{j} \\
& T P C_{j}=T P C_{0}\left(C A P A C I T Y / C A P A C I T Y_{0}\right)^{0.7}\left(M S / M S_{0}\right) \\
& \sum_{j=1}^{J} \beta_{j}=1
\end{aligned}
$$

Operating and maintenance cost $(O M)$ is estimated in terms of variable and fixed operating costs. Variable operating cost includes waste handling charges, water consumption, and chemical inputs and it is a linear function of the plant capacity (Kaylen et al. 2000). Fixed operating cost includes labor, overhead, maintenance, and insurance \& property taxes. The fixed operating cost exhibits economies of scale, which is estimated using the order of magnitude method.

The income taxes $T_{n}$ at the $n^{\text {th }}$ year are calculated by Eq. (3.7). Since the taxable income $\left(R-F-O M-C_{n}\right)$ is usually negative at the initial stages of the project (e.g., $1^{\text {st }}$ year), zero tax is applied instead of negative tax. $C_{n}$ is the capital depreciation at the $n^{\text {th }}$ project year.

$T_{n}=\left(R-F-O M-C_{n}\right) \cdot t, \forall n$.

The IRS Modified Accelerated Cost Recovery System (MARCS) required by the United States income tax code was used to determine the capital depreciation cost (Short et al. 1995). 
The General Depreciation System (GDS) within the MARCS allows both $200 \%$ and $150 \%$ declining balance (DB) of depreciation. Short et al. (1995) also reported that steam production plants should use a 20 -year recovery period with $150 \%$ DB depreciation and other property unspecified should use a 7-year recovery period with 200\% DB depreciation. In this study, the plant is segmented into a general plant and a steam plant using the methods by Wooley et al. (1999). The depreciation cost of the plant is computed using Eqs. (3.8) - (3.13). The sum of the unrecovered capital cost of the general and steam plant on the first year is equal to the plant investment cost in Eq. (3.8). The recovery period of each type of facility is: $N R_{\text {general }_{-} \text {plant }}=7$, $N R_{\text {steam }_{-} \text {plant }}=20$. Eqs. (3.9) - (3.12) are used to compute the depreciation cost of the general (or steam) plant each year. The total depreciation at the $n^{\text {th }}$ year is the sum of the depreciation cost of the general and the steam plant (Eq. (3.13)).

$$
T P C_{j}=\sum_{k=1}^{K} C R_{k 1}
$$

$C F D_{k n}=\left\{\begin{array}{l}\frac{2 C R_{k n}}{N R_{k}}, n \leq N R_{k}, \text { where } k=1 . \\ \frac{1.5 C R_{k n}}{N R_{k}}, n \leq N R_{k}, \text { where } k=2 . \\ 0 \quad, \forall k, n>N R_{k} .\end{array}\right.$

$$
C F S_{k n}= \begin{cases}\frac{C R_{k n}}{N R_{k}-n+1}, & \forall k, n \leq N R_{k} . \\ 0 \quad, \forall k, n>N R_{k} .\end{cases}
$$

$C F_{k n}=\max \left(C F D_{k n}, C F S_{k n}\right), \quad \forall k, n$.

$$
C R_{k n+1}=C R_{k n}-C F_{k n}, \quad \forall k, n=1,2, \cdots, N-1 .
$$




$$
C_{n}=\sum_{k=1}^{K} C F_{k n}, \quad n=1,2, \cdots, N
$$

The present value index $P V I_{n}$ at the $n^{\text {th }}$ year depends on the selection of the discount rate which can greatly affect the economics and the decision making, particularly in capital-intensive projects like ethanol facilities. The discount rate can be thought of as an opportunity cost. Investors will require a rate of return at least as great as the percentage return they can earn in the most nearly comparable investment opportunity. Since there remain uncertainties in determining the opportunity cost, the most widely accepted approach, weighted average cost of capital (WACC), was used as the discount rate for the project, which is expressed in Eq. (3.14). The $P V I_{n}$ is given by Eq. (3.15).

$$
\begin{aligned}
& W A C C=w_{e} r_{e}+\left(1-w_{e}\right) \cdot r_{d} \cdot(1-t) \\
& P V I_{n}=\frac{1}{(1+W A C C)^{n}}, \forall n .
\end{aligned}
$$

\section{Constraints}

Several constraints are considered in relation to the logistic process of woody biomass handling from the forest to the plant gate. It is assumed that there is one woody biomass handling system used at each supply location and the model evaluates each woody biomass handling system separately (Eq. (3.16)). The index of handling system $h$ ranges from 1 to 4 . As stated by Eq. (3.16), the model will evaluate the cable skidder-loose residue system (S1). The parameter $A L F A_{\text {ih }}$ for other handling systems (S2-S4) will be equal to zero.

$$
\left\{\begin{array}{l}
\sum_{h=1}^{H} A L F A_{i h}=1, \forall i, h=1,2, \cdots, 4 . \\
A L F A_{i h}=1, \forall i, \text { where } h=1 .
\end{array}\right.
$$


The quantity of logging residue annually extracted using system $h$ at supply location $i$ should be less than the available logging residue at that location (Eq.(3.17)). In terms of biomass accessibility, a terrain constraint is considered to further limit logging residue availability. All of the extraction machines are assumed to be able to operate on forest lands with a slope of $35 \%$ or less. The amount of logging residue extracted is also subject to the availability of logging residue for a specific time period (Eq. (3.18)) and extraction capacity of local loggers (Eq. (3.19)). Wet or other extreme weather can limit loggers' ability to operate their harvesting equipment due to site accessibility, safety and environmental concerns (Cusack 2008). There are certain times of the year when harvesting is limited due to wet or other extreme weather. An average rate of logging residue availability was evenly assigned for each month within a year. For instance, the logging residue extracted cannot be more than $1 / 12$ of the total available amount if extracted in January. Then, this rate was adjusted based on historical production data and monthly precipitation in the study region. Local loggers' capability of extracting logging residue is defined by $\lambda P D_{h} N L_{i} N M_{h}$. Where, $\lambda$ is monthly productive time per machine, $P D_{h}$ is productivity of extraction machine associated with system $h, N L_{i}$ is the number of loggers at supply location $i$, and $N M_{h}$ is the number of extraction machines that a logging crew uses. The availability of mill residue is described by Eq. (3.20) (Wu et al. 2008).

$$
\begin{aligned}
& \left\{\begin{array}{l}
\sum_{m=1}^{12} x h_{i h m}-A L F A_{i h} \cdot B P_{i} \cdot B I V_{i} \leq 0, \forall i, h . \\
\sum_{m=1}^{12} x h_{i h m}-A L F A_{i h} \cdot B P_{i} \cdot B V S_{i} \leq 0, \forall i, h .
\end{array}\right. \\
& \sum_{h=1}^{H} x h_{i h m}-E X T_{m} \cdot B P_{i} \cdot B V S_{i} \leq 0, \forall i, m . \\
& x h_{i h m}-\lambda \cdot P D_{h} \cdot N L_{i} \cdot N M_{h} \leq 0, \forall i, h, m .
\end{aligned}
$$


$\sum_{j=1}^{J} \sum_{m=1}^{12} x m_{i j m}-M P_{i} \cdot M I V_{i} \leq 0, \forall i$

The total logging residue shipped to plant locations plus the amount stored at landings should not exceed the total logging residue extracted at current month and the usable portion of logging residue stored (Eq. (3.21)) (Tembo et al. 2003). The storage balance of logging residue for one year is expressed as Eq. (3.22). The interrelationship among logging residue extracted, logging residue entered into storage and removed from storage, and logging residue transported to demand locations is described in Eq. (3.23).

$$
\begin{aligned}
& x h_{i h m}+\theta_{i} x s_{i h m-1}-\sum_{j=1}^{J} x t_{i j k m}-x s_{i h m} \geq 0, \forall i, h, m . \\
& \sum_{m=1}^{12} \sum_{h=1}^{H} x h_{i h m}-\left(1-\theta_{i}\right) \sum_{m=1}^{12} \sum_{h=1}^{H} x s_{i h m}-\sum_{j=1}^{J} \sum_{h=1}^{H} \sum_{m=1}^{12} x t_{i j h m}=0, \forall i . \\
& \sum_{h=1}^{H} x h_{i h m}-\sum_{h=1}^{H} x p s_{i h m}+\sum_{h=1}^{H} x S n_{i h m}-\sum_{h=1}^{H} \sum_{j=1}^{J} x t_{i j h m}=0, \forall i, m .
\end{aligned}
$$

The total woody biomass delivered to an ethanol plant $j$ plus the usable biomass stored in the previous months at the plant $\left(\phi x s s_{j m-1}\right)$ should be equal to the amount of woody biomass stored $\left(x s s_{j m}\right)$ and being processed at current month $\left(x p p_{j m}\right)$ (Eq. (3.24)).

$$
\sum_{i=1}^{I} \sum_{h=1}^{H}(1-\delta) x t_{i j h m}+\sum_{i=1}^{I} x m_{i j m}+\phi x s s_{j m-1}-x s s_{j m}-x p p_{j m}=0, \forall j, m
$$

The amount of woody biomass processed $\left(x p p_{j m}\right)$ in month $m$ at plant location $j$ is equal to the feedstock demand (30 CAPACITY) at that location (Eq. (3.25)). $\sigma$ is the moisture content of woody biomass. The plant is assumed to have 30 scheduled working days per month.

$$
(1-\sigma) \cdot x p p_{j m}-30 C A P A C I T Y \cdot \beta_{j}=0, \forall j, m
$$


The amount of product $g$ produced at plant location $j$ in month $m\left(q_{j g m}\right)$ is less than the amount of dry woody biomass processed multiplying by the corresponding yield $\left(\eta_{g}\right)$ from one dry metric ton of woody biomass.

$q_{j g m}-(1-\sigma) \cdot \eta_{g} \cdot x p p_{j m} \leq 0, \forall j, g, m$.

The inventory of woody biomass at a plant $\left(x s s_{j m}\right)$ should be greater than the minimum inventory defined to ensure continuous production.

$x S s_{j m}-M N B I N \cdot \beta_{j} \geq 0, \forall j, m$.

Finally, the following decision variables should be nonnegative:

$x h, x t, x t l, x m, x s, x p s, x s n, x s s, x p p, q \geq 0$

Given base values for all the parameters, the above model which integrates multiple equations can be solved using GAMS/CPLEX solver and the optimal plant location, NPV, and quantity of woody biomass delivered by handling system can be determined. Note that if the income taxes in the first few years were negative, the NPV would be adjusted accordingly. The internal rate of return (IRR) of the optimal plant will then be derived from the model solution.

\subsubsection{Model assumptions}

Supply and plant locations

The model was applied in the central Appalachian hardwood region, U.S. Ninety-nine

counties in West Virginia and part of Virginia, Kentucky, Ohio, and Pennsylvania were selected as potential woody biomass supply sources (Figure 3.1). A town near the geographic center of each county was used to represent the average location for the county. Many factors should be considered when choosing a woody biomass-based ethanol plant location, including feedstock availability, utilities (such as electricity, gas, and water) availability and cost, transportation 
(such as highways or railroads), site size, product market, and community support (Blagojevich et al. 2006, Clean Fuels Development Coalition and Nebraska Ethanol Board, 2006). Proximity and availability of woody biomass as well as competition from other uses are the primary concerns about plant location, because a guaranteed supply of woody biomass at a competitive price within a reasonable radius of an ethanol plant is critical for the profitability and viability of the plant. An intermediate size (50 million gallons per year) ethanol plant may require 4-6 ha land depending on plant technology and configuration (Clean Fuels Development Coalition and Nebraska Ethanol Board 2006). In this study, feasible sites for woody biomass-based ethanol plants were selected from available industrial parks due to availability of utilities and easy access to pre-existing infrastructure. A total of 15 out of 110 industrial parks in West Virginia were selected based on city limits, attainability, non-attainment area (which is designated by the U.S. Environmental Protection Agency), utility (electricity and gas) availability, access to water and sewer, continuous land area greater than 4 ha, and within a distance of $16 \mathrm{~km}$ from interstate highways. The selected industrial parks were represented by towns where they are located. If two industrial parks were located in the same town, they were treated as one feasible plant location. As a result, eleven unique locations were identified as feasible plant locations (Figure 3.1). They were: Beaver (Raleigh), Belington (Barbour), Bluefield (Mercer), Buckhannon (Upshur), Holden (Logan), Kenna (Jackson), Millwood (Jackson), Morgantown (Monongalia), Oak Hill (Fayette), Point Pleasant (Mason), and Williamson (Mingo). The names in the brackets are the counties where the cities are located. Distances over-the-road between supply and plant locations were computed based on an online distance calculator (MyRatePlan.com 2008). 


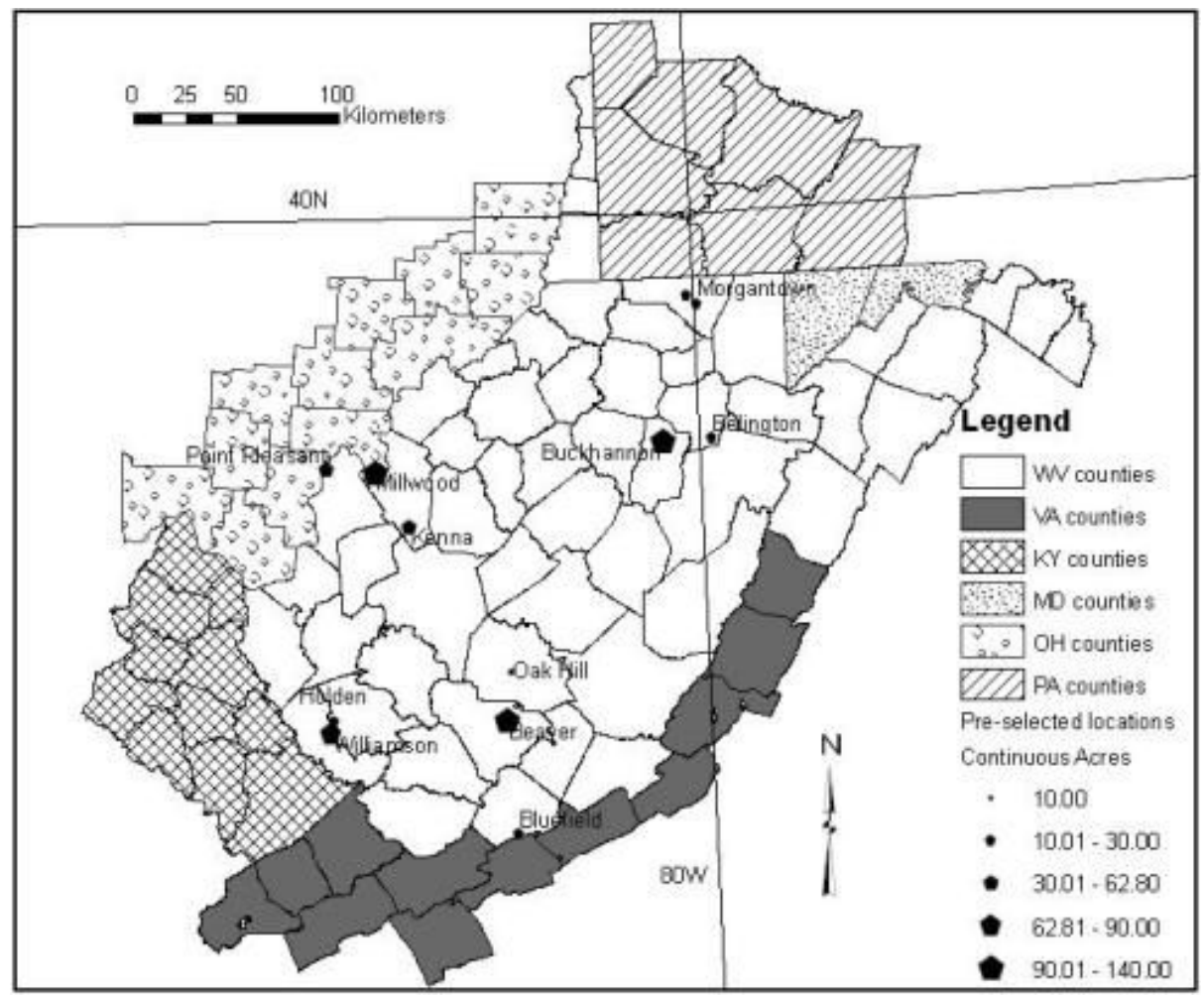

Figure 3.1. Pre-selected woody biomass-based potential ethanol plant locations and biomass supply counties.

\section{Woody biomass availability and characteristics}

The volume of logging residue by county was computed based on annual harvested area obtained from West Virginia Forestry Statistics (WVDOF 2006) and logging residue spatial density from a previous survey (Grushecky et al. 2006). Data from an annual report of wood byproducts by West Virginia University’s Appalachian Hardwood Center (Bragonje et al. 2006) were used to estimate the annual production of mill residue in West Virginia. Wood residues in the neighboring states of West Virginia were based on the USDA Forestry Inventory and Analysis (FIA) - Timber Product Output (TPO) data (USDA-FS 2008). The recovery rate of logging residue in West Virginia was assumed to be 65 percent on harvested sites with a slope of 35 percent or less in consideration of operational accessibility and economic feasibility in the region. The percentage of forest lands in West Virginia that meet this requirement ranges from 
$24 \%$ to $92 \%$ by county. Forty percent of mill residue was assumed to be available for ethanol production (Wang et al. 2006). The average moisture content of woody biomass was assumed to be $43 \%$ (wet basis) (Wang et al. 2006). The assumptions related to feedstock logistics including hourly machine cost, machine productivity, and cost per ton of production during woody biomass handling process are presented in Table 3.1. Hourly machine cost was computed using machine rate method (Miyata 1980). The productivity of handling machines (skidders, loader, and chippers) were based on the existing models developed for the central Appalachian hardwood region and other literature (Wang et al. 2004, Kärhä and Vartiamäki 2006, Li et al. 2006). Transportation cost was assumed to be $\$ 0.18 \mathrm{t}^{-1} \mathrm{~km}^{-1}$ for loose residue and $\$ 0.12 \mathrm{t}^{-1} \mathrm{~km}^{-1}$ for wood chips, respectively (Kerstetter and Lyons 2001).

Table 3.1. Cost assumptions for woody biomass handling machines in central Appalachia.

$$
\text { Hourly cost }\left(\$ \mathrm{~h}^{-1}\right) \quad \text { Productivity }\left(\mathrm{t} \mathrm{h}^{-1}\right) \quad \text { Unit cost }\left(\$ \mathrm{t}^{-1}\right)^{\mathrm{a}}
$$

\begin{tabular}{lccc}
\hline Cable skidder & 81.34 & 6.34 & 12.83 \\
Grapple skidder & 102.72 & 11.46 & 8.96 \\
Loader & 85.96 & 16.04 & 5.36 \\
Chipper & 185.62 & 30 & 6.19 \\
Grinder & 212.27 & 91 & 2.33 \\
\hline
\end{tabular}

\footnotetext{
${ }^{a}$ green ton basis.
}

\section{Plant assumptions}

The co-current dilute acid prehydrolysis and enzymatic hydrolysis was considered as the conversion method from woody biomass to ethanol as described by Wooley et al. (1999). Since yellow-poplar and oaks are the most common hardwood species in central Appalachia (USDAFS 2008), it is appropriate to assume the yield of woody biomass-derived ethanol to be $2901 \mathrm{t}^{-1}$ (70 gallons dry short ton ${ }^{-1}$ ) (Wooley et al. 1999). The weighted average cost of capital was 
computed as 8.9 percent using Eq. (14). The minimum feedstock inventory stored at a plant per month was assumed to be 7 days $\left(12,700\right.$ dry metric tons month $\left.{ }^{-1}\right)$. The economic assumptions related to the base ethanol plant are summarized in Table 3.2. Mill residue purchase price was obtained by consulting with several sawmill owners in the region. The stumpage cost of logging residue was assumed to be $\$ 1 \mathrm{t}^{-1}$ (wet basis) in the base case. All ethanol and electricity produced were assumed to be sold in West Virginia and the bordering states.

Table 3.2. Assumptions for a 1,814 t/day woody biomass-based ethanol plant.

\begin{tabular}{|c|c|}
\hline Parameter & Assumption in the base case \\
\hline Primary product & Fuel ethanol \\
\hline Feedstock requirement (dry weight) $\left(\mathrm{t}^{\mathrm{day}}{ }^{-1}\right)$ & 1,814 \\
\hline Plant life (yr) & 20 \\
\hline Equity proportion $(\%)$ & 40 \\
\hline Cost of Equity ${ }^{a}(\%)$ & 15 \\
\hline Cost of debt ${ }^{\mathrm{a}}(\%)$ & 8 \\
\hline Federal tax $(\%)$ & 39 \\
\hline General plant depreciation ${ }^{\mathrm{b}}(\mathrm{yr})$ & 7 \\
\hline Steam plant depreciation ${ }^{\mathrm{b}}(\mathrm{yr})$ & 20 \\
\hline Ethanol selling price $\left(\$ 1^{-1}\right)$ & 0.55 \\
\hline Electricity value $\left(\$ \mathrm{kWh}^{-1}\right)$ & 0.05 \\
\hline Ethanol yield ${ }^{\mathrm{c}}\left(1 \mathrm{t}^{-1}\right)$ & 290 \\
\hline Excess electricity generated $^{\mathrm{c}}\left(\mathrm{kWh}^{-1}\right.$ ethanol $)$ & 0.46 \\
\hline Capital $\operatorname{cost}^{\mathrm{c}}(\$$ million$)$ & 265 \\
\hline Operation and maintenance cost ${ }^{\mathrm{c}}\left(\$\right.$ million $\left.\mathrm{yr}^{-1}\right)$ & 27.7 \\
\hline Mill residue purchase price $\left(\$ t^{-1}\right)$ & 22 \\
\hline Logging residue stumpage price $\left(\$ t^{-1}\right)$ & 1.00 \\
\hline Storage cost at landings $\left(\$ t^{-1}\right)$ & 0.00 \\
\hline Biomass inventory at plants (dry weight) $\left(\mathrm{t} \mathrm{month}^{-1}\right)$ & 12,700 \\
\hline Usable proportion of logging residue at landings (\%) & 95 \\
\hline Usable proportion of woody biomass at plants $(\%)$ & 95 \\
\hline Dry matter loss due to transportation $(\%)$ & 2 \\
\hline Operating time (days $\mathrm{yr}^{-1}$ ) & 360 \\
\hline
\end{tabular}

Source: ${ }^{a}$ Specca (2009), ${ }^{b}$ Short et al. (1995), ${ }^{\mathrm{c}}$ Adapted from Wooley et al. (1999). 


\subsection{Results and Discussion}

\subsubsection{Base case}

The optimization results of the model are summarized in terms of NPV, optimal plant location, internal rate of return (IRR), and quantity of woody biomass delivered by handling system (Table 3.3). Because the income taxes were negative in the first two years for the cable skidder handling systems (S1 and S2) and in the first year for the grapple skidder handling systems (S3 and S4), zero taxes were charged instead of the negative values. Thus, the NPV were adjusted based on the adjusted taxes accordingly. The adjusted NPV ranged from $\$ 17.28$ million for the cable skidder-chips system (S2) to \$35.54 million for the grapple skidder-chips system (S4) over the plant life of 20 years. IRR is the average annual return earned through the life of an investment. The IRR of the ethanol facility was computed based on a series of cash flows, which averaged 10.46 percent among the four woody biomass handling systems. The net cash flow of the project became positive by the end of $8^{\text {th }}$ year for all systems. The town of Buckhannon, WV, was the optimal location for all systems due to the maximum NPV. Since the investment and operating and maintenance costs were the same for all the feasible sites, Buckhannon was the optimal site because the delivered cost of feedstock was the lowest. Annual ethanol production at the plant was 189 million liters (50 million gallons). Approximately 649 to 748 thousand tons of logging residue (wet basis) and 454 to 552 thousand tons of mill residue (wet basis) would be needed at this location with an average delivered cost of $\$ 56.79$ to $\$ 61.12$ per dry metric ton. 
Table 3.3. Optimization of the woody biomass-based ethanol facility by biomass handling systems (base case).

\begin{tabular}{|c|c|c|c|c|c|}
\hline $\begin{array}{c}\text { Woody } \\
\text { biomass } \\
\text { handling } \\
\text { system }\end{array}$ & $\begin{array}{c}\text { NPV } \\
\text { (\$ million) }\end{array}$ & $\begin{array}{l}\text { Optimal plant } \\
\text { location }\end{array}$ & $\begin{array}{c}\text { IRR after tax } \\
(\%)\end{array}$ & $\begin{array}{c}\text { Quantity of } \\
\text { logging residue } \\
\text { delivered }^{\mathrm{a}}\end{array}$ & $\begin{array}{l}\text { Quantity of } \\
\text { mill residue } \\
\text { delivered }^{\mathrm{a}}\end{array}$ \\
\hline S1 & 17.61 & $\begin{array}{c}\text { Buckhannon, } \\
\text { WV }\end{array}$ & 9.96 & 649 & 552 \\
\hline S2 & 17.28 & $\begin{array}{c}\text { Buckhannon, } \\
\text { WV }\end{array}$ & 9.94 & 654 & 547 \\
\hline S3 & 34.42 & $\begin{array}{c}\text { Buckhannon, } \\
\text { WV }\end{array}$ & 10.93 & 734 & 469 \\
\hline S4 & 35.54 & $\begin{array}{c}\text { Buckhannon, } \\
\text { WV }\end{array}$ & 10.99 & 748 & 454 \\
\hline
\end{tabular}

\subsubsection{Ethanol production cost}

Ethanol production cost includes the costs associated with capital recovery, operation and maintenance, raw materials (excluding woody biomass), and woody biomass delivered cost. The average production cost of woody biomass-derived ethanol varied from US $\notin 53.17$ to US $\notin 54.70$ $1^{-1}$ without consideration of electricity credit. Feedstock (woody biomass) and capital recovery were the two major cost components, accounting for about 39 percent and 33 percent of the total production cost, respectively. The complexity of producing ethanol from woody biomass compared to corn-based ethanol was attributable to the higher capital cost (Greer 2007). This conversion technology requires more costly equipment and more processing steps to produce ethanol (Bullis, 2006). In this study, the fixed operating costs (including labor/supervision, general and direct overhead, maintenance, and insurance/property taxes) and variable operating costs (including all the raw materials except woody biomass, water consumption, and waste disposal) accounted for 16.56 percent and 10.53 percent of the total cost, respectively. Wooley et al. (1999) estimated that $1.76 \mathrm{kWh}$ electricity can be generated along with the production of 
3.785 liter (1 gallon) of ethanol. Therefore, the production cost of ethanol would be in the range from US $\varnothing 50.85$ to US $\varnothing 52.381^{-1}$ after deducting the electricity credit of US $\notin 2.321^{-1}$ given the electricity price of US $₫ 5 \mathrm{kWh}^{-1}$.

\subsubsection{Sensitivity analyses}

$\underline{N P V \text { and IRR vs. ethanol price }}$

Ethanol price is critical to the evaluation of a cellulosic ethanol facility, and can have great impacts on NPV and IRR. The ethanol price is relatively volatile and subject to changes in the wholesale price of unleaded regular gasoline with additional volatility due to local, regional and national supply and demand for ethanol (BBI International 2002). Current relatively lower oil prices have reduced the demand for ethanol, and the spot prices of ethanol are trending down in line with the softness in energy markets. The NPV and IRR were estimated in terms of various ethanol prices by different woody biomass handling systems (Figure 3.2). The grapple skidder handling systems (S3 and S4) presented higher NPV and IRR than the cable skidder handling systems (S1 and S2). The magnitude of the NPVor IRR change was approximately proportional to the change of ethanol price for all systems. If ethanol price decreased US $\notin 2.51^{-1}$, the NPV of the base case plant ( 50 million gallons $\mathrm{yr}^{-1}$ ) would decrease by $\$ 27.60$ million and the IRR would decrease 1.69 percent. 


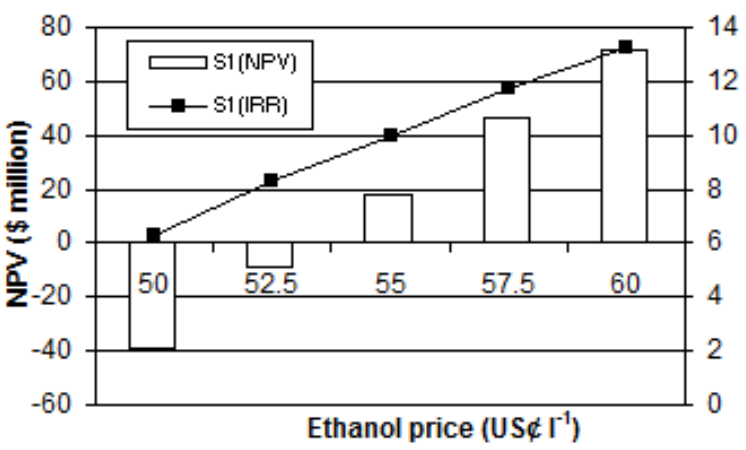

(a)

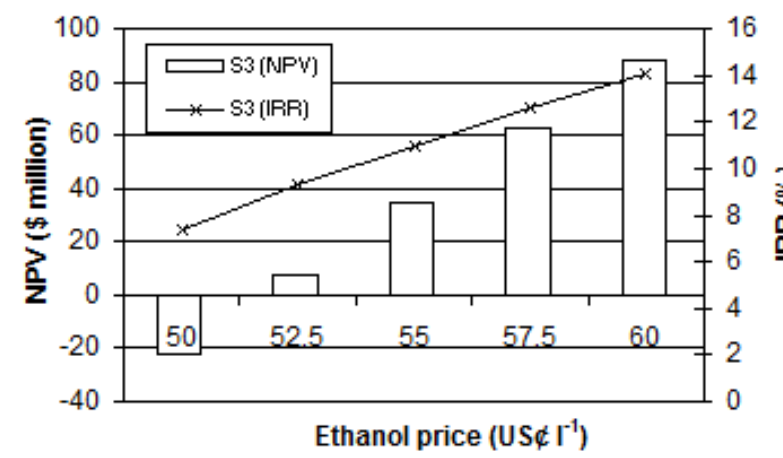

(c)

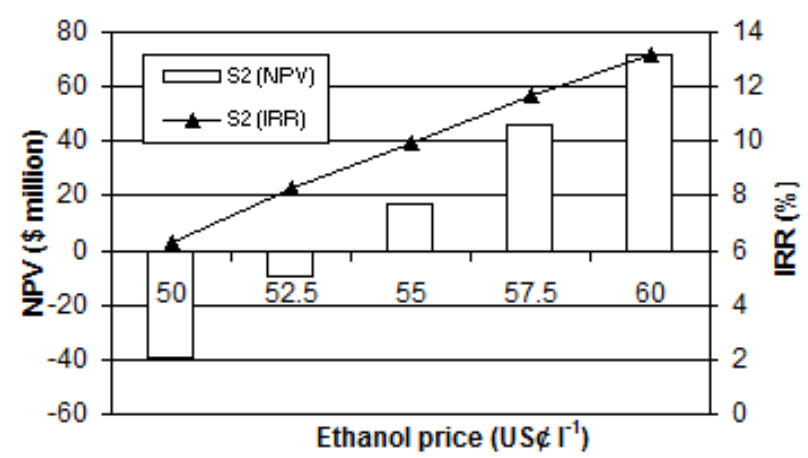

(b)

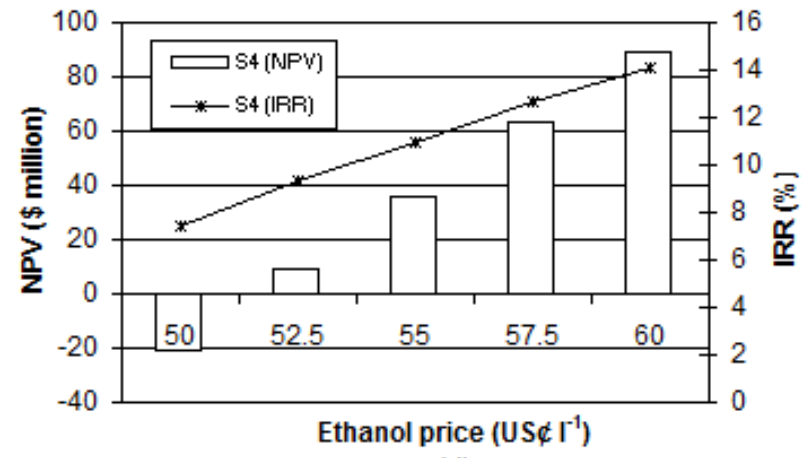

(d)

Figure 3.2. Net present value and internal rate of return vs. ethanol price.

\section{Ethanol production cost vs. feedstock supply}

The total feedstock was estimated to be 3.27 million dry metric tons per year in the state of West Virginia and some bordering counties of West Virginia's neighboring states (USDA-FS 2008). With the assumptions that 65 percent of logging residue on harvested sites with a slope of 35 percent or less and 40 percent of mill residue are available, the usable feedstock could be up to 1.70 million dry metric tons. Given the plant capacity of 1,814 dry metric tons per day in the base case, the feedstock needed annually is approximately 0.70 million dry tons, or 41 percent of the total available. The average production cost of ethanol decreased as the available residue increased (Figures 3.3a, 3.3b). There were significant differences among the woody biomass handling systems in terms of ethanol production cost. The grapple skidder systems (S3 and S4) tended to have lower production cost compared to the cable skidder systems. Logging residue 
had greater impacts on ethanol production cost in contrast with mill residue because more logging residue could be delivered to the utilization facility. The production cost of ethanol increased as the stumpage cost of logging residue increased (Figure 3.3c). For every US\$1 $\mathrm{t}^{-1}$ increase in the stumpage cost, the production cost would increase US $\notin 0.341^{-1}$ for the cable skidder-loose residue system (S1), US $\notin 0.351^{-1}$ for the cable skidder chips system (S2), US $\notin 0.37$ $1^{-1}$ for the grapple skidder-loose residue system (S3), and US $\notin 0.401^{-1}$ for the grapple skidderchips system (S4). If the purchase price of mill residue increased from US\$22 $\mathrm{t}^{-1}$ (base case) to US\$30 $t^{-1}$, the production cost would increase 2.9-4.0 percent accordingly from the base case depending on the biomass handling system used (Figure 3.3d). Note that the production cost increased at a decreasing rate as mill residue purchase price increased among the systems. Since both logging residue and mill residue were possible feedstock for the ethanol plant, increasing mill residue purchase price will lead to more utilization of logging residue. If mill residue purchase price were high enough, no mill residue would be used and all the feedstock entering into the plant would be logging residue. 


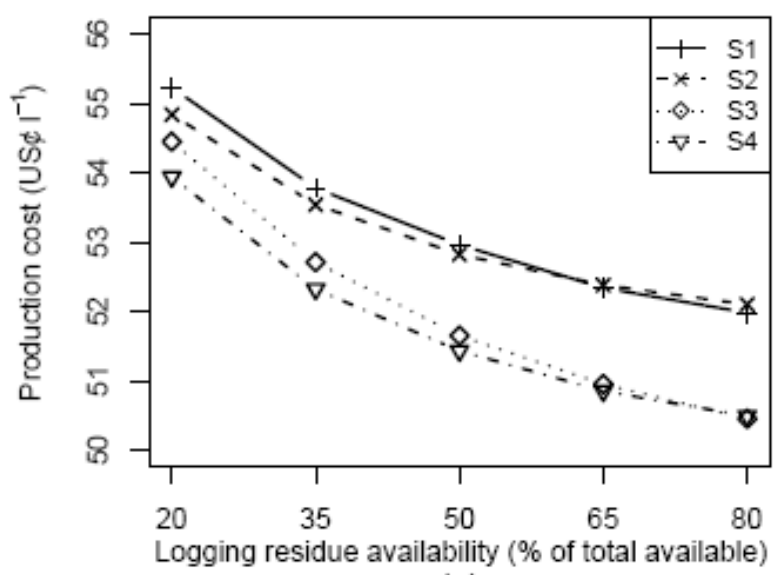

(a)

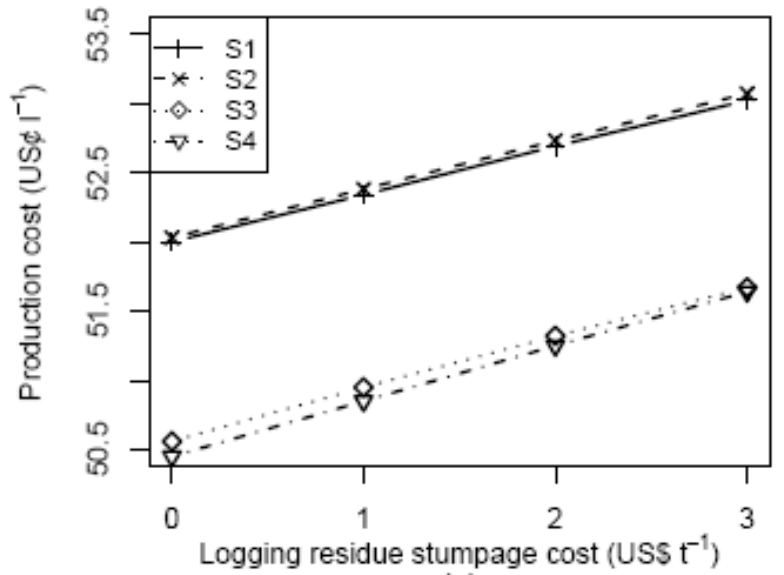

(c)

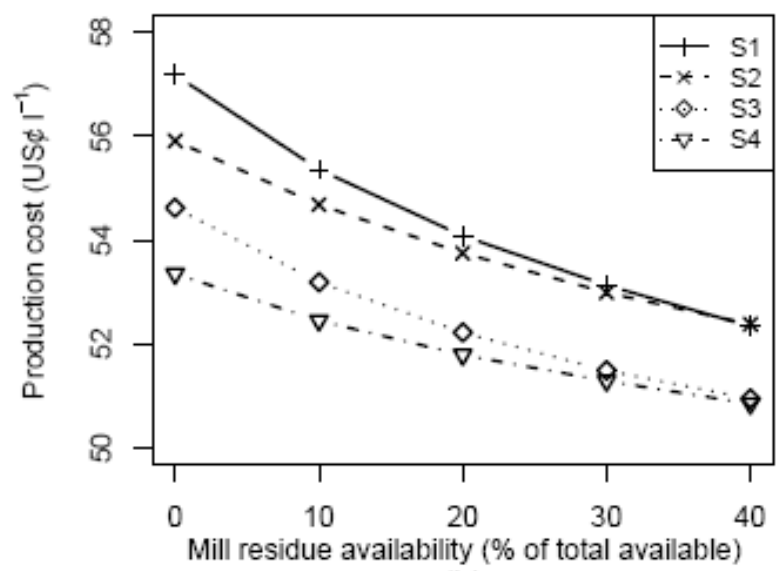

(b)

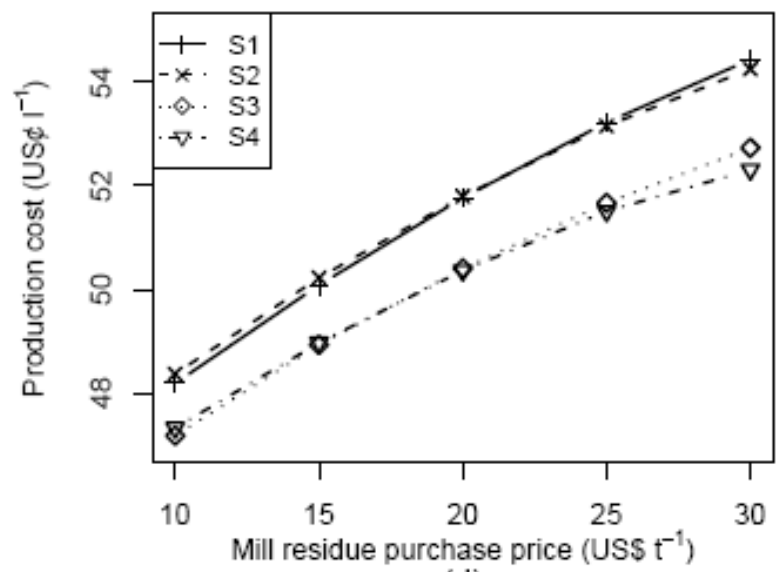

(d)

Figure 3.3. Ethanol production cost vs. feedstock availability and cost by system (wet basis).

\section{Ethanol production cost vs. capital cost}

A cellulosic ethanol plant is a capital-intensive investment. To date, there are no commercial cellulosic ethanol plants in production in North America. Only a few small demonstration biorefineries are producing ethanol from cellulosic feedstock including Iogen Corporation (Canada), the world's first cellulosic ethanol producer, and Verenium (U.S.), the first cellulosic ethanol plant in the U.S. (Fehrenbacher 2008, Deutscher 2009). In this study, the total scale-adjusted investment estimation of \$265 million (US $\propto 1391^{-1}$ of ethanol) using Eq. (5) for a first-of-a-kind cellulosic ethanol plant was based on a report published by the National Renewable Energy Laboratory (NREL) (Wooley et al. 1999) which was completed in 
conjunction with a commercial ethanol plant developer. The production cost of ethanol increased proportionally as the total capital cost increased (Figure 3.4a). If the total capital cost increased 5 percent compared to the base case, the production cost of ethanol would increase 1.70-1.77 percent, depending on the biomass handling system used. If the total capital cost increased 10 percent, the ethanol production cost would increase 3.42-3.54 percent among the four handling systems.

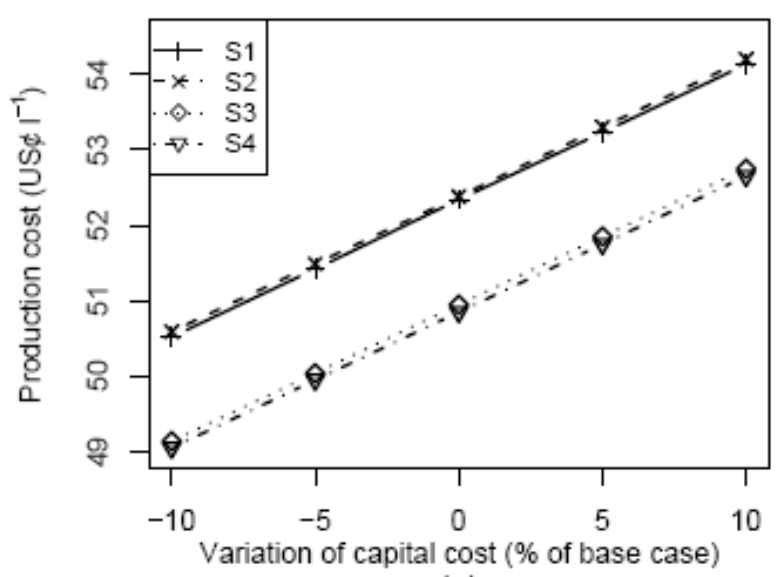

(a)

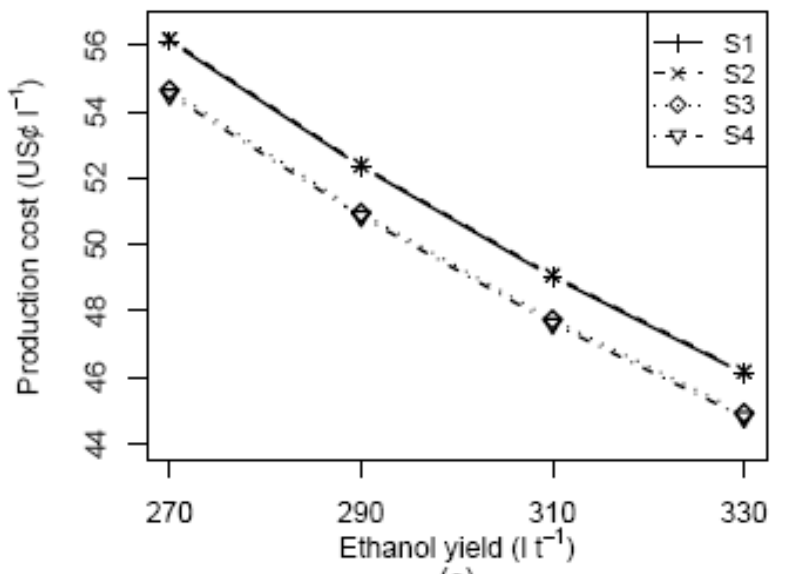

(c)

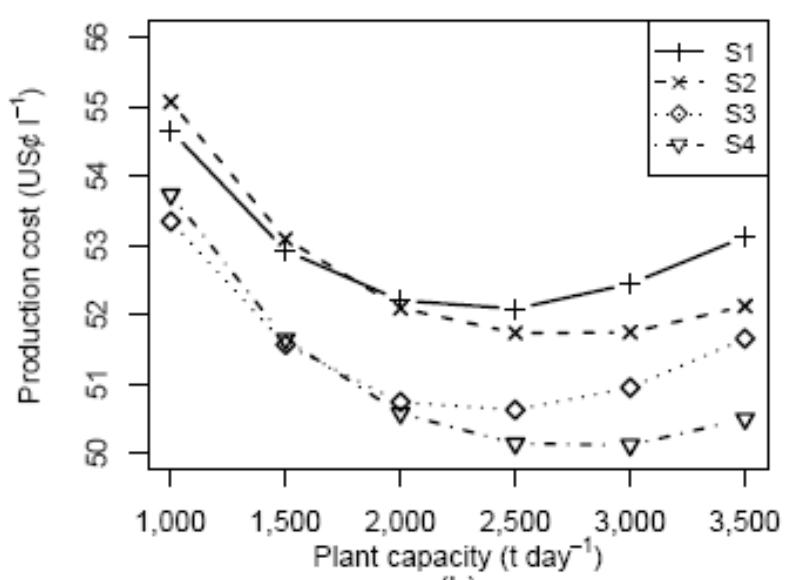

(b)

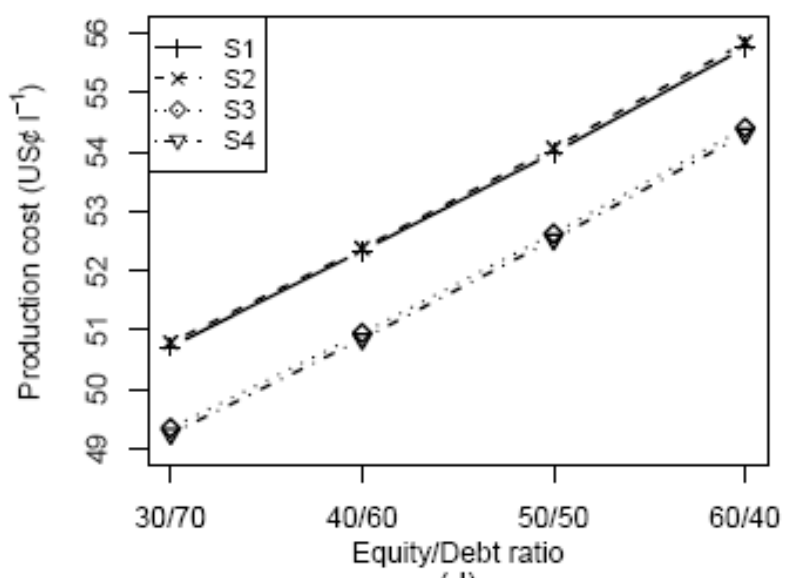

(d)

Figure 3.4. Ethanol production cost vs. plant assumptions by system (dry weight).

\section{Ethanol production cost vs. plant capacity}

The average production cost of ethanol decreased as the use for woody biomass at plants increased (Figure 3.4b). As the plant scale increased, the average cost related to plant investment 
decreased due to economy of scale. However, the marginal cost associated with transportation increased because the plant has to source feedstock from a greater distance. The production cost of ethanol reached the minimum when the use of woody biomass increased to 2,400 dry metric tons per day for $\mathrm{S} 1$ and $\mathrm{S} 3$, or 2,800 dry metric tons per day for S2 and S4. After that, the production costs went up again. At the demand level of 2,400 dry metric tons per day, the production cost in $\mathrm{S} 1$ and $\mathrm{S} 3$ decreased 0.59 percent compared to the base case. The production cost in S2 and S4 decreased 1.45 percent compared to the base case when the plant capacity approached 2,800 dry metric tons per day. The cable skidder handling systems (S1 and S2) always presented higher production cost compared to the grapple skidder handling systems (S3 and S4).

\section{Ethanol production cost vs. ethanol yield}

Technologies that convert wood to cellulosic ethanol are in varying stages of development and commercialization (Benjamin et al. 2009). The ethanol yield from one metric ton of dry woody biomass could vary from 208 to 500 liters depending on conversion technology and other operational conditions. The co-current dilute acid prehydrolysis and enzymatic hydrolysis developed by the NREL was considered as one of the available conversion methods and the ethanol yield could be 2831 from one dry metric ton of woody biomass (Wooley et al. 1999). The change of the average production cost of ethanol was assessed according to the ethanol yield (Figure 3.4c). For example, the average production cost would decrease US $₫ 3.31^{-1}$ for every 20 liter per ton increase in yield.

\section{Ethanol production cost vs. project finance}

Project financing and funding are considered by many to be a major obstacle to the development and commercialization of the ethanol industry (Solomon et al. 2007). The structure 
of project financing can have a significant impact on the viability of a cellulosic ethanol project due largely to higher investment cost (Graf and Koehler 2000). Agribusiness lenders with Farm Credit Services of America suggest that the equity-to-asset ratio for an ethanol plant should be at least 40 percent (CFDC and NEB 2006), which means that investors should own no less than 40 percent of the total value of the plant and inventory. Several equity/debt ratios were analyzed in order to compare the ethanol production cost (Figure 3.4d). It was shown that the lower equity proportions resulted in lower production costs for all systems because of the lower discount rate (WACC) for the ethanol project and the capital cost per liter of ethanol. Compared to the base case financing assumption (40/60 equity/debt ratio), if this ratio was down to 30/70, the production cost of ethanol would decrease 3.10 percent on average for all systems. However, the risk associated with this plant would be higher because of more debt. If the equity/debt ratio increased to 50/50, the ethanol production cost would increase 3.25 percent.

\subsubsection{Other implications}

Security of feedstock supply

The stabilization of feedstock supply is critical to the success of a woody biomass-based facility. The increased regulations over forest practices, such as best management practices, and certifications, often increase woody biomass harvesting costs and limit resource availability in the short term (Benjamin et al. 2009). Logging residue has been considered as an under-utilized resource with limited value. As the biomass market develops for ethanol or other bioproducts, more biomass would be needed and a higher stumpage cost of logging residue would be inevitable. In considering the future availability of mill residue, several issues should be considered. Since mill residue is a by-product of lumber production, its availability depends on other markets, as demonstrated recently with the corresponding decline in production of mill 
residue due to the housing slowdown (U.S. Census Bureau 2009). The supply of mill residue in the central Appalachian region remains more uncertain because of mill closures and long-term production constraints (Dye 2009). The utilization of woody biomass for biofuels will also confront competition from other uses such as pellet fuel and boiler fuel, which could increase the price of woody biomass. To secure the supply chain of woody biomass, it is essential to find niche supply markets for wood residues through long-term contracts, or collaborative relationships with landowners and major forest products companies.

\section{Government policies}

Government subsidies will initially be essential to the market success of woody biomassbased facilities. Without government subsidies, ethanol producers would have to sell their products at current market price. For example, in our case, the difference between the market price and the assumed value could be US $\notin 5.41^{-1}$. Government and other support mechanisms have been a consistent and essential part of the U.S. ethanol industry (Solomon et al. 2007). Various federal incentive programs have been designed to encourage the production and utilization of ethanol and other biofuels such as Excise Tax Incentives, Income Tax Credit for Alcohol Fuels, Ethanol Production Incentive, Income Tax Credit, Income Tax Credit for Small Ethanol Producers, and others. The most significant subsidy is the federal Volumetric Ethanol Excise Tax Credit (VEETC) (mainly for corn ethanol), which was established in 2004 as a US $\varnothing$ $13 \mathrm{l}^{-1}$ payment to gasoline blenders which will end in 2010. The 2008 Farm Bill reduced the credit to US $\notin 121^{-1}$ and the credit for cellulosic ethanol was set at US $\notin 271^{-1}$ through 2012. At the current spot price of US $\notin 49.61^{-1}$ (DTN Ethanol Center, 2009), the cellulosic ethanol plant in central Appalachia would not be economically viable without the government subsidy. 


\section{Ethanol market}

West Virginia is a moderate ethanol consumer with annual consumption of 542,620 barrels (22.79 million gallons) (U.S. Department of Energy 2009). The bordering states such as Ohio, Virginia, and Pennsylvania consumed approximately 11 million barrels of ethanol in 2005 (USDOE 2009). Most ethanol consumed in this region is from the Midwest corn-belt (Tyner, 2008). Due to the transport infrastructure bottleneck, ethanol availability is limited in the eastern states (Tyner 2008). A potential cellulose ethanol production of 50 million gallons in West Virginia could help meet the state's own needs as well as supply the markets in the neighboring states. The business will also stimulate economic development and create job opportunities in urban and rural communities in the region.

\subsection{Conclusions}

The economic model developed can be used to assess the location of a woody biomassbased ethanol facility in the central Appalachian region and to evaluate the economic viability under certain resource, capacity, and other constraints. This study differs from prior studies in several aspects. First, the delivered cost of woody biomass was computed based on a series of logistic constraints including supply and demand. This cost would change as the factors such as biomass availability, purchase price, and demand level at the ethanol plant changed. Second, the NPV was calculated in consideration of the income taxes, while most studies only considered revenue and fixed and variable operating costs. The NPV estimated using the mixed integer programming model provides a deep insight on the economic viability of the cellulose ethanol facility. Third, the model can deal with optimizing logistical decision-making when linked to feedstock requirements, collection, delivery, and production issues. Since this is a generalized model, it can also be applied to the other regions. 
The application results of the base case showed that the optimal location for the woody biomass-based ethanol plant should be in Buckhannon, West Virginia, which is surrounded by abundant woody biomass resources. The NPV varied from $\$ 17.28$ million for the cable skidderchips system (S2) to $\$ 35.54$ million for the grapple skidder-chips system (S4) with an after-tax discount rate of 8.9 percent over the plant life. The internal rate of return averaged 10.46 percent among the four woody biomass handling systems. The net cash flow of the plant became positive by the end of the $8^{\text {th }}$ year. The primary revenue source of the facility came from the sale of ethanol and electricity, without considering the small ethanol producer tax credit. The production cost of ethanol varied from US $\varnothing 50.851^{-1}$ for the grapple skidder-chips system (S4) to US $\notin 52.38$ $1^{-1}$ for the cable skidder-chips system (S2). Sivers and Zacchi (1996) reviewed the economy of ethanol production from lignocellulosic material and found that the variation in the ethanol production cost is large, from US $\notin 18$ to US $\phi 1511^{-1}$. The wide variation in ehtanol production cost can be explained by different assumptions made in the technical and economic calculations, such as raw materials used, the type of process utilized, and the design of the process. Sensitivity analyses indicated that the production cost of ethanol in the facility in the central Appalachian hardwood region heavily depended upon biomass availability, plant investment and capacity, ethanol yield, and financial structure.

This study provides a solid base for further research in assessing the social and environmental issues of the woody biomass-based ethanol facility. More efforts are necessary to assess the detailed plant configuration including equipment, utilities, and labor availability. Necessary permits related to air emissions and water pollution controls required for the ethanol facility in the designated location should be considered as well. 


\section{References}

BBI International. 2002. Feasibility study for bioethanol co-location with a coal fired power plant. National Renewable Energy Laboratory, Golden, CO, Report NREL/SR-51032999, pp. 82.

Bullis, K. 2006. Making ethanol from wood chips (http://www.technologyreview.com/energy/17799/).

Benjamin, J., Lilieholm, R.J., and Damery, D. 2009. Challenges and opportunities for the Northeastern forest bioindustry. Journal of Forestry April/May, 125-131.

Blagojevich, R., Scott, D.P., and Lavin, J. 2006. Building an ethanol plant in Illinois, a guide to permit requirements, funding opportunities and other considerations (http://www.epa.state.il.us/agriculture/building-an-ethanol-plant.pdf).

Bragonje, R., Grushecky, S., Spong, B., Slahor, J., and Osborn, L. 2006. West Virginia wood byproducts available and needed. West Virginia University, Morgantown, WV. P. 10-33.

CFDC (Clean Fuels Development Coalition) and NEB (Nebraska Ethanol Board). 2006. A guide for evaluating the requirements of ethanol plants (http://www.neethanol.org/industry/evalreq.pdf).

Cusack, C. 2008. Harnessing the power of local wood energy. (http://www.forestguild.org/publications/research/2008/Local_Wood_Energy.pdf).

DTN Ethanol Center. 2009. Weekly ethanol rack prices (http://www.dtnethanolcenter.com/index.cfm?show=10\&mid=32) (accessed July 28, 2009).

Deutscher, H. 2009. Cellulosic ethanol: ready, set, go. Ethanol Producer Magazine (July) (article 9). 
Dye, R. 2009. Challenging times. The $23^{\text {rd }}$ Annual A. B. Brooks Forestry Symposium, Charleston, WV, February 6-7, 2009.

Dornburg, V., and Faaij, A.P.C. 2001. Efficiency and economy of wood-fired biomass energy systems in relation to scale regarding heat and power generation using combustion and gasification technologies. Biomass and Bioenergy 21: 91-108.

Fehrenbacher, K. 2008. Verenium opens cellulosic ethanol demo plant (http://earth2tech.com/2008/05/28/verenium-opens-cellulosic-ethanol-demo-plant/).

Greer, D. 2007. Realities, opportunities for cellulose ethanol. Biocycle 48(1), p.46.

Graf, A., and Koehler, T. 2000. Oregon cellulose-ethanol study-An evaluation of the potential for ethanol production in Oregon using cellulose-based feedstocks (http://www.ethanolgec.org/information/briefing/20a.pdf).

Graham, R.L., English, B.C., and Noon, C.E. 2000. A Geographical Information System-based modeling system for evaluating the cost of delivered energy crop feedstock. Biomass and Bioenergy 18(4), 309-329.

Grushecky, S., McGill, D., and Anderson, R.B. 2006. Inventory of wood residues in Southern West Virginia. Northern Journal of Applied Forestry 23(1), 47-52.

Kärhä, K. and Vartiamäki, T. 2006. Productivity and costs of slash bundling in Nordic conditions. Biomass and Bioenergy 30, 1043-1052.

Kerstetter, J. D. and Lyons, J. K. 2001. Logging and Agricultural Residue Supply Curves for the Pacific Northwest. Washington State University Energy Program. Olympia, WA. DEFC01-99EE50616. 24 p.

Kaylen, M., Vandyne, D.L., Choi, Y.S., and Blase, M. 2000. Economic feasibility of producing ethanol from lignocellulosic feedstocks. Bioresource Technology 72(1), 19-32. 
Li, Y., Wang, J., Miller, G., and McNeel, J. 2006. Production economics of harvesting smalldiameter hardwood stands in central Appalachia. Forest Products Journal 56(3), 81-86.

Mapemba, L.D. 2005. Cost to deliver lignocellulosic biomass to a biorefinery. Ph.D. Dissertation. Oklahoma State University, Stillwater, OK. pp. 51-71.

McMenamin, J. 1999. Financial Management. Routledge, London.

MyRatePlan.com. 2008. Distance calculator-How far is it between two cities? ( http://www.myrateplan.com/how_far/).

Miyata, E.S. 1980. Determining fixed and operating costs of logging equipment. USDA For. Serv. Gen. Tech. Rept. NC-55.

Noon, C.E., Zhan, F.B., and Graham, R.L. 2002. GIS-based analysis of marginal price variation with an application in the identification of candidate ethanol conversion plant locations. Networks and Spatial Economics, 2(1), 79-93.

Perlack, R.D., Wright, L.L., Turhollow, A.F., Graham, R.L., Stokes, B.J., and Erbach, D.C. 2005. Biomass as feedstock for a bioenergy and bioproducts industry: The technical feasibility of a billion-ton annual supply. U.S. Department of Energy and U.S. Department of Agriculture, pp. 78.

Sivers, M. V. and Zacchi, G. 1996. Ethanol from lignocellulosics: a review of the economy. Bioresource Technology 56, 131-140.

Short, W., Packey, D. J., and Holt, T. 1995. A Manual for the Economic Evaluation and Energy Efficiency and Renewable Energy Technologies, National Renewable Energy Laboratory, Golden, CO, Report TP-462-5173, pp. 19-21.

Solomon, B.D., Barnes, J.R., and Halvorsen, K.E. 2007. Grain and cellulosic ethanol: history, economics, and energy policy. Biomass and Bioenergy 31, 416-425. 
Specca, D. 2009. Bioenergy from food waste and farm grown crops.

(http://www.rci.rutgers.edu/ sifood/bioenergy.ppt).

Tyner, W.E. 2008. The US ethanol and biofuels boom: its origins, current status, and future prospects. Bioscience 58(7), 646-653.

Taha, H.A. 2006. Operations Research: An Introduction ( $8^{\text {th }}$ edition). Pearson Prentice Hall, New Jersey, NJ, 704p.

Tyner, W. E. and Taheripour, F. 2007. Future biofuels policy alternatives. In proceedings of Biofuels, Food \& Feed Tradeoffs. St. Louis, Missouri., 12-13 April 2007. Edited by Outlaw, J.L., Texas A\&M University, College Station, TX, Duffield, J.A., USDA, Washington, DC, and Ernstes, D.P. Texas A\&M University, College Station, TX, pp.10.

Taheripour, F. and Tyner, W. E. 2008. Ethanol policy analysis-what have we learned so far? Choices: The magazine of Food, Farm \& Resource Issues 23(3), 6-11.

Tembo, G., Epplin, F., and Huhnke, R.R. 2003. Integrative investment appraisal of a lignocellulosic biomass-to-ethanol industry. Journal of Agricultural and Resource Economics 28(3), 611-633.

Ulrich, G. D. 1984. A Guide to Chemical Engineering Process Design and Economics, Wiley, New York.

U.S. Census Bureau, 2009. Lumber production and mill stocks-2008, MA321T(08)-1 (http://www.census.gov/cir/www/321/ma321t.html).

U.S. Department of Energy. 2009. State energy summary (http://apps1.eere.energy.gov/states/state information.cfm).

U.S. Department of Agriculture - Forest Service (USDA-FS). 2008. Timber products output Mapmaker version 1.0 (http://ncrs2.fs.fed.us/4801/fiadb/rpa_tpo/wc_rpa_tpo.ASP). 
Volker, R., Schaaf, H., and Tachkov, P. 2009. Evaluation of research and technology projects: a status quo analysis of technology-intensive companies. International Journal of Technology Intelligence and Planning Issue 5, 165-190.

Wang, J., Long, C., and McNeel, J. 2004. Production and cost analysis of a feller-buncher and grapple skidder in central Appalachian hardwood forests. Forest Products Journal 54(12), 159-167.

West Virginia Division of Forestry (WVDOF). 2006. West Virginia Logging Sediment Control Act - 2006 Statistics. West Virginia Division of Forestry, Charleston, WV, USA.

Wang, J., Grushecky, S., and McNeel, J. 2006. Biomass Resources, Uses, and Opportunities in West Virginia. West Virginia University, Biomaterials Center, Morgantown, WV, USA.

Wooley, R., Ruth, M., Sheehan, J., Ibsen, K., Majdeski, H., and Galvez, A. 1999. Lignocellulosic biomass to ethanol process design and economics utilizing co-current dilute acid prehydrolysis and enzymatic hydrolysis current and futuristic scenarios. National Renewable Energy Laboratory, Golden, Colorado. NREL/TP-580-26157.

Wu, J., Wang, J., and McNeel, J. 2008. Economic modeling of woody biomass utilization for biofuels: a case study in West Virginia. In: Proceedings of the 31st Annual Meeting of Council on Forest Engineering, June 22-25, 2008, Charleston, SC. P. 206-218.

Zerbe, J. I. 1991. Liquid fuels from wood-ethanol, methanol, diesel. World Resource Review 3, 406-414. 


\section{Appendix 3.A. Sets, parameters, and variables}

Table 3.A1. Sets and descriptions.

\begin{tabular}{|c|c|}
\hline Set & Description \\
\hline$G$ & Products; $g=\{$ ethanol, electricity $\}$ \\
\hline$H$ & $\begin{array}{l}\text { Woody biomass handling systems; } h=\{\text { cableskidder_looseresidue, } \\
\text { cableskidder_chips, grappleskidder_looseresidue, grappleskidder_chips }\}\end{array}$ \\
\hline$I$ & $\begin{array}{l}\text { Woody biomass supply locations; } i=\{\text { All counties in West Virginia and some } \\
\text { counties in the bordering states }\}\end{array}$ \\
\hline$J$ & $\begin{array}{l}\text { Possible plant locations; } j=\{\text { Beaver, Belington, Bluefield, Buckhannon, } \\
\text { Holden, Kenna, Millwood, Morgantown, Oak Hill, Point Pleasant, and } \\
\text { Williamson }\}\end{array}$ \\
\hline$K$ & Facility type; $k=\{$ general_plant, steam_plant $\}$ \\
\hline$M$ & Months, $m=\{1,2, \ldots, 12\}$ \\
\hline$N$ & Set of project year indices, $n=\{1,2, \ldots, N\}$ \\
\hline$S$ & Set of breakpoints, $s=\{0,1, \ldots, 9\}$ \\
\hline
\end{tabular}


Table 3.A2. Parameters and descriptions.

\begin{tabular}{|c|c|}
\hline Parameter & Description \\
\hline$a_{s}$ & $\begin{array}{l}\text { Breakpoints over the quantity of annually delivered logging residue from } \\
\text { supply county } i \text { to plant } j\end{array}$ \\
\hline$A L F A_{\text {ih }}$ & $\begin{array}{l}\text { A parameter associated with system } h \text { at supply location } i \text {, } \\
A L F A_{i h}=\{0,1\}\end{array}$ \\
\hline$B P_{i}$ & $\begin{array}{l}\text { Proportion of logging residue available for extraction at supply location } \\
i(\%)\end{array}$ \\
\hline$B I V_{i}$ & Volume of logging residue at supply location $i(\mathrm{t})$ \\
\hline$B V S_{i}$ & $\begin{array}{l}\text { Volume of logging residue on forest lands with a slope of } 35 \% \text { or less at } \\
\text { supply location } i(\mathrm{t})\end{array}$ \\
\hline$C_{n}$ & Capital depreciations at the $n^{\text {th }}$ year $(\$)$ \\
\hline$C F_{k n}$ & Depreciation cost of facility type $k$ at the $n^{\text {th }}$ year (\$) \\
\hline$C F D_{k n}$ & Declining balance depreciation cost of facility type $k$ at the $n^{\text {th }}$ year $(\$)$ \\
\hline$C F S_{k n}$ & Straight line depreciation cost of facility type $k$ at the $n^{\text {th }}$ year (\$) \\
\hline$C R_{k n}$ & Unrecovered capital cost of facility type $k$ at the $n^{\text {th }}$ year (\$) \\
\hline$C S_{h}$ & In-woods chipping cost associated with handling system $h\left(\$ \mathrm{t}^{-1}\right)$ \\
\hline$C P_{h}$ & Chipping cost at a plant associated with system $h\left(\$ \mathrm{t}^{-1}\right)$ \\
\hline CAPACITY & $\begin{array}{l}\text { Plant capacity in terms of woody biomass required (dry weight) }\left(\mathrm{t}_{\text {day }}{ }^{-1}\right) \text {, } \\
\text { CAPACITY }=1,814 \text { (base case). }\end{array}$ \\
\hline CAPACITY & $\begin{array}{l}\text { Production capacity of a known woody biomass-based plant (dry weight) } \\
\left(\mathrm{t} \text { day }^{-1}\right), \text { CAPACITY }_{0}=2,000 .\end{array}$ \\
\hline$D_{i j}$ & One-way over-the-road distance between supply location $i$ to plant $j(\mathrm{~km})$ \\
\hline$E X T_{m}$ & $\begin{array}{l}\text { Limitation of logging residue extracted in month } m \text { as a percentage of the } \\
\text { whole year }(\%)\end{array}$ \\
\hline$F C_{s}$ & The slope of the $\mathrm{s}^{\text {th }}$ line segment in the range $\left(a_{s-1}, a_{s}\right)$ \\
\hline$H C_{h}$ & Logging residue extraction cost for handling system $h\left(\$ \mathrm{t}^{-1}\right)$ \\
\hline$L C_{h}$ & Loading cost of woody biomass associated with system $h\left(\$ \mathrm{t}^{-1}\right)$ \\
\hline$M C$ & Purchase price of mill residue $\left(\$ \mathrm{t}^{-1}\right)$ \\
\hline$M T$ & Mill residue transportation cost rate $\left(\$ \mathrm{t}^{-1} \mathrm{~km}^{-1}\right)$ \\
\hline$M I V_{i}$ & Volume of mill residue at supply location $i(\mathrm{t})$ \\
\hline$M P_{i}$ & Mill residue availability at supply location $i(\%)$ \\
\hline MS & Marshall \& Swift index in the initial project year \\
\hline$M S_{0}$ & Marshall \& Swift index in the historical year \\
\hline$M N B I N$ & Minimum biomass inventory at a plant (t), $M N B I N=12,700$ (base case). \\
\hline$N R_{k}$ & Recovery period of facility type $k(\mathrm{yr})$ \\
\hline$N L_{i}$ & Number of loggers in supply location $i$ \\
\hline$N M_{h}$ & Average number of extraction machines that a logging crew owns \\
\hline
\end{tabular}


Table 3.A2-Parameters and descriptions (continued).

\begin{tabular}{|c|c|}
\hline Parameter & Description \\
\hline$O M_{n}$ & Annual operation and maintenance costs $(\$), O M_{n}=O M$ for all $n$ \\
\hline$P_{g}$ & $\begin{array}{l}\text { Whole sale price per unit of product } g\left(\$ 1^{-1} \text { for ethanol and } \$ \mathrm{kWh}^{-1} \text { for }\right. \\
\text { electricity })\end{array}$ \\
\hline$P D_{h}$ & Productivity of extraction machine associated with system $h\left(\mathrm{t} \mathrm{h}^{-1}\right)$ \\
\hline$P V I_{n}$ & Present value of $\$ 1$ at the $n^{\text {th }}$ year \\
\hline$r_{e}$ & Cost of equity (\%) \\
\hline$r_{d}$ & Cost of debt (\%) \\
\hline$R S_{i}$ & $\begin{array}{l}\text { One half of the furthest straight-line distance (e.g., distance from the east } \\
\text { to north) of supply county } i(\mathrm{~km})\end{array}$ \\
\hline$S C$ & Logging residue storage cost at landings $\left(\$ \mathrm{t}^{-1}\right)$ \\
\hline$S P$ & Stumpage price of logging residue $\left(\$ \mathrm{t}^{-1}\right)$ \\
\hline$t$ & Federal tax rate applied to the ethanol facility (\%) \\
\hline$T C_{i j h}$ & $\begin{array}{l}\text { Round trip transportation cost from location } i \text { to plant } j \text { for system } h(\$ \\
\left.\mathrm{t}^{-1}\right)\end{array}$ \\
\hline$T_{h}$ & Off-highway transportation cost rate for system $h\left(\$ \mathrm{t}^{-1} \mathrm{~km}^{-1}\right)$ \\
\hline$T P C_{j}$ & Plant investment cost at location $j(\$)$ \\
\hline$T P C_{0}$ & Investment cost of a known woody biomass-based ethanol plant (\$) \\
\hline$w_{e}$ & Equity proportion of the project (\%) \\
\hline WACC & Weighted average cost of capital (\%) \\
\hline$\sigma$ & Moisture content of woody biomass (\%) \\
\hline$\eta_{g}$ & $\begin{array}{l}\text { Conversion factor for product } g \text { from one dry metric ton of woody } \\
\text { biomass }\end{array}$ \\
\hline$\lambda$ & Monthly productive time per machine (h) \\
\hline$\delta$ & Dry matter loss due to woody biomass transportation (\%) \\
\hline$\theta_{i}$ & Usable proportion of woody biomass in the fields at location $i(\%)$ \\
\hline$\phi$ & Usable proportion of woody biomass at a plant (\%) \\
\hline
\end{tabular}


Table 3.A3. Variables and descriptions.

\begin{tabular}{ll}
\hline Variable & Description \\
\hline$\beta_{j}$ & A binary variable associated with plant $j, \beta_{j}=\{0,1\}$ \\
$q_{j g m}$ & Quantity of product $g$ produced in month $m$ at plant location $j$ \\
$F_{n}$ & Annual feedstock cost $(\$), F_{n}=F$ for all $n$ \\
$L C T$ & Under-estimated transportation cost $(\$)$ \\
$R_{n}$ & Annual revenue from the sale of products $(\$), R_{n}=R$ for all $n$ \\
$T_{n}$ & Income taxes at the $n^{\text {th }}$ year $(\$)$ \\
$N P V$ & Net present value of the plant $(\$)$ \\
$\Omega$ & Total investment cost at all feasible sites $(\$)$ \\
$x h_{i h m}$ & Quantity of logging residue extracted in month $m$ at supply location $i$ \\
$x m_{i j m}$ & using system $h(\mathrm{t})$ \\
$x p p_{j m}$ & Quantity of mill residue delivered from supply location $i$ to plant $j$ in \\
$x p s_{i h m}$ & month $m(\mathrm{t})$ \\
$x s_{i h m}$ & Quantity of woody biomass processed at plant $j$ in month $m(\mathrm{t})$ \\
$x s n_{i h m}$ & Quantity of logging residue entered into storage at supply location $i$ in \\
$x s s_{j m}$ & month $m$ associated with system $h(\mathrm{t})$ \\
$x t_{i j h m}$ & Quantity of logging residue stored at location $i$ in month $m$ associated \\
$x t l_{i j h s}$ & with system $h(\mathrm{t})$ \\
& Quantity of logging residue removed from storage at location $i$ in \\
& month $m$ associated with system $h(\mathrm{t})$ \\
& Quantity of woody biomass stored at plant $j$ in month $m(\mathrm{t})$ \\
& Quantity of logging residue delivered from supply location $i$ to plant $j$ \\
& in month $m$ associated with system $h(\mathrm{t})$ \\
& The increment of logging residue annually shipped out of supply \\
& location $i$ in the range $\left(a_{s-1}, a_{s}\right)(\mathrm{t})$
\end{tabular}


CHAPTER 4: ECONOMIC ASSESSMENT OF COAL AND BIOMASS TO LIQUID

FUELS IN CENTRAL APPLACHIA, USA*

\footnotetext{
${ }^{*}$ To be submitted to Biomass and Bioenergy.
} 


\begin{abstract}
Liquid fuels from coal and biomass have the potential to reduce petroleum fuel use and $\mathrm{CO}_{2}$ emission in the U.S. transportation sector. A multi-equation model was developed to assess the economics of a coal/biomass-to-liquids (CBTL) fuel plant in the central Appalachian region. Specifically, the objective was to minimize the total annual cost subject to a series of regional supply, demand, and other constraints. The model was developed and solved using General Algebraic Modeling System/Cplex solver. Model inputs include coal and biomass availability, biomass handling system type, plant investment, production capacity, transportation logistics, and project financing; while outputs include the optimal logistical decision-making together with feedstock requirement, collection, delivery, and liquid fuel production. The results indicated that the required selling price (RSP) of Fischer-Tropsch (FT) diesel for a 40,000 barrel-per-day CBTL plant with coal/biomass ratio of $85 / 15$ varied between $\$ 79.30 \mathrm{bbl}^{-1}$ and $\$ 79.57 \mathrm{bbl}^{-1}$ using the different biomass handling systems. The RSP of FT diesel heavily depended upon plant capacity, capital cost, coal price, and liquid fuel yield. The crude-oil-equivalent price of FT fuels must be above $\$ 62 \mathrm{bbl}^{-1}$ for a CBTL plant to be profitable in central Appalachia for the long run. These results can help investors/decision-makers evaluate future CBTL developments in the region.
\end{abstract}

\title{
4.1 Introduction
}

Concerns about tightening global supplies of oil, energy security, and climate change have caused a renewed interest in alternative sources of energy. The production of liquid fuels from coal provides an option of reducing the petroleum fuel use in the U.S. transportation sector and enhancing national and economic security by decreasing the nation's reliance on foreign oil (National Academy of Sciences 2009, Paul 2009). The technologies of coal-to-liquids (CTL) are 
well established and have existed for more than 80 years (Bibber et al. 2007). Two basic approaches can be used to produce liquid fuels from coal: direct coal liquefaction (DCL) and indirect coal liquefaction (ICL). Today, the world's major CTL production is located in South Africa, based on locally available low cost coal. Coal liquefaction is also given high priority in China. The largest coal producer, Shenhua Group, has launched a DCL plant with a capacity of 24,000 barrels per day. The obvious drawback of CTL technologies is the high carbon footprint of the process (Gray et al. 2007, Bartis et al. 2008). The life-cycle greenhouse-gas (GHG) emissions are about twice those of petroleum-based fuels (Bartis et al. 2008). The ability to capture and store carbon dioxide released is very important to producing liquid fuels from coal. If carbon capture and storage technologies were employed, a reduction of 5-12\% lifecycle GHG emissions could be achieved compared to the average emissions profile of petroleum-derived diesel (Tarka et al. 2009).

Biomass is the only carbon-bearing renewable energy resource, which makes it especially valuable for making carbon-bearing liquid transportation fuels. The introduction of biomass in a CTL process could further reduce GHG emissions (National Academy of Sciences 2009, Paul 2009, Gray et al. 2007, Tarka et al. 2009). The carbon contained in the biomass is not counted as a carbon input penalty because the biomass has removed this carbon from the atmosphere by photosynthesis (Gray et al. 2007). A recent study from the U.S. Department of Energy (DOE) National Energy Technology Laboratory (NETL) reported that a mixture of $8 \%$ biomass and $92 \%$ coal (by weight) can produce fuels which have $20 \%$ lower life cycle GHG emissions than petroleum-derived diesel fuel (Tarka et al. 2009).

Located in the central Appalachian region, the state of West Virginia (WV) is advancing CTL projects as an alternative to imported petroleum. As the nation's second largest coal- 
producing state, WV produced approximately 140 million metric tons of coal in 2007, about $13 \%$ of the U.S. total (West Virginia Coal Association 2007). It is also the third most heavily forested state and the harvesting process annually yields approximately 2.19 million dry metric tons of woody biomass which can be utilized as feedstock for liquid fuels (Wang et al. 2006). Other potential biomass feedstocks include agricultural residue and switchgrass. The abundant coal and biomass resources in WV provide a great opportunity for the production of liquid fuels using coal/biomass-to-liquid (CBTL) technologies. To date, there are no commercial CBTL facilities in WV. Industries that are interested in CBTL have very limited information about the availability of biomass and the impacts of factors such as biomass availability and feedstock cost on the production cost of liquid fuels. Work must be done to design a biomass harvesting and collection routine that enables such significant volume of biomass efficiently and economically to reach the CBTL plant gate on a daily basis.

The objective of this study was to develop a multi-equation economic model which incorporates several alternative biomass handling systems to assess the annual production cost of liquid fuels from coal and biomass in central Appalachia. Comparisons were made in terms of the required selling price (RSP) of liquid fuels among the systems in order to select the most suitable biomass handling system for the study region. The optimal logistical decision-makings linked to feedstock requirement, collection, delivery, and production were derived from the model results, which offered an opportunity to control the feedstock flow for the CBTL plant. Sensitivity analyses were carried out to examine the uncertainties of feedstock availability and cost, plant capacity, capital cost, and liquid fuel yield on the RSP. Some other issues relevant to the economics of the CBTL facility such as crude oil prices, government policies, etc. were also discussed. 


\subsection{Methodology}

\subsubsection{Description of the study area and feedstock availability}

The study area was the central Appalachian region of the U.S. A 40,000 barrel-per-day (BPD) CBTL plant was assumed to be located at Boone County, WV, where abundant coal resources have been found. The coal required for the plant was sourced from WV. Woody biomass was obtained from WV and the adjacent states including Kentucky (KY), Ohio (OH), Virginia (VA), Maryland (MD), and Pennsylvania (PA). Woody biomass inventory in central Appalachia was approximately 16.23 million dry metric tons (2005-2006 data) (USDA Forest Service 2009) (Table 4.1). The geographic distribution of coal and woody biomass in WV by county was illustrated in Figure 4.1. Cities near the center of the coal/biomass supply counties were used to represent the average locations of the counties. Subject to operational accessibility, harvesting techniques, and economic and environmental constraints, the recovery rate of logging residue was assumed to be $65 \%$. Only $40 \%$ of mill residue was assumed to be available for liquid fuels production due to the fact that mill residue at primary and secondary wood processing mills has been utilized as feedstock for agricultural/horticultural products, fiber and composites products, industrial fuel, and others. Therefore, the total woody biomass available could be up to 8.79 million metric tons per year. 
Table 4.1. Woody biomass in the central Appalachian region ${ }^{\mathrm{a}}$.

\begin{tabular}{lccc}
\hline States & $\begin{array}{c}\text { Logging residue } \\
\text { inventory }\left(\mathrm{t} \mathrm{yr}^{-1}\right)\end{array}$ & $\begin{array}{c}\text { Mill residue inventory } \\
\left(\mathrm{t} \mathrm{yr}^{-1}\right)\end{array}$ & $\begin{array}{c}\text { Total woody biomass } \\
\left(\mathrm{t} \mathrm{yr}^{-1}\right)\end{array}$ \\
\hline West Virginia & $1,143,979$ & 997,862 & $2,141,841$ \\
Kentucky & $1,877,458$ & $1,409,522$ & $3,286,980$ \\
Maryland & 365,576 & 202,279 & 567,855 \\
Ohio & 769,603 & 320,802 & $1,090,405$ \\
Pennsylvania & $2,320,933$ & $1,480,124$ & $3,801,057$ \\
Virginia & $2,711,508$ & $2,634,514$ & $5,346,022$ \\
Total & $9,189,057$ & $7,045,103$ & $16,234,160$ \\
\hline
\end{tabular}

${ }^{a}$ Data source: USDA Forest Service 2009. Moisture content: 43\%.

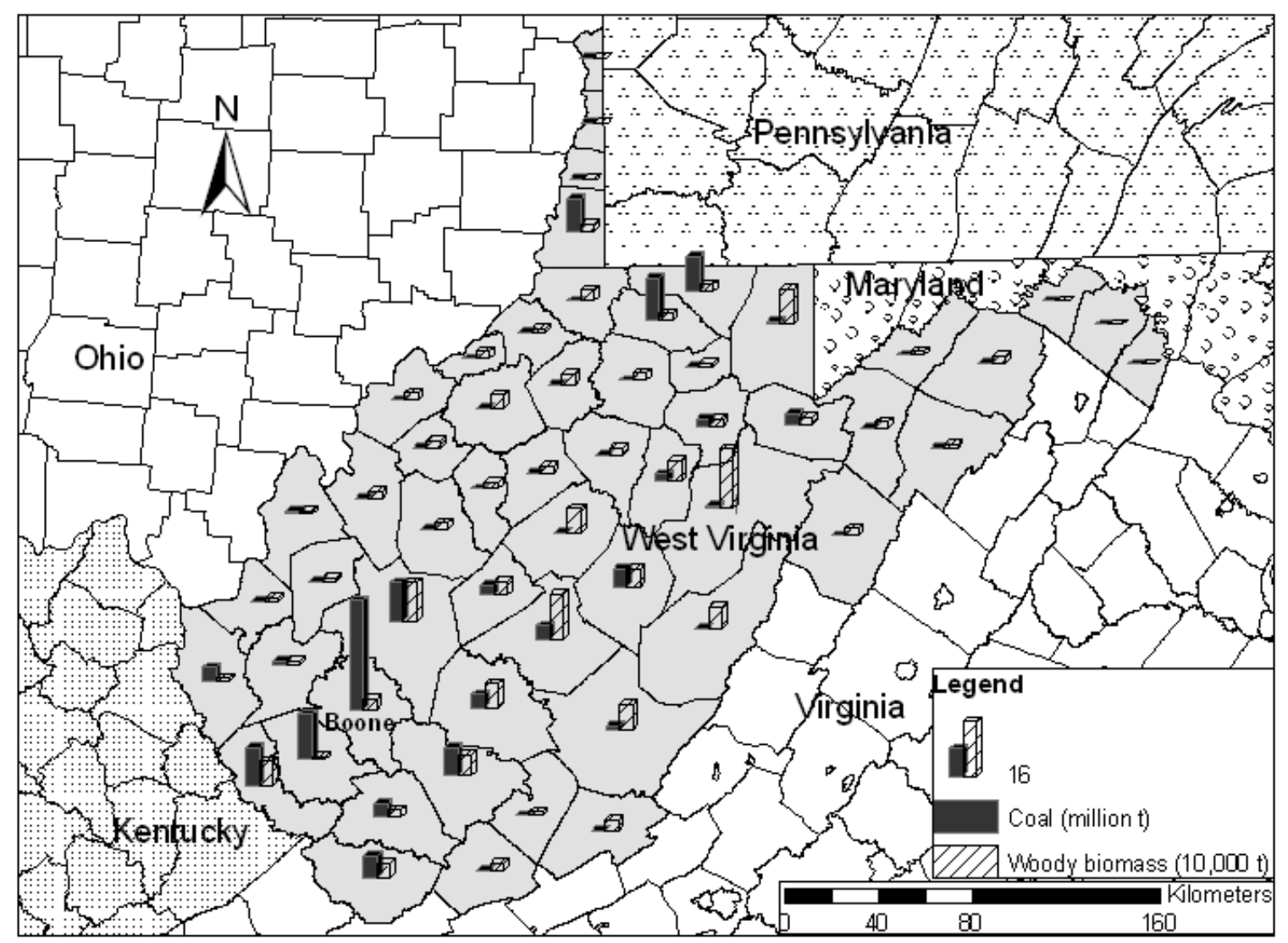

Figure 4.1. The scope of the study area. The bars symbolize the annual coal and woody biomass production in West Virginia. 
Switchgrass is another potential biomass feedstock for the CBTL plant. However, there is no switchgrass produced in WV or other states. The potential production was predicted by replacing some existing hay lands and reclaimed/un-reclaimed mines in WV with switchgrass. It was assumed that $10 \%$ of hay lands in WV, approximately 24,282 ha, could be used to produce switchgrass (USDA National Agricultural and Statistics Service 2008), which can result in 339,943 metric tons (Figure 4.2a). Ten percent of reclaimed and un-reclaimed coal mines in WV were assumed to be able to produce switchgrass with a potential yield of $6.74 \mathrm{tha}^{-1}$ (Figure $4.2 \mathrm{~b}$ ). Therefore, the total switchgrass production on hay lands and reclaimed mine areas in WV could be up to 0.48 million metric tons.

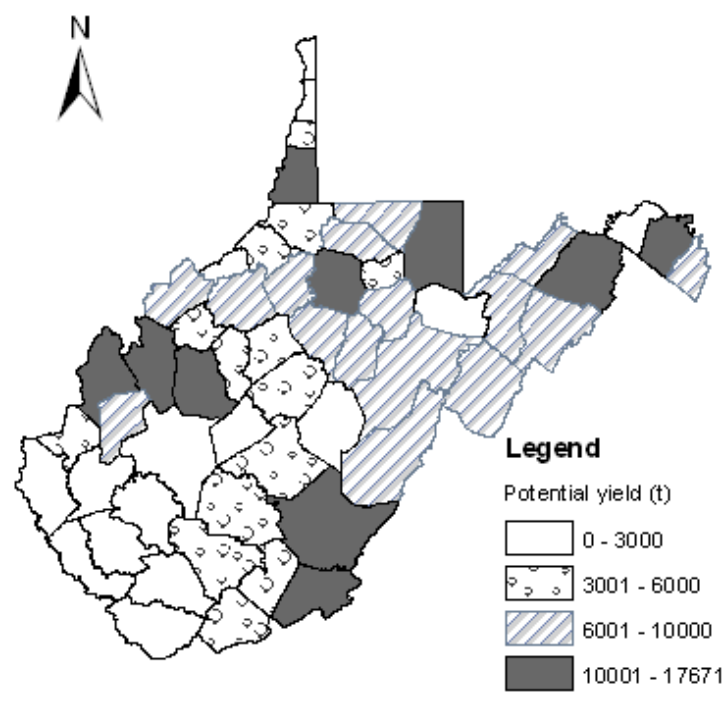

(a)

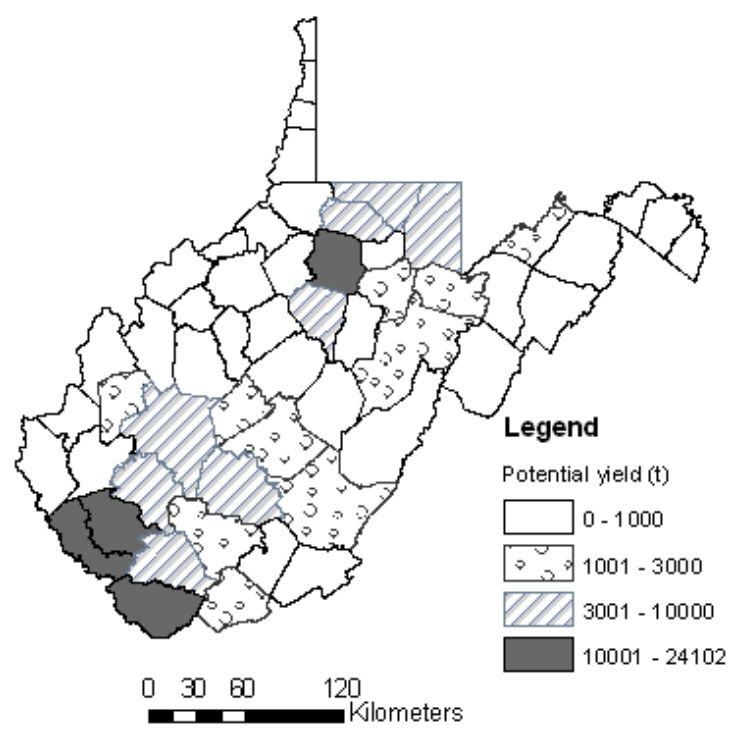

(b)

Figure 4.2. Predicted annual switchgrass production on (a) hay lands and (b) reclaimed mine fields in West Virginia assuming 10\% of lands used.

\subsubsection{Economic model description}

The structure of the model was shown in Appendix 4.A. All the parameters and variables in the model are described in Appendix 4.B. The General Algebraic Modeling System (GAMS) 
programming language was used and the model was solved using Cplex solver (Brooke et al. 1998).

A mixed-integer programming model has been developed by Wu et al. (2008) to estimate the delivered cost of woody biomass from forest to a plant. In this study, this model was expanded to incorporate annual plant investment, operating and maintenance costs, and coal and biomass (woody biomass and switchgrass) delivered cost. Four alternative biomass handling systems which include a series of process activities (i.e., extraction, storage, loading and hauling, and chipping/grinding) from forest to the CBTL plant were considered. Based on the extraction equipment used and the forms of biomass delivered, these systems were abbreviated as cable skidder-loose residue system (S1), cable skidder-chips system (S2), grapple skidder-loose residue system (S3), and grapple skidder-chips system (S4).

Hourly machine cost for each woody biomass handling activity was calculated using the machine rate method (Miyata 1980). The corresponding productivity was estimated based on the existing models developed for the study region (Li et al. 2006, Wang 2007). Therefore, the unit costs for extraction, loading, and chipping/grinding can be derived by dividing machine cost by the corresponding productivity. The costs associated with switchgrass handling activities include establishment, growth, harvest, storage, and transportation. The costs associated with coal include mining cost and transportation cost. Transportation cost was computed based on the delivery distance and the quantity delivered. Logging residue storage cost in the field was assumed to be zero. The storage cost of switchgrass was $\$ 2.00$ per metric ton (wet basis).

The new model has some special features that make it different from previous studies. First, various biomass handling systems were considered in the model, which allowed comparisons of the RSP and assisted to choose the most suitable biomass handling system for the 
study region. Factors affecting the quantity of biomass delivered to the plant such as productivity, local infrastructure capability, and seasonal harvesting rate were also considered in the model. Second, most studies assumed the prices paid for "as-received" feedstocks as constant, while in this model the feedstock cost varied depending on the availability of feedstock and the delivery distance from the supply sources to the plant. Meanwhile, the modeling results linked to feedstock requirement, collection, delivery, and production offers an opportunity to monitor the feedstock flow for the CBTL plant. Third, the annual investment cost was computed in consideration of commodity inflation, construction period, production period, and interest rate (using weighted average cost of capital in this paper). The financing structure (i.e., equity/debt), which is directly related to the weighted average cost of capital for the CBTL plant, was allowed to change to get in-depth insight on the RSP of FT diesel.

\subsubsection{Model assumptions}

\section{Plant assumptions}

The assumptions associated with the CBTL plant were summarized in Table 4.2. All the liquid fuels were converted to FT diesel-equivalent fuels assuming that the other product, naphtha, could be sold at $75 \%$ of diesel price on a per barrel basis (Gray et al. 2007). The four biomass handling systems (S1-S4) were employed in the model separately. The mix ratio of coal and biomass was assumed to be $85 / 15$ (by weight) for all biomass handling systems. Given the financing assumptions, the weighted average cost of capital was $8.93 \%$ per year and the levelized amortization factor was $16.55 \%$. 
Table 4.2. Summary of plant-related assumptions.

\begin{tabular}{|c|c|}
\hline Parameters & Assumptions in the base case \\
\hline Plant location & Boone County, WV \\
\hline Plant capacity (barrel day ${ }^{-1}$ ) & 40,000 \\
\hline Total investment cost (US\$ billion) & $2.87^{\mathrm{a}}$ \\
\hline Operation and maintenance cost (US\$ million $\mathrm{yr}^{-1}$ ) & $204^{\mathrm{a}}$ \\
\hline Conversion method & Indirect liquefaction \\
\hline Primary liquid fuel products & Diesel, naphtha, power \\
\hline Proportion of liquid fuels produced as a percentage & Diesel: $68.18 \%{ }^{\mathrm{a}}$ \\
\hline of the total liquid fuels & Naphtha: $31.82 \%{ }^{\mathrm{a}}$ \\
\hline Liquid fuels yield (barrel $t^{-1}$ ) & Coal: $2.475^{\mathrm{b}}$ \\
\hline Coal/biomass ratio (by weight) & $\underset{85 / 15}{\text { Biomass: } 1.452^{\mathrm{c}}}$ \\
\hline Construction period (yr) & 3 \\
\hline Plant life (yr) & 30 \\
\hline Plant maintenance factor & 1.04 \\
\hline Commodity inflation rate $(\%)$ & 2 \\
\hline Equity proportion (\%) & 40 \\
\hline Cost of Equity (\%) & 15 \\
\hline Cost of debt (\%) & 8 \\
\hline Federal tax $(\%)$ & 39 \\
\hline Minimum inventory at the plant (days) & 7 \\
\hline Maximum inventory at the plant (days) & 45 \\
\hline Operating time (days $\mathrm{yr}^{-1}$ ) & 350 \\
\hline
\end{tabular}

${ }^{a}$ Adapted and updated from Gray et al. 2007. The costs of biomass and coal are not included in the operating and maintenance cost. All the costs are in 2007 US\$;

${ }^{\mathrm{b}}$ Adapted from Bellman 2007;

${ }^{\mathrm{c}}$ Adapted from Williams 2007.

\section{Feedstock requirement}

Total feedstock (coal and biomass) required for a CBTL facility is dependent on the plant scale and the mix ratio of coal and biomass. The 40,000 BPD CBTL plant will require approximately 0.9 million dry metric tons of biomass and 5.1 million metric tons of coal per year. Figure 4.3 illustrated the annual feedstock needed corresponding to different plant scales 
and coal/biomass ratios. Considering the availability of the feedstock in the study region, it was sufficient to support the CBTL facility even if the plant capacity expanded to 80,000 barrels per day.

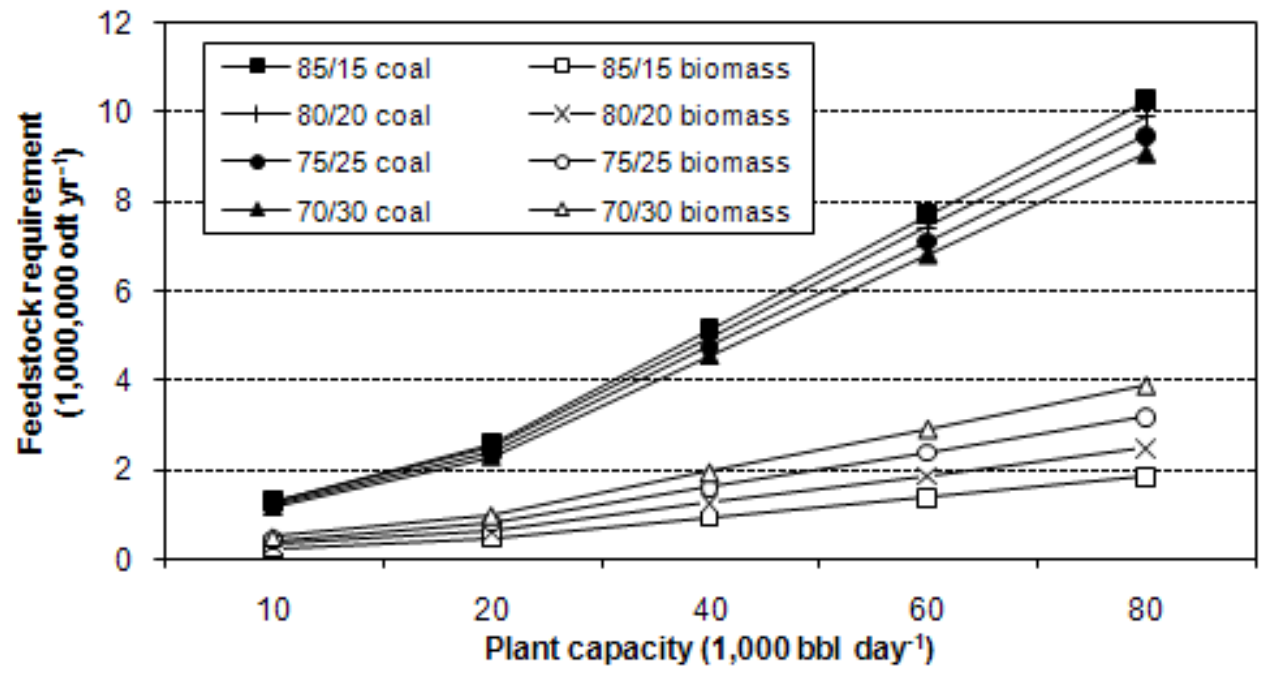

Figure 4.3. Annual feedstock requirement curve for each coal/biomass ratio.

\section{Feedstock characterization and handling costs}

The characterization of biomass in the study region was presented in Table 4.3. The assumptions of hourly machine cost, machine productivity, and unit production cost during biomass handling process were presented in Table 4.4. A stumpage cost $\$ 1 \mathrm{t}^{-1}$ (wet basis) was assumed for logging residue. The availability of logging residue by month was assumed to be (1$12,8.3 \%, 8.3 \%, 8.3 \%, 8.3 \%, 7.5 \%, 7.5 \%, 7.5 \%, 7.5 \%, 9.2 \%, 9.2 \%, 9.2 \%, 9.2 \%)$ in consideration of the historical harvesting activities that occurred and the impact of monthly precipitation on the accessibility to forest lands in the region (USDS 2009). The potential yield of switchgrass by harvest month was assumed to be $(1-12,0,0,0,0,0,0,100 \%, 100 \%, 100 \%, 95 \%, 90 \%, 85 \%)$ (Mapemba 2005). Transportation cost rate was assumed to be $\$ 0.18 \mathrm{t}^{-1} \mathrm{~km}^{-1}$ for loose logging residue, $\$ 0.12 \mathrm{t}^{-1} \mathrm{~km}^{-1}$ for wood chips, and $\$ 0.14 \mathrm{t}^{-1} \mathrm{~km}^{-1}$ for switchgrass bales, respectively. 
Table 4.3. Biomass characterization.

\begin{tabular}{|c|c|c|c|c|}
\hline & & ging residue & Mill residue & Switchgrass \\
\hline Stumpage/purchase & $\operatorname{rice}\left(\$ t^{-1}\right)^{a}$ & 1.00 & 22.00 & 50 \\
\hline Moisture content ( & & 43 & 43 & 15 \\
\hline Availability (\%) & & 65 & 40 & $10^{\mathrm{b}}$ \\
\hline Usable proportion & the field $(\%)^{c}$ & 95 & 95 & 95 \\
\hline Usable proportion & the plant $(\%)^{\mathrm{c}}$ & 99 & 99 & 99 \\
\hline Onsite storage cost & $\left.t^{-1}\right)$ & 0 & 0 & $2.00^{\mathrm{c}}$ \\
\hline $\begin{array}{l}\text { a Given as wet weight; } \\
\text { b Percentage of hay lar } \\
\text { c Adapted from Mapen }\end{array}$ & $\begin{array}{l}\text { and reclaimed coal } \mathrm{m} \\
\text { a } 2005 \text {, given as wet }\end{array}$ & $\begin{array}{l}\text { es available fo } \\
\text { ght. }\end{array}$ & vitchgrass proc & luction. \\
\hline Table 4.4. Summar & of cost assumption & by woody bi & mass handlin & g machines. \\
\hline & Hourly cost $\left(\$ \mathrm{~h}^{-1}\right)$ & Productivity & $\left(\mathrm{t} \mathrm{h}^{-1}\right)^{\mathrm{a}}$ & $\operatorname{Cost}\left(\$ t^{-1}\right)^{a}$ \\
\hline Cable skidder & 81.34 & 6.34 & & 12.83 \\
\hline Grapple skidder & 102.72 & 11.46 & & 8.96 \\
\hline Loader & 85.96 & 16.02 & & 5.36 \\
\hline Chipper & 185.62 & $30^{\mathrm{b}}$ & & 6.19 \\
\hline Grinder & 212.27 & $91^{\mathrm{b}}$ & & 2.33 \\
\hline
\end{tabular}

$\overline{{ }^{a}}$ Given as wet weight

${ }^{\mathrm{b}}$ Adapted from Kärhä and Vartiamäki 2006.

The coal-fired power plants were assumed to be the primary coal consumers due primarily to the fact that approximately $99 \%$ of electricity in WV is generated by coal produced in the state. The value for steam coal from U.S. Department of Energy's Annual Energy Outlook 2009 (USDOE 2009) was used to estimate the mine-mouth coal price (not including transportation cost). Adjusted for the base year of 2007, the value applied was $\$ 1.84 \mathrm{MMBTU}^{-1}$ 
or $\$ 50.60 \mathrm{t}^{-1}$ for central Appalachian coal. The transportation rate of coal was assumed to be $\$ 0.10 \mathrm{t}^{-1} \mathrm{~km}^{-1}$. Thus, hauling one metric ton of coal $50 \mathrm{~km}$ (one way) would cost $\$ 10.00$.

\subsection{Results}

\subsubsection{Required selling price of FT diesel}

With the assumptions above the highest RSP of FT diesel $\left(\$ 79.57 \mathrm{bbl}^{-1}, \$ 13.82 \mathrm{GJ}^{-1}\right)$ occurred with the cable skidder-chips system (S2), followed by the cable skidder-loose residue system $\left(\$ 79.55 \mathrm{bbl}^{-1}, \$ 13.81 \mathrm{GJ}^{-1}\right)(\mathrm{S} 1)$, the grapple skidder-loose residue system $\left(\$ 79.33 \mathrm{bbl}^{-1}\right.$, $\left.\$ 13.77 \mathrm{GJ}^{-1}\right)(\mathrm{S} 3)$, and the grapple skidder-chips system $\left(\$ 79.30 \mathrm{bbl}^{-1}, \$ 13.77 \mathrm{GJ}^{-1}\right)(\mathrm{S} 4)$. Since a lower RSP may lead to a higher profit, the grapple skidder-chips system would be the most suitable handling system for the CBTL plant. Table 4.5 presented the optimal biomass mix for the four biomass handling systems. Logging residue was the primary biomass feedstock delivered to the plant, followed by mill residue. The least quantity of switchgrass was delivered to the CBTL plant using the grapple skidder-chips system (S4). The following analysis will focus on the grapple skidder-chips system (S4). 
Table 4.5. Biomass delivered to the CBTL plant by system (40,000 bbl/day).

\begin{tabular}{lcccc}
\hline Systems & Logging residue $^{\mathrm{a}}$ & Mill residue $^{\mathrm{a}}$ & Switchgrass $^{\text {a }}$ & Total biomass $^{\mathrm{b}}$ \\
\hline S1 & 575,006 & 558,874 & 321,403 & 919,504 \\
S2 & 660,194 & 493,150 & 308,350 & 919,504 \\
S3 & 829,034 & 493,150 & 195,128 & 919,504 \\
S4 & $1,047,257$ & 319,085 & 165,517 & 919,504 \\
\hline
\end{tabular}

${ }^{\mathrm{a}}$ Given as t $\mathrm{yr}^{-1}$ (wet weight).

${ }^{\mathrm{b}}$ Given as $\mathrm{t} \mathrm{rr}^{-1}$ (dry weight).

The RSP of FT diesel on a barrel basis can be partitioned into capital cost, operating and maintenance (OM) cost, coal cost, and biomass cost (Figure 4.4). Comparisons in terms of RSP were made among five mixture ratios of coal/biomass including 100/0 (coal only), 85/15 (base case), $80 / 20,75 / 25$, and 70/30 using the most efficient system S4. The RSP increased gradually as more biomass was mixed with coal. The difference of RSP between the scenarios of coal only and coal/biomass ratio of $70 / 30$ was as much as $\$ 7.97 \mathrm{bbl}^{-1}$, increasing by almost $10.50 \%$. Since the use of biomass can reduce the life cycle greenhouse gas emissions (GHG), this increase can be treated as credit for greenhouse gas emissions offset. The cost of coal in a barrel of FT dieselequivalent liquid fuel decreased from $32 \%$ to $23 \%$ as the proportion of coal decreased from $100 \%$ to $70 \%$. Meanwhile, the cost of biomass increased from $0 \%$ to $12 \%$. Capital cost and operation and maintenance cost increased slightly as the percentage of biomass increase in that additional equipment will be needed for biomass handling at the CBTL plant. 


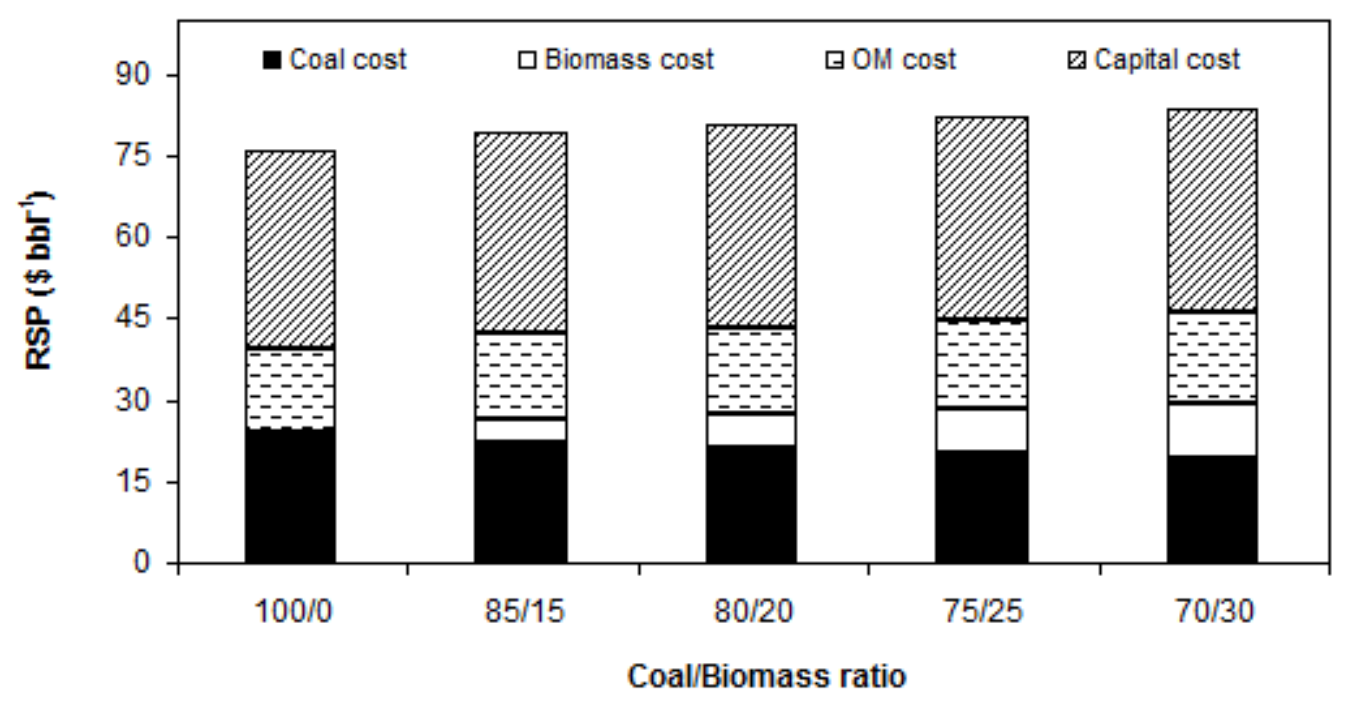

Figure 4.4. Cost components of one barrel of FT diesel-equivalent liquid fuel by coal/biomass ratio.

\subsubsection{Logistics optimization}

Figure 4.5 illustrated the optimal quantity of fuel delivered to the CBTL plant by month and by state using the grapple skidder-chips system. Approximately $66 \%$ of the logging residue delivered was from WV, followed by Kentucky (20\%), Virginia (9\%), and Ohio (5\%). The quantities of logging residue obtained from WV during May to August were lower than those in the other months, because the accessibility of logging residue was limited due to the higher average monthly precipitation during this period. For mill residue, 55\% were from WV, $20 \%$ from Ohio, $18 \%$ from Kentucky, and the rest were from Virginia. The delivery of mill residue was concentrated from January to June. The annual demand of approximately 5.10 million metric tons of coal could be met via Boone County, WV. The peak value of the quantity of coal delivered presented in January due to the requirement of inventory at the plant. Switchgrass was delivered to the plant from July to December because of the seasonal difference of growing yield. 


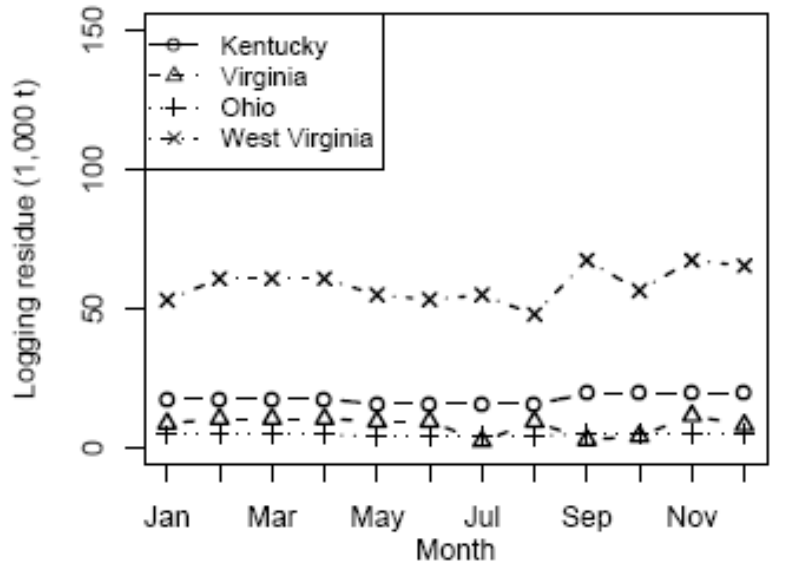

(a)

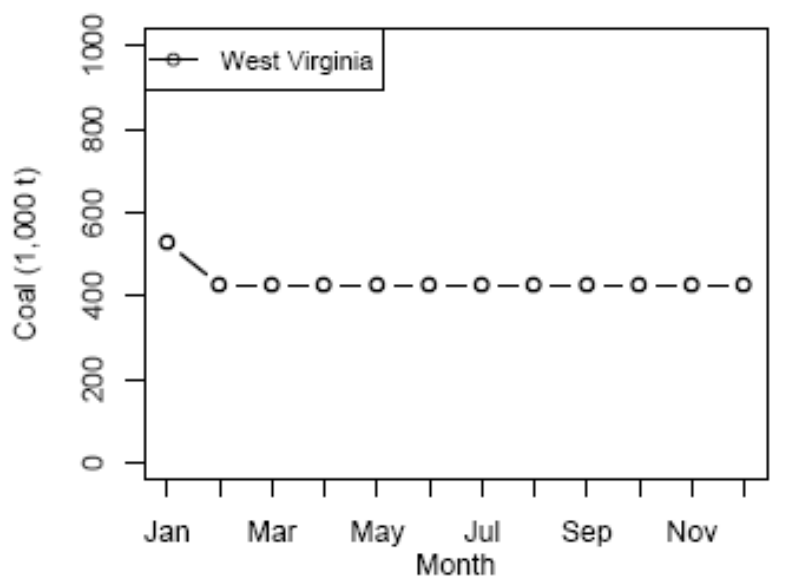

(c)

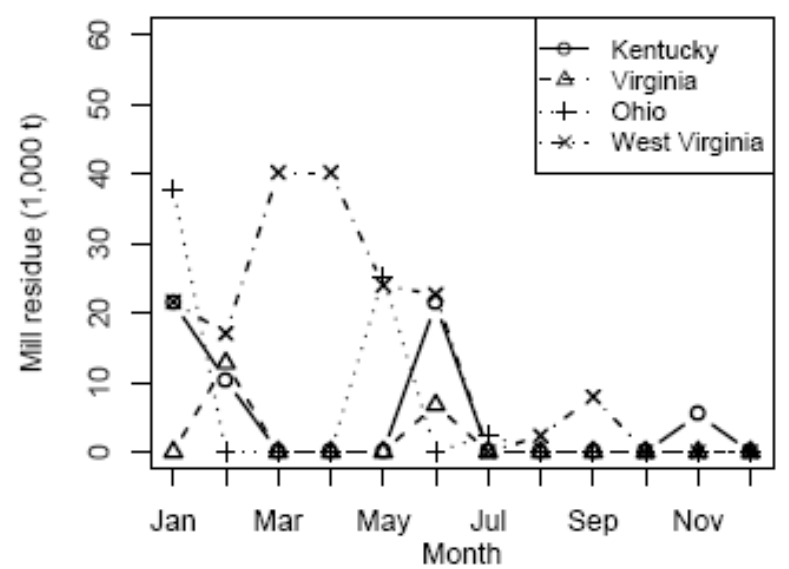

(b)

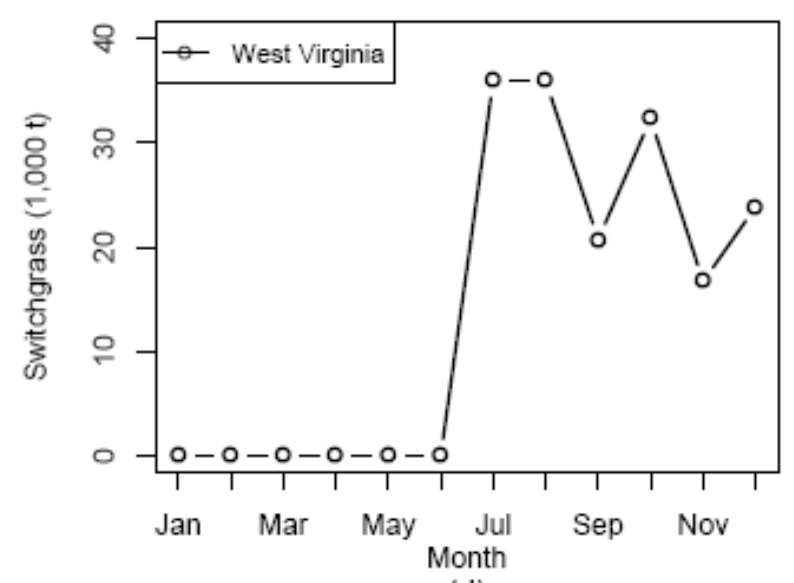

(d)

Figure 4.5. Feedstock delivered to the CBTL plant by month and by state.

\subsubsection{Sensitivity analyses}

\section{Biomass availability and cost}

Woody biomass was the primary biomass feedstock for the CBTL plant, accounting for approximately $70-85 \%$ of the total biomass (dry weight) delivered among the different coal/biomass ratios using the grapple skidder-chips system. Therefore, the variation of woody biomass availability is likely to have considerable impact on the RSP. Figure 4.6a displayed that the RSP of FT diesel decreased as the availability of woody biomass increased. If the availability of woody biomass decreased to $10 \%$, the RSP would increase $1.11-3.78 \%$ compared to the base case depending upon the percentage of biomass co-fed with coal. Increases in harvest efficiency 
are important to the future economic viability of forest residues, however, the implications must be weighted against potential impacts on site productivity, especially for low-productivity sites (Grushecky et al. 2007, Scott and Dean 2006). The availability of hay lands and reclaimed coal mines that could be switched to switchgrass production had minor impact on the average RSP (Figure 4.6b) due to the high production cost and the scattered distribution of the lands used for switchgrass production.

As more mill residue is utilized, the intense competition on this feedstock will force the purchase price to increase. Figure 4.6c illustrated that the RSP of FT diesel increased as the purchase price of mill residue at mill gates increased. If the purchase price decreased $55 \%$ to $\$ 10$ $\mathrm{t}^{-1}$, the RSP would decrease $0.94-1.36 \%$ compared to the base case. A $36 \%$ increase of mill residue purchase price (from $\$ 22 t^{-1}$ to $\$ 30 t^{-1}$ ) would cause the RSP to increase $0.18-0.46 \%$. Similar to the effects of increasing mill residue purchase price, increasing the production cost of switchgrass would increase the RSP especially with lower coal/biomass ratios (Figure 4.6d). If the production cost increased $30 \%$, the RSP would increase $0.03-0.35 \%$ compared to the base case among the different coal/biomass ratios. By contrast, a 30\% decrease of switchgrass production cost would cause a decrease of $0.49-1.11 \%$ in RSP. 


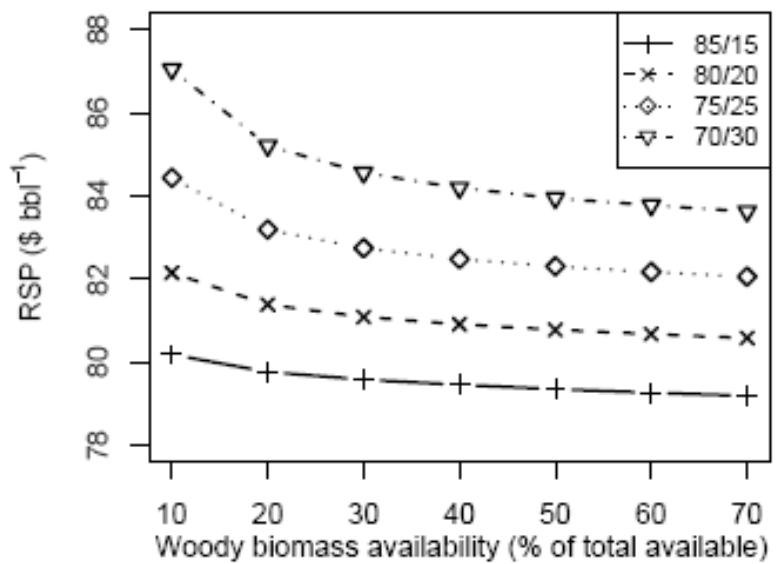

(a)

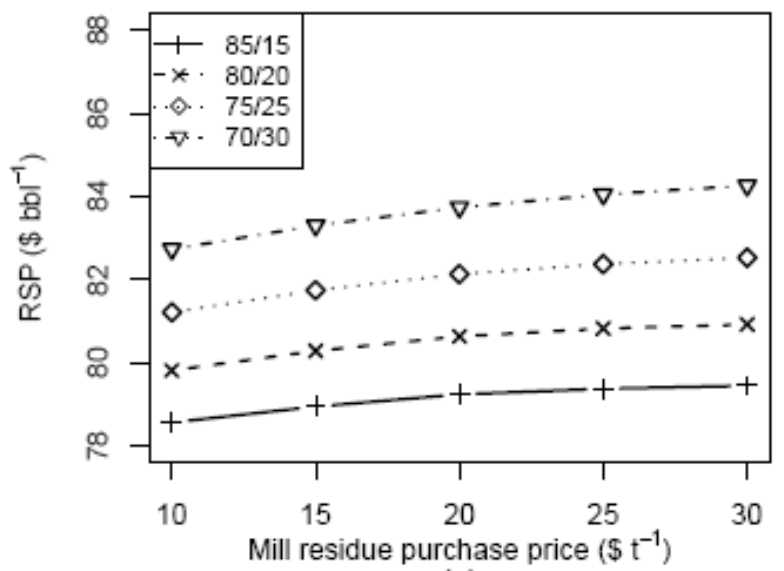

(c)

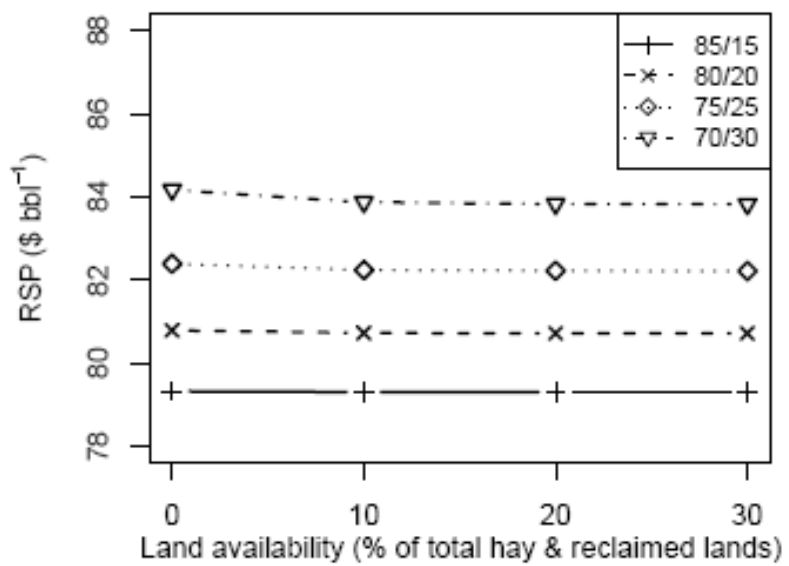

(b)

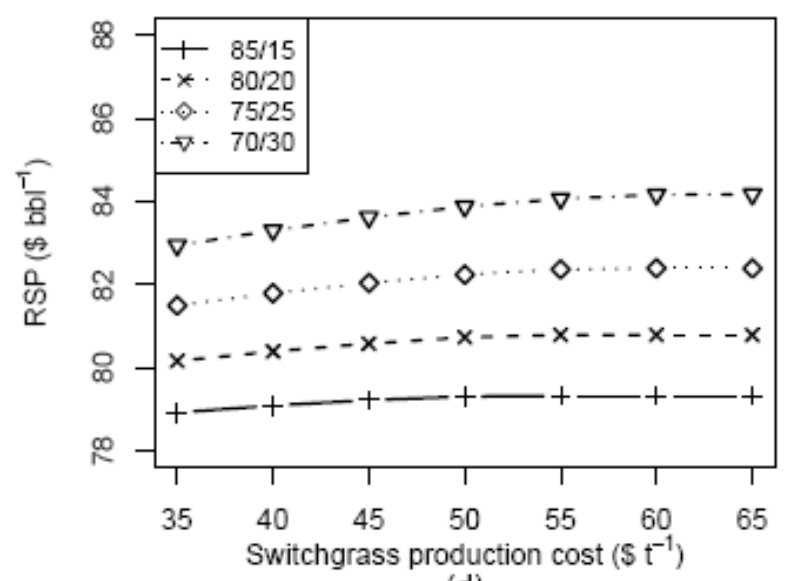

(d)

Figure 4.6. Effects of feedstock availability and costs on the RSP.

\section{$\underline{\text { Plant capacity }}$}

The plant capacity was found to have significant impact on the RSP of FT diesel among the four mix levels of coal and biomass (Figure 4.7a). The RSP for a large-scale CBTL plant was smaller due to the economy of scale. As the plant capacity increased, the average production cost of FT diesel associated with the plant investment decreased. Meanwhile, the economy of scale was partially offset by increased transport costs associated with hauling feedstock (coal and biomass) or more expensive nearby feedstock such as switchgrass. As shown earlier, the RSP was higher when the mix ratio of coal and biomass was lower. If the plant capacity was decreased from 40,000 barrels to 10,000 barrels per day, the RSP would be around $\$ 101.05$ - 
$104.86 \mathrm{bbl}^{-1}$, increasing by $25-27 \%$ among the different coal/biomass ratios. If the capacity approached 80,000 barrels per day, the RSP would decrease 8.3-9.7\% compared to the base case.

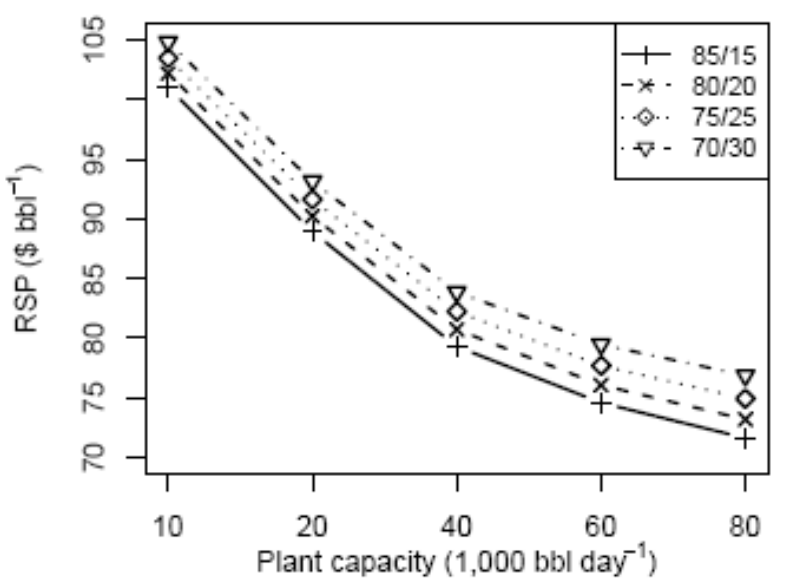

(a)

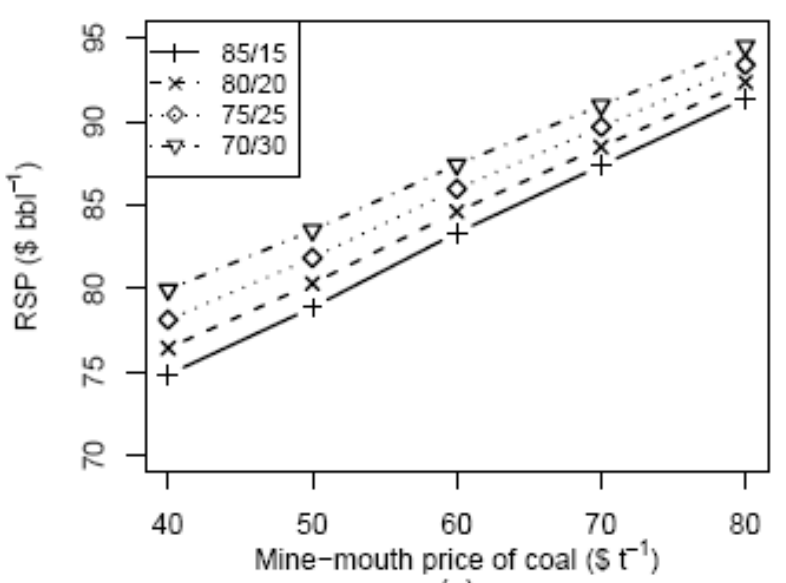

(c)

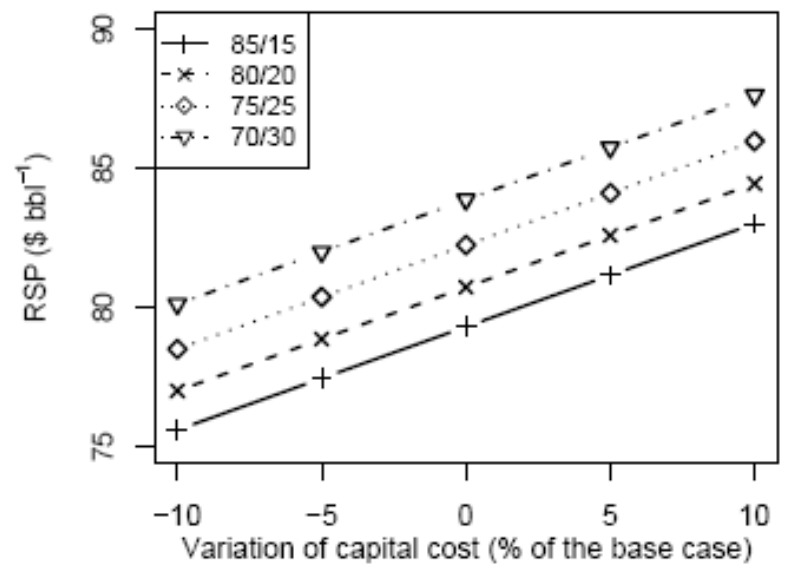

(b)

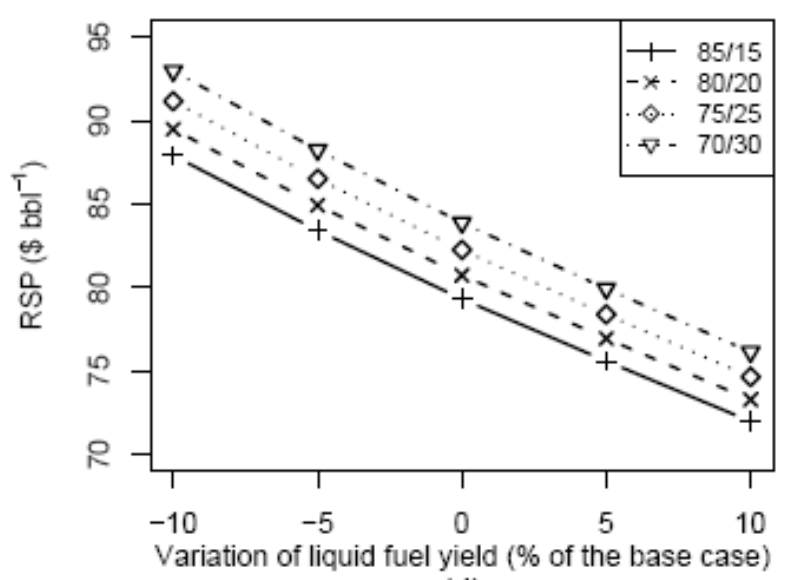

(d)

Figure 4.7. Effects of plant-related assumptions on the RSP.

\section{$\underline{\text { Capital cost }}$}

Limited data is available for the actual capital cost of a CBTL plant in the U.S., since no commercial CBTL plants have been built in the nation. In the base case, the capital cost was adapted from a NETL report (Gray et al. 2007). A typical scale factor 0.7 and Marshall \& Swift equipment cost index was applied to adjust the capital cost to the 40,000 BPD production level at the initial project year. The total plant cost was estimated as $\$_{2007} 2.87$ billion. The high estimates are due to the significant risks related to building a first-of-a-kind plant, including uncertainties 
about technical performance, capital and production costs, and environmental performance (Paul 2009). As multiple plants are built, this cost is likely to decrease through design advancements and process improvements. Figure $4.7 \mathrm{~b}$ illustrated the impact of the variation of capital cost on the RSP. It is important to note that a change in capital cost by $5 \%$ would change the RSP by $2.24-2.34 \%$, and a $10 \%$ change would result in a change of $4.48-4.68 \%$ in RSP.

\section{Mine-mouth price of coal}

The average mine-mouth price of Appalachian coal is generally higher than that in the Western and Interior regions in the U.S. The average spot prices of central Appalachian coal commodity have presented wide variation within the past two years with the peak value of $\$ 154$ $\mathrm{t}^{-1}$ during mid-2008 and the lowest value of $\$ 45 \mathrm{t}^{-1}$ in early 2007 (USDOE 2009). Since the delivered cost of coal accounted for approximately $23-32 \%$ of the RSP for one barrel FT liquid fuel, the variation of mine-mouth price of central Appalachia coal is likely to have considerable impact on the RSP. Figure 4.7c showed that the RSP increased linearly with the mine-mouth price of coal holding the other system assumptions constant. For every $\$ 10 \mathrm{t}^{-1}$ increase in coal price, the RSP would increase $\$ 4.14 \mathrm{bbl}^{-1}$ for the coal/biomass ratio of $85 / 15, \$ 3.98 \mathrm{bbl}^{-1}$ for the ratio of $80 / 20, \$ 3.82 \mathrm{bbl}^{-1}$ for the ratio of $75 / 25$, and $\$ 3.65 \mathrm{bbl}^{-1}$ for the ratio of $70 / 30$. If the mine-mouth price of coal increased to $80 \$ \mathrm{t}^{-1}$, the RSP would increase $13-15 \%$ among the different coal/biomass ratios compared to the base case.

\section{Liquid fuel yield}

The liquid fuel yield is also an important factor affecting the economics of CBTL plants. In the study, 2.475 barrels of liquid fuels from one metric ton of coal and 1.452 barrels of liquid 
fuels from one dry metric ton of biomass were assumed as the base case. The changes of the RSP were approximately proportional to the change of FT liquid fuel yield holding other parameters in the model constant (Figure 4.7d). If the liquid fuel yield increased by 5\%, the RSP would decrease $4.70 \%$ for all the mix levels of coal and biomass. An increase in liquid fuel yield by $10 \%$ changed the RSP by $9.24 \%$.

\subsubsection{Diesel replacement and greenhouse gas emissions}

The annual production capacity of the CBTL plant is 14 million barrels per year, which includes about 9.55 million barrels of FT diesel and 4.45 million barrels of Naphtha. Since the energy content of FT diesel is about $93 \%$ of diesel fuel, 8.93 million barrels of diesel fuel consumption could be replaced with FT diesel in the central Appalachian region.

The greenhouse gas emissions (GHG) from CBTL can be significantly lower than that of petroleum-derived diesel fuel (Tarka et al. 2009). The "Well-to-Wheels" (WTW) life cycle GHG emissions from petroleum-derived diesel are $95 \mathrm{~kg} \mathrm{CO}_{2}$ equivalent/MMBtu (Tarka et al. 2009). If $15 \%$ biomass (by weight) was mixed with coal, the GHG emissions could be $63.4 \mathrm{~kg} \mathrm{CO}_{2}$ equivalent/MMBtu, decreasing by 33\% compared to petroleum-derived diesel. For the base plant (40,000 BPD), approximate 3.31 million metric tons of $\mathrm{CO}_{2}$ equivalent $\mathrm{GHG}$ would be emitted per year. If the same amount of energy were produced from petroleum-derived diesel fuel, the GHG emissions would be 4.95 metric tons per year.

\subsection{Conclusions and discussion}

This study developed an economic model to estimate the total annual cost and RSP of liquid fuels from coal and biomass subject to regional supply, demand, and other constraints. The 
central Appalachian region in the U.S. was used as a case study. Results showed that the RSP of FT liquid fuels for a 40,000 BPD plant in the study region varied between $\$ 79.30 \mathrm{bbl}^{-1}(\$ 13.77$ $\left.\mathrm{GJ}^{-1}\right)$ and $\$ 79.57 \mathrm{bbl}^{-1}\left(\$ 13.82 \mathrm{GJ}^{-1}\right)$ among four biomass handling systems with coal/biomass ratio of $85 / 15$, or between $\$ 79.30 \mathrm{bbl}^{-1}\left(\$ 13.77 \mathrm{GJ}^{-1}\right)$ and $\$ 83.87 \mathrm{bbl}^{-1}\left(\$ 14.56 \mathrm{GJ}^{-1}\right)$ among the different coal/biomass ratios using the most efficient handling system (S4), which was significantly lower than the energy cost of cellulosic ethanol $\left(\$ 24.27-25.03 \mathrm{GJ}^{-1}\right)(\mathrm{Wu}$ et al. 2009). All the coal required for the plant was from Boone County, WV. Woody biomass was the major biomass feedstock for the plant, accounting for approximately $70-85 \%$ of the total biomass delivered among the different coal/biomass ratios. A limited amount of switchgrass was in demand especially when the coal/biomass ratio is higher.

The RSP of FT liquid fuels were shown to heavily depend upon plant capacity, capital cost, mine-mouth coal price, and liquid fuel yield. A large-scale plant required a lower RSP to recover the production cost by taking advantage of economies of scale. However, potential technical and financial risks are also higher along with a larger plant. An increase in plant scale will cause the demand of feedstock, especially coal, to increase accordingly. The competition for coal used for power generation and coal exports could potentially drive up the price of coal for the CBTL plant to the point of it not being economically viable. Reliable operation is also important to assure that the cost of project development and construction can be recovered (Bibber et al. 2007). Biomass availability and costs have showed moderate impacts on the RSP. Meanwhile, the security of biomass supply chain was an important factor to be considered. The CBTL system could include many key market players such as forest industries, mine industries, and farms or landowners. A cooperative program is necessary among these players to assure the raw materials supply for the CBTL commercial development. 
Other external factors that could affect the economics of the CBTL plant in the central Appalachian region include crude oil prices, project financing, and government policies. During the past four years, crude oil prices have changed between $\$ 30.28$ and $\$ 145.31$ per barrel in the U.S. (Figure 4.8). It is generally agreed that CTL/CBTL plants can be profitable at very low gas prices and relatively sustained high oil prices. If a factor of 1.3 was used to convert the RSP to crude oil equivalent (COE) price based on an average price ratio of low sulfur No.2 diesel to West Texas intermediate crude oil (Gray et al. 2007), the COE of FT fuels would vary between $\$ 61.00$ and $\$ 61.21$ per barrel among the four biomass handling systems. Notice that the cost for carbon dioxide transportation, sequestering, and monitoring (TS\&M) was not included. Gray et al. (2007) assumed that a cost of $\$ 4.60 \mathrm{t}^{-1}$ can be added for $\mathrm{CO}_{2}$ TS\&M, which increased the RSP of the FT fuels by about $1.8 \%$. Therefore, the COE price of FT fuels must be above $\$ 62 \mathrm{bbl}^{-1}$ for the CBTL plant (coal/biomass=85/15) with CCS to make long-term economic sense.

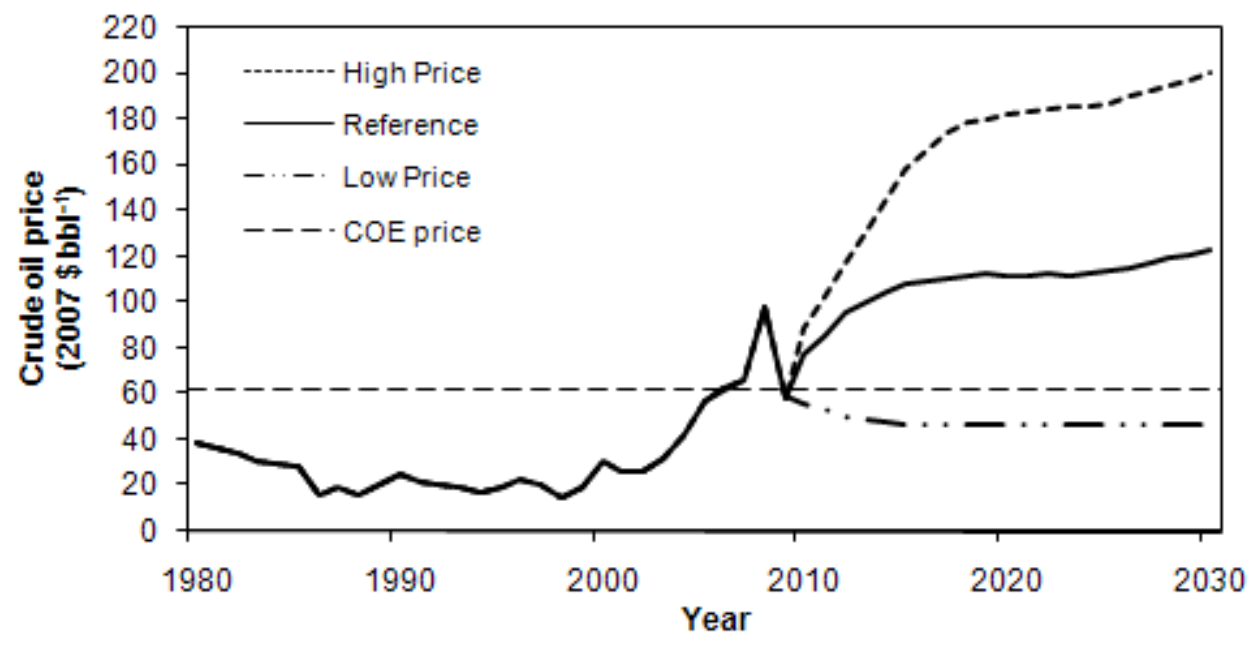

Figure 4.8. Crude oil price projections (USDOE 2009) and COE of FT diesel products.

Project financing is the biggest challenge to the CBTL plant. Even though the clean coal technology is proven, the high construction cost associated with building a commercial plant is still a major hurdle. Some technical risks that would be considered by process developers and 
industry partners could be reduced substantially as soon as several first-mover plants become operational. However, current low prices in the crude oil market, continued uncertainty on regulatory rules, and the financial crisis are making the financing of CBTL plants difficult. In this study, the project was financed with $40 \%$ equity and $60 \%$ debt. A $10 \%$ increase in owner's equity may increase the RSP by about $2.30 \%$ holding other financing assumptions constant.

Government support in terms of tax incentives, guarantee loans, and grants are important to maintain commercial viability for the CBTL plant. Due to the potential risk and high construction cost, current FT projects often involve a complex mix of industry partners and government subsidies. The relevant federal subsidy for liquid fuels from coal is the $\$ 21 \mathrm{bbl}^{-1}$ (50 cents gallon $^{-1}$ ) incentive included in the 2005 Federal Transportation Bill, which will end in 2009 (Bibber 2007). Loan guarantees and price floors can ensure that liquid fuels from CBTL process can compete with conventional petroleum-derived fuels even in the event that oil prices drop in the future.

Future research will be needed to enhance the insight in the environmental impacts of the CBTL plant and the sustainability of biomass supply in the central Appalachian region. The life cycle assessment of GHG emissions, potential risk to water quality, and land use competitions will be conducted. 


\section{References}

Brooke, A., Kendrick, D., Meeraus, A., and Raman, R. 1998. GAMS: a user's guide. GAMS Development Corporation.

Bellman, D. 2007. Coal to liquids. Working document of the NPC global oil and gas study

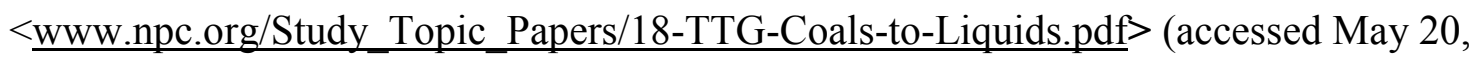
2009).

Bibber, L.V., Shuster, E., Haslbeck, J., Rutkowski, M., Olson, S., and Kramer, S. 2007. Baseline technical and economic assessment of a commercial scale Fischer-Tropsch liquids facility. US Department of Energy, National Energy Technology Laboratory [DOE/NETL-2007/1260].

Bartis, J., Camm, F., and Ortiz, D. 2008. Producing liquid fuels from coal: prospects and policy issues. RAND Corporation, p. 17.

Grushecky, S., Wang, J., and McGill, D. 2007. Influence of site characteristics and costs of extraction and trucking on logging residue utilization in southern West Virginia. Forest Products Journal 57(7/8):63-67.

Gray, D., White, C., Tomlinson, G., Ackiewicz, M., Schmetz, E., and Winslow, J. 2007. Increasing security and reducing carbon emission of the U.S. transportation sector: A transformational role for coal with biomass. US Department of Energy, National Energy Technology Laboratory [DOE/NETL-2007/1298].

Kärhä, K. and Vartiamäki, T. 2006. Productivity and costs of slash bundling in Nordic conditions. Biomass and Bioenergy 30:1043-1052.

Li, Y., Wang, J., Miller, G., and McNeel, J. 2006. Production economics of harvesting smalldiameter hardwood stands in central Appalachia. Forest Products Journal 56(3):81-86. 
Miyata, E.S. 1980. Determining fixed and operating costs of logging equipment. General Technical Report. NC-55. USDA Forest Service, St. Paul, Minnesota, USA.

Mapemba, L.D. 2005. Cost to deliver lignocellulosic biomass to a biorefinery. Ph.D. Dissertation. Oklahoma State University, Stillwater, OK, USA.

National Academy of Sciences, National Academy of Engineering, and National Research Council. 2009. Liquid transportation fuels from coal and biomass: technological status, costs, and environmental impacts. Washington, DC: National Academies Press.

Paul, A.D. 2009. A fresh look at coal-derived liquid fuels. Power Magazine. January 1, 2009. $<$ http://www.powermag.com/coal/A-Fresh-Look-at-Coal-Derived-LiquidFuels_1607.html> (accessed July 8, 2009).

Scott, D.A. and Dean, T.J. 2006. Energy trade-off between intensive biomass utilization, site productivity loss, and ameliorative treatments in loblolly pine plantation. Biomass and Bioenergy 30(12):1001-1010.

Tembo, G., Epplin, F., and Huhnke, R.R. 2003. Integrative investment appraisal of a lignocellulosic biomass-to-ethanol industry. Journal of Agricultural and Resource Economics 28(3):611-633.

Tarka, T.J., Wimer, J.G., Balash, P.C., Skone, T.J., Kern, K.C., Vargas, M.C., Morreale, B.D., White, C.W., and Gray, D. 2009. Affordable low-carbon diesel fuel from domestic coal and biomass. US Department of Energy, National Energy Technology Laboratory [DOE/NETL-2009/1349].

US Department of Agriculture, National Agricultural and Statistics Service. 2008. Quick statsWest Virginia data $<$ http://www.nass.usda.gov/> (accessed October 26, 2008). 
US Department of Agriculture, Forest Service. 2009. Timber products output map maker version

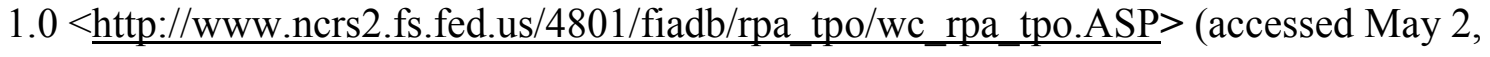
2009).

US Department of State. 2009. West Virginia weather. $<\underline{\text { http://countrystudies.us/united- }}$

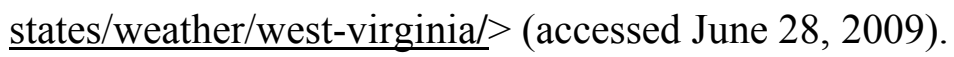

US Department of Energy, Energy Information Administration. 2009. Annual Energy outlook $2009<$ http://www.eia.doe.gov/oiaf/aeo> (accessed July 10, 2009).

Wang, J., Grushecky, S., and McNeel, J. 2006. Biomass resources, uses, and opportunities in West Virginia. West Virginia University, Biomaterials Center, Morgantown, USA.

Wang, J. 2007. Hardwood log bucking and loading efficiency in West Virginia. Forest Products Journal 57(5):1-7.

West Virginia Coal Association. 2007. West Virginia Coal Association releases 2007 coal facts $<$ http://www.wvcoal.com/news/news-archive/85-west-virginia-coal-association-releases2007-coal-facts.html> (accessed March 26, 2009).

Williams, R.B. 2007. Biofuels from municipal wastes-background discussion paper. California Biomass Collaborative $4^{\text {th }}$ Annual Forum, Advanced Bioenergy Technologies and Biofuels from Municipal Wastes $<$ biomass.ucdavis.edu/materials/reports\%20and\%20publications/2007/2007_Annual_For um_Background_Paper.pdf $>$ (accessed March 26, 2009).

Wu, J., Wang, J., and McNeel, J. 2008. Economic modeling of woody biomass utilization for biofuels: a case study in West Virginia. In: Baker SA, Bolding MC, Greene WD, editors. Proceedings of the 31st Annual Meeting of Council on Forest Engineering, Charleston, South Carolina, USA. p. 206-218. 
Wu, J., Sperow, M, and.Wang, J. 2009. Economic feasibility of a woody biomass-based ethanol plant in Central Appalachia, USA. Submitted to Journal of Agricultural and Resource Economics. 


\section{Appendix 4.A. Economic analysis model specification}

The model is designed to produce the required amount of liquid fuels from coal and biomass using the indirect coal liquefaction technology at a minimum cost subject to a series of regional supply, demand, and logistical constraints.

Objective:

Min $O B J=F+O M+\zeta \times T P C$

Where,

$$
\begin{aligned}
& \zeta=\psi \times\left[\frac{q^{N+p}-1}{(q-1) \times q^{N+p}}-\frac{q^{p}-1}{(q-1) \times q^{p}}\right]^{-1} \\
& q=(1+W A C C) \times(1+r) \\
& W A C C=w_{e} \times R_{e}+\left(1-w_{e}\right) \times R_{d} \times(1-f t)
\end{aligned}
$$

Subject to:

Eq. (A.5) describes the annual feedstock cost $F$, which is composed of the costs associated with all the handling activities of woody biomass, switchgrass, and coal from supply locations to the plant location.

$$
\begin{aligned}
F= & \sum_{i=1}^{I} \sum_{h=1}^{H} \sum_{m=1}^{12}\left[\left(H C_{h}+S P\right) \times x h_{i h m}+S C \times x p S_{i h m}\right]+\sum_{i=1}^{I} \sum_{j=1}^{J} \sum_{h=1}^{H} \sum_{m=1}^{12}\left(T C_{i j h}+L C_{h}+C S_{h}+C P_{h}\right) \times x t_{i j h m} \\
& +\sum_{i=1}^{I} \sum_{j=1}^{J} \sum_{m=1}^{12}\left(M C+M T \times D_{i j}\right) \times x m_{i j m}+\sum_{w=1}^{W} \sum_{m=1}^{12}\left(S W C \times x S w_{w m}+S W S \times x p w_{w m}\right) \\
& +\sum_{w=1}^{W} \sum_{j=1}^{J} \sum_{m=1}^{12}\left(S W T_{w j}+S C P\right) \times x t w_{w j m}+\sum_{w=1}^{W} \sum_{j=1}^{J} \sum_{m=1}^{12}(C T+P C) \times x C o_{w j m}+L C T_{1}+L C T_{2}
\end{aligned}
$$

Eq. (A.6) is used to compute the under-estimated transportation cost for woody biomass and switchgrass when the supply and demand locations are in the same county or adjacent counties (Wu et al. 2008). 


$$
\left\{\begin{array}{l}
L C T_{1}=\sum_{i=1}^{I} \sum_{j=1}^{J} \sum_{h=1}^{H} \sum_{s=1}^{S} T_{h} \times F C_{s} \times x t l_{i j h s}, \text { where } D_{i j} \leq R S_{i}, 0 \leq x t l_{i j h s} \leq a_{s}-a_{s-1} \\
L C T_{2}=\sum_{w=1}^{W} \sum_{j=1}^{J} \sum_{s=1}^{S} T S W \times F C_{s}^{\prime} \times x t w l_{w j s}, \text { where } D_{w j} \leq R S_{w}, 0 \leq x t w l_{w j s} \leq b_{s}-b_{s-1} \\
\sum_{s=1}^{S} x t l_{i j h s}=\sum_{m=1}^{12} x t_{i j h m}, \forall i, j, h . \\
\sum_{s=1}^{S} x t w l_{w j s}=\sum_{m=1}^{12} x t w_{w j m}, \forall w, j .
\end{array}\right.
$$

Eq. (A.7) describes the number of CBTL plants being built in the study region.

$$
\sum_{j=1}^{J} \beta_{j}=1
$$

Eq. (A.8) defines the number of biomass handling systems used in the study region. The model will evaluate each handling system separately, depending on the value Eq. (A.8) is set to. As stated by Eq. (A.8), the cable skidder-loose residue system will be applied in all the biomass supply locations.

$$
\left\{\begin{array}{l}
\sum_{h=1}^{H} A L F A_{i h}=1, \forall i, h=1, \cdots, 4 . \\
A L F A_{i h}=1, \quad \forall i, \text { where } h=1 .
\end{array}\right.
$$

Eqs. (A.9) - (A.12) are the constraints for the availability of logging residue and mill residue. The amount of logging residue extracted is subject to the available logging residue left in the study region in Eq. (A.9).

$\sum_{m=1}^{12} x h_{i h m}-A L F A_{i h} \times B P_{i} \times B I V_{i} \leq 0, \forall i, h$

The availability of logging residue during a certain time period (e.g. a month) is also considered in Eq. (A.10). Seasonal difference of wood harvesting caused by weather condition 
and other factors is contributable to the variation of the proportion of logging residue available during a certain time period.

$\sum_{h=1}^{H} x h_{i h m}-E X T_{m} \times B P_{i} \times B I V_{i} \leq 0, \forall i, m$.

Eq. (A.11) is the constraint for local loggers' capability of extracting logging residue, which is affected by the number of loggers in the study region, the number of machines owned, and the productivity of extraction machines.

$x h_{i h m}-\lambda \times P D_{h} \times N L_{i} \times N M_{h} \leq 0, \forall i, h, m$.

Eq. (A.12) requires that the quantity of mill residue shipped out of a supply county is limited by the available mill residue at that location.

$\sum_{j=1}^{J} \sum_{m=1}^{12} x m_{i j m}-M P_{i} \times M I V_{i} \leq 0, \forall i$.

Eqs. (A.13) - (A.15) are the constraints for the storage balance of logging residue at landings. The logging residue shipped to plant locations together with the amount stored at landings should not exceed the total logging residue extracted and the usable storage for any supply location at any time in Eq. (A.13). The biomass shipped out plus the biomass lost in-field should be balanced with the total biomass extracted in the year in Eq. (A.14). Eq. (A.15) describes the interrelationship among logging residue extracted, entered into storage, removed from storage, and transported to plant locations (Wu et al. 2008).

$$
\begin{aligned}
& x h_{i h m}+\theta_{i} \times x s_{i h m-1}-\sum_{j=1}^{J} x t_{i j h m}-x s_{i h m} \geq 0, \forall i, h, m . \\
& \sum_{m=1}^{12} \sum_{h=1}^{H} x h_{i h m}-\left(1-\theta_{i}\right) \times \sum_{m=1}^{12} \sum_{h=1}^{H} x s_{i h m}-\sum_{j=1}^{J} \sum_{h=1}^{H} \sum_{m=1}^{12} x t_{i j h m}=0, \forall i .
\end{aligned}
$$


$\sum_{h=1}^{H} x h_{i h m}-\sum_{h=1}^{H} x p s_{i h m}+\sum_{h=1}^{H} x s n_{i h m}-\sum_{h=1}^{H} \sum_{j=1}^{J} x t_{i j h m}=0, \forall i, m$.

Eq. (A.16) imposes the constraint that the quantity of switchgrass produced is subject to the availability of different land types that can be used to produce switchgrass, the potential yield of switchgrass on these lands, and the seasonal difference of switchgrass yield. $x s w_{w m}-\sum_{l=1}^{L} S M P_{m} \times S L P_{l} \times S W P_{l} \times A S_{w l} \leq 0, \forall w, m$.

Eqs. (A.17) - (A.19) are the constraints for switchgrass storage balance in the field, which are similar to the principles of logging residue storage at landings.

$$
\begin{aligned}
& x s w_{w m}+\theta_{w}^{\prime} \times x w_{w m-1}-\sum_{j=1}^{J} x t w_{w j m}-x w_{w m} \geq 0, \forall w, m . \\
& \sum_{m=1}^{12} x S w_{w m}-\left(1-\theta_{w}^{\prime}\right) \times \sum_{m=1}^{12} x w_{w m}-\sum_{j=1}^{J} \sum_{m=1}^{12} x t w_{w j m}=0, \forall w . \\
& x S w_{w m}-x p w_{w m}+x w n_{w m}-\sum_{j=1}^{J} x t w_{w j m}=0, \forall w, m .
\end{aligned}
$$

Eq. (A.20) restricts that the quantity of coal delivered to plants at any month is limited to the amount of coal after deducting the consumption of primary users (e.g. coal fired power plants) in the study region.

$$
\sum_{j=1}^{J} x c o_{w j m}-1000\left(Q C P_{w m}-Q C U_{w m}\right) \leq 0, \forall w, m
$$

Eq. (A.21) describes the total amount of feedstock (coal and biomass) delivered to plant $j$ in month $m\left(x f d_{c j m}\right)$ in terms of coal and biomass. 


$$
x f d_{c j m}=\left\{\begin{array}{l}
{\left[\sum_{i=1}^{I} \sum_{h=1}^{H}(1-\delta) \times x t_{i j h m}+\sum_{i=1}^{I} x m_{i j m}\right] \times(1-\sigma)+\sum_{w=1}^{W}(1-\kappa) \times x t w_{w j m}, \forall j, m, \text { where } c=\text { biomass }} \\
\sum_{w=1}^{W} x c o_{w j m}, \forall j, m, \text { where } c=\text { coal } .
\end{array}\right.
$$

Eq. (A.22) insures that the total amount of feedstock processed and stored at each plant should be balanced with the sum of all the feedstock delivered to the plant and the undeteriorated portion of the feedstock stored onsite from the previous month (Tembo et al. 2003). $x f d_{c j m}+\mu_{c} \times x s s_{c j m-1}-x p p_{c j m}-x s s_{c j m}=0, \forall c, j, m$.

Eq. (A.23) and Eq. (A.24) defines the minimum and maximum inventory at each plant, respectively, to ensure smooth production of the CBTL facility.

$$
\begin{aligned}
& x S S_{c j m}-M N B I N_{c} \times \beta_{j} \geq 0, \forall c, j, m . \\
& x S S_{c j m}-M X B I N_{c} \times \beta_{j} \leq 0, \forall c, j, m .
\end{aligned}
$$

Eq. (A.25) insures that the amount of feedstock processed $\left(x p p_{c j m}\right)$ in month $m$ at plant location $j$ is no less than the monthly feedstock demand $\left(\rho \times F N_{c}\right)$ at that location. $x p p_{c j m}-\rho \times F N_{c} \geq 0, \forall c, j, m$.

Eq. (A.26) states that the amount of liquid fuel $t$ produced at plant location $j$ in month $m$ $\left(q_{t j m}\right)$ is equal to the total amount of liquid fuels produced $\left(\sum_{c=1}^{C} \eta_{c} x p p_{c j m}\right)$ times the corresponding fuel proportion $\left(\gamma_{t}\right)$.

$q_{t j m}-\gamma_{t} \times \sum_{c=1}^{C} \eta_{c} \times x p p_{c j m}=0, \forall t, j, m$

Eq. (A.27) contains the non-negativity conditions for the decision variables. 
$x h, x t, x t l, x s, x p s, x s n, x m, x s w, x p w, x w, x t w, x t w l, x w n, x c o, x s s, x p p, x f d, q \geq 0$ 


\section{Appendix 4.B. Nomenclatures}

Table 4.B1. Data sets and descriptions.

\begin{tabular}{ll}
\hline Set & Description \\
\hline$C$ & Set of feedstock, $c=\{$ biomass, coal $\}$. \\
$H$ & $\begin{array}{l}\text { Set of woody biomass handling systems, } h=\{\text { cable skidder-loose residue, } \\
\text { cable skidder-chips, grapple skidder-loose residue, grapple skidder-chips }\} .\end{array}$ \\
& Set of woody biomass supply counties, $i=\{$ All the counties within West \\
& Virginia, Pennsylvania, Ohio, Virginia, Kentucky, and Maryland $\}.$ \\
$J$ & Set of plant locations, $j=\{$ Boone $\}$. \\
$L$ & Set of lands, $l=\{$ hayland, coalrelaimed $\}$. \\
$M$ & Set of months, $m=\{1,2,3, \ldots, 12\}$. \\
$S$ & Set of breakpoints, $s=\{0,1, \ldots, 9\}$. \\
$T$ & Set of FT liquid fuels, $t=\{$ diesel, naphtha $\}$. \\
$W$ & Set of switchgrass and coal supply counties, $w=\{$ All the counties in WV $\}$. \\
\hline
\end{tabular}


Table 4.B2. Parameters and descriptions.

\begin{tabular}{|c|c|}
\hline Parameter & Description \\
\hline$a_{s}$ & $\begin{array}{l}\text { A breakpoint over the quantity of annually delivered logging residue from } \\
\text { each supply county. }\end{array}$ \\
\hline$A S_{w l}$ & Area of land type $l_{\text {at county }} w\left(\mathrm{~km}^{2}\right)$ \\
\hline$B I V_{i}$ & Quantity of logging residue left after harvesting at supply location $i(\mathrm{t})$. \\
\hline$B P_{i}$ & $\begin{array}{l}\text { Proportion of logging residue available for extraction at supply location } \\
i(\%) .\end{array}$ \\
\hline$b_{s}$ & $\begin{array}{l}\text { A breakpoint over the quantity of annually delivered switchgrass from each } \\
\text { supply county. }\end{array}$ \\
\hline$C T$ & Unit transportation cost of coal $\left(\$ \mathrm{t}^{-1}\right)$. \\
\hline$C P_{h}$ & Grinding cost at a plant associated with system $h\left(\$ \mathrm{t}^{-1}\right)$. \\
\hline$C S_{h}$ & In-wood chipping cost associated with system $h\left(\$ \mathrm{t}^{-1}\right)$. \\
\hline$D_{i j}$ & Distance between supply location $i$ and plant $j(\mathrm{~km})$. \\
\hline$D_{w j}$ & Distance between supply location $w$ and plant $j(\mathrm{~km})$. \\
\hline$E X T_{m}$ & Percentage of logging residue extracted in month $m$ (\%). \\
\hline$f t$ & Federal tax rate applied to the CBTL facility. \\
\hline$F N_{c}$ & Quantity of feedstock ${ }^{c}$ needed per day (dry weight) $\left(\mathrm{t} \mathrm{day}^{-1}\right)$. \\
\hline$F C_{s}$ & Slope of the $s^{\text {th }}$ line segment in the range $\left(a_{s-1}, a_{s}\right)$. \\
\hline$F C_{s}^{\prime}$ & Slope of the $s^{\text {th }}$ line segment in the range $\left(b_{s-1}, b_{1}\right)$ \\
\hline$H C_{h}$ & Extraction cost of logging residue using system $h\left(\$ \mathrm{t}^{-1}\right)$. \\
\hline$L C_{h}$ & Loading cost of logging residue associated with system $h\left(\$ \mathrm{t}^{-1}\right)$. \\
\hline$M C$ & Purchase price of mill residue $\left(\$ \mathrm{t}^{-1}\right)$. \\
\hline MT & Round trip transportation cost rate of mill residue $\left(\$ \mathrm{t}^{-1} \mathrm{~km}^{-1}\right)$. \\
\hline$M I V_{i}$ & Quantity of mill residue produced at supply location $i(\mathrm{t})$. \\
\hline$M P_{i}$ & Proportion of mill residue available at supply location $i(\%)$. \\
\hline$M N B I N_{c}$ & Minimum inventory of feedstock $c$ at a plant (dry weight) (t). \\
\hline$M X B I N_{c}$ & Maximum inventory of feedstock $c$ at a plant (dry weight) (t). \\
\hline$N$ & Plant life (yr). \\
\hline$N L_{i}$ & Number of loggers in supply location $i$. \\
\hline$N M_{h}$ & Average number of extraction machines that a logging crew owns. \\
\hline$O M$ & Annual operating and maintenance cost $\left(\$ \mathrm{yr}^{-1}\right)$. \\
\hline$p$ & Construction period. \\
\hline$P C$ & Unit mining cost of coal $\left(\$ t^{-1}\right)$. \\
\hline$P D_{h}$ & Productivity of extraction machine associated with system $h\left(\mathrm{t} \mathrm{h}^{-1}\right)$. \\
\hline$Q C P_{w m}$ & Quantity of coal produced monthly at location $w(1,000 \mathrm{t})$. \\
\hline
\end{tabular}


Table 4.B2. Parameters and descriptions (continued).

\begin{tabular}{|c|c|}
\hline Parameter & Description \\
\hline$Q C U_{w m}$ & Quantity of coal consumed monthly at location $w(1,000 \mathrm{t})$. \\
\hline$r$ & Rate of inflation ( $r=1.13 \%$ in this paper). \\
\hline$R_{e}$ & Cost of equity. \\
\hline$R_{d}$ & Cost of debt. \\
\hline$R S_{i}$ & $\begin{array}{l}\text { One half of the furthest straight-line distance (e.g., from the east to west) of } \\
\text { supply county } i(\mathrm{~km}) \text {. }\end{array}$ \\
\hline$R S_{w}$ & One half of the furthest straight-line distance of supply county $w(\mathrm{~km})$. \\
\hline$S C$ & Storage cost of logging residue in the field $\left(\left(\$ t^{-1}\right)\right.$. \\
\hline$S P$ & Stumpage cost of logging residue $\left(\$ \mathrm{t}^{-1}\right)$. \\
\hline$S C P$ & Grinding cost of switchgrass at a plant $\left(\$ \mathrm{t}^{-1}\right)$. \\
\hline$S W C$ & $\begin{array}{l}\text { The cost of switchgrass associated with establishment, growth, and harvest } \\
\text { activities }\left(\$ \mathrm{t}^{-1}\right) \text {. }\end{array}$ \\
\hline SWS & Unit storage cost of switchgrass in the field $\left(\$ t^{-1}\right)$. \\
\hline$S W T_{w j}$ & $\begin{array}{l}\text { Round trip transportation cost of switchgrass from supply location } w \text { to } \\
\text { plant } j\left(\$ \mathrm{t}^{-1}\right) \text {. }\end{array}$ \\
\hline$S M P_{m}$ & Proportion of potential yield of switchgrass by harvest month (\%). \\
\hline$S L P_{l}$ & Proportion of land type $l$ that can be used to produce switchgrass (\%). \\
\hline$S W P_{l}$ & Potential yield of switchgtrass on land type $l\left(\mathrm{t} \mathrm{km}^{-2}\right)$. \\
\hline$T C_{i j h}$ & $\begin{array}{l}\text { Round trip transportation cost from supply location } i \text { to plant } j \text { for system } \\
h\left(\$ \mathrm{t}^{-1}\right) \text {. }\end{array}$ \\
\hline$T_{h}$ & $\begin{array}{l}\text { Off-highway transportation cost rate of woody biomass for system } h\left(\$ \mathrm{t}^{-}\right. \\
\left.{ }^{1} \mathrm{~km}^{-1}\right) \text {. }\end{array}$ \\
\hline TSW & Off-highway transportation cost rate of switchgrass $\left(\$ \mathrm{t}^{-1} \mathrm{~km}^{-1}\right)$. \\
\hline$T P C$ & Total investment cost of a coal/biomass-to-liquids plant (\$). \\
\hline$w_{e}$ & Percentage of financing that is equity (\%). \\
\hline WACC & Weighted average cost of capital. \\
\hline$\lambda$ & Monthly productive time per machine (h). \\
\hline$\sigma$ & Moisture content of woody biomass (\%). \\
\hline$\eta_{c}$ & $\begin{array}{l}\text { Potential yield of liquid fuels produced from one tonne of feedstock }{ }^{c}\left(\mathrm{bbl} \mathrm{t}{ }^{-}\right. \\
\left.{ }^{1}\right) \text {. }\end{array}$ \\
\hline$\gamma_{t}$ & Liquid fuel product $t$ as a percentage of the total fuels (\%). \\
\hline$\rho$ & Scheduled working days of the plant per month (days). \\
\hline$\delta$ & Rate of matter loss due to transportation (\%). \\
\hline$\kappa$ & Moisture content of switchgrass (\%). \\
\hline$\theta_{i}$ & Usable proportion of logging residue stored at supply location ${ }^{i}(\%)$. \\
\hline$\theta_{w}^{\prime}$ & Usable proportion of switchgrass stored at supply location $w(\%)$. \\
\hline$\mu_{c}$ & Usable proportion of feedstock ${ }^{c}$ at the plant (\%). \\
\hline$\psi$ & Plant maintenance factor. \\
\hline$\zeta$ & Amortization factor. \\
\hline
\end{tabular}


Table 4.B3. Variables and descriptions.

\begin{tabular}{|c|c|}
\hline Variable & Description \\
\hline$A L F A_{i h}$ & $\begin{array}{l}\text { A binary variable related to biomass handling system } h \text { at supply location } \\
i, A L F A_{i h}=\{0,1\} \text {. }\end{array}$ \\
\hline$\beta_{j}$ & A binary variable related to plant $j, \beta_{j}=\{0,1\}$ \\
\hline$F$ & Annual feedstock cost $\left(\$ \mathrm{yr}^{-1}\right)$ \\
\hline$L C T_{1}$ & Under-estimated transportation cost of logging residue $\left(\$ \mathrm{yr}^{-1}\right)$. \\
\hline$L C T_{2}$ & Under-estimated transportation cost of switchgrass $\left(\$ \mathrm{yr}^{-1}\right)$. \\
\hline$O B J$ & Annual production cost of liquid fuels $\left(\$ \mathrm{yr}^{-1}\right)$. \\
\hline$q_{t j m}$ & Quantity of liquid fuel products produced at plant $j$ in month $m$ (bbl). \\
\hline$x f d_{c j m}$ & Quantity of feedstock $c$ delivered to plant $j$ in month $m$ (dry weight) (t). \\
\hline$x h_{i h m}$ & $\begin{array}{l}\text { Quantity of logging residue extracted at supply location } i \text { using system } h \text { in } \\
\text { month } m \text { (t). }\end{array}$ \\
\hline$x t_{i j h m}$ & $\begin{array}{l}\text { Quantity of logging residue extracted using system } h \text { and delivered from } \\
\text { supply location } i \text { to plant } j \text { in month } m(\mathrm{t}) \text {. }\end{array}$ \\
\hline$x p s_{i h m}$ & $\begin{array}{l}\text { Quantity of logging residue extracted using system } h \text { and entered into } \\
\text { storage at supply location } i \text { in month } m(\mathrm{t}) \text {. }\end{array}$ \\
\hline$x s_{i h m}$ & $\begin{array}{l}\text { Quantity of logging residue extracted using system } h \text { and stored at supply } \\
\text { location } i \text { in month } m(\mathrm{t}) \text {. }\end{array}$ \\
\hline$x s n_{i h m}$ & $\begin{array}{l}\text { Quantity of logging residue extracted using system } h \text { and removed from } \\
\text { storage at supply location } i \text { in month } m(\mathrm{t}) \text {. }\end{array}$ \\
\hline$x m_{i j m}$ & $\begin{array}{l}\text { Quantity of mill residue delivered from supply location } i \text { to plant } j \text { in } \\
\text { month } m(\mathrm{t}) \text {. }\end{array}$ \\
\hline$x s w_{w m}$ & Quantity of switchgrass harvested in supply location $w$ in month $m(\mathrm{t})$. \\
\hline$x p w_{w m}$ & $\begin{array}{l}\text { Quantity of switchgrass entered into storage at supply location } w \text { in month } \\
m(\mathrm{t}) \text {. }\end{array}$ \\
\hline$x t w_{w j m}$ & $\begin{array}{l}\text { Quantity of switchgrass delivered from supply location } w \text { to plant } j \text { in } \\
\text { month } m(\mathrm{t}) \text {. }\end{array}$ \\
\hline$x w_{w m}$ & Quantity of switchgrass stored at supply location $w$ in month $m(\mathrm{t})$. \\
\hline$x w n_{w m}$ & Quantity of switchgrass removed from supply location $w$ in month $m(\mathrm{t})$. \\
\hline$x c o_{\text {wjm }}$ & $\begin{array}{l}\text { Quantity of coal delivered from supply location } w \text { to plant } j \text { in month } m \\
\text { (t). }\end{array}$ \\
\hline$x t l_{i j h s}$ & $\begin{array}{l}\text { Increment of logging residue annually shipped out of supply county } i \text { in the } \\
\text { range }\left(a_{s-1}, a_{s}\right)\end{array}$ \\
\hline$x t w l_{w j s}$ & $\begin{array}{l}\text { Increment of switchgrass annually shipped out of supply county } w \text { in the } \\
\text { range }\left(b_{s-1}, b_{s}\right) \text {. }\end{array}$ \\
\hline$x p p_{c j m}$ & $\begin{array}{l}\text { Quantity of feedstock } c \text { processed at plant location } j \text { in month } m \text { (dry } \\
\text { weight) (t). }\end{array}$ \\
\hline$x s S_{c j m}$ & $\begin{array}{l}\text { Quantity of feedstock } c \text { stored at plant location } j \text { in month } m \text { (dry weight) } \\
(\mathrm{t}) \text {. }\end{array}$ \\
\hline
\end{tabular}




\section{CHAPTER 5: SUMMARY}

Three mixed integer programming models were developed to assess the economics of woody biomass to biofuels and applied in the central Appalachian region. Based on the modeling processes, case scenarios, and sensitivity analyses, the following conclusions can be drawn:

(1) The average delivered cost of woody biomass for a base case plant with daily demand of 900 metric tons (990 short tons) of dry woody biomass in central Appalachia ranged from \$2.77- \$3.01 per GJ (\$44.07 to $\$ 47.77$ per short ton) using the different woody biomass handling systems. Factors such as woody biomass demand level at the plant, purchase price of mill residue, and mill residue availability had greater impacts on the average delivered cost of woody biomass, while skidding distance had the least impact. These findings could be useful to help researchers assess woody biomass utilization for bioenergy in other regions.

(2) Considering site selection criteria for a woody biomass-based ethanol plant including feedstock availability, utilities (such as electricity, gas, and water) availability and cost, transportation, site size, product market, community support, and other optimized results, the optimal biomass plant location should be in Buckhannon, West Virginia. With the assumptions of 1,814 dry metric tons/day of woody biomass requirement, a 20 year plant life, and equity/debt ratio of $40 / 60$, the net present value (NPV) of the plant would vary from $\$ 17.28$ million for the cable skidder-chips system to $\$ 35.54$ million for the grapple skidder-chips system. The production cost of ethanol varied from USф 50.85/liter ( $\$ 1.92$ per gallon or $\$ 24.27 / \mathrm{GJ})$ for the grapple skidder-chips system to US $\notin 52.38 /$ liter $(\$ 1.98$ per gallon or $\$ 25.03 / \mathrm{GJ})$ for the cable skidder-chips system. Ethanol production cost can be significantly affected by biomass availability, plant investment and capacity, ethanol yield, and financial structure. Our study 
indicated that a woody biomass-based ethanol facility in central Appalachia could be economically feasible under certain operational scenarios.

(3) The production of liquid fuels from coal and biomass is another way of utilizing biomass resources, which provides an option of reducing the U.S. dependence on foreign oil and enhancing national and economic security. Our study suggested that the required selling price (RSP) of Fischer-Tropsch (FT) liquid fuels for a 40,000 barrel per day (BPD) plant in central Appalachia varied between $\$ 79.30 / \mathrm{bbl}(\$ 13.77 / \mathrm{GJ})$ and $\$ 79.57 / \mathrm{bbl}(\$ 13.82 / \mathrm{GJ})$ among four biomass handling systems with coal/biomass ratio of $85 / 15$, or between $\$ 79.30 / \mathrm{bbl}(\$ 13.77 / \mathrm{GJ})$ and $\$ 83.87 / \mathrm{bbl}(\$ 14.56 / \mathrm{GJ})$ among different coal/biomass ratios $(85 / 15,80 / 20,75 / 25,70 / 30)$ using the grapple skidder-chips system. The RSP was heavily dependent on plant capacity, capital cost, mine-mouth price of coal, and liquid fuel yield from coal and biomass. The liquid fuels from coal and biomass would be cost-competitive with oil priced at $\$ 62 / \mathrm{bbl}$. These results can help decision-makers evaluate future CBTL developments in central Appalachia.

Recently, much attention has been given to the production of biofuels. Based on results from this study, the following suggestions for future research are proposed:

(1) Environmental impacts of biofuel production

Fossil fuel energy used in the whole biofuel production chain should be determined and used to calculate the net energy benefit associated with the biofuel. The life cycle assessment (LCA), also known as a cradle-to-grave analysis, can be used to investigate and estimate greenhouse gas emissions of the biofuel production chain. Other environmental factors that need to be considered include soil health and quality, water use and quality, waste water and solid waste streams.

(2) Sustainability of biomass supply 
Accurately estimating long-term supply of biomass for a biomass-based plant presents challenges. Changes in current and future conditions will significantly impact the availability of biomass at any given price range. Factors such as the price of fuel, technological advancements, competition for limited biomass supply, and efficiencies of biomass conversion to energy should be considered. Sustainable woody biomass removal rates need to be determined and should be considered part of the best management practices. 


\section{APPENDIX I: WOODY BIOMASS DELIVERED COST MODEL}

\section{I.1 Introduction to GAMS}

The General Algebraic Modeling System (GAMS) is a high-level modeling system for mathematical programming and optimization. It consists of a language compiler and a stable of integrated high-performance solvers.

\section{I.2 System requirement}

To run the delivered cost model, the following requirements must be met:

- The GAMS system must be installed in a computer. For more detailed instruction, please go to http://www.gams.com/default.htm.

- A GAMS/Cplex license file must be presented.

\section{I.3 Source code}

Sontext

This program is used to determine the delivered cost of woody biomass at the utilization plant given the daily feedstock requirement. The objective function is to minimize the total cost, which includes extracting, storage, transportation, and chipping/grinding cost.

Programmed by Jinzhuo $\mathrm{Wu}$

Division of Forestry and Natural Resources

West Virginia University

Oct 28, 2008

\$offtext

\$OFFSYMLIST OFFSYMXREF

OPTION LIMCOL $=0$;

OPTION LIMROW $=0$;

OPTION SOLSLACK $=1$;

\section{Sets}

I Logging residue supply locations in West Virginia

/Barbour, Boone, Braxton, Cabell, Calhoun, Clay, Doddridge, Fayette, Gilmer, Grant, Greenbrier, Hampshire, Hardy, Harrison, Jackson, Kanawha, Lewis, Lincoln, Logan, McDowell, Marion, Marshall, Mason, Mercer, Mineral, Mingo, Monongalia, Monroe, Nicholas, Pendleton, Pleasants, Pocahontas, Preston, Putnam, Raleigh, Randolph, Ritchie, Roane, Summers, Taylor, Tucker, Tyler, Upshur, Wayne, Webster, Wetzel, Wirt, Wood, Wyoming/

$\mathrm{J}$ Potential locations for the woody biomass processing plant in WV

/Grafton, Moorefield, Addison, Mabscott, Alum_creek, Grantsville/

M Months of the production year

/Jan, Feb, Mar, Apr, May, Jun, Jul, Aug, Sep, Oct, Nov, Dec/

$\mathrm{H}$ Logging residue handling systems

/Cable-skidder, Cableskidder-chip, Grapple-skidder, Grappleskidder-chip, Forwarder-loose, Forwarder-chip, Forwarder-bundle/ 
$\mathrm{R}$ Mill reisdue types

/Bark, Chips, Sawdust, planer-shavings,slabs, others/

LogStat Logging residues related statistics for each county

/Quantities, SlopeLess35, IntraDistance/

SI Separated line segment index for nonlinear programming $/ 1 * 9 /$;

$* * * * * * * * * * * * * * * * * * * * * * * * * * * * * * * * * * * * * * * * * * * * * * * * * * * * * * * * * * * * * * * * * * * * * * * * * * * * * *$

* Hourly machine cost is calculated by using the Machine Rate method

*********************************************************************************

Scalar BundlerCost Hourly cost of slash bundler in US dollars /205.51/;

Parameter MC(H) Hourly cost of extraction machine (\$ per PMH)

$\begin{array}{ll}\text { /Cable-skidder } & 81.34 \\ \text { Cableskidder-chip } & 81.34 \\ \text { Grapple-skidder } & 102.72 \\ \text { Grappleskidder-chip } & 102.72 \\ \text { Forwarder-loose } & 124.35 \\ \text { Forwarder-chip } & 124.35 \\ \text { Forwarder-bundle } & 145.14 / \text {; }\end{array}$

Parameter $\operatorname{AED}(\mathrm{H})$ Average extraction distance (feet);

$\operatorname{AED}(\mathrm{H})=984$;

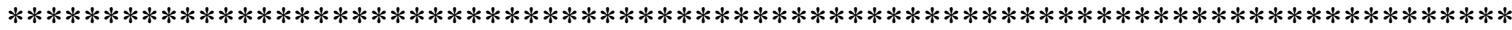

*The average payload sizes for a cable skidder, a grapple skidder, and a forwarder are from $\quad *$ * Shawn et al. 2007. Influence of site characteristics and cost of extraction and trucking on * * logging residue utilization in southern West Virginia. Payload size of bundles for forwarder is * *assumed to be 4 bone dry ton per cycle.

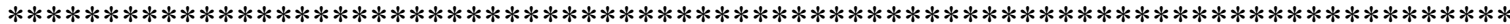

Parameter PL(H) Average payload size (cubic foot)

/Cable-skidder $\quad 106$

Cableskidder-chip $\quad 106$

Grapple-skidder $\quad 107.87$

Grappleskidder-chip $\quad 107.87$

Forwarder-loose $\quad 300$

Forwarder-chip $\quad 300$

Forwarder-bundle $\quad 420$ /;

Scalar PB Slash bundler productivity in green tons per hour /13/;

Scalar BZ Bunch size (cubic foot) /54/;

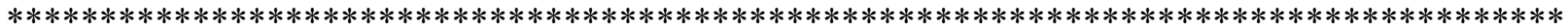

*The following equations are from: Li, Y., Wang, J., Miller, G., and McNeel, J. 2006. Production * *economics of harvesting small-diameter hardwood stands in central Appalachia. Forest * *Products Journal 56(3), 81-86.

***************************************************************************************** 
Parameter $\mathrm{PD}(\mathrm{H})$ Productivity of extraction machine (cubic foot per hour);

$\mathrm{PD}(\mathrm{H}) \$(\mathrm{ORD}(\mathrm{H}) \mathrm{LE} 2)=144.22-0.00001 * \mathrm{AED}(\mathrm{H}) * * 2+1.60 * \mathrm{PL}(\mathrm{H})-1087.54 / \mathrm{PL}(\mathrm{H})$ $-0.0003 * \mathrm{PL}(\mathrm{H}) * * 2$;

$\mathrm{PD}(\mathrm{H}) \$(\mathrm{ORD}(\mathrm{H}) \mathrm{EQ} 3$ or $\mathrm{ORD}(\mathrm{H}) \mathrm{EQ} 4)=505.88-0.00004 * \mathrm{AED}(\mathrm{H}) * * 2+$ $0.005 * \mathrm{PL}(\mathrm{H}) * 2$;

$\mathrm{PD}(\mathrm{H}) \$(\mathrm{ORD}(\mathrm{H})$ EQ 5 or ORD $(\mathrm{H}) \mathrm{EQ} 6)=831.29-0.00005 * \mathrm{AED}(\mathrm{H}) * \mathrm{AED}(\mathrm{H})-$ $5.2 * \mathrm{PL}(\mathrm{H})+0.009 * \mathrm{PL}(\mathrm{H}) * \mathrm{PL}(\mathrm{H})+15.04 * \mathrm{BZ}-0.09 * \mathrm{BZ} * \mathrm{BZ}$;

$\mathrm{PD}(\mathrm{H}) \$(\mathrm{ORD}(\mathrm{H}) \mathrm{EQ} 7)=703$;

$*$ The extraction costs are converted to the unit of $\$$ per green ton

$* * * * * * * * * * * * * * * * * * * * * * * * * * * * * * * * * * * * * * * * * * * * * * * * * * * * * * * * * * * * * * * * * * * * * * * * * * * * * * *$

Parameter $\mathrm{EC}(\mathrm{H})$ Extraction cost for each system (\$ per green ton);

$\mathrm{EC}(\mathrm{H}) \$(\mathrm{ORD}(\mathrm{H}) \mathrm{LE} 6)=\mathrm{MC}(\mathrm{H}) /(\mathrm{PD}(\mathrm{H}) / 35.3 * 0.77)$

$\mathrm{EC}(\mathrm{H}) \$(\mathrm{ORD}(\mathrm{H}) \mathrm{EQ} 7)=4.672+0.0092 * \mathrm{AED}(\mathrm{H}) / 3.28$

Parameters $\mathrm{BC}(\mathrm{H}) \quad$ Bundling cost for each system (\$ per green ton);

$\mathrm{BC}(\mathrm{H}) \$(\mathrm{ORD}(\mathrm{H}) \mathrm{LE} 6)=0$

$\mathrm{BC}(\mathrm{H}) \$(\mathrm{ORD}(\mathrm{H})$ EQ 7)=BundlerCost/PB;

Scalar Loader_Cost Hourly cost of loader (\$ per hour) /85.96/;

Scalar Bundle_D Small end diameter of a slash bundle (inch) $/ 22 /$;

Scalar Logres D Small end diameter of slash /5/;

Scalar NL Number of small logs or slash grappled per turn /5/;

Parameter LC(H) Average loading cost corresponding to harvesting system (\$ per ton);

$\mathrm{LC}(\mathrm{H}) \$(\mathrm{ORD}(\mathrm{H}) \mathrm{LE} 6)=$ Loader_cost $/((-10.14+1.23 *$ Logres_D+1.7058*NL $)$

$* 162 / 3 \overline{5} .3 * 0.77)$

$\mathrm{LC}(\mathrm{H}) \$(\mathrm{ORD}(\mathrm{H}) \mathrm{EQ} 7)=0$;

Parameter Cost_Chipper(H) Hourly chipping or grinding cost (\$)

/Cable-skidder $\quad 212.27$

Cableskidder-chip $\quad 185.62$

Grapple-skidder $\quad 212.27$

Grappleskidder-chip $\quad 185.62$

Forwarder-loose $\quad 212.27$

Forwarder-chip $\quad 185.62$

Forwarder-bundle $\quad 237.05$ /;

Parameter Productivity_Chipper(H) Hourly chipping or grinding productivity (green tons)

$\begin{array}{ll}\text { /Cable-skidder } & 91 \\ \text { Cableskidder-chip } & 30 \\ \text { Grapple-skidder } & 91 \\ \text { Grappleskidder-chip } & 30 \\ \text { Forwarder-loose } & 91 \\ \text { Forwarder-chip } & 30 \\ \text { Forwarder-bundle } & 120 / \text {; }\end{array}$


Parameter ChippingSite $(\mathrm{H})$ Chipping cost on forest landings (\$ per ton);

ChippingSite(H)\$ (ORD(H) EQ 1 OR ORD(H) EQ 3 OR ORD(H) EQ 5 OR ORD(H) EQ 7 ) = 0;

ChippingSite $(\mathrm{H}) \$(\mathrm{ORD}(\mathrm{H})$ EQ 2 OR ORD(H) EQ 4 OR ORD(H) EQ 6)

$=$ Cost_Chipper $(\mathrm{H}) /$ Productivity_Chipper $(\mathrm{H})$;

Parameter ChippingPlant $(\mathrm{H})$ Chipping cost at the plant (\$ per green ton);

ChippingPlant $(\mathrm{H}) \$(\mathrm{ORD}(\mathrm{H})$ EQ 2 OR ORD $(\mathrm{H})$ EQ 4 OR ORD $(\mathrm{H})$ EQ 6) $=0$;

ChippingPlant $(\mathrm{H}) \$(\mathrm{ORD}(\mathrm{H})$ EQ 1 OR ORD(H) EQ 3 OR ORD(H) EQ 5 OR ORD(H) EQ 7 )

$=$ Cost_Chipper $(\mathrm{H}) /$ Productivity_Chipper $(\mathrm{H})$;

Table LoggingResidue(I,LogStat) Logging residues statistics by county(quantities in green tons) 


$\begin{array}{llll}\text { Summers } & 12775 & 0.59 & 12 \\ \text { Taylor } & 23885 & 1.00 & 9 \\ \text { Tucker } & 36716 & 0.77 & 15 \\ \text { Tyler } & 23575 & 0.86 & 10 \\ \text { Upshur } & 65941 & 0.84 & 14 \\ \text { Wayne } & 22491 & 0.73 & 19 \\ \text { Webster } & 88773 & 0.53 & 16 \\ \text { Wetzel } & 47065 & 0.61 & 13 \\ \text { Wirt } & 39527 & 0.90 & 9 \\ \text { Wood } & 30324 & 1.00 & 14 \\ \text { Wyoming } & 30324 & 0.43 & 15\end{array}$

Scalar BP Proportion of woody biomass that can be economically harvested /0.65/;

Parameter Loggingavai(I) Logging residues in tons for each supply location; Loggingavai(I)=LoggingResidue(I,"Quantities")*BP ;

Parameter LoggingSlope(I) Logging residues at sites with less than 35 percent slope; loggingSlope(I)=Loggingavai(I)*LoggingResidue(I,"SlopeLess35");

Scalar Logres_mc Logging residue moisture content /0.43/;

Parameter ExtProp(M) Extracted proportion as a percentage of the whole year

$\begin{array}{ll}\text { Jan } & 0.083 \\ \text { Feb } & 0.083 \\ \text { Mar } & 0.083 \\ \text { Apr } & 0.083 \\ \text { May } & 0.075 \\ \text { Jun } & 0.075 \\ \text { Jul } & 0.075 \\ \text { Aug } & 0.075 \\ \text { Sep } & 0.092 \\ \text { Oct } & 0.092 \\ \text { Nov } & 0.092 \\ \text { Dec } & 0.092\end{array}$

Parameter Ext_amt $(\mathrm{I}, \mathrm{M})$ Extraction limit per month by county in green tons; Ext_amt(I,M)=loggingSlope(I)* ExtProp(M);

* Proportion of available woody biomass on site *************************************************************************************** Scalar UPS Usable proportion of logging residues at supply locations /0.95/;

Scalar Stumpage Stumpage cost of logging residues in dollar per ton /0.91/;

Scalar SC Storage cost for logging residues in dollar per ton /0.00/;

Table MillResidue(I, R) Amounts of mill residues per week by county in green tons

$\begin{array}{lllllll} & \text { Bark } & \text { Chips } & \text { Sawdust } & \text { Planer-shavings } & \text { Slabs } & \text { Others } \\ \text { Barbour } & 150 & 200 & 200 & 0 & 0 & 0 \\ \text { Boone } & 0 & 0 & 0 & 0 & 0 & 0\end{array}$




\begin{tabular}{|c|c|c|c|c|c|c|}
\hline Braxton & 388 & 440 & 380 & 30 & 0 & 81 \\
\hline Cabell & 0 & 0 & 0 & 0 & 0 & 0 \\
\hline Calhoun & 0 & 0 & 0 & 0 & 0 & 0 \\
\hline Clay & 120 & 268 & 140 & 0 & 0 & 0 \\
\hline Doddridge & 130 & 125 & 140 & 0 & 40 & 0 \\
\hline Fayette & 135 & 215 & 160 & 0 & 0 & 0 \\
\hline Gilmer & 0 & 0 & 1 & 0 & 25 & 5 \\
\hline Grant & 0 & 0 & 72 & 0 & 0 & 0 \\
\hline Greenbrier & 1375 & 480 & 887 & 0 & 0 & 0 \\
\hline Hampshire & 0 & 0 & 0 & 0 & 0 & 0 \\
\hline Hardy & 45 & 25 & 31 & 0 & 2 & 0 \\
\hline Harrison & 0 & 0 & 0 & 0.5 & 0 & 0 \\
\hline Jackson & 0 & 0 & 60 & 0 & 0 & 0 \\
\hline Kanawha & 280 & 565 & 340 & 0 & 0 & 0 \\
\hline Lewis & 0 & 0 & 12 & 0 & 40 & 0 \\
\hline Lincoln & 0 & 0 & 0 & 0 & 0 & 0 \\
\hline Logan & 0 & 0 & 0 & 0 & 0 & 0 \\
\hline McDowell & 0 & 0 & 0 & 0 & 0 & 0 \\
\hline Marion & 0 & 0 & 0 & 0 & 0 & 0 \\
\hline Marshall & 0 & 0 & 0 & 0 & 0 & 0 \\
\hline Mason & 0 & 0 & 0 & 0 & 0 & 0 \\
\hline Mercer & 0 & 0 & 20 & 0 & 0 & 40 \\
\hline Mineral & 0 & 0 & 100 & 0 & 20 & 0 \\
\hline Mingo & 300 & 763 & 445.1 & 0 & 15 & 0 \\
\hline Monongalia & 0 & 0 & 1 & 0 & 0.5 & 0 \\
\hline Monroe & 80 & 110 & 60 & 0 & 0 & 0 \\
\hline Nicholas & 932 & 2595 & 598 & 6 & 0 & 8 \\
\hline Pendleton & 85 & 300 & 100 & 0 & 0 & 0 \\
\hline Pleasants & 0 & 0 & 0 & 0 & 0 & 0 \\
\hline Pocahontas & 865 & 863 & 735 & 50 & 0 & 0 \\
\hline Preston & 652 & 1252 & 858 & 0 & 11 & 0 \\
\hline Putnam & 0 & 0 & 0 & 0 & 0 & 0 \\
\hline Raleigh & 250 & 500 & 350 & 10 & 0 & 0 \\
\hline Randolph & 767.67 & 1170 & 3269.66 & 0 & 2 & 61 \\
\hline Ritchie & 15.63 & 41.67 & 20.83 & 0 & 0 & 0 \\
\hline Roane & 0 & 0 & 10 & 0 & 0 & 130 \\
\hline Summers & 100 & 100 & 100 & 0 & 0 & 0 \\
\hline Taylor & 0 & 5 & 10 & 0 & 0 & 0 \\
\hline Tucker & 0 & 0 & 0 & 0 & 0 & 0 \\
\hline Tyler & 0 & 0 & 0 & 0 & 0 & 0 \\
\hline Upshur & 0 & 600 & 550 & 0.125 & 24 & 20 \\
\hline Wayne & 0 & 0 & 0 & 0 & 0 & 0 \\
\hline Webster & 147 & 150 & 147 & 0 & 8 & 0 \\
\hline Wetzel & 364.5 & 110 & 50 & 0 & 0 & 0 \\
\hline Wirt & 0 & 0 & 0 & 0 & 0 & 0 \\
\hline Wood & 0 & 0 & 3.02 & 0 & 8.25 & 1 \\
\hline Wyoming & 0 & 0.2 & 0.1 & 0.05 & 0 & 0 \\
\hline
\end{tabular}

Parameter MillProp(I) Proportion of mill residues available in each county; $\operatorname{MillProp}(\mathrm{I})=0.4$; 
Table DIS(I,J) Distance from supply source $\mathrm{i}$ to demand location $\mathrm{j}$

\begin{tabular}{|c|c|c|c|c|c|}
\hline & Grafton & Moorefield & Addison & Mabscott & Alum_creek \\
\hline Barbour & 13.000 & 58.000 & 51.000 & 115.000 & 113.000 \\
\hline Boone & 131.000 & 169.000 & 81.000 & 38.000 & 14.000 \\
\hline Braxton & 61.000 & 100.000 & 21.000 & 68.000 & 62.000 \\
\hline Cabell & 130.000 & 177.000 & 94.000 & 68.000 & 19.000 \\
\hline Calhoun & 65.000 & 115.000 & 48.000 & 80.000 & 60.000 \\
\hline Clay & 83.000 & 121.000 & 36.000 & 48.000 & 43.000 \\
\hline Doddridge & 41.000 & 98.000 & 60.000 & 108.000 & 90.000 \\
\hline Fayette & 107.000 & 134.000 & 48.000 & 20.000 & 43.000 \\
\hline Gilmer & 52.000 & 100.000 & 39.000 & 83.000 & 71.000 \\
\hline Grant & 53.000 & 9.000 & 78.000 & 141.000 & 155.000 \\
\hline Greenbrier & 102.000 & 120.000 & 38.000 & 32.000 & 67.000 \\
\hline Hampshire & 68.000 & 23.000 & 107.000 & 172.000 & 182.000 \\
\hline Hardy & 60.000 & 0.000 & 87.000 & 151.000 & 162.000 \\
\hline Harrison & 18.000 & 75.000 & 55.000 & 115.000 & 105.000 \\
\hline Jackson & 98.000 & 148.000 & 74.000 & 77.000 & 39.000 \\
\hline Kanawha & 108.000 & 147.000 & 61.000 & 41.000 & 18.000 \\
\hline Lewis & 32.000 & 80.000 & 39.000 & 97.000 & 90.000 \\
\hline Lincoln & 134.000 & 177.000 & 93.000 & 60.000 & 17.000 \\
\hline Logan & 148.000 & 183.000 & 96.000 & 43.000 & 29.000 \\
\hline McDowell & 157.000 & 181.000 & 96.000 & 31.000 & 60.000 \\
\hline Marion & 17.000 & 75.000 & 72.000 & 131.000 & 120.000 \\
\hline Marshall & 45.000 & 100.000 & 93.000 & 146.000 & 127.000 \\
\hline Mason & 112.000 & 162.000 & 86.000 & 79.000 & 35.000 \\
\hline Mercer & 148.000 & 164.000 & 85.000 & 28.000 & 72.000 \\
\hline Mineral & 46.000 & 24.000 & 92.000 & 158.000 & 164.000 \\
\hline Mingo & 163.000 & 197.000 & 110.000 & 53.000 & 46.000 \\
\hline Monongalia & 21.000 & 72.000 & 82.000 & 146.000 & 132.000 \\
\hline Monroe & 124.000 & 133.000 & 62.000 & 36.000 & 85.000 \\
\hline Nicholas & 85.000 & 115.000 & 27.000 & 41.000 & 54.000 \\
\hline Pendleton & 61.000 & 38.000 & 59.000 & 119.000 & 133.000 \\
\hline Pleasants & 63.000 & 122.000 & 77.000 & 113.000 & 85.000 \\
\hline Pocahontas & 77.000 & 83.000 & 25.000 & 69.000 & 92.000 \\
\hline Preston & 23.000 & 48.000 & 81.000 & 146.000 & 141.000 \\
\hline Putnam & 116.000 & 161.000 & 80.000 & 64.000 & 17.000 \\
\hline Raleigh & 126.000 & 151.000 & 64.000 & 0.000 & 49.000 \\
\hline Randolph & 35.000 & 50.000 & 38.000 & 104.000 & 113.000 \\
\hline Ritchie & 56.000 & 112.000 & 61.000 & 100.000 & 77.000 \\
\hline Roane & 81.000 & 129.000 & 56.000 & 72.000 & 44.000 \\
\hline Summers & 125.000 & 141.000 & 62.000 & 19.000 & 64.000 \\
\hline Taylor & 0.000 & 60.000 & 63.000 & 126.000 & 121.000 \\
\hline Tucker & 29.000 & 34.000 & 59.000 & 124.000 & 130.000 \\
\hline Tyler & 49.000 & 108.000 & 75.000 & 120.000 & 98.000 \\
\hline Upshur & 27.000 & 67.000 & 36.000 & 100.000 & 98.000 \\
\hline Wayne & 152.000 & 196.000 & 112.000 & 74.000 & 36.000 \\
\hline Webster & 63.000 & 87.000 & 0.000 & 66.000 & 76.000 \\
\hline Wetzel & 39.000 & 97.000 & 76.000 & 127.000 & 109.000 \\
\hline Wirt & 77.000 & 130.000 & 67.000 & 90.000 & 59.000 \\
\hline Wood & 81.000 & 135.000 & 77.000 & 99.000 & 65.000 \\
\hline
\end{tabular}




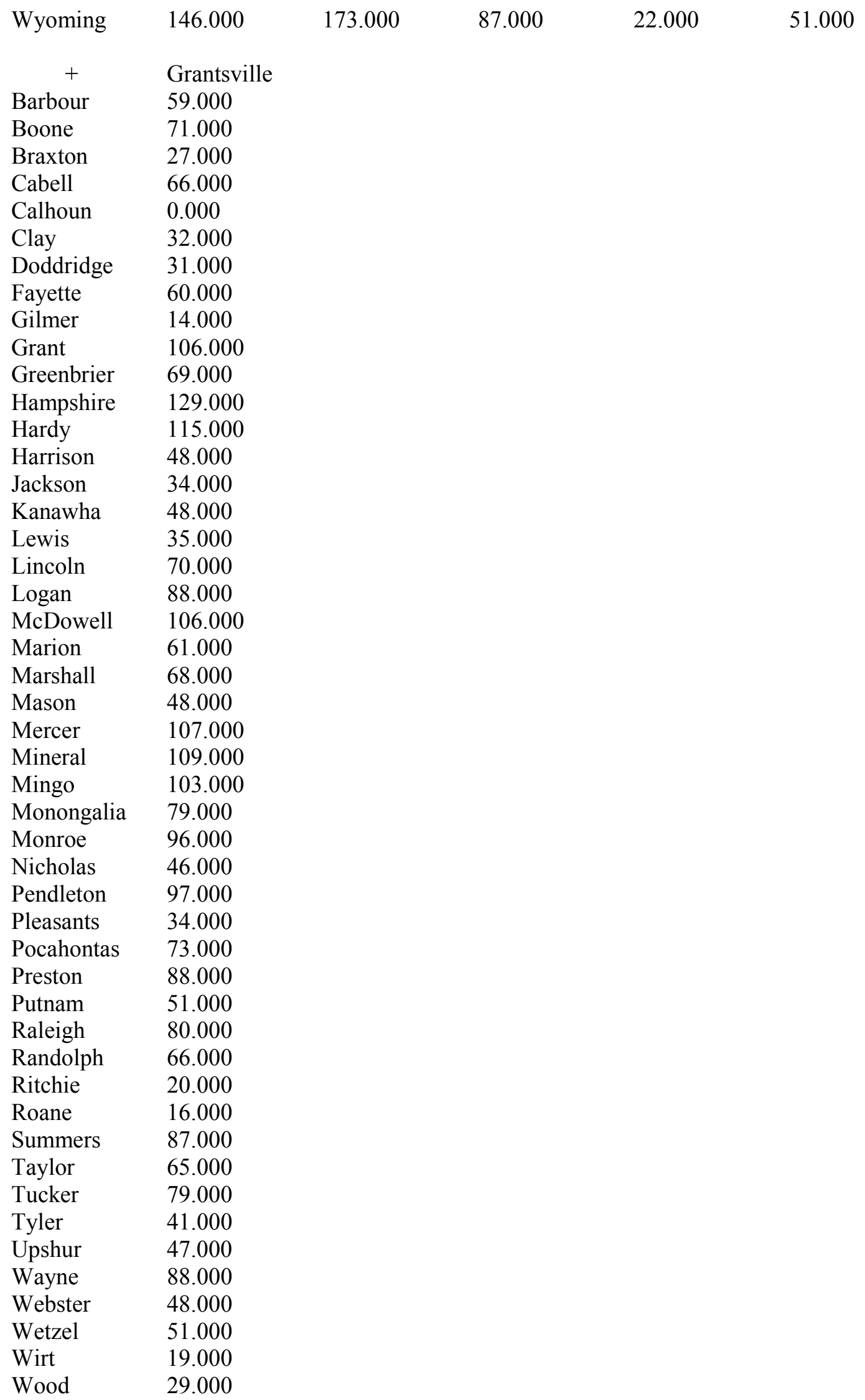


Wyoming $\quad 95.000$

;

$* * * * * * * * * * * * * * * * * * * * * * * * * * * * * * * * * * * * * * * * * * * * * * * * * * * * * * * * * * * * * * * * * * * * * * * * * * * * * * *$

*Assumptions about transportation cost

**********************************************************************************

Scalar TP Truck purchased cost in dollars /140000/;

Scalar TSP Truck salvage value as a percentage of purchased cost $/ 0.20 /$;

Scalar MPG_1 Truck miles per gallon on highways $/ 5 /$;

Scalar MPG_2 Truck miles per gallon on local roads $/ 5 /$;

Scalar MPH_1 Miles per hour on highways $/ 35 /$;

Scalar MPH_2 Miles per hour on local roads $/ 25 /$;

Scalar FPG Fuel price per gallon $/ 3.55 /$;

Scalar DWH Driver's wage per hour including benefits /14/;

Scalar N Economic life of trucks /8/;

Scalar SMH Scheduled machine hours per year $/ 2000 /$;

Scalar IITR Interest insuarance and tax rate /0.20/;

Scalar MR Mainenance and repair rate as a percentage of depreciation /0.90/;

Scalar UT Utilization rate of trucks $/ 0.90 /$;

Parameter TC(I,J) Transportation cost from location i to location $\mathrm{j}$;

$\mathrm{TC}(\mathrm{I}, \mathrm{J})=2 * \mathrm{DIS}(\mathrm{I}, \mathrm{J}) *\left(\mathrm{FPG} / \mathrm{MPG} 1+\mathrm{DWH} / \mathrm{MPH} \_1+((\mathrm{TP}-\mathrm{TP} * \mathrm{TSP}) *(1+\mathrm{MR})+\mathrm{IITR} *\right.$

$\left.\left.\left((\mathrm{TP}-\mathrm{TP} * \mathrm{TSP}) *(\mathrm{~N}+1) / 2+\mathrm{N}^{*} \mathrm{TP} * \mathrm{TSP}\right)\right) / \mathrm{N} / \overline{\mathrm{SMH}} / \mathrm{UT} / \mathrm{MPH} \_1\right)$;

Parameter TL(H) Truck load for handling system $\mathrm{H}$ in tons

/Cable-skidder $\quad 14$

Cableskidder-chip 21

Grapple-skidder $\quad 14$

Grappleskidder-chip 21

Forwarder-loose $\quad 14$

Forwarder-chip 21

Forwarder-bundle $\quad 20 \quad /$;

Parameter TLT(I,J,h) Trucking cost in dollar per ton ;

$\mathrm{TLT}(\mathrm{I}, \mathrm{J}, \mathrm{h})=\mathrm{TC}(\mathrm{I}, \mathrm{J}) / \mathrm{TL}(\mathrm{h})$;

Parameter LTC(H) Transportation cost off highway within counties (\$ per ton.mile);

$\mathrm{LTC}(\mathrm{H})=2 *\left(\mathrm{FPG} / \mathrm{MPG} \_2+\mathrm{DWH} / \mathrm{MPH} 2+\left((\mathrm{TP}-\mathrm{TP} * \mathrm{TSP}) *(1+\mathrm{MR})+\mathrm{IITR}^{*}((\mathrm{TP}-\mathrm{TP} * \mathrm{TSP})\right.\right.$

$\left.*(\mathrm{~N}+1) / 2+\mathrm{N} * \mathrm{TP} * \mathrm{TSP})) / \mathrm{N} / \mathrm{SMH} / \mathrm{UT} / \mathrm{MPH} \_2\right) / \mathrm{TL}(\mathrm{h})$;

Parameter Millcost(R) Cost of mill residue (\$ per green ton)

$\begin{array}{ll}\text { /Bark } & 22.73 \\ \text { chips } & 22.73 \\ \text { sawdust } & 27.27 \\ \text { Planer-shavings } & 18.18 \\ \text { slabs } & 18.18 \\ \text { others } & 9.09 \quad / ;\end{array}$

Parameter Mill_mc(R) Moisture content of mill residue

/Bark $\quad 0.50$

chips $\quad 0.30$

sawdust $\quad 0.30$ 


$\begin{array}{ll}\text { planer-shavings } & 0.20 \\ \text { slabs } & 0.50 \\ \text { others } & 0.50 \quad / \text {; }\end{array}$

Scalar Mill_load Load of mill residue in green tons /21/;

Parameter Milltrancost Cost of delivering mill residue (\$ per ton per mile);

Milltrancost=2*(FPG/MPG_1+DWH/MPH_1+((TP-TP*TSP)*(1+MR)+IITR*((TP-TP*TSP) $\left.\left.\left.*(\mathrm{~N}+1) / 2+\mathrm{N}^{*} \mathrm{TP}{ }^{*} \mathrm{TSP}\right)\right) / \mathrm{N} / \mathrm{SMH} / \mathrm{UT} / \mathrm{MPH} \_1\right) /$ Mill_load;

Scalar TLoss Dry matter loss due to transportation /0.03/;

* Woody biomass-based processing plant assumption

$* * * * * * * * * * * * * * * * * * * * * * * * * * * * * * * * * * * * * * * * * * * * * * * * * * * * * * * * * * * * * * * * * * * * * * * * * * * * * * * *$

Scalar Capacity Plant capacity in terms of daily feedstock requirement in tons /990/;

Parameter FC(SI) Coefficients of linearized local transportation turnover function

$/ 1 \quad 1.583$

$2 \quad 3.322$

34.738

$4 \quad 6.474$

59.156

$6 \quad 11.856$

$7 \quad 14.040$

$8 \quad 15.925$

$9 \quad 18.377 /$;

Parameter B(SI) Right hand side of the constraints for separated variables in linearized function

$11 \quad 1000$

$2 \quad 2000$

32000

$4 \quad 5000$

$5 \quad 10000$

$6 \quad 10000$

$7 \quad 10000$

$8 \quad 10000$

$925000 /$;

Scalar UUP Proportion of woody biomass usable at plant /0.99/;

Parameter MINBV Minimum inventory at plant ;

$\mathrm{MINBV}=0 *$ Capacity ;

\section{Variables \\ $\mathrm{OBF}$ $\mathrm{xh}(\mathrm{I}, \mathrm{H}, \mathrm{M})$ \\ Objective \\ $\mathrm{xt}(\mathrm{I}, \mathrm{J}, \mathrm{H}, \mathrm{M})$ \\ Amounts of logging residues extracted by $\mathrm{H}$ at source $\mathrm{I}$ in month $\mathrm{M}$ \\ $\mathrm{xt} 1(\mathrm{I}, \mathrm{J}, \mathrm{H}, \mathrm{SI})$ \\ Amounts of logging residues extracted by $\mathrm{H}$ transported from I to $\mathrm{J}$ in month $\mathrm{M}$ \\ Annual seperated delivered logging residues from I to $\mathrm{J}$ extracted by $\mathrm{H}$}


$\mathrm{xm}(\mathrm{I}, \mathrm{J}, \mathrm{R}, \mathrm{M}) \quad$ Amounts of mill residue $\mathrm{R}$ delivered from source I to plant $\mathrm{J}$ in month $\mathrm{M}$

$\mathrm{xs}(\mathrm{I}, \mathrm{H}, \mathrm{M}) \quad$ Logging residue extracted by $\mathrm{H}$ stored at source I in month $\mathrm{M}$

$\operatorname{xps}(\mathrm{I}, \mathrm{H}, \mathrm{M}) \quad$ Logging residue extracted by $\mathrm{H}$ going into storage at source $\mathrm{I}$ in month $\mathrm{M}$

$\mathrm{xsn}(\mathrm{I}, \mathrm{H}, \mathrm{M}) \quad$ Logging residue extracted by $\mathrm{H}$ removed from storage at source I in month $\mathrm{M}$

$\operatorname{xss}(\mathrm{J}, \mathrm{M}) \quad$ Woody biomass stored at plant $\mathrm{J}$ in month $\mathrm{M}$

$\operatorname{xpp}(\mathrm{J}, \mathrm{M}) \quad$ Woody biomass processed at plant $\mathrm{J}$ in month $\mathrm{M}$

$\operatorname{Beta}(\mathrm{J}) \quad$ Binary variable for plant location $\mathrm{J}$

Alfa $(\mathrm{I}, \mathrm{H}) \quad$ Binary varialbe for extracting method $\mathrm{H}$ at source $\mathrm{I}$

;

Positive variables $\mathrm{xh}, \mathrm{xt}, \mathrm{xm}, \mathrm{xs}, \mathrm{xps}, \mathrm{xsn}, \mathrm{xss}, \mathrm{xpp}, \mathrm{xt1}$;

Binary variables Beta, Alfa;

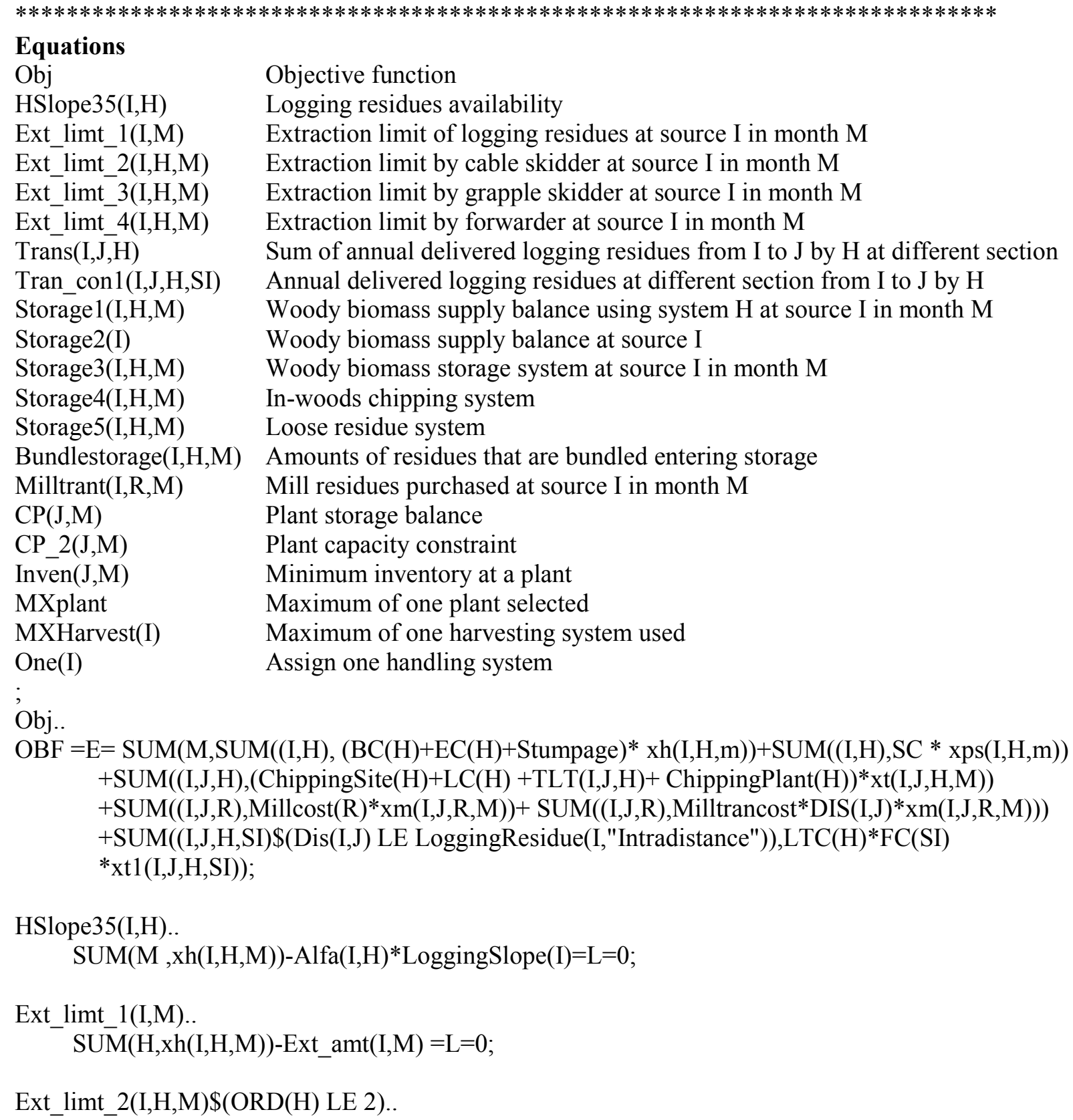

Obj

HSlope35(I,H)

Ext_limt_1(I,M)

Ext_limt_2(I,H,M)

Ext limt 3(I,H,M)

Ext limt 4(I,H,M)

Trans $(\mathrm{I}, \mathrm{J}, \mathrm{H})$

Tran con1(I,J,H,SI)

Storage1(I,H,M)

Storage2(I)

Storage3(I,H,M)

Storage4(I,H,M)

Storage5(I,H,M)

Bundlestorage(I,H,M)

Milltrant(I,R,M)

$\mathrm{CP}(\mathrm{J}, \mathrm{M})$

CP_2(J,M)

Inven $(\mathrm{J}, \mathrm{M})$

MXplant

MXHarvest(I)

One(I)

;

Obj..

$\mathrm{OBF}=\mathrm{E}=\mathrm{SUM}(\mathrm{M}, \mathrm{SUM}((\mathrm{I}, \mathrm{H}),(\mathrm{BC}(\mathrm{H})+\mathrm{EC}(\mathrm{H})+\mathrm{Stumpage}) * \mathrm{xh}(\mathrm{I}, \mathrm{H}, \mathrm{m}))+\mathrm{SUM}((\mathrm{I}, \mathrm{H}), \mathrm{SC} * \mathrm{xps}(\mathrm{I}, \mathrm{H}, \mathrm{m}))$

$+\operatorname{SUM}\left((\mathrm{I}, \mathrm{J}, \mathrm{H}),(\text { ChippingSite }(\mathrm{H})+\mathrm{LC}(\mathrm{H})+\mathrm{TLT}(\mathrm{I}, \mathrm{J}, \mathrm{H})+\text { ChippingPlant }(\mathrm{H}))^{*} \mathrm{xt}(\mathrm{I}, \mathrm{J}, \mathrm{H}, \mathrm{M})\right)$

$+\mathrm{SUM}((\mathrm{I}, \mathrm{J}, \mathrm{R}), \operatorname{Millcost}(\mathrm{R}) * \mathrm{xm}(\mathrm{I}, \mathrm{J}, \mathrm{R}, \mathrm{M}))+\mathrm{SUM}((\mathrm{I}, \mathrm{J}, \mathrm{R}), \mathrm{Milltrancost}$ DIS(I,J)*xm(I,J,R,M $))$

+SUM((I,J,H,SI)\$(Dis(I,J) LE LoggingResidue(I,"Intradistance")),LTC(H)*FC(SI)

*xt1(I,J,H,SI));

HSlope35(I,H)..

$\operatorname{SUM}(\mathrm{M}, \mathrm{xh}(\mathrm{I}, \mathrm{H}, \mathrm{M}))-\mathrm{Alfa}(\mathrm{I}, \mathrm{H}) *$ LoggingSlope $(\mathrm{I})=\mathrm{L}=0$;

Ext_limt_1(I,M)..

$\operatorname{SUM}(\mathrm{H}, \mathrm{xh}(\mathrm{I}, \mathrm{H}, \mathrm{M}))-\mathrm{Ext} \_\operatorname{amt}(\mathrm{I}, \mathrm{M})=\mathrm{L}=0$;

Ext_limt_2(I,H,M $) \$(\mathrm{ORD}(\mathrm{H}) \mathrm{LE} 2)$.

Objective function

Logging residues availability

Extraction limit by grapple skidder at source I in month M

Extraction limit by forwarder at source I in month $\mathrm{M}$

of annual delivered logging residues from $\mathrm{I}$ to $\mathrm{J}$ by $\mathrm{H}$ at different section

Woody biomass supply balance at source I

Woody biomass storage system at source I in month M

system

system

Mill residues purchased at source I in month M

Plant storage balance

Plant capacity constraint

Minimum inventory at a plant

plected

Maximum of one harvesting system used

Assign one handling system 
$\operatorname{xh}(\mathrm{I}, \mathrm{H}, \mathrm{M})-20 * 120 * 1.5 * \mathrm{PD}(\mathrm{H}) / 35.3 * 0.77=\mathrm{L}=0$;

Ext_limt_3(I,H,M $) \$(\mathrm{ORD}(\mathrm{H}) \mathrm{EQ} 3 \mathrm{OR}$ ORD(H) EQ 4).. $\operatorname{xh}(\mathrm{I}, \mathrm{H}, \mathrm{M})-20 * 120 * 1.6 * \mathrm{PD}(\mathrm{H}) / 35.3 * 0.77=\mathrm{L}=0$;

Ext_limt_4(I,H,M $) \$(\mathrm{ORD}(\mathrm{H}) \mathrm{GE} 5)$.. $\mathrm{xh}(\overline{\mathrm{I}}, \mathrm{H}, \mathrm{M})-20 * 120 * 1 * \mathrm{PD}(\mathrm{H}) / 35.3 * 0.77=\mathrm{L}=0$;

$\operatorname{Trans}(\mathrm{I}, \mathrm{J}, \mathrm{H})$.. $\operatorname{SUM}(\mathrm{SI}, \mathrm{xt} 1(\mathrm{I}, \mathrm{J}, \mathrm{H}, \mathrm{SI}))-\mathrm{SUM}((\mathrm{M}), \mathrm{xt}(\mathrm{I}, \mathrm{J}, \mathrm{H}, \mathrm{M}))=\mathrm{E}=0$;

Tran_con1(I,J,H,SI).. $\mathrm{xt} 1(\mathrm{I}, \mathrm{J}, \mathrm{H}, \mathrm{SI})=\mathrm{L}=\mathrm{B}(\mathrm{SI})$;

Storage1(I,H,M).. $\mathrm{xh}(\mathrm{I}, \mathrm{H}, \mathrm{M})+\mathrm{UPS} * \mathrm{xs}(\mathrm{I}, \mathrm{H}, \mathrm{M}-1)-\mathrm{SUM}(\mathrm{J}, \mathrm{xt}(\mathrm{I}, \mathrm{J}, \mathrm{H}, \mathrm{M}))-\mathrm{xs}(\mathrm{I}, \mathrm{H}, \mathrm{M})=\mathrm{G}=0$;

Storage2(I).. SUM((H,M),xh(I,H,M))-SUM((J,H,M),xt(I,J,H,M))-(1-UPS)*SUM((H,M),xs(I,H,M)) =E=0;

Storage3(I,H,M). $x h(I, H, M)-x p s(I, H, M)+x \operatorname{xn}(I, H, M)-S U M((J), x t(I, J, H, M))=E=0 ;$

Storage4(I,H,M)\$(ORD(H) EQ 2 or ORD(H) EQ 4 or ORD(H) EQ 6).. $\operatorname{xps}(\mathrm{I}, \mathrm{H}, \mathrm{M})=\mathrm{E}=0$;

Storage5(I,H,M)\$ $(\mathrm{ORD}(\mathrm{H}) \mathrm{EQ} 1$ or $\mathrm{ORD}(\mathrm{H})$ EQ 3 or $\mathrm{ORD}(\mathrm{H})$ EQ 5).. $\operatorname{xps}(\mathrm{I}, \mathrm{H}, \mathrm{M})-\mathrm{xh}(\mathrm{I}, \mathrm{H}, \mathrm{M})=\mathrm{L}=0$;

Bundlestorage(I,H,M) \$ (ORD(H) EQ 7).. $\operatorname{xps}(\mathrm{I}, \mathrm{H}, \mathrm{M})-\mathrm{xh}(\mathrm{I}, \mathrm{H}, \mathrm{M})=\mathrm{E}=0$;

Milltrant(I,R,M)..

$\operatorname{SUM}(\mathrm{J}, \mathrm{xm}(\mathrm{I}, \mathrm{J}, \mathrm{R}, \mathrm{M}))-\operatorname{MillProp}(\mathrm{I}) * 4 * \operatorname{MillResidue}(\mathrm{I}, \mathrm{R})=\mathrm{L}=0$;

$\mathrm{CP}(\mathrm{J}, \mathrm{M})$.

SUM((I,R),(1-Mill_mc(R))*xm(I,J,R,M))+SUM((I,H),(1-Logres_mc)*(1-TLoss)*xt(I,J,H,M)) $+\mathrm{UUP}^{*} \mathrm{xss}(\mathrm{J}, \mathrm{M}-\overline{1})-\mathrm{xss}(\mathrm{J}, \mathrm{M})-\mathrm{xpp}(\mathrm{J}, \mathrm{M})=\mathrm{E}=0$;

CP_2(J,M).. $\mathrm{xpp}(\mathrm{J}, \mathrm{M})-30 *$ Capacity*Beta $(\mathrm{J})=\mathrm{E}=0$;

Inven $(\mathrm{J}, \mathrm{M})$. $\operatorname{xss}(\mathrm{J}, \mathrm{M})-\mathrm{MINBV} * \operatorname{Beta}(\mathrm{J})=\mathrm{G}=0$;

MXplant.. $\operatorname{SUM}(J, \operatorname{Beta}(J))=E=1$;

MXHarvest(I).. $\operatorname{SUM}(\mathrm{H}, \mathrm{Alfa}(\mathrm{I}, \mathrm{H}))=\mathrm{E}=1$; 
One(I)..

Alfa(I,"Cable-skidder") $=\mathrm{E}=1$;

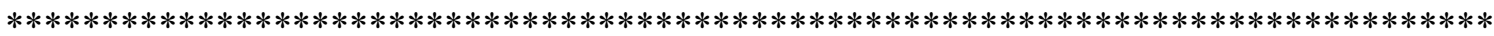

Model Bioplant /all/;

Solve Bioplant minimizing OBF using MIP;

Option solprint $=$ off;

$* * * * * * * * * * * * * * * * * * * * * * * * * * * * * * * * * * * * * * * * * * * * * * * * * * * * * * * * * * * * * * * * * * * * * * * * * * * * * * * * *$

*Results

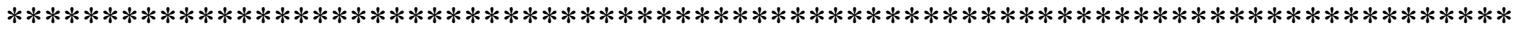

*Unit delivered cost of woody biomass (logging residue and mill residue jointly)

$* * * * * * * * * * * * * * * * * * * * * * * * * * * * * * * * * * * * * * * * * * * * * * * * * * * * * * * * * * * * * * * * * * * * * * * * * * * * * * * *$

Parameter unitcost_dryton, unitcost_metric;

unitcost dryton=OBF.1/(SUM((I,J,R,m),(1-Mill mc(R))*xm.1(I,J,R,M))+SUM((I,J,H,m),(1-

logres_mc)*xt.1(I,J,H,M)));

unitcost_metric=1.1*OBF.1/(SUM((I,J,R,m),(1-Mill_mc(R))*xm.1(I,J,R,M))+SUM((I,J,H,m),(1-

logres_mc)*xt.1(I,J,H,M)));

Display unitcost_dryton, unitcost_metric;

$* * * * * * * * * * * * * * * * * * * * * * * * * * * * * * * * * * * * * * * * * * * * * * * * * * * * * * * * * * * * * * * * * * * * * * * * * * * * * * *$

$*$ Unit delivered cost of logging residue/mill residue

**********************************************************************************

Parameter log_cost, mill_cost, log_cost_metric, mill_cost_metric;

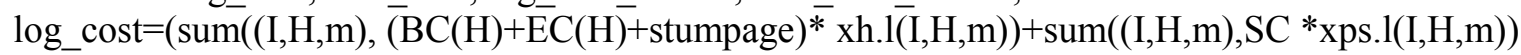
$+\operatorname{sum}\left((\mathrm{I}, \mathrm{J}, \mathrm{H}, \mathrm{m}),(\mathrm{LC}(\mathrm{H})+\mathrm{TLT}(\mathrm{I}, \mathrm{J}, \mathrm{H}))^{*} \mathrm{xt} .1(\mathrm{I}, \mathrm{J}, \mathrm{H}, \mathrm{M})\right)+\operatorname{sum}((\mathrm{I}, \mathrm{J}, \mathrm{H}, \mathrm{SI}) \$(\mathrm{Dis}(\mathrm{I}, \mathrm{J}) \mathrm{LE}$

LoggingResidue(I,"Intradistance")),LTC(H)*FC(SI)*xt1.1(I,J,H,SI))

$+\operatorname{sum}\left((\mathrm{I}, \mathrm{J}, \mathrm{H}, \mathrm{m}),(\text { ChippingSite }(\mathrm{H})+\text { ChippingPlant }(\mathrm{H}))^{*}\right.$ xt.l(I,J,H,M $\left.)\right)$

/SUM((I,J,H,m),(1-logres_mc)*xt.l(I,J,H,M));

mill_cost $=(\operatorname{sum}((\mathrm{I}, \mathrm{J}, \mathrm{R}, \mathrm{m}), \operatorname{Milltrancost} * \operatorname{Dis}(\mathrm{I}, \mathrm{J}) * x \mathrm{xm} .1(\mathrm{I}, \mathrm{J}, \mathrm{R}, \mathrm{M}))+\operatorname{sum}((\mathrm{I}, \mathrm{J}, \mathrm{R}, \mathrm{m}), \operatorname{Millcost}(\mathrm{R})$

*xm.1(I,J,R,M)))/SUM((I,J,R,m),(1-Mill_mc(R))*xm.1(I,J,R,M ));

log_cost_metric=log_cost*1.10;

mill_cost_metric=mill_cost*1.10;

Display log_cost, mill_cost,log_cost_metric, mill_cost_metric;

$* * * * * * * * * * * * * * * * * * * * * * * * * * * * * * * * * * * * * * * * * * * * * * * * * * * * * * * * * * * * * * * * * * * * * * * * * * * * * * *$

*Average hauling distance for logging residue and mill residue

*********************************************************************************

Parameters avg_dis_log, avg_dis_mill;

avg_dis_log=sum $((\overline{\mathrm{I}}, \mathrm{J}, \mathrm{H}, \mathrm{m}), \mathrm{Dis}(\overline{\mathrm{I}}, \mathrm{J}) * \mathrm{xt} .1(\mathrm{I}, \mathrm{J}, \mathrm{H}, \mathrm{M})) / \operatorname{sum}((\mathrm{I}, \mathrm{J}, \mathrm{H}, \mathrm{m}), \mathrm{xt} .1(\mathrm{I}, \mathrm{J}, \mathrm{H}, \mathrm{M}))$;

avg_dis_mill=sum((I,J),Dis(I,J)*sum((R,m),xm.l(I,J,R,M)))/sum((I,J,R,m),xm.1(I,J,R,M));

Display avg_dis_log, avg_dis_mill; 


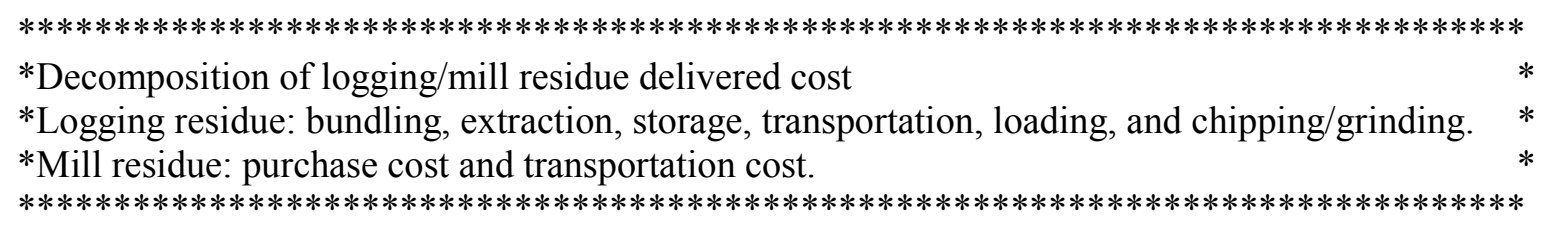

Parameters log_c1_metric, $\log \_$c2_metric, $\log$ c3 3 metric, $\log$ c4 4 metric, log_c5_metric, $\log$ _c6_metric, log_c7_metric, mill_c1_metric, mill_c2_metric;

log_c1_metric=1.10*sum((I,H,m), BC(H)*xh.1(I,H,m))/SUM((I,J,H,m),(1-logres_mc) *xt.1(I,J,H,M));

log_c2_metric=1.10*sum((I,H,m), EC(H)*xh.1(I,H,m))/SUM((I,J,H,m),(1-logres_mc)*xt.1(I,J,H,M));

log_c3_metric=1.10*sum((I,H,m),SC *xps.l(I,H,m))/SUM((I,J,H,m),(1-logres_mc)* xt.1(I,J,H,M));

log_c4_metric=1.10*(sum((I,J,H,m),TLT(I,J,H)*xt.1(I,J,H,M))+SUM((I,J,H,SI)\$(Dis(I,J) LE

LoggingResidue(I,"Intradistance")),LTC(H)*FC(SI)*xt1.1(I,J,H,SI)))

/SUM((I,J,H,m),(1-logres_mc)* xt.1(I,J,H,M));

log_c5_metric=1.10*sum((I,J,H,m),LC(H)*xt.1(I,J,H,M))/SUM((I,J,H,m),(1-logres_mc)*xt.1(I,J,H,M));

log_c6_metric $=1.10 * \operatorname{sum}((\mathrm{I}, \mathrm{J}, \mathrm{H}, \mathrm{m}),(\mathrm{ChippingSite}(\mathrm{H})+\mathrm{ChippingPlant}(\mathrm{H})) *$ xt.1(I,J,H,M $))$

/SUM((I,J,H,m),(1-logres_mc)*xt.1(I,J,H,M));

log_c7_metric=1.10*sum((I,H,m),(stumpage)* xh.1(I,H,M))/SUM $((\mathrm{I}, \mathrm{J}, \mathrm{H}, \mathrm{m}),(1-$ logres_mc $)$

* xt.1(I,J,H,M));

mill_c1_metric=1.10*sum((I,J,R,m),Millcost(R)*xm.1(I,J,R,M))/SUM((I,J,R,m),(1-Mill_mc(R))

*xm.1(I,J,R,M));

mill_c2_metric $=1.10 * \operatorname{sum}((\mathrm{I}, \mathrm{J}, \mathrm{R}, \mathrm{m}), \operatorname{Milltrancost} * \operatorname{Dis}(\mathrm{I}, \mathrm{J}) * \mathrm{xm} .1(\mathrm{I}, \mathrm{J}, \mathrm{R}, \mathrm{M}))$

/SUM((I,J,R,m),(1-Mill_mc(R)) *xm.1(I,J,R,M));

Display log_c1_metric, $\log$ c2 2 metric, $\log \_$c3_metric, $\log \_$c4_metric, log_c5_metric, log_c6_metric, log_c7_metric, mill_c1_metric, mill_c2_metric; 


\section{APPENDIX II: ECONOMIC ANALYSIS MODEL FOR A WOOD BIOMASS PLANT}

\section{II.1 System requirement}

To run the economic analysis model, the following requirements must be met:

- The GAMS system must be installed in a computer. For more detailed instruction, please go to http://www.gams.com/default.htm.

- A GAMS/Cplex license file must be presented.

\section{II.2 Source code}

\section{Sontext}

This program is used to determine the best location for a woody-biomass based ethanol facility given the feedstock requirement per day. The objective function is to maximize the Net Present Value of the facility.

Programmed by Jinzhuo Wu

Division of Forestry

West Virginia University

June 26, 2009

\$offtext

\section{\$OFFSYMLIST OFFSYMXREF}

OPTION LIMCOL $=0$;

OPTION LIMROW $=0$;

OPTION SOLSLACK $=1$;

OPTION ITERLIM=5000000;

OPTION RESLIM=1000000;

\section{Sets}

I Woody biomass supply locations

/Barbour,Boone, Braxton, Cabell, Calhoun, Clay, Doddridge, Fayette, Gilmer, Grant, Greenbrier, Hampshire, Hardy, Harrison, Jackson, Kanawha, Lewis, Lincoln, Logan, Marion, Marshall, Mcdowell, Mason, Mercer, Mineral, Mingo, Monongalia, Monroe, Nicholas, Pleasants, Pendleton, Pocahontas, Preston, Putnam, Raleigh, Randolph, Ritchie, Roane, Summers, Taylor, Tucker, Tyler, Upshur, Wayne, Webster, Wetzel, Wirt, Wood, Wyoming, V_Alleghany, V_Buchanan, V_Bath, V_Bland, V_Craig, V_Dickenson, V_Giles, V_Highland, V_Russell, V_Smyth, V_Tazewell, V_Wise, K_Boyd, K_Carter, K_Elliott, K_Floyd, K_Greenup, K_Johnson, K_Lawrence, K_Martin, K_Magoffin, K_Morgan, $\bar{K} \_$Pike, O_Athens, O_Belmont, O_Gallia, O_Jackson, O_Lawrence, O_Meigs, O_Monroe, O_Morgan, O_Noble, O_Scioto, O_Vinton, O_Washington,

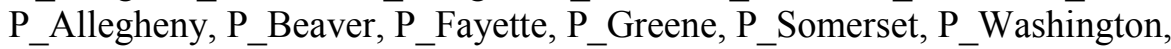
P_Westmoreland, M_Garrett, M_Allegany/

J Potential locations for the woody biomass-based ethanol plant /Beaver_Raleigh, Belington, Bluefield, Buckhannon, Holden, Kenna, Millwood, Morgantown, Oak_Hill_Fayette, Point_Pleasant, Williamson/

M Months of the production year

/Jan, Feb, Mar, Apr, May, Jun, Jul, Aug, Sep, Oct, Nov, Dec/

$\mathrm{H} \quad$ Logging residue handling systems 
/Cable-skidder, Cableskidder-chip, Grapple-skidder, Grappleskidder-chip/

LogStat Logging residues related statistics for each county

/Quantities, SlopeLess35, IntraDistance/

G Products

/Ethanol, Electricity/

Process_area Woody biomass to ethanol process area

/Feed_handling, Pretreatment, SSCF, Cellulase_production, Distillation, WWT, Storage, Boiler_turbogen, Utilities/

Project_year_Index of the project year

$/ 1 * 20 /$

SI Separated line segment index for nonlinear programming $/ 1 * 9 /$

Parameter MC(H) Hourly cost of extraction machine (\$ per PMH)

/Cable-skidder $\quad 81.34$

Cableskidder-chip $\quad 81.34$

Grapple-skidder $\quad 102.72$

Grappleskidder-chip $\quad 102.72 /$;

Parameter $\operatorname{AED}(\mathrm{H}) \quad$ Average extraction distance (feet);

$\operatorname{AED}(\mathrm{H})=984$;

Parameter PL(H) Average payload size (cubic foot)

/Cable-skidder $\quad 106$

Cableskidder-chip $\quad 106$

Grapple-skidder $\quad 107.87$

Grappleskidder-chip $\quad 107.87$;

Scalar BZ Bunch size (cubic foot) /54/;

Parameter $\mathrm{PD}(\mathrm{H}) \quad$ Productivity of extraction machine (cubic foot per hour);

$\mathrm{PD}(\mathrm{H}) \$(\mathrm{ORD}(\mathrm{H}) \mathrm{LE} 2)=144.22-0.00001 * \mathrm{AED}(\mathrm{H}) * * 2+1.60 * \mathrm{PL}(\mathrm{H})-1087.54 / \mathrm{PL}(\mathrm{H})$

$-0.0003 * \mathrm{PL}(\mathrm{H}) * * 2+0.14 * \mathrm{BZ}+7.35 / \mathrm{BZ}-0.0008 * \mathrm{BZ} * \mathrm{BZ}$

$\mathrm{PD}(\mathrm{H}) \$(\mathrm{ORD}(\mathrm{H})$ EQ 3 or $\mathrm{ORD}(\mathrm{H})$ EQ 4$)=505.88-0.00004 * \mathrm{AED}(\mathrm{H}) * * 2+$

$0.005 * \mathrm{PL}(\mathrm{H}) * * 2$;

Parameter EC(H) Extraction cost for each system (\$ per green ton);

$\mathrm{EC}(\mathrm{H})=\mathrm{MC}(\mathrm{H}) /(\mathrm{PD}(\mathrm{H}) / 35.3 * 0.77)$;

Scalar Loader_cost Hourly cost of loader (\$ per hour) /85.96/;

Scalar Logres_D Small end diameter of slash $/ 5 /$;

Scalar NL Number of small logs or slash grappled per turn $/ 5 /$;

Parameter $\mathrm{LC}(\mathrm{H}) \quad$ Average loading cost corresponding to harvesting system (\$ per ton); 


$$
\mathrm{LC}(\mathrm{H})=\text { Loader_cost } /((-10.14+1.23 * \text { Logres_D+1.7058*NL)*162/ 35.3*0.77); }
$$

Parameter Cost_chipper(H) Hourly chipping cost (\$)

$\begin{array}{ll}\text { /Cable-skidder } & 212.27 \\ \text { Cableskidder-chip } & 185.62 \\ \text { Grapple-skidder } & 212.27 \\ \text { Grappleskidder-chip } & 185.62 / \text {; }\end{array}$

Parameter Productivity_chipper(H) Hourly chipping productivity (green tons)

$\begin{array}{ll}\text { /Cable-skidder } & 91 \\ \text { Cableskidder-chip } & 30 \\ \text { Grapple-skidder } & 91 \\ \text { Grappleskidder-chip } & 30 / \text {; }\end{array}$

Parameter ChippingSite $(\mathrm{H})$ Chipping cost on forest landings (\$ per ton); ChippingSite $(\mathrm{H}) \$(\mathrm{ORD}(\mathrm{H})$ EQ 1 OR ORD $(\mathrm{H})$ EQ 3) $=0$;

ChippingSite $(\mathrm{H}) \$(\mathrm{ORD}(\mathrm{H}) \mathrm{EQ} 2 \mathrm{OR}$ ORD $(\mathrm{H})$ EQ 4)

$=$ Cost_chipper $(\mathrm{H}) / \operatorname{Productivity\_ chipper}(\mathrm{H})$;

Parameter ChippingPlant $(\mathrm{H}) \quad$ Chipping cost at the plant (\$ per green ton);

ChippingPlant $(\mathrm{H}) \$(\mathrm{ORD}(\mathrm{H})$ EQ 2 OR ORD $(\mathrm{H})$ EQ 4) $=0$;

ChippingPlant $(\mathrm{H}) \$(\mathrm{ORD}(\mathrm{H})$ EQ 1 OR ORD(H) EQ 3)

$=$ Cost_chipper $(\mathrm{H}) / \operatorname{Productivity}$ _chipper $(\mathrm{H})$;

\begin{tabular}{|c|c|c|c|}
\hline \multicolumn{4}{|c|}{ 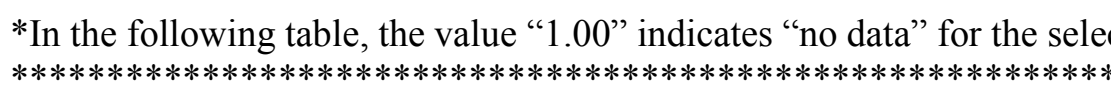 } \\
\hline \multicolumn{4}{|c|}{ Table LoggingResidue(I,LogStat) Logging residues statistics by county } \\
\hline & Quantities & SlopeLess 35 & IntraDistance \\
\hline Barbour & 23885 & 0.79 & 13 \\
\hline Boone & 52539 & 0.37 & 16 \\
\hline Braxton & 85558 & 0.67 & 15 \\
\hline Cabell & 19352 & 0.89 & 12 \\
\hline Calhoun & 38323 & 0.63 & 13 \\
\hline Clay & 61457 & 0.66 & 11 \\
\hline Doddridge & 49434 & 0.65 & 12 \\
\hline Fayette & 108269 & 0.63 & 18 \\
\hline Gilmer & 41961 & 0.71 & 15 \\
\hline Grant & 25182 & 0.74 & 15 \\
\hline Greenbrier & 70650 & 0.76 & 20 \\
\hline Hampshire & 29328 & 0.92 & 15 \\
\hline Hardy & 19834 & 0.71 & 15 \\
\hline Harrison & 43089 & 0.76 & 13 \\
\hline Jackson & 26038 & 0.87 & 15 \\
\hline Kanawha & 158324 & 0.63 & 24 \\
\hline Lincoln & 18459 & 0.72 & 17 \\
\hline Logan & 16380 & 0.24 & 16 \\
\hline Lewis & 40551 & 0.60 & 14 \\
\hline Marion & 42215 & 0.90 & 14 \\
\hline Marshall & 31743 & 0.66 & 10 \\
\hline McDowell & 70707 & 0.40 & 17 \\
\hline
\end{tabular}




\begin{tabular}{|c|c|c|c|}
\hline Mason & 18170 & 0.87 & 17 \\
\hline Mercer & 44234 & 0.69 & 14 \\
\hline Mineral & 12671 & 0.64 & 14 \\
\hline Mingo & 69417 & 0.31 & 17 \\
\hline Monongalia & 28661 & 0.82 & 16 \\
\hline Monroe & 42422 & 0.92 & 19 \\
\hline Nicholas & 87436 & 0.74 & 21 \\
\hline Pendleton & 28134 & 0.53 & 18 \\
\hline Pleasants & 23575 & 0.71 & 8 \\
\hline Pocahontas & 29431 & 0.71 & 26 \\
\hline Preston & 90343 & 0.85 & 15 \\
\hline Putnam & 23471 & 0.80 & 15 \\
\hline Raleigh & 80051 & 0.58 & 17 \\
\hline Randolph & 113787 & 0.68 & 25 \\
\hline Ritchie & 63995 & 0.85 & 13 \\
\hline Roane & 44518 & 0.76 & 15 \\
\hline Summers & 12775 & 0.59 & 12 \\
\hline Taylor & 23885 & 1.00 & 9 \\
\hline Tucker & 36716 & 0.77 & 15 \\
\hline Tyler & 23575 & 0.86 & 10 \\
\hline Upshur & 65941 & 0.84 & 14 \\
\hline Wayne & 22491 & 0.73 & 19 \\
\hline Webster & 88773 & 0.53 & 16 \\
\hline Wetzel & 47065 & 0.61 & 13 \\
\hline Wirt & 39527 & 0.90 & 9 \\
\hline Wood & 30324 & 1.00 & 14 \\
\hline Wyoming & 30324 & 0.43 & 15 \\
\hline V Alleghany & 35539 & 1.00 & 12 \\
\hline V_Buchanan & 6620 & 1.00 & 16 \\
\hline V_Bath & 22848 & 1.00 & 12 \\
\hline $\mathrm{V}_{-}$Bland & 16778 & 1.00 & 12 \\
\hline V_Craig & 6620 & 1.00 & 14 \\
\hline $\mathrm{V}^{-}$Dickenson & 96078 & 1.00 & 12 \\
\hline $\mathrm{V}^{-}$Giles & 23087 & 1.00 & 14 \\
\hline V_Highland & 28967 & 1.00 & 11 \\
\hline V_Russell & 10564 & 1.00 & 17 \\
\hline V_Smyth & 17758 & 1.00 & 16 \\
\hline V_Tazewell & 8150 & 1.00 & 18 \\
\hline V_Wise & 19502 & 1.00 & 15 \\
\hline K_Boyd & 6716 & 1.00 & 8 \\
\hline $\mathrm{K}_{-}^{-}$Carter & 34177 & 1.00 & 14 \\
\hline $\mathrm{K}$ Elliott & 13097 & 1.00 & 10 \\
\hline $\mathrm{K}_{-}^{-}$Floyd & 21391 & 1.00 & 16 \\
\hline K_Greenup & 26123 & 1.00 & 12 \\
\hline K_Johnson & 12524 & 1.00 & 12 \\
\hline $\mathrm{K}-$ Lawrence & 9010 & 1.00 & 13 \\
\hline $\mathrm{K}_{-}^{-}$Martin & 16419 & 1.00 & 10 \\
\hline K_Magoffin & 8939 & 1.00 & 14 \\
\hline K_Morgan & 31118 & 1.00 & 14 \\
\hline $\mathrm{K}_{-}$Pike & 64602 & 1.00 & 19 \\
\hline $\mathrm{O}_{-}^{-}$Athens & 25694 & 1.00 & 15 \\
\hline
\end{tabular}




\begin{tabular}{llll} 
O_Belmont & 10355 & 1.00 & 17 \\
O_Gallia & 12893 & 1.00 & 16 \\
O_Jackson & 93231 & 1.00 & 14 \\
O_Lawrence & 6858 & 1.00 & 15 \\
O_Meigs & 37114 & 1.00 & 15 \\
O_Monroe & 0 & 1.00 & 14 \\
O_Morgan & 25021 & 1.00 & 14 \\
O_Noble & 7565 & 1.00 & 15 \\
O_Scioto & 82788 & 1.00 & 17 \\
O_Vinton & 95245 & 1.00 & 15 \\
O_Washington & 16779 & 1.00 & 22 \\
P_Allegheny & 10226 & 1.00 & 16 \\
P_Beaver & 2051 & 1.00 & 15 \\
P_Fayette & 54443 & 1.00 & 18 \\
P_Greene & 23573 & 1.00 & 18 \\
P_Somerset & 92975 & 1.00 & 24 \\
P_Washington & 15454 & 1.00 & 22 \\
P-Westmoreland & 43896 & 1.00 & 24 \\
M_Allegany & 63394 & 1.00 & 16 \\
M_Garrett & 110094 & 1.00 & 21 \\
\hline
\end{tabular}

Scalar BP Proportion of woody biomass that can be economically harvested /0.65/;

Parameter Loggingavai(I) Logging residue in tons for each supply location; Loggingavai $(\mathrm{I})=$ LoggingResidue(I,"Quantities")*BP ;

Parameter LoggingSlope(I) Logging residue at sites with less than 35 percent slope; *WV counties LoggingSlope(I)\$ (ORD(I) LE 49)=Loggingavai(I)*LoggingResidue(I,"SlopeLess35"); *Non WV counties LoggingSlope(I)\$ (ORD(I) GE 50)=0.65*LoggingResidue(I,"Quantities");

Scalar WC Moisture content /0.43/;

Parameter ExtProp(M) Extracted proportion as a percentage of the whole year

$\begin{array}{ll}\text { Jan } & 0.083 \\ \text { Feb } & 0.083 \\ \text { Mar } & 0.083 \\ \text { Apr } & 0.083 \\ \text { May } & 0.075 \\ \text { Jun } & 0.075 \\ \text { Jul } & 0.075 \\ \text { Aug } & 0.075 \\ \text { Sep } & 0.092 \\ \text { Oct } & 0.092 \\ \text { Nov } & 0.092 \\ \text { Dec } & 0.092 / \text {; }\end{array}$

Parameter Ext_amt(I,H,M) Extraction limt per month by county in green tons; Ext_amt $(\bar{I}, \mathrm{H}, \mathrm{M})=$ LoggingSlope(I)* ExtProp(M); 
$* * * * * * * * * * * * * * * * * * * * * * * * * * * * * * * * * * * * * * * * * * * * * * * * * * * * * * * * * * * * * * * * * * * * * * * * * * * * * * * * * *$

* Proportion of available woody biomass on site

$* * * * * * * * * * * * * * * * * * * * * * * * * * * * * * * * * * * * * * * * * * * * * * * * * * * * * * * * * * * * * * * * * * * * * * * * * * * * * * *$

Scalar UPS Usable proportion of logging residues at supply locations /0.95/;

Scalar Stumpage Stumpage cost of logging residues in dollar per ton /0.91/;

Scalar SC Storage cost for logging residues in the field in dollar per ton /0.00/;

Parameter MillResidue(I) Amounts of mill residues by county in green tons

\begin{tabular}{|c|c|}
\hline /Barbour & 19200 \\
\hline Boone & 0 \\
\hline Braxton & 39360 \\
\hline Cabell & 0 \\
\hline Calhoun & 0 \\
\hline Clay & 19584 \\
\hline Doddridge & 12720 \\
\hline Fayette & 18000 \\
\hline Gilmer & 48 \\
\hline Grant & 3456 \\
\hline Greenbrier & 65616 \\
\hline Hampshire & 0 \\
\hline Hardy & 2688 \\
\hline Harrison & 0 \\
\hline Jackson & 2880 \\
\hline Kanawha & 43440 \\
\hline Lewis & 576 \\
\hline Lincoln & 0 \\
\hline Logan & 0 \\
\hline Marion & 0 \\
\hline Marshall & 0 \\
\hline Mcdowell & 0 \\
\hline Mason & 0 \\
\hline Mercer & 960 \\
\hline Mineral & 4800 \\
\hline Mingo & 57989 \\
\hline Monongalia & 48 \\
\hline Monroe & 8160 \\
\hline Nicholas & 153264 \\
\hline Pleasants & 0 \\
\hline Pendleton & 19200 \\
\hline Pocahontas & 76704 \\
\hline Preston & 101280 \\
\hline Putnam & 0 \\
\hline Raleigh & 40800 \\
\hline Randolph & 213104 \\
\hline Ritchie & 3000 \\
\hline Roane & 480 \\
\hline Summers & 9600 \\
\hline Taylor & 720 \\
\hline Tucker & 0 \\
\hline
\end{tabular}




$\begin{array}{ll}\text { Tyler } & 0 \\ \text { Upshur } & 55200 \\ \text { Wayne } & 0 \\ \text { Webster } & 14256 \\ \text { Wetzel } & 7680 \\ \text { Wirt } & 0 \\ \text { Wood } & 145 \\ \text { Wyoming } & 14 \\ \text { V_Alleghany } & 48757 \\ \text { V_Buchanan } & 21102 \\ \text { V_Bath } & 0 \\ \text { V_Bland } & 0 \\ \text { V_Craig } & 0 \\ \text { V_Dickenson } & 0 \\ \text { V_Giles } & 0 \\ \text { V_Highland } & 0 \\ \text { V_Russell } & 0 \\ \text { V_Smyth } & 0 \\ \text { V_Tazewell } & 0 \\ \text { V_Wise } & 0 \\ \text { K_Boyd } & 0 \\ \text { K_Carter } & 49167 \\ \text { K_Elliott } & 0 \\ \text { K_Floyd } & 27924 \\ \text { K_Greenup } & 4131 \\ \text { K_Johnson } & 0 \\ \text { K_Lawrence } & 0 \\ \text { K_Martin } & 0 \\ \text { K_Magoffin } & 293 \\ \text { K_Morgan } & 65488 \\ \text { K_Pike } & 177548 \\ \text { O_Athens } & 11514 \\ \text { O_Belmont } & 87840 \\ \text { O_Gallia } & 23363 \\ \text { O_Jackson } & 41977 \\ \text { O_Lawrence } & 0 \\ \text { O_Meigs } & 66733 \\ \text { O_Monroe } & 0 \\ \text { O_Morgan } & 0 \\ \text { O_Noble } & 0 \\ \text { O_Scioto } & 44388 \\ \text { O_Vinton } & 286279 \\ \text { O_Washington } & 125023 \\ \text { P_Allegheny } & 8567 \\ \text { P_Beaver } & 0 \\ \text { P_Fayette } & 104890 \\ \text { P_Greene } & 3900 \\ \text { P_Somerset } & 67440 \\ \text { P_Washington } & 1348 \\ \text { P_Westmoreland } & 55750 \\ \text { M_Garrett } & 0 \\ \text { _- } & \end{array}$


M_Allegany $353183 /$;

Parameter MillProp(I) Proportion of mill residues available in each county; $\operatorname{MillProp}(\mathrm{I})=0.4$;

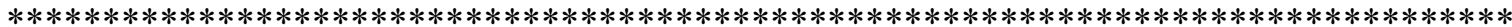

*Get the distance between any supply location and potential plant location from computer

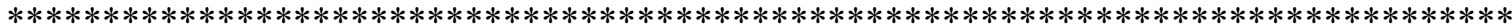

\$CALL GDXXRW.EXE C:\GAMS_Dis \distance.xls par=dis rng=D4:O97

Parameter dis(i,j);

\$GDXIN distance.gdx

\$Load dis

\$GDXIN

Display dis;

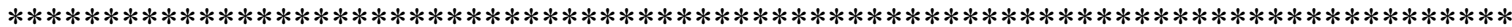

*Assumptions about transportation cost

$* * * * * * * * * * * * * * * * * * * * * * * * * * * * * * * * * * * * * * * * * * * * * * * * * * * * * * * * * * * * * * * * * * * * * * * * * * * * * * * * *$

Scalar TP Truck purchased cost in dollars /140000/;

Scalar TSP Truck salvage value as a percentage of purchased cost $/ 0.20 /$;

Scalar MPG_1 Truck miles per gallon on highways $/ 5 /$;

Scalar MPG_2 Truck miles per gallon on local roads $/ 5 /$;

Scalar MPH_1 Miles per hour on highways $/ 35 /$;

Scalar MPH_2 Miles per hour on local roads $/ 25 /$;

Scalar FPG Fuel price per gallon $/ 3.55 /$;

Scalar DWH Driver's wage per hour including benefits /14/;

Scalar N Economic life of trucks /8/;

Scalar SMH Scheduled machine hours per year $/ 2000 /$;

Scalar IITR Interest insurance and tax rate $/ 0.20 /$;

Scalar MR Maintenance and repair rate as a percentage of depreciation /0.90/;

Scalar UT Utilization rate of trucks /0.90/;

Parameter TC(I,J) Transportation rate from location i to location $\mathrm{j}$;

$\mathrm{TC}(\mathrm{I}, \mathrm{J})=2 * \operatorname{Dis}(\mathrm{I}, \mathrm{J}) *\left(\mathrm{FPG} / \mathrm{MPG} \_1+\mathrm{DWH} / \mathrm{MPH} \_1+((\mathrm{TP}-\mathrm{TP} * \mathrm{TSP}) *(1+\mathrm{MR})+\mathrm{IITR} *((\mathrm{TP}-\mathrm{TP} * \mathrm{TSP})\right.$

$\left.*(\mathrm{~N}+1) / 2+\mathrm{N} * \mathrm{TP} * \mathrm{TSP})) / \mathrm{N} / \mathrm{SMH} / \mathrm{UT} / \mathrm{MPH} \_1\right)$;

*********************************************************************************

*Truck and trailer loads for loose slash and chips $\quad *$

$* * * * * * * * * * * * * * * * * * * * * * * * * * * * * * * * * * * * * * * * * * * * * * * * * * * * * * * * * * * * * * * * * * * * * * * * * * * * * * *$

Parameter TL(H) Truck load for harvesting system $\mathrm{H}$ in tons

/Cable-skidder 14

Cableskidder-chip 21

Grapple-skidder $\quad 14$

Grappleskidder-chip 21/;

Parameter TLT(I,J,h) Trucking cost in dollar per ton ;

$\mathrm{TLT}(\mathrm{I}, \mathrm{J}, \mathrm{h})=\mathrm{TC}(\mathrm{I}, \mathrm{J}) / \mathrm{TL}(\mathrm{h})$;

*Transportation distance within each county is assumed to be off-highway.

*The transportation cost rate was calculated using Jesen's WTRANS program. 
Parameter LTC(H) Transportation cost off highway within counties (\$ per ton.mile);

$\mathrm{LTC}(\mathrm{H})=2 *\left(\mathrm{FPG} / \mathrm{MPG} \_2+\mathrm{DWH} / \mathrm{MPH} \_2+\left((\mathrm{TP}-\mathrm{TP} * \mathrm{TSP}) *(1+\mathrm{MR})+\mathrm{IITR}^{*}((\mathrm{TP}-\mathrm{TP} * \mathrm{TSP})\right.\right.$

$\left.*(\mathrm{~N}+1) / 2+\mathrm{N} * \mathrm{TP} * \mathrm{TSP})) / \mathrm{N} / \mathrm{SMH} / \mathrm{UT} / \mathrm{MPH} \_2\right) / \mathrm{TL}(\mathrm{h})$;

Parameter FC(SI) Coefficients of linearized local transportation turnover function

$\begin{array}{ll}/ 1 & 1.583 \\ 2 & 3.322 \\ 3 & 4.738 \\ 4 & 6.474 \\ 5 & 9.156 \\ 6 & 11.856 \\ 7 & 14.040 \\ 8 & 15.925 \\ 9 & 18.377 /\end{array}$

Parameter B(SI) Right hand side of the constraints for separated variables in linearized function

$\begin{array}{ll}/ 1 & 1000 \\ 2 & 2000 \\ 3 & 2000 \\ 4 & 5000 \\ 5 & 10000 \\ 6 & 10000 \\ 7 & 10000 \\ 8 & 10000 \\ 9 & 25000 /\end{array}$

Scalar Millcost Cost of mill residues ( $\$$ per green ton) $/ 20 /$;

Scalar Mill_load Load of mill residues in green tons /21/;

Parameter Milltrancost Cost of delivering mill residues (\$ per ton per mile);

Milltrancost=2*(FPG/MPG_1+DWH/MPH_1+((TP-TP*TSP)*(1+MR)+IITR*((TP-TP*TSP)

$\left.*(\mathrm{~N}+1) / 2+\overline{\mathrm{N}} * \mathrm{TP} * \mathrm{TSP})) / \mathrm{N} / \overline{\mathrm{S} M H} / \mathrm{UT} / \mathrm{MPH} \_1\right) / \mathrm{Mill} \_l o a d ;$

Scalar TLoss Dry matter loss due to transportation /0.02/;

$* * * * * * * * * * * * * * * * * * * * * * * * * * * * * * * * * * * * * * * * * * * * * * * * * * * * * * * * * * * * * * * * * * * * * * * * * * * * * * *$

* Woody biomass-based biorefinery plant assumptions $\quad *$

$* * * * * * * * * * * * * * * * * * * * * * * * * * * * * * * * * * * * * * * * * * * * * * * * * * * * * * * * * * * * * * * * * * * * * * * * * * * * * * *$

Scalar Capacity Plant capacity in terms of feedstock (dry tons) per day /2000/;

Parameter N Plant life;

$\mathrm{N}=\mathrm{CARD}$ (project_year);

Scalar FT Federal tax applied to ethanol facility /0.39/;

Scalar Equity_prop Proportion of equity in the total investment /0.4/;

Scalar Re Cost of equity /0.15/;

Scalar Rd Cost of debt /0.08/; 
Parameter WACC Weighted average cost of capital;

WACC=Equity_prop*Re+(1-Equity_prop)*Rd*(1-FT);

Parameter PVI(Project_year) Present value index at each project year; PVI(Project_year) $=1 /$ Power((1+WACC),ORD(Project_year $))$;

Scalar M_S_97 Marshall \& Swift all industry equipment cost index in 1997/1056.8/;

Scalar M_S_07 Marshall \& Swift all industry equipment cost index in $2007 / 1373.3 /$;

Scalar GPD_97 Gross national product deflator index in $1997 / 95.851 /$;

Scalar GPD_07 Gross national product deflator index in 2007/120.737/;

Scalar Exponent $\quad$ Exponent indicator /0.7/;

Scalar R_cap Plant capacity in the reference in metric tons /2000/;

Parameter PEC_ref(Process_area) Plant equipment cost in the reference (\$)

/Feed_handling _ 4903353

Pretreatment 26320534

SSCF 13398435

Cellulase production 15540831

Distillation $\quad 12974545$

WWT 10381196

Storage 1820753

Boiler_turbogen $\quad 44465109$

Utilities $\quad 5220291 /$;

Parameter PEC(process_area) Plant equipment cost corresponding to demand level (\$);

PEC(process_area) $=$ PEC_ref(Process_area)*M_S_07/M_S_97*((Capacity/R_cap/1.1)**Exponent);

Parameter TEC Total equipment cost (\$);

TEC $=$ Sum(process_area, PEC(process_area));

Parameter WH Warehouse cost (\$);

$\mathrm{WH}=0.015^{*} \mathrm{TEC}$;

Parameter SD Site development (\$);

$\mathrm{SD}=0.09 *(\mathrm{PEC}($ "Feed_handling")+PEC("Pretreatment")+PEC("SSCF")+PEC("Cellulase_production") + PEC("Distillation"));

Parameter TIC Total installed cost (\$);

$\mathrm{TIC}=\mathrm{TEC}+\mathrm{WH}+\mathrm{SD}$;

Parameter Field_expense Field expenses (\$);

Field_expense $=0.1 *$ TIC;

Parameter Homeoffice_construction Home office and construction fee (\$);

Homeoffice_construction $=0.25 * \mathrm{TIC}$; 
Parameter Project_contingency Project contingency (\$);

Project_contingency $=0.03 *$ TIC;

Parameter Total_capital Total capital investment (\$);

Total_capital=TIC+Field_expense+Homeoffice_construction+Project_contingency;

Parameter Other_costs Other costs $(\$)$;

Other_costs $=0.1 *$ Total_capital;

Parameter TPC Total project investment (\$);

$\mathrm{TPC}=($ Total_capital + other_costs $)$;

Parameter TPCC(J);

$\operatorname{TPCC}(\mathrm{J})=\mathrm{TPC}$;

Scalar R_Non_feedstock Non-feedstock raw material cost (1997\$) in the reference /8350000/;

Scalar R_water Water cost (1997\$) in the reference /450000/;

Scalar R_Waste_disposal Waste disposal cost in the reference (1997\$) /610000/;

Parameter Non_feedstock Non-feedstock raw material cost (2007\$);

Non_feedstock=R_Non_feedstock*(GPD_07/GPD_97)*(Capacity/R_cap/1.1);

Parameter Waste_disposal Waste disposal cost (2007\$);

Waste_disposal=R_Waste_disposal*(GPD_07/GPD_97)*(Capacity/R_cap/1.1);

Parameter Water Water cost (2007\$);

Water=R_Water*(GPD_07/GPD_97)*(Capacity/R_cap/1.1);

Scalar R_Salary Total salaries in the reference (1997\$) /1532000/;

Parameter T_salary Total salary $(2007 \$)$;

T_salary=R_salary*GPD_07/GPD_97*((Capacity/R_cap/1.1)**Exponent);

Parameter Direct_Overhead Direct Overhead (\$);

Direct_Overhead $=0.6 * \mathrm{~T} \_$salary;

Parameter Maintenance Maintenance (\$);

Maintenance $=0.03 *$ TEC;

Parameter Insurance Insurance and taxes (\$);

Insurance $=0.015^{*} \mathrm{TIC}$;

Parameter T_fixed_oper Total fixed operating costs $(\$)$;

T_fixed_oper=T_salary+Direct_Overhead+Maintenance+Insurance;

Parameter OM Annual operating and maintenance cost without general overhead (\$); $\mathrm{OM}=\mathrm{T}$ _fixed_oper+ Non_feedstock + water + Waste_disposal; 


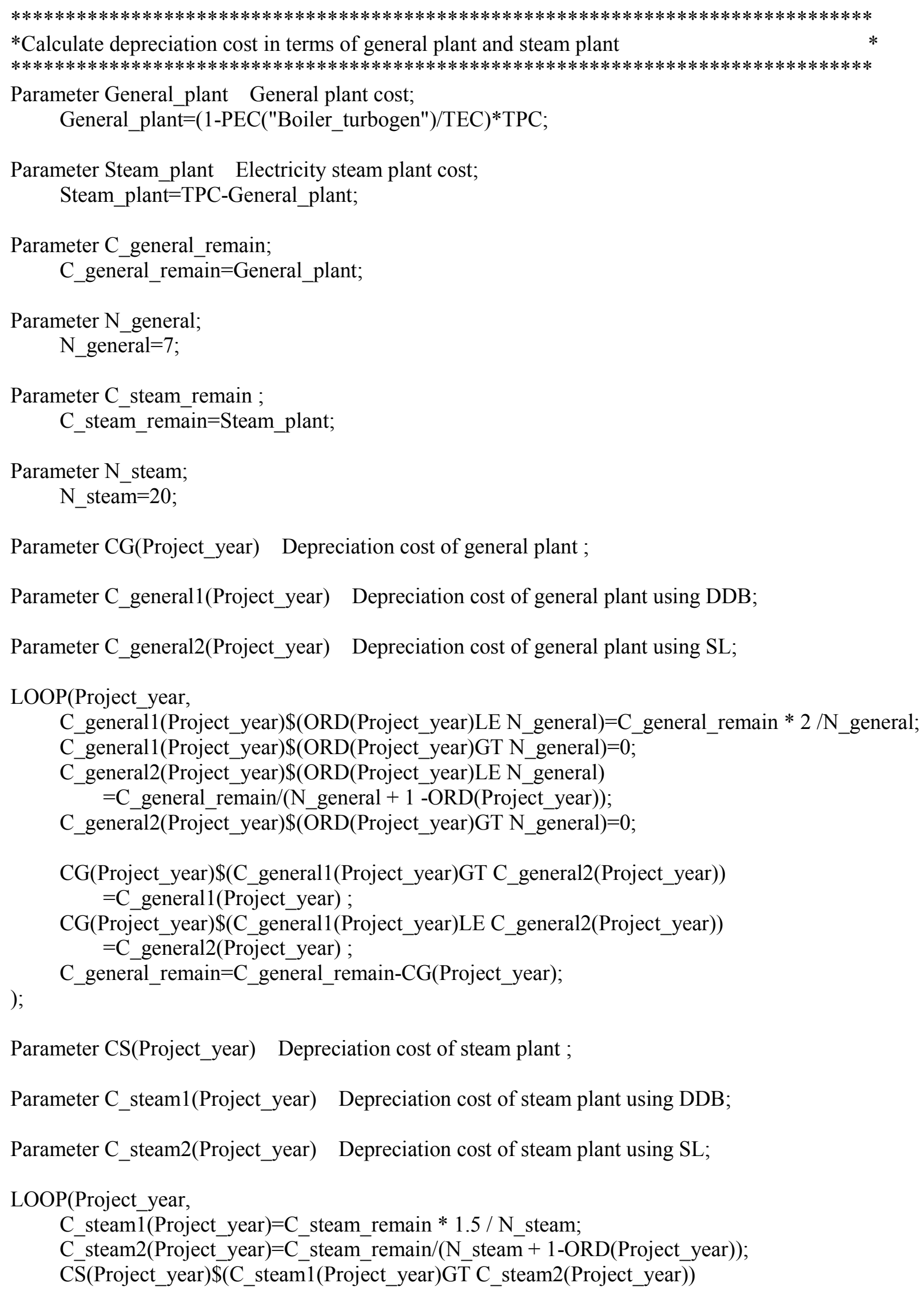




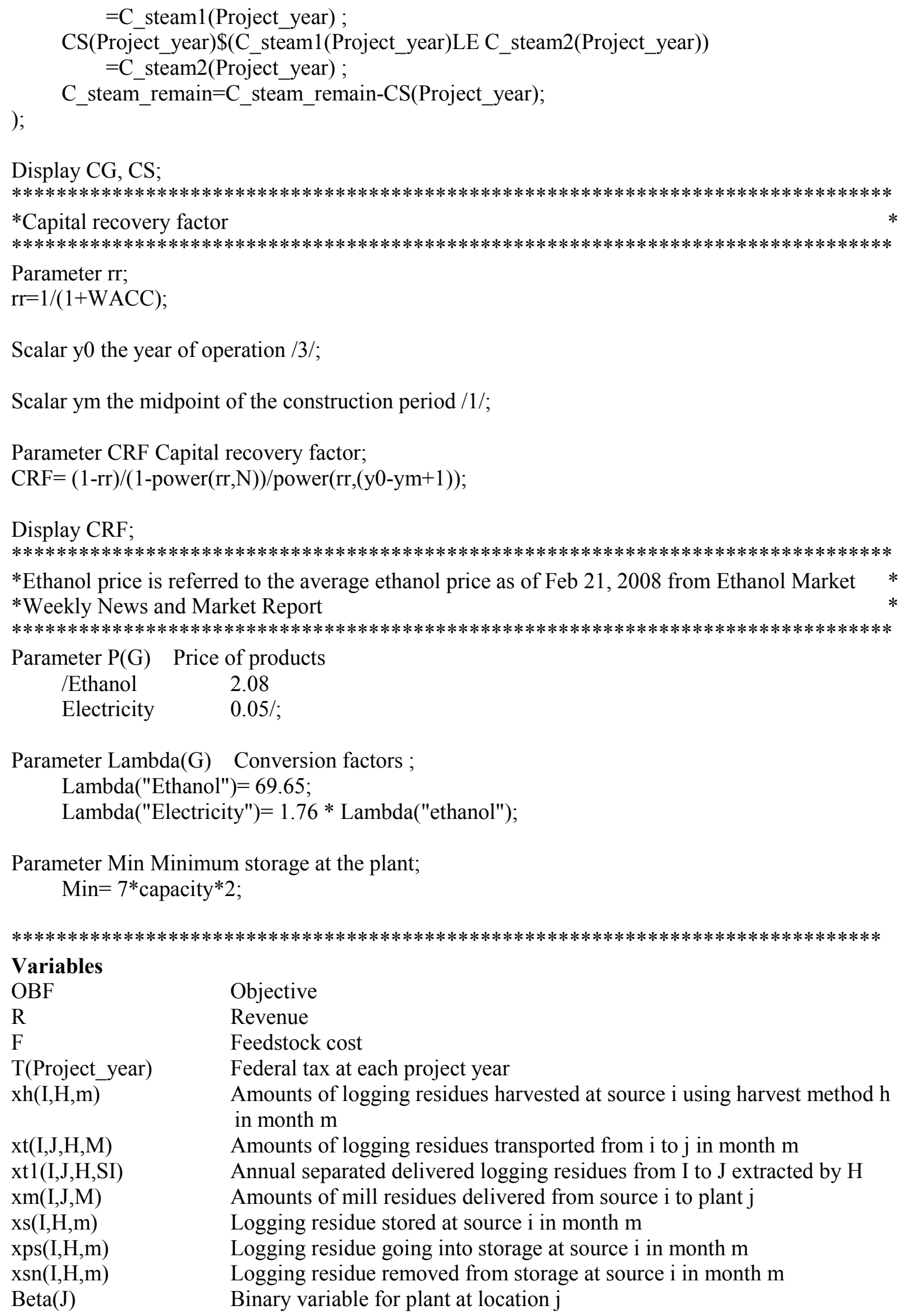




$\begin{array}{ll}\text { Alfa }(\mathrm{I}, \mathrm{H}) & \text { Binary variable for harvesting method } \\ \text { Q(J,G,M) } & \text { Production of product } \mathrm{G} \text { at location } \mathrm{j} \text { in month } \mathrm{m} \\ \mathrm{SS}(\mathrm{J}, \mathrm{M}) & \text { Woody biomass stored at plant } \mathrm{j} \text { in month } \mathrm{m} \\ \mathrm{SP}(\mathrm{J}, \mathrm{M}) & \text { Woody biomass processed at plant } \mathrm{j} \text { in month } \mathrm{m} \\ \text {; } & \\ \text { Positive Variables xh, xt, xt1, xm, xs, xps, xsn, Q, SS, SP; } \\ \text { Binary Variables Beta, Alfa; }\end{array}$

\section{Equations}

Obj

Revenue

Feedstock

Tax(Project_year)

Tax1(Project_year)

Logresidue(I,H)

HSlope35(I,H)

Ext_limt_1(I,H,M)

Ext_limt_2(I,H,M)

Ext_limt_3(I,H,M)

Ext_limt_4(I,H,M)

Trans $(\mathrm{I}, \mathrm{J}, \mathrm{H})$

Tran_con1(I,J,H,SI)

Storage1(I,H,M)

Storage2(I)

Storage3(I,M)

Milltrant(I)

MXplant

MXHarvest(I)

One(I)

P1(J,M)

P2(J,M)

P3(J,M)

Conversion $(\mathrm{J}, \mathrm{G}, \mathrm{M})$

;

Obj..

$$
\begin{aligned}
\mathrm{OBF}= & \mathrm{E}= \\
& =\text { sum }(\text { Project_year, }(\mathrm{R}-\mathrm{F}-\mathrm{O}-\mathrm{OM}-0.06 * \mathrm{~J}, \mathrm{Beta}(\mathrm{J}) * \mathrm{TPC}(\mathrm{J})) ;
\end{aligned}
$$

Revenue..

$$
\text { R-sum((J,G,M),P(G)*Q(J,G,M))=E=0; }
$$

Feedstock..

F-(sum((I,H,M),(EC(H)+stumpage)* xh(I,H,M))+sum((I,H,M), SC *xps(I,H,m))

$+\operatorname{sum}\left((\mathrm{I}, \mathrm{J}, \mathrm{H}, \mathrm{M}),(\mathrm{ChippingSite}(\mathrm{H})+\mathrm{LC}(\mathrm{H})+\mathrm{TLT}(\mathrm{I}, \mathrm{J}, \mathrm{H})+\mathrm{ChippingPlant}(\mathrm{H}))^{*} \mathrm{xt}(\mathrm{I}, \mathrm{J}, \mathrm{H}, \mathrm{M})\right)$

+ sum((I,J,H,SI)\$(Dis(I,J) LE LoggingResidue(I,"Intradistance")), LTC(H)*FC(SI)*xt1(I,J,H,SI))

+ Millcost * $\operatorname{sum}((\mathrm{I}, \mathrm{J}, \mathrm{M}), \mathrm{xm}(\mathrm{I}, \mathrm{J}, \mathrm{M}))+\operatorname{sum}((\mathrm{I}, \mathrm{J}, \mathrm{M})$, Milltrancost * Dis $(\mathrm{I}, \mathrm{J}) * \mathrm{xm}(\mathrm{I}, \mathrm{J}, \mathrm{M})))=\mathrm{E}=0$;

Tax(Project_year)\$(ORD(Project_year) GT 1).. $\mathrm{T}$ (Project_year)-(R-F-OM-0.06*R-CG(Project_year)-CS(Project_year))*ft=E=0; 
Tax1(Project_year) $\$(O R D$ (Project_year) EQ 1)..

$\mathrm{T}$ (Project_year) $=\mathrm{E}=0$;

Logresidue( $(\mathrm{I}, \mathrm{H})$.. $\operatorname{sum}(\mathrm{M}, \mathrm{xh}(\mathrm{I}, \mathrm{H}, \mathrm{M}))-\mathrm{Alfa}(\mathrm{I}, \mathrm{H}) * \operatorname{loggingavai}(\mathrm{I})=\mathrm{L}=0 ;$

HSlope35(I,H).. $\operatorname{sum}(\mathrm{M}, \mathrm{xh}(\mathrm{I}, \mathrm{H}, \mathrm{M}))-\mathrm{Alfa}(\mathrm{I}, \mathrm{H}) * \operatorname{loggingSlope}(\mathrm{I})=\mathrm{L}=0$;

Ext_limt_1(I,H,M).. $\overline{x h}(\mathrm{I}, \mathrm{H}, \mathrm{M})-\mathrm{Ext} \operatorname{amt}(\mathrm{I}, \mathrm{H}, \mathrm{M})=\mathrm{L}=0$;

Ext_limt_2(I,H,M)\$(ord(H) LE 2).. $\overline{\mathrm{xh}}(\mathrm{I}, \mathrm{H}, \mathrm{M})-20 * 80 * 1.5 * \mathrm{PD}(\mathrm{H}) / 35.3 * 0.77=\mathrm{L}=0$;

Ext_limt_3(I,H,M)\$(ord(H) EQ 3 or ord(H) EQ 4).. $\mathrm{xh}(\mathrm{I}, \mathrm{H}, \mathrm{M})-20 * 80 * 1.6 * \mathrm{PD}(\mathrm{H}) / 35.3 * 0.77=\mathrm{L}=0$;

Ext_limt_4(I,H,M)\$(ord(H) GE 5).. $\overline{\mathrm{xh}}(\mathrm{I}, \mathrm{H}, \mathrm{M})-20 * 80 * 1 * \mathrm{PD}(\mathrm{H}) / 35.3 * 0.77=\mathrm{L}=0$;

$\operatorname{Trans}(\mathrm{I}, \mathrm{J}, \mathrm{H})$. $\operatorname{sum}(\mathrm{SI}, \mathrm{xt} 1(\mathrm{I}, \mathrm{J}, \mathrm{H}, \mathrm{SI}))-\operatorname{sum}(\mathrm{M}, \mathrm{xt}(\mathrm{I}, \mathrm{J}, \mathrm{H}, \mathrm{M}))=\mathrm{E}=0$;

Tran_con1(I,J,H,SI).. $x t 1(\mathrm{I}, \mathrm{J}, \mathrm{H}, \mathrm{SI})=\mathrm{L}=\mathrm{B}(\mathrm{SI})$;

Storage1(I,H,M).. $\mathrm{xh}(\mathrm{I}, \mathrm{H}, \mathrm{M})+\mathrm{UPS}^{*} \mathrm{xs}(\mathrm{I}, \mathrm{H}, \mathrm{M}-1)-\operatorname{sum}(\mathrm{J}, \mathrm{xt}(\mathrm{I}, \mathrm{J}, \mathrm{H}, \mathrm{M}))-\mathrm{xs}(\mathrm{I}, \mathrm{H}, \mathrm{M})=\mathrm{G}=0$;

Storage2(I).. $\operatorname{sum}((H, M), x h(I, H, M))-\operatorname{sum}((J, H, M), x t(I, J, H, M))-(1-U P S) * \operatorname{sum}((H, M), x s(I, H, M))=E=0 ;$

Storage3(I,M).. $\operatorname{sum}(\mathrm{H}, \mathrm{xh}(\mathrm{I}, \mathrm{H}, \mathrm{M}))-\operatorname{sum}(\mathrm{H}, \mathrm{xps}(\mathrm{I}, \mathrm{H}, \mathrm{M}))+\operatorname{sum}(\mathrm{H}, \mathrm{xsn}(\mathrm{I}, \mathrm{H}, \mathrm{M}))-\operatorname{sum}((\mathrm{J}, \mathrm{H}), \mathrm{xt}(\mathrm{I}, \mathrm{J}, \mathrm{H}, \mathrm{M}))=\mathrm{E}=0$;

Milltrant(I).. $\operatorname{sum}((\mathrm{J}, \mathrm{M}), \mathrm{xm}(\mathrm{I}, \mathrm{J}, \mathrm{M}))-\operatorname{MillProp}(\mathrm{I}) * \operatorname{MillResidue}(\mathrm{I})=\mathrm{L}=0$;

MXplant.. $\operatorname{sum}(\mathrm{J}, \operatorname{Beta}(\mathrm{J}))=\mathrm{E}=1$;

MXHarvest(I)..

One(I).. $\operatorname{sum}(\mathrm{H}, \operatorname{Alfa}(\mathrm{I}, \mathrm{H}))=\mathrm{E}=1$;

P1(J,M).. Alfa(I, "Cable-skidder") $=\mathrm{E}=1$; $\operatorname{sum}(\mathrm{I}, \mathrm{xm}(\mathrm{I}, \mathrm{J}, \mathrm{M}))+\operatorname{sum}((\mathrm{I}, \mathrm{H}), \mathrm{xt}(\mathrm{I}, \mathrm{J}, \mathrm{H}, \mathrm{M})) *(1-\mathrm{TLoss})+\mathrm{UPS} * \mathrm{SS}(\mathrm{J}, \mathrm{M}-1)-\mathrm{SP}(\mathrm{J}, \mathrm{M})-\mathrm{SS}(\mathrm{J}, \mathrm{M})=\mathrm{E}=0 ;$

P2(J,M).. $\mathrm{SS}(\mathrm{J}, \mathrm{M})-\mathrm{MIN} * \operatorname{Beta}(\mathrm{J})=\mathrm{G}=0 ;$ 
$\mathrm{P} 3(\mathrm{~J}, \mathrm{M})$.

$(1-\mathrm{WC}) * \mathrm{SP}(\mathrm{J}, \mathrm{M})-30 *$ Capacity* $\operatorname{Beta}(\mathrm{J})=\mathrm{E}=0$;

Conversion(J,G,M)..

$\mathrm{Q}(\mathrm{J}, \mathrm{G}, \mathrm{M})-(1-\mathrm{WC}) * \mathrm{Lambda}(\mathrm{G}) * \mathrm{SP}(\mathrm{J}, \mathrm{M})=\mathrm{L}=0$;

$* * * * * * * * * * * * * * * * * * * * * * * * * * * * * * * * * * * * * * * * * * * * * * * * * * * * * * * * * * * * * * * * * * * * * * * * * * * * * * *$

*Solve the model

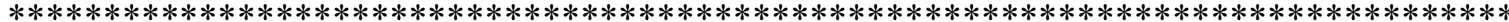

Model Bioplant/all/;

Solve Bioplant maximizing OBF using MIP;

Option solprint $=$ off;

$* * * * * * * * * * * * * * * * * * * * * * * * * * * * * * * * * * * * * * * * * * * * * * * * * * * * * * * * * * * * * * * * * * * * * * * * * * * * * * *$

*Results

$* * * * * * * * * * * * * * * * * * * * * * * * * * * * * * * * * * * * * * * * * * * * * * * * * * * * * * * * * * * * * * * * * * * * * * * * * * * * * * * * * *$

Parameter Adj_tax(project_year) Adjusted tax for each project year;

Adj_tax(project year)\$((R.1-F.1-(OM+0.06*R.1)-CG(Project_year)-CS(Project year) $)<=0)=0$;

Adj_tax(project year)\$((R.1-F.1-(OM+0.06*R.1)-CG(Project_year)-CS(Project year)) >0) $=(\mathrm{R} .1-\mathrm{F} .1-(\mathrm{OM}+0.06 * \mathrm{R} .1)-\mathrm{CG}(\text { Project year })-\mathrm{CS}(\text { Project_year }))^{*} \mathrm{FT}$;

Display Adj_tax;

Parameter T OM Total operation and maintenance cost;

$\mathrm{T}$ OM$=\mathrm{OM}+0.06 * \mathrm{R} .1$;

Display T_OM;

Parameter Adj_obj Adjusted net present value;

Adj_obj=SUM(Project_year,((R.1-F.1-OM-0.06*R.1-Adj_tax(project_year))*PVI(Project_year))) $-\operatorname{sum}(\mathrm{J}, \mathrm{TPCC}(\mathrm{J}) *$ beta.1(J));

Display Adj_obj;

$* * * * * * * * * * * * * * * * * * * * * * * * * * * * * * * * * * * * * * * * * * * * * * * * * * * * * * * * * * * * * * * * * * * * * * * * * * * * * * * *$

*Ethanol production cost per gallon $\quad *$

*c1-capital cost; c2-feedstock cost (biomass); c3-non-feedstock cost; c4-water cost; $\quad *$

*c5-waste disposal; c6-salary; c7-maintenance cost; c8-direct overhead; c9-sales related overhead *

$*_{\mathrm{c} 10}$-insurance; c11-electricity credit

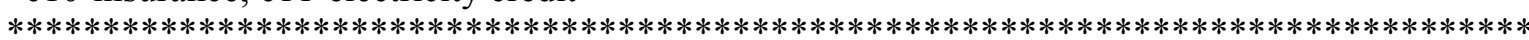

Parameter c1,c2,c3,c4,c5,c6,c7,c8,c9,c10,c11, c12 unit cost by category and total cost per gallon; $\mathrm{c} 1=\operatorname{sum}(\mathrm{J}, \operatorname{Beta} .1(\mathrm{~J}) * \mathrm{TPCC}(\mathrm{J}))^{*} \mathrm{CRF} / \operatorname{sum}((\mathrm{J}, \mathrm{G}, \mathrm{M}) \$(\operatorname{ord}(\mathrm{G})$ EQ 1),Q.L(J,G,M));

c2=F.L/sum((J,G,M)\$(ord(G) EQ 1),Q.L(J,G,M));

c3=Non_feedstock/sum $((J, G, M) \$(\operatorname{ord}(G)$ EQ 1),Q.L(J,G,M));

c4=Water/sum((J,G,M)\$(ord(G) EQ 1),Q.L(J,G,M));

c5=Waste_disposal/sum((J,G,M)\$(ord(G) EQ 1),Q.L(J,G,M)); 


$$
\begin{aligned}
& \text { c6=T_salary/sum }((\mathrm{J}, \mathrm{G}, \mathrm{M}) \$(\operatorname{ord}(\mathrm{G}) \text { EQ 1),Q.L(J,G,M)); } \\
& \text { c7=Maintenance/sum }((\mathrm{J}, \mathrm{G}, \mathrm{M}) \$(\operatorname{ord}(\mathrm{G}) \text { EQ 1),Q.L(J,G,M)); } \\
& \text { c8=Direct_overhead/sum((J,G,M)\$(ord(G) EQ 1),Q.L(J,G,M)); } \\
& \text { c9=0.06*R.1/sum((J,G,M)\$(ord(G) EQ 1),Q.L(J,G,M)); } \\
& \text { c10=Insurance/sum((J,G,M)\$(ord(G) EQ 1),Q.L(J,G,M)); } \\
& \text { c11=1.76*P("Electricity"); } \\
& \text { c12=c1+c2+c3+c4+c5+c6+c7+c8+c9+c10 - c11; }
\end{aligned}
$$

Display c1,c2,c3,c4,c5,c6,c7,c8,c9,c10,c11,c12;

\begin{abstract}
*Woody biomass delivered per year
,

Parameter Trans_log, Trans_mill;

Trans_log=sum((I,J,H,M $), x t .1(\mathrm{I}, \mathrm{J}, \mathrm{H}, \mathrm{M}))$;

Trans_mill=sum((I,J,M),xm.1(I,J,M));

Display Trans_log, Trans_mill;

$* * * * * * * * * * * * * * * * * * * * * * * * * * * * * * * * * * * * * * * * * * * * * * * * * * * * * * * * * * * * * * * * * * * * * * * * * * * * * * *$
$*$ End of code
$*$ Note: Some data are stored in the Excel spreadsheets and not visible in the GAMS code. The
$*$ followings are the detailed data.
$* * * * * * * * * * * * * * * * * * * * * * * * * * * * * * * * * * * * * * * * * * * * * * * * * * * * * * * * * * * * * * * * * * * * * * * * * * * *$
\end{abstract}

PARAMETER dis

$\begin{array}{llllll} & \text { Beaver_Raleigh } & \text { Belington } & \text { Bluefield } & \text { Buckhannon } & \text { Holden } \\ \text { Barbour } & 114.000 & 11.000 & 145.000 & 15.000 & 143.000 \\ \text { Boone } & 42.000 & 121.000 & 64.000 & 107.000 & 20.000 \\ \text { Braxton } & 67.000 & 51.000 & 100.000 & 33.000 & 94.000 \\ \text { Cabell } & 72.000 & 126.000 & 95.000 & 110.000 & 43.000 \\ \text { Calhoun } & 81.000 & 63.000 & 115.000 & 47.000 & 91.000 \\ \text { Clay } & 50.000 & 73.000 & 83.000 & 57.000 & 69.000 \\ \text { Doddridge } & 109.000 & 49.000 & 142.000 & 37.000 & 122.000 \\ \text { Fayette } & 22.000 & 92.000 & 55.000 & 80.000 & 53.000 \\ \text { Gilmer } & 84.000 & 49.000 & 118.000 & 33.000 & 101.000 \\ \text { Grant } & 140.000 & 44.000 & 165.000 & 59.000 & 177.000 \\ \text { Greenbrier } & 47.000 & 75.000 & 69.000 & 69.000 & 94.000 \\ \text { Hampshire } & 171.000 & 67.000 & 196.000 & 82.000 & 206.000 \\ \text { Hardy } & 150.000 & 52.000 & 175.000 & 67.000 & 187.000 \\ \text { Harrison } & 115.000 & 28.000 & 147.000 & 21.000 & 136.000 \\ \text { Jackson } & 80.000 & 96.000 & 111.000 & 81.000 & 70.000\end{array}$




\begin{tabular}{|c|c|c|c|c|c|}
\hline Kanawha & 45.000 & 98.000 & 75.000 & 84.000 & 46.000 \\
\hline Lewis & 97.000 & 29.000 & 129.000 & 14.000 & 119.000 \\
\hline Lincoln & 64.000 & 128.000 & 85.000 & 113.000 & 32.000 \\
\hline Logan & 46.000 & 137.000 & 59.000 & 124.000 & 5.000 \\
\hline Marion & 34.000 & 38.000 & 19.000 & 133.000 & 42.000 \\
\hline Mcdowell & 147.000 & 144.000 & 180.000 & 70.000 & 161.000 \\
\hline Mason & 82.000 & 110.000 & 110.000 & 95.000 & 63.000 \\
\hline Mercer & 26.000 & 130.000 & 10.000 & 121.000 & 61.000 \\
\hline Mineral & 157.000 & 49.000 & 185.000 & 64.000 & 191.000 \\
\hline Mingo & 54.000 & 152.000 & 57.000 & 135.000 & 9.000 \\
\hline Monongalia & 146.000 & 42.000 & 178.000 & 47.000 & 170.000 \\
\hline Monroe & 35.000 & 104.000 & 44.000 & 98.000 & 85.000 \\
\hline Nicholas & 41.000 & 71.000 & 74.000 & 59.000 & 72.000 \\
\hline Pleasants & 115.000 & 72.000 & 148.000 & 59.000 & 119.000 \\
\hline Pendleton & 117.000 & 42.000 & 140.000 & 52.000 & 154.000 \\
\hline Pocahontas & 67.000 & 56.000 & 91.000 & 53.000 & 110.000 \\
\hline Preston & 143.000 & 34.000 & 174.000 & 45.000 & 171.000 \\
\hline Putnam & 67.000 & 110.000 & 95.000 & 95.000 & 47.000 \\
\hline Raleigh & 4.000 & 109.000 & 36.000 & 99.000 & 46.000 \\
\hline Randolph & 103.000 & 13.000 & 131.000 & 21.000 & 137.000 \\
\hline Ritchie & 102.000 & 61.000 & 135.000 & 47.000 & 109.000 \\
\hline Roane & 74.000 & 78.000 & 107.000 & 62.000 & 77.000 \\
\hline Summers & 16.000 & 107.000 & 33.000 & 98.000 & 66.000 \\
\hline Taylor & 126.000 & 22.000 & 158.000 & 27.000 & 153.000 \\
\hline Tucker & 124.000 & 17.000 & 152.000 & 33.000 & 158.000 \\
\hline Tyler & 122.000 & 61.000 & 155.000 & 51.000 & 132.000 \\
\hline Upshur & 100.000 & 16.000 & 131.000 & 0.000 & 127.000 \\
\hline Wayne & 78.000 & 146.000 & 94.000 & 131.000 & 35.000 \\
\hline Webster & 65.000 & 45.000 & 95.000 & 36.000 & 99.000 \\
\hline Wetzel & 128.000 & 55.000 & 162.000 & 46.000 & 142.000 \\
\hline Wirt & 92.000 & 79.000 & 125.000 & 63.000 & 93.000 \\
\hline Wood & 101.000 & 85.000 & 133.000 & 70.000 & 99.000 \\
\hline Wyoming & 24.000 & 132.000 & 28.000 & 121.000 & 34.000 \\
\hline V_Alleghany & 58.000 & 86.000 & 71.000 & 83.000 & 108.000 \\
\hline V_Buchanan & 62.000 & 170.000 & 48.000 & 158.000 & 40.000 \\
\hline V_Bath & 88.000 & 64.000 & 106.000 & 68.000 & 135.000 \\
\hline V_Bland & 44.000 & 147.000 & 12.000 & 139.000 & 72.000 \\
\hline V_Craig & 53.000 & 112.000 & 54.000 & 108.000 & 103.000 \\
\hline $\mathrm{V}^{-}$Dickenson & 80.000 & 188.000 & 65.000 & 175.000 & 52.000 \\
\hline V_Giles & 40.000 & 123.000 & 32.000 & 117.000 & 86.000 \\
\hline $\mathrm{V}_{-}^{-}$Highland & 97.000 & 46.000 & 120.000 & 53.000 & 142.000 \\
\hline V_Russell & 72.000 & 181.000 & 50.000 & 170.000 & 57.000 \\
\hline V_Smyth & 61.000 & 170.000 & 31.000 & 161.000 & 68.000 \\
\hline V_Tazewell & 47.000 & 157.000 & 19.000 & 147.000 & 56.000 \\
\hline V_Wise & 95.000 & 202.000 & 78.000 & 189.000 & 64.000 \\
\hline K_Boyd & 94.000 & 156.000 & 110.000 & 141.000 & 50.000 \\
\hline $\mathrm{K}$ Carter & 106.000 & 169.000 & 120.000 & 154.000 & 60.000 \\
\hline $\mathrm{K} \_$Elliott & 115.000 & 185.000 & 125.000 & 170.000 & 66.000 \\
\hline K_Floyd & 89.000 & 183.000 & 87.000 & 169.000 & 42.000 \\
\hline K_Greenup & 108.000 & 159.000 & 126.000 & 143.000 & 67.000 \\
\hline K_Johnson & 98.000 & 183.000 & 102.000 & 168.000 & 48.000 \\
\hline
\end{tabular}




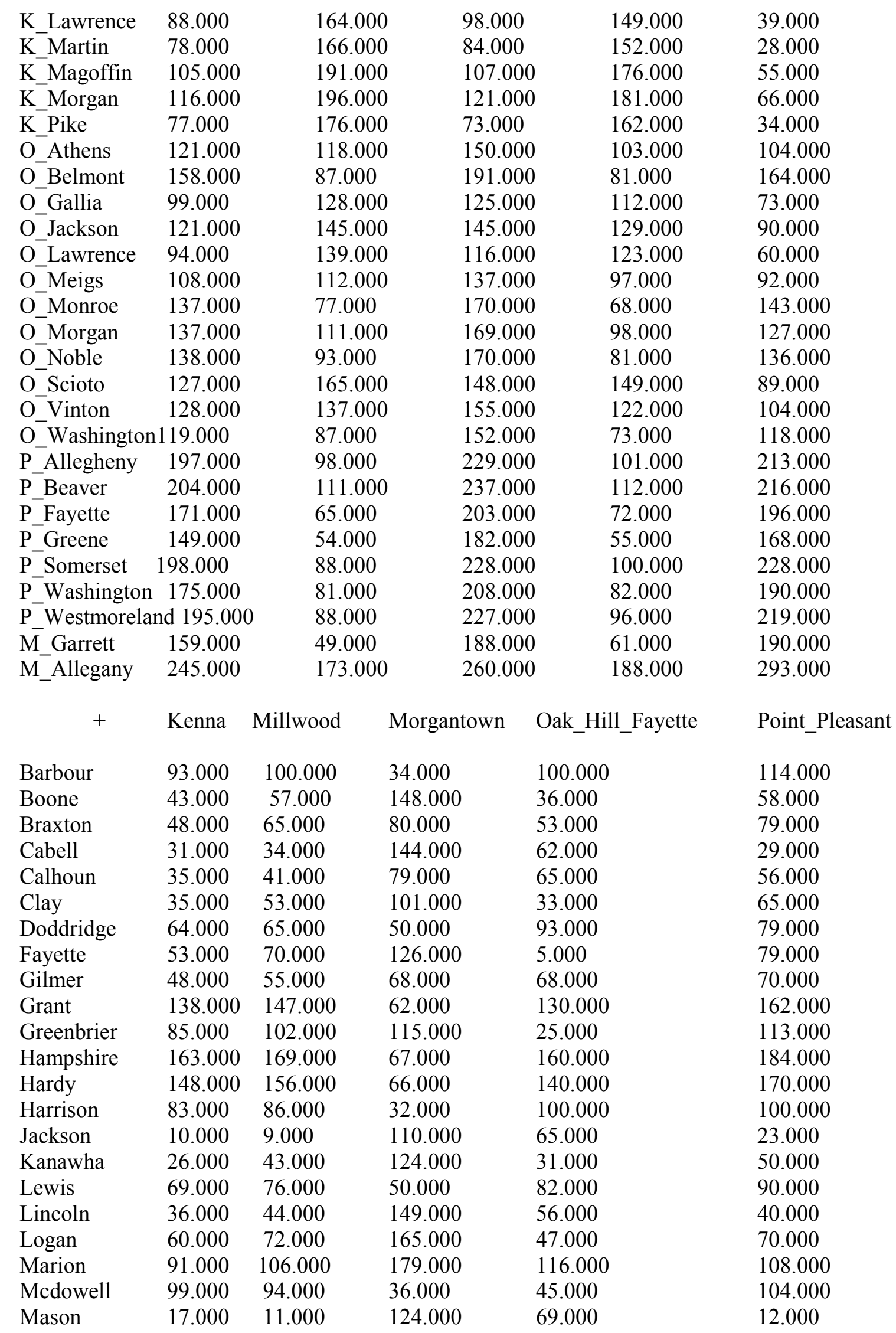




\begin{tabular}{|c|c|c|c|c|c|}
\hline Mercer & 95.000 & 112.000 & 168.000 & 42.000 & 117.000 \\
\hline Mineral & 143.000 & 150.000 & 46.000 & 145.000 & 164.000 \\
\hline Mingo & 75.000 & 81.000 & 181.000 & 60.000 & 79.000 \\
\hline Monongalia & 113.000 & 115.000 & 0.000 & 131.000 & 129.000 \\
\hline Monroe & 96.000 & 114.000 & 145.000 & 43.000 & 123.000 \\
\hline Nicholas & 52.000 & 69.000 & 105.000 & 27.000 & 80.000 \\
\hline Pleasants & 56.000 & 51.000 & 68.000 & 98.000 & 63.000 \\
\hline Pendleton & 126.000 & 135.000 & 76.000 & 109.000 & 149.000 \\
\hline Pocahontas & 91.000 & 106.000 & 98.000 & 60.000 & 119.000 \\
\hline Preston & 120.000 & 124.000 & 18.000 & 132.000 & 138.000 \\
\hline Putnam & 16.000 & 27.000 & 129.000 & 55.000 & 28.000 \\
\hline Raleigh & 67.000 & 85.000 & 144.000 & 15.000 & 91.000 \\
\hline Randolph & 97.000 & 107.000 & 55.000 & 91.000 & 122.000 \\
\hline Ritchie & 49.000 & 49.000 & 66.000 & 85.000 & 63.000 \\
\hline Roane & 19.000 & 28.000 & 95.000 & 58.000 & 42.000 \\
\hline Summers & 82.000 & 100.000 & 145.000 & 26.000 & 107.000 \\
\hline Taylor & 100.000 & 104.000 & 21.000 & 112.000 & 118.000 \\
\hline Tucker & 113.000 & 121.000 & 42.000 & 112.000 & 136.000 \\
\hline Tyler & 69.000 & 66.000 & 52.000 & 105.000 & 79.000 \\
\hline Upshur & 80.000 & 88.000 & 47.000 & 86.000 & 103.000 \\
\hline Wayne & 53.000 & 55.000 & 166.000 & 72.000 & 47.000 \\
\hline Webster & 69.000 & 83.000 & 84.000 & 53.000 & 97.000 \\
\hline Wetzel & 81.000 & 80.000 & 39.000 & 112.000 & 93.000 \\
\hline Wirt & 30.000 & 28.000 & 87.000 & 76.000 & 42.000 \\
\hline Wood & 36.000 & 28.000 & 89.000 & 85.000 & 40.000 \\
\hline Wyoming & 76.000 & 94.000 & 165.000 & 35.000 & 96.000 \\
\hline V_Alleghany & 105.000 & 122.000 & 128.000 & 59.000 & 132.000 \\
\hline V_Buchanan & 102.000 & 115.000 & 202.000 & 73.000 & 112.000 \\
\hline V_Bath & 117.000 & 132.000 & 106.000 & 84.000 & 145.000 \\
\hline V_Bland & 113.000 & 129.000 & 186.000 & 61.000 & 133.000 \\
\hline $\mathrm{V}^{-}$Craig & 115.000 & 133.000 & 154.000 & 62.000 & 142.000 \\
\hline V_Dickenson & 115.000 & 126.000 & 219.000 & 91.000 & 122.000 \\
\hline V_Giles & 109.000 & 127.000 & 164.000 & 53.000 & 133.000 \\
\hline V_Highland & 114.000 & 128.000 & 87.000 & 90.000 & 141.000 \\
\hline V_Russell & 118.000 & 131.000 & 215.000 & 84.000 & 128.000 \\
\hline V_Smyth & 121.000 & 136.000 & 207.000 & 77.000 & 137.000 \\
\hline V_Tazewell & 107.000 & 123.000 & 193.000 & 63.000 & 124.000 \\
\hline V_Wise & 128.000 & 137.000 & 232.000 & 105.000 & 132.000 \\
\hline K_Boyd & 61.000 & 59.000 & 173.000 & 88.000 & 47.000 \\
\hline $\mathrm{K}_{-}^{-}$Carter & 73.000 & 69.000 & 184.000 & 100.000 & 57.000 \\
\hline K_Elliott & 90.000 & 86.000 & 201.000 & 112.000 & 74.000 \\
\hline $\mathrm{K}$-Floyd & 98.000 & 103.000 & 209.000 & 93.000 & 96.000 \\
\hline K_Greenup & 64.000 & 56.000 & 171.000 & 100.000 & 42.000 \\
\hline K_Johnson & 92.000 & 94.000 & 205.000 & 99.000 & 84.000 \\
\hline $\mathrm{K}$-Lawrence & 71.000 & 73.000 & 184.000 & 85.000 & 63.000 \\
\hline K_Martin & 79.000 & 84.000 & 191.000 & 79.000 & 77.000 \\
\hline $\mathrm{K} \_$_Magoffin & 100.000 & 102.000 & 213.000 & 106.000 & 92.000 \\
\hline K_Morgan & 102.000 & 101.000 & 215.000 & 116.000 & 89.000 \\
\hline K_Pike & 95.000 & 103.000 & 204.000 & 83.000 & 97.000 \\
\hline O_Athens & 50.000 & 33.000 & 117.000 & 106.000 & 32.000 \\
\hline $\mathrm{O}_{-}^{-}$Belmont & 101.000 & 93.000 & 59.000 & 141.000 & 103.000 \\
\hline
\end{tabular}




\begin{tabular}{|c|c|c|c|c|c|}
\hline O_Gallia & 37.000 & 24.000 & 137.000 & 87.000 & 9.000 \\
\hline O_Jackson & 58.000 & 43.000 & 149.000 & 109.000 & 30.000 \\
\hline O_Lawrence & 43.000 & 37.000 & 152.000 & 84.000 & 24.000 \\
\hline O_Meigs & 38.000 & 20.000 & 116.000 & 93.000 & 21.000 \\
\hline O_Monroe & 79.000 & 72.000 & 60.000 & 120.000 & 83.000 \\
\hline O_Morgan & 68.000 & 53.000 & 101.000 & 121.000 & 57.000 \\
\hline O_Noble & 73.000 & 63.000 & 78.000 & 121.000 & 71.000 \\
\hline O_Scioto & 73.000 & 61.000 & 171.000 & 118.000 & 47.000 \\
\hline O_Vinton & 60.000 & 43.000 & 137.000 & 115.000 & 35.000 \\
\hline O_Washington & 55.000 & 45.000 & 82.000 & 103.000 & 55.000 \\
\hline P_Allegheny & 151.000 & 147.000 & 55.000 & 181.000 & 159.000 \\
\hline P_Beaver & 153.000 & 147.000 & 70.000 & 188.000 & 157.000 \\
\hline P_Fayette & 138.000 & 139.000 & 26.000 & 157.000 & 152.000 \\
\hline $\mathrm{P}_{-}^{-}$Greene & 109.000 & 108.000 & 17.000 & 134.000 & 121.000 \\
\hline P_Somerset & 174.000 & 176.000 & 61.000 & 185.000 & 190.000 \\
\hline P_Washington & 128.000 & 124.000 & 40.000 & 159.000 & 136.000 \\
\hline $\mathrm{P}_{-}^{-}$Westmorelan & a 160.000 & 159.000 & 49.000 & 180.000 & 172.000 \\
\hline M_Garrett & 138.000 & 142.000 & 32.000 & 146.000 & 157.000 \\
\hline M_Allegany & 264.000 & 275.000 & 185.000 & 241.000 & 290.000 \\
\hline+ & Williamson & & & & \\
\hline Barbour & 158.000 & & & & \\
\hline Boone & 37.000 & & & & \\
\hline Braxton & 110.000 & & & & \\
\hline Cabell & 53.000 & & & & \\
\hline Calhoun & 107.000 & & & & \\
\hline Clay & 86.000 & & & & \\
\hline Doddridge & 138.000 & & & & \\
\hline Fayette & 69.000 & & & & \\
\hline Gilmer & 117.000 & & & & \\
\hline Grant & 194.000 & & & & \\
\hline Greenbrier & 107.000 & & & & \\
\hline Hampshire & 223.000 & & & & \\
\hline Hardy & 203.000 & & & & \\
\hline Harrison & 152.000 & & & & \\
\hline Jackson & 85.000 & & & & \\
\hline Kanawha & 60.000 & & & & \\
\hline Lewis & 136.000 & & & & \\
\hline Lincoln & 43.000 & & & & \\
\hline Logan & 20.000 & & & & \\
\hline Marion & 45.000 & & & & \\
\hline Mcdowell & 176.000 & & & & \\
\hline Mason & 76.000 & & & & \\
\hline Mercer & 68.000 & & & & \\
\hline Mineral & 206.000 & & & & \\
\hline Mingo & 9.000 & & & & \\
\hline Monongalia & 185.000 & & & & \\
\hline Monroe & 95.000 & & & & \\
\hline Nicholas & 89.000 & & & & \\
\hline Pleasants & 133.000 & & & & \\
\hline
\end{tabular}




$\begin{array}{ll} & \\ \text { Pendleton } & 170.000 \\ \text { Pocahontas } & 125.000 \\ \text { Preston } & 187.000 \\ \text { Putnam } & 61.000 \\ \text { Raleigh } & 59.000 \\ \text { Randolph } & 154.000 \\ \text { Ritchie } & 125.000 \\ \text { Roane } & 92.000 \\ \text { Summers } & 76.000 \\ \text { Taylor } & 168.000 \\ \text { Tucker } & 173.000 \\ \text { Tyler } & 146.000 \\ \text { Upshur } & 143.000 \\ \text { Wayne } & 39.000 \\ \text { Webster } & 116.000 \\ \text { Wetzel } & 158.000 \\ \text { Wirt } & 107.000 \\ \text { Wood } & 112.000 \\ \text { Wyoming } & 42.000 \\ \text { V_Alleghany } & 119.000 \\ \text { V_Buchanan } & 32.000 \\ \text { V_Bath } & 148.000 \\ \text { V_Bland } & 75.000 \\ \text { V_Craig } & 112.000 \\ \text { V_Dickenson } & 40.000 \\ \text { V_Giles } & 93.000 \\ \text { V_Highland } & 155.000 \\ \text { V_Russell } & 48.000 \\ \text { V_Smyth } & 65.000 \\ \text { V_Tazewell } & 56.000 \\ \text { V_Wise } & 51.000 \\ \text { K_Boyd } & 52.000 \\ \text { K_Carter } & 58.000 \\ \text { K_Elliott } & 61.000 \\ \text { K_Floyd } & 28.000 \\ \text { K_Greenup } & 69.000 \\ \text { K_Johnson } & 38.000 \\ \text { K_Lawrence } & 35.000 \\ \text { K_Martin } & 19.000 \\ \text { K_Magoffin } & 44.000 \\ \text { K_Morgan } & 57.000 \\ \text { K_Pike } & 19.000 \\ \text { O_Athens } & 114.000 \\ \text { O_Belmont } & 177.000 \\ \text { O_Gallia } & 81.000 \\ \text { O_Jackson } & 97.000 \\ \text { O_Lawrence } & 66.000 \\ \text { O_Meigs } & 102.000 \\ \text { O_Monroe } & 156.000 \\ \text { O_Morgan } & 139.000 \\ \text { O_Noble } & 149.000 \\ & \\ & \end{array}$


O Scioto $\quad 92.000$

O_Vinton $\quad 111.000$

O_Washington 130.000

P_Allegheny 227.000

P_Beaver 230.000

P_Fayette $\quad 210.000$

P_Greene $\quad 183.000$

P_Somerset 243.000

P_Washington 204.000

P_Westmoreland 233.000

M Garrett 205.000

M_Allegany 306.000 


\section{APPENDIX III: ECONOMIC ANALYSIS MODEL FOR A CBTL PLANT}

\section{III.1 System requirement}

To run the economic analysis model, the following requirements must be met:

- The GAMS system must be installed in a computer. For more detailed instruction, please go to http://www.gams.com/default.htm.

- A GAMS/Cplex license file must be presented.

\section{III.2 Source code}

\$ontext

This program is used to determine the economics of a coal/biomass to liquid fuels facility within the central Appalachian region.

Programmed by Jinzhuo Wu

Division of Forestry

West Virginia University

July 25, 2009

\$offtext

\$OFFSYMLIST OFFSYMXREF

OPTION LIMCOL $=0$;

OPTION LIMROW $=0$;

OPTION SOLSLACK $=1$;

OPTION ITERLIM=5000000;

OPTION RESLIM=1000000;

\section{Sets}

I Woody biomass supply locations

/KY_Adair, KY_Allen, KY_Anderson, KY_Ballard, KY_Barren, KY_Bath, KY_Bell,

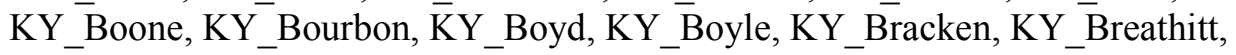

KY_Breckinridge, KY_Bullitt, KY_Butler, KY_Caldwell, KY_Calloway,

KY_Campbell, KY_Carlisle, KY_Carroll, KY_Carter, KY_Casey, KY_Christian, KY_Clark, KY_Clay, KY_Clinton, KY_Crittenden, KY_Cumberland, KY_Daviess,

KY_Edmonson, KY_Elliott, KY_Estill, KY_Fayette, KY_Fleming, KY_Floyd,

$\mathrm{KY}$ Franklin, KY Fulton, KY Gallatin, $\mathrm{KY}$ Garrard, $\mathrm{KY}$ Grant, KY Graves, KY_Grayson, KY_Green, KY_Greenup, KY_Hancock, KY_Hardin, KY_Harlan,

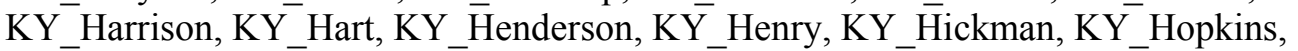
KY_Jackson, KY_Jefferson, $\bar{K} Y \_J e s s a m i n e, ~ \bar{K} Y$ Johnson, KY_Kenton, $\bar{K} Y$ Knott, KY_Knox, KY_Larue, KY_Laurel, KY_Lawrence, $\mathrm{KY}$ _Lee, $\mathrm{KY}$ _Leslie, $\mathrm{KY} \overline{\text { _}}$ Letcher,

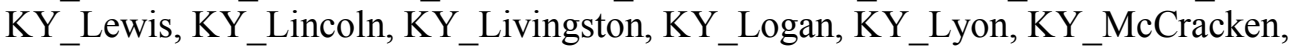
KY_McCreary, KY_McLean, KY_Madison, KY_Magoffin, KY_Marion, KY_Marshall, KY_Martin, KY_Mason, KY_Meade, KY_Menifee, KY_Mercer, KY_Metcalfe, KY_Monroe, KY_Montgomery, KY_Morgan, KY_Muhlenberg, KY_Nelson, KY_Nicholas, KY_Ohio, KY_Oldham, KY_Owen, KY_Owsley, KY_Pendleton, KY_Perry, KY_Pike, KY_Powell, KY_Pulaski, KY_Robertson, KY_Rockcastle, KY $\bar{Y}$ Rowan, $\overline{K Y}$ _Russell, KY_Scott, $\bar{K} Y \_S h e l b y, \bar{K} Y$ Simpson, KY_Spencer, KY_Taylor, KY_Todd, KY_Trigg, KY_Trimble, KY_Union, KY_Warren, KY_Washington, $\bar{K}{ }_{-}$_Wayne, $\bar{K} Y$ _Webster, KY_Whitley, KY_Wolfe, KY_Woodford, VA Accomack, VA A Albemarle, VA Alleghany, VA Amelia, VA Amherst, VA_Appomattox, VA_Arlington, VA_Augusta, VA_Bath, VA_Bedford, VA_Bland, 
VA_Botetourt, VA_Brunswick, VA_Buchanan, VA_Campbell, VA_Caroline, VA_Carroll, VA_Charles_City, VA_Charlotte, VA_Chesterfield, VA_Clarke, VA_Craig, VA_Culpeper, VA_Cumberland, VA_Dickenson, VA_Essex, VA_Fairfax, VA_Fauguier, VA_Floyd, VA_Fluvanna, VA_Franklin, VA_Frederick,

VA_Giles,VA_Gloucester,VA_Goochland,VA_Grayson,VA_Greene,VA_Greensville,

VA_Halifax, VA_Hanover, VA_Henrico, VA_Henry, VA_Highland,

VA_Isle_of_Wight, VA_James_City, VA_King_and_Queen, VA_King_George,

VA_King_William, VA_Lancaster, VA_Lee, VA_Loudoun, VA_Louisa, VA_Madison, VA_Mathews, VA_Mecklenburg, VA_Middlesex, VA_Montgomery, VA_Nelson, VA_New_Kent, VA_Northampton, VA_Northumberland, VA_Nottoway, VA_Orange, VA_Page, VA_Patrick, VA_Pittsylvania, VA_Powhatan, VA_Prince_Edward, VA_Prince_George, VA_Prince_William, VA_Pulaski, VA_Rappahannock, VA_Richmond, VA_Roanoke, VA_Rockbridge, VA_Rockingham, VA_Russell, VA_Scott, VA_Shenandoah, VA_Smyth, VA_Southampton, VA_Spotsylvania, VA_Stafford, VA_Surry, VA_Sussex, VA_Tazewell, VA_Warren,

VA_Westmoreland,VA_Wise,VA_Wythe,VA_York, PA_Adams, PA_Allegheny, PA_Armstrong, PA_Beaver, PA_Bedford, PA_Berks, PA_Blair, PA_Bradford, PA_Bucks, PA_Butler, PA_Cambria, PA_Cameron, PA_Carbon, PA_Centre, PA_Chester, PA_Clarion, PA_Clearfield, PA_Clinton, PA_Columbia, PA_Crawford, PA_Cumberland, PA_Dauphin, PA_Delaware, PA_Elk, PA_Erie, PA_Fayette, PA_Forest, PA_Franklin, PA_Fulton, PA_Greene, PA_Huntingdon, PA_Indiana, PA_Jefferson, PA_Juniata, PA_Lackawanna, PA_Lancaster, PA_Lawrence, PA_Lebanon, PA_Lehigh, PA_Luzerne, PA_Lycoming, PA_McKean, PA_Mercer, PA_Mifflin, PA_Monroe, PA_Montgomery, PA_Montour, PA_Northampton, PA Northumberland, PA Perry, PA Philadelphia, PA Pike, PA Potter, PA Schuylkill, PA_Snyder, PA_Somerset, PA_Sullivan, PA_Susquehanna, PA_Tioga, PA_Union, PA_Venango, PA_Warren, PA_Washington, PA_Wayne, PA_Westmoreland, PA_Wyoming,PA_York, MD_Allegany, MD_Anne_Arundel, MD_Baltimore, MD_Baltimore_City, MD_Calvert, MD_Caroline, $\mathrm{MD}$ _Carroll, $\mathrm{MD} \overline{\mathrm{D}}$ Cecil,

MD_Charles, MD_Dorchester, MD_Frederick, MD_Garrett, MD_Harford, MD_Howard,

MD_Kent, MD_Montgomery, MD_Prince_Georges, MD_Queen_Annes,

MD_Saint_Marys, MD_Somerset, $\mathrm{MD}$ _Talbot, MD_Washington, MD_Wicomico,

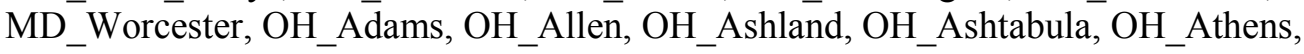

OH_Auglaize, $\mathrm{OH} \_$Belmont, $\mathrm{OH}_{-} \_$Brown, $\mathrm{OH} \_$B Butler, $\mathrm{OH} \_$Carroll, $\mathrm{OH} \_$Champaign,

OH_Clark, $\mathrm{OH} \_$Clermont, OH_Clinton, $\mathrm{OH} \_$Columbiana, $\mathrm{OH}$ _Coshocton,

$\mathrm{OH}$ _Crawford, $\mathrm{OH} \_\mathrm{Cuyahoga}, \mathrm{OH}$ _Darke, $\mathrm{OH} \_$Defiance, $\mathrm{OH}$ _Delaware, OH_Erie,

OH_Fairfield, OH_Fayette, OH_Franklin, $\mathrm{OH}_{-}$Fulton, OH_Gallia, OH_Geauga,

$\mathrm{OH} \_$Greene, $\mathrm{OH} \_$Guernsey, $\mathrm{OH} \_$Hamilton, $\mathrm{OH}$ _Hancock, $\mathrm{OH} \_$Hardin, $\mathrm{OH}$ _Harrison,

$\mathrm{OH} \_$Henry, $\mathrm{OH} \_$Highland, $\mathrm{OH} \_$Hocking, $\mathrm{OH} \_$Holmes, $\mathrm{OH} \_$Huron, $\mathrm{OH}$ Jackson,

OH_Jefferson, $\overline{\mathrm{O}} \mathrm{H} \_\mathrm{Knnox}, \mathrm{OH} \_\bar{L}$ ake, $\mathrm{OH} \_$Lawrence, $\mathrm{OH} \_$Licking, $\mathrm{OH} \_\bar{L}$ Logan,

$\mathrm{OH} \_$Lorain, $\mathrm{OH} \_$Lucas, $\mathrm{OH} \_\overline{-}$ Madison, $\mathrm{OH} \_$Mahoning, $\overline{\mathrm{OH}} \_$Marion, $\mathrm{OH} \_$Medina,

$\mathrm{OH} \_$Meigs, $\mathrm{OH}$-Mercer, $\mathrm{OH} \_$Miami, $\mathrm{OH} \_$Monroe, $\mathrm{OH} \_$Montgomery,

$\mathrm{OH} \_$Morgan, $\mathrm{O} \bar{H} \_$Morrow, $\overline{\mathrm{OH}} \_$Muskingum, $\mathrm{OH}$ _Noble, $\mathrm{OH} \_\mathrm{Ottawa}, \mathrm{OH}$-Paulding,

OH_Perry, $\mathrm{OH}$ _Pickaway, $\mathrm{OH} \_\mathrm{Pike}, \mathrm{OH} \_$Portage, $\mathrm{OH} \_$Preble, $\mathrm{OH} \_\mathrm{Putnam}$,

OH_Richland, $\overline{\mathrm{O} H}$ _Ross, $\mathrm{OH} \_\mathrm{S}$ Sandusky, $\overline{\mathrm{OH}} \_$Scioto, $\overline{\mathrm{OH}} \_$Seneca, $\overline{\mathrm{O}} \mathrm{H} \_$Shelby,

$\mathrm{OH} \_$Stark, $\mathrm{OH}$ _Summit, $\mathrm{OH}$ _Trumbull, $\mathrm{OH}$-Tuscarawas, $\mathrm{OH}$ _Union, $\overline{\mathrm{OH}}$-Van_Wert,

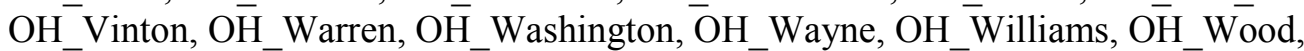

$\mathrm{OH}_{-}^{-}$Wyandot, $\overline{\mathrm{WV}}$ _Barbour, $\overline{\mathrm{WV}}$ _Boone, WV_Braxton, WV_Cabell, WV_Calhoun,

WV_Clay, WV_Doddridge, WV_Fayette, WV_Gilmer, WV_Grant, WV_Greenbrier,

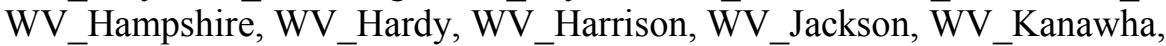
WV_Lincoln, WV_Logan, WV_Lewis, WV_Marion, WV_Marshall, 
WV_McDowell, WV_Mason, WV_Mercer, WV_Mineral, WV_Mingo, WV_Monongalia, WV_Monroe, WV_Nicholas, $\overline{W V} \overline{-}$ _Pendleton, WV_Pleasants, WV_Pocahontas, WV_Preston, WV_Putnam, WV_Raleigh, WV_Randolph, WV_Ritchie, WV_Roane, WV_Summers, WV_Taylor, WV_Tucker, WV_Tyler, WV_Upshur, WV_Wayne, WV_Webster, WV_Wetzel, WV_Wirt, WV_Wood, WV_Wyoming /

J Potential location for the CBTL plant /WV_Boone/

W(I) Switchgrass and coal supply locations /WV_Barbour, WV_Boone, WV_Braxton, WV_Cabell, WV_Calhoun, WV_Clay, WV_Doddridge, WV_Fayette, $\overline{W V}$ _Gilmer, WV_Grant, WV_Greenbrier, WV_Hampshire, WV_Hardy, WV_Harrison, WV_Jackson, $\bar{W} \mathrm{~V}$ _Kanawha, WV_Lincoln, WV_Logan, WV_Lewis, WV_Marion, WV_Marshall, WV_McDowell, WV_Mason, WV_Mercer, WV_Mineral, WV_Mingo, WV_Monongalia, WV_Monroe, WV_Nicholas, WV_Pendleton, WV_Pleasants, WV_Pocahontas, WV Preston, WV_Putnam, WV_Raleigh, WV Randolph, WV_Ritchie, WV_Roane, WV_Summers, WV_Taylor, WV_Tucker, WV_Tyler, WV_Upshur, WV_Wayne, WV_Webster, WV_Wetzel, WV_Wirt, WV_Wood, WV_Wyoming /

Feedstock Feedstock used in CBTL /Coal, Biomass/

Wood_residue Wood residue categories /Log_weton, Mill_dryton/

Avai_land Other available land for switchgrass production /Hay_land, Coal_claimed_acre/

Coal_cate Coal production and use /Coal_prod, Coal_use/

M Months of the production year /Jan, Feb, Mar, Apr, May, Jun, Jul, Aug, Sep, Oct, Nov, Dec/

$\mathrm{H}$ Logging residue handling systems /Cable-skidder, Cableskidder-chip, Grapple-skidder, Grappleskidder-chip/

G Products

/Diesel, Naphtha, Power/

Project_year_Index of the project year $/ 1 * 30 /$

SI Separated line segment index for nonlinear programming $/ 1 * 9 /$

Product Final products

/Diesel, Naphtha/ 
SPA Activities associated with switchgrass production

/Establishment, Growth, Harvest/

;

Parameter MC(H) Hourly cost of extraction machine (\$ per PMH)

/Cable-skidder $\quad 81.34$

Cableskidder-chip $\quad 81.34$

Grapple-skidder $\quad 102.72$

Grappleskidder-chip $\quad 102.72$ /;

Parameter $\operatorname{AED}(\mathrm{H}) \quad$ Average extraction distance (feet);

$\operatorname{AED}(\mathrm{H})=984$;

Parameter PL(H) Average payload size (cubic foot)

/Cable-skidder $\quad 106$

Cableskidder-chip $\quad 106$

Grapple-skidder $\quad 107.87$

Grappleskidder-chip 107.87/;

$* * * * * * * * * * * * * * * * * * * * * * * * * * * * * * * * * * * * * * * * * * * * * * * * * * * * * * * * * * * * * * * * * * * * * * * * * * * * * * * *$

*Productivities of extraction machines are from Li et al. 2006. Production economics of $\quad *$

*harvesting small-diameter hardwood stands in central Appalachia.

$* * * * * * * * * * * * * * * * * * * * * * * * * * * * * * * * * * * * * * * * * * * * * * * * * * * * * * * * * * * * * * * * * * * * * * * * * * * * * * *$

Scalar BZ Bunch size (cubic foot) /54/;

Parameter $\mathrm{PD}(\mathrm{H}) \quad$ Productivity of extraction machine (cubic foot per hour);

$\mathrm{PD}(\mathrm{H}) \$(\mathrm{ORD}(\mathrm{H}) \mathrm{LE} 2)=144.22-0.00001 * \mathrm{AED}(\mathrm{H}) * * 2+1.60 * \mathrm{PL}(\mathrm{H})-1087.54 / \mathrm{PL}(\mathrm{H})$

$-0.0003 * \mathrm{PL}(\mathrm{H}) * * 2+0.14 * \mathrm{BZ}+7.35 / \mathrm{BZ}-0.0008 * \mathrm{BZ} * \mathrm{BZ}$

$\mathrm{PD}(\mathrm{H}) \$(\mathrm{ORD}(\mathrm{H}) \mathrm{EQ} 3$ or $\mathrm{ORD}(\mathrm{H}) \mathrm{EQ} 4)=505.88-0.00004 * \mathrm{AED}(\mathrm{H}) * * 2+$ $0.005^{*} \mathrm{PL}(\mathrm{H}) * * 2$;

Parameter EC(H) Extraction cost for each system (\$ per green ton); $\mathrm{EC}(\mathrm{H})=\mathrm{MC}(\mathrm{H}) /(\mathrm{PD}(\mathrm{H}) / 35.3 * 0.77)$;

$* * * * * * * * * * * * * * * * * * * * * * * * * * * * * * * * * * * * * * * * * * * * * * * * * * * * * * * * * * * * * * * * * * * * * * * * * * * * * * *$

*Loading cost is derived by machine rate method. Loading productivity is calculated * *using Wang's model (2007). Hardwood log bucking and loading efficiency in West Virginia. * *

$* 1 \mathrm{MBF}=1.62$ cunit, 1 cunit $=4.012$ green tons.

$* * * * * * * * * * * * * * * * * * * * * * * * * * * * * * * * * * * * * * * * * * * * * * * * * * * * * * * * * * * * * * * * * * * * * * * * * * * * * * * * *$

Scalar Loader_cost Hourly cost of loader (\$ per hour) /85.96/;

Scalar Logres_D Small end diameter of slash $/ 5 /$;

Scalar NL Number of small logs or slash grappled per turn /5/;

Parameter $\mathrm{LC}(\mathrm{H}) \quad$ Average loading cost corresponding to harvesting system (\$ per ton); $\mathrm{LC}(\mathrm{H})=$ Loader_cost $/((-10.14+1.23 *$ Logres_D+1.7058*NL)*162/35.3*0.77);

*Hourly chipping/grinding costs and productivity 


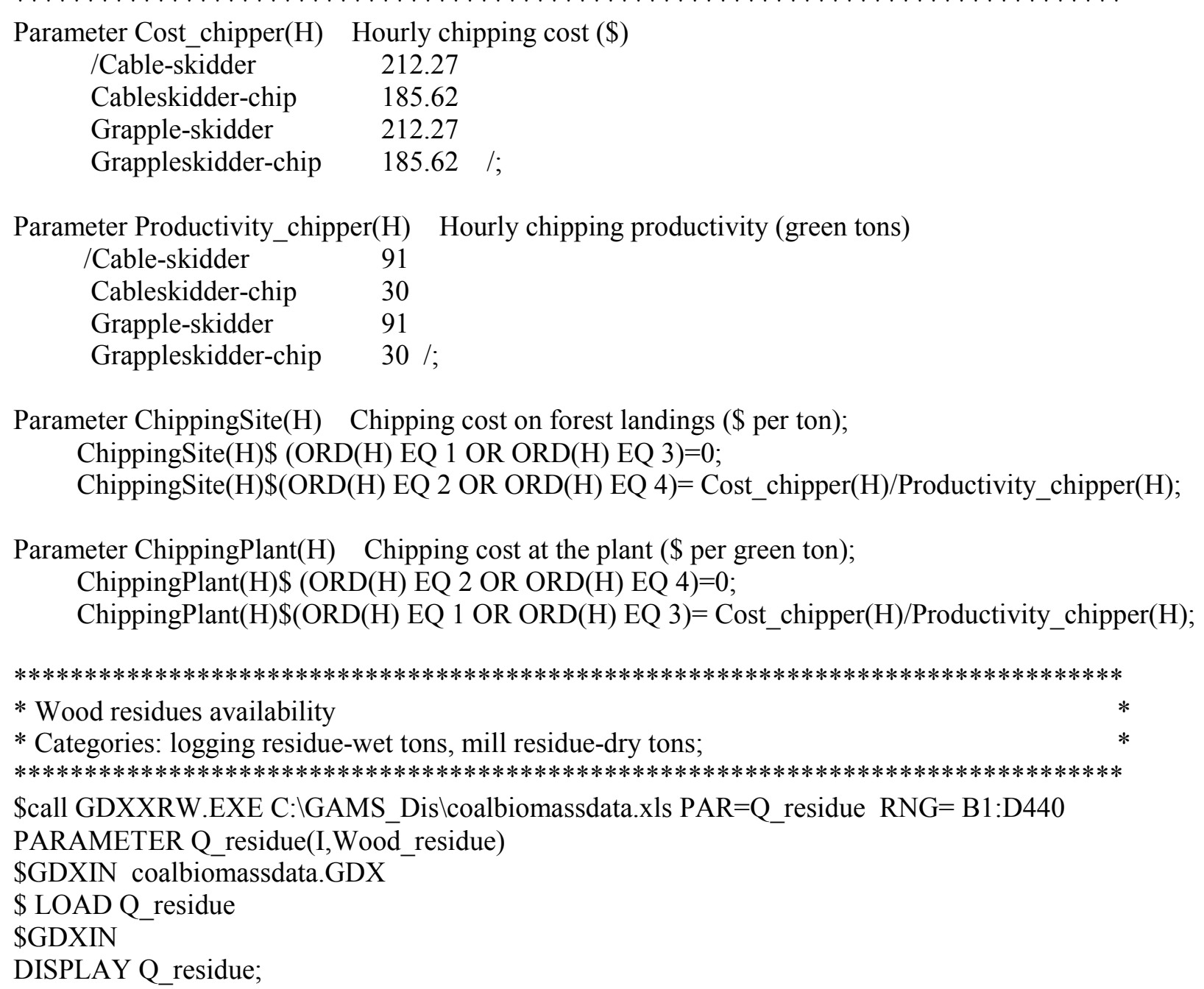

Parameter Productivity_chipper(H) Hourly chipping productivity (green tons)

$\begin{array}{lc}\text { /Cable-skidder } & 91 \\ \text { Cableskidder-chip } & 30 \\ \text { Grapple-skidder } & 91 \\ \text { Grappleskidder-chip } & 30 / \text {; }\end{array}$

Parameter ChippingSite $(\mathrm{H})$ Chipping cost on forest landings (\$ per ton); ChippingSite $(\mathrm{H}) \$(\mathrm{ORD}(\mathrm{H})$ EQ 1 OR ORD $(\mathrm{H})$ EQ 3) $=0$; ChippingSite $(\mathrm{H}) \$(\mathrm{ORD}(\mathrm{H})$ EQ 2 OR ORD(H) EQ 4)= Cost_chipper(H)/Productivity_chipper(H);

Parameter ChippingPlant $(\mathrm{H}) \quad$ Chipping cost at the plant (\$ per green ton); ChippingPlant $(\mathrm{H}) \$(\mathrm{ORD}(\mathrm{H})$ EQ 2 OR ORD $(\mathrm{H})$ EQ 4) $=0$; ChippingPlant $(\mathrm{H}) \$(\mathrm{ORD}(\mathrm{H})$ EQ 1 OR ORD $(\mathrm{H})$ EQ 3)= Cost_chipper(H)/Productivity_chipper(H);

$* * * * * * * * * * * * * * * * * * * * * * * * * * * * * * * * * * * * * * * * * * * * * * * * * * * * * * * * * * * * * * * * * * * * * * * * * * * * * * *$

* Wood residues availability

* Categories: logging residue-wet tons, mill residue-dry tons;

$* * * * * * * * * * * * * * * * * * * * * * * * * * * * * * * * * * * * * * * * * * * * * * * * * * * * * * * * * * * * * * * * * * * * * * * * * * * * * * *$

\$call GDXXRW.EXE C: IGAMS_Dis $\backslash$ coalbiomassdata.xls $\mathrm{PAR}=\mathrm{Q}$ residue $\mathrm{RNG}=\mathrm{B} 1: \mathrm{D} 440$

PARAMETER Q_residue(I,Wood_residue)

\$GDXIN coalbiomassdata.GDX

\$ LOAD Q residue

\$GDXIN

DISPLAY Q_residue;

Scalar BP Proportion of woody biomass that can be economically harvested /0.65/;

Parameter Loggingavai(I) Logging residues in tons for each supply location; Loggingavai $(\mathrm{I})=\mathrm{Q} \_$residue $\left(\mathrm{I}, " \log \_\right.$weton" $)$*BP ;

Scalar WC Woody biomass moisture content /0.43/;

Parameter ExtProp(M) Extracted proportion as a percentage of the whole year

$\begin{array}{ll}\text { /Jan } & 0.083 \\ \text { Feb } & 0.083 \\ \text { Mar } & 0.083 \\ \text { Apr } & 0.083 \\ \text { May } & 0.075 \\ \text { Jun } & 0.075 \\ \text { Jul } & 0.075 \\ \text { Aug } & 0.075 \\ \text { Sep } & 0.092 \\ \text { Oct } & 0.092 \\ \text { Nov } & 0.092\end{array}$


Dec $\quad 0.092 \quad /$

Parameter Ext_amt(I,H,M) Extraction limt per month by county in green tons;

Ext_amt $(\mathrm{I}, \mathrm{H}, \mathrm{M})=$ loggingavai $(\mathrm{I}) * \operatorname{ExtProp}(\mathrm{M})$;

$* * * * * * * * * * * * * * * * * * * * * * * * * * * * * * * * * * * * * * * * * * * * * * * * * * * * * * * * * * * * * * * * * * * * * * * * * * * * * * *$

* Proportion of available woody biomass on site

***************************************************************************************

Scalar UPS Usable proportion of logging residues at supply locations /0.95/;

Scalar UPP Usable proportion of logging residues at plants /0.99/;

Scalar Stumpage Stumpage cost of logging residues in dollar per ton /0.91/;

Scalar SC Storage cost for logging residues in the field in dollar per ton /0.00/;

**************************************************************************************

*Proportion of mill residue available

**********************************************************************************

Parameter MillProp(I) Proportion of mill residues available in each county; $\operatorname{MillProp}(\mathrm{I})=0.4$;

$* * * * * * * * * * * * * * * * * * * * * * * * * * * * * * * * * * * * * * * * * * * * * * * * * * * * * * * * * * * * * * * * * * * * * * * * * * * * * * *$

*The distance between any supply location and potential plant location

********************************************************************************

* Distance between any woody biomass supply location and the plant location

\$call GDXXRW.EXE C: $\backslash$ GAMS Dis $\backslash$ coalbiomassdata.xls PAR=dis RNG= H1:I440

PARAMETER dis(I,J)

\$GDXIN coalbiomassdata.GDX

$\$$ LOAD dis

\$GDXIN

DISPLAY dis;

* Distance between any switchgrass supply location and the plant location

\$call GDXXRW.EXE C: \GAMS_Dis $\backslash$ coalbiomassdata.xls PAR=ddis RNG=K391:L440

PARAMETER ddis(W,J)

\$GDXIN coalbiomassdata.GDX

$\$$ LOAD ddis

\$GDXIN

DISPLAY ddis;

$* * * * * * * * * * * * * * * * * * * * * * * * * * * * * * * * * * * * * * * * * * * * * * * * * * * * * * * * * * * * * * * * * * * * * * * * * * * * * * *$

* Hay lands and coal reclaimed area are used to produce switchgrass

\$call GDXXRW.EXE C:IGAMS_Dis $\backslash$ coalbiomassdata.xls PAR=Acre RNG=M391:O440

PARAMETER Acre(W,Avai_land)

\$GDXIN coalbiomassdata.GDX

$\$$ LOAD Acre

\$GDXIN

DISPLAY Acre; 
Parameter Switch_prod(Avai_land) Potential switchgrass production dry tons per acre $\begin{array}{ll}\text { /hay_land } & 6.23 \\ \text { coal_claimed_acre } & 3.0 / \text {; }\end{array}$

Parameter Switch_landprop(Avai_land) Proportion of lands used in switchgrass production $\begin{array}{ll}\text { /hay_land } & 0.1 \\ \text { coal_claimed_acre } & 0.1 / \text {; }\end{array}$

Parameter Switch_monthprop(M) Monthly production of switchgrass

$\begin{array}{ll}/ \text { Jan } & 0 \\ \text { Feb } & 0 \\ \text { Mar } & 0 \\ \text { Apr } & 0 \\ \text { May } & 0 \\ \text { Jun } & 0 \\ \text { Jul } & 1.00 \\ \text { Aug } & 1.00 \\ \text { Sep } & 1.00 \\ \text { Oct } & 0.95 \\ \text { Nov } & 0.90 \\ \text { Dec } & 0.85 / \text {; }\end{array}$

$* * * * * * * * * * * * * * * * * * * * * * * * * * * * * * * * * * * * * * * * * * * * * * * * * * * * * * * * * * * * * * * * * * * * * * * * * * * * * * *$

* Coal production and use in WV. Category: coal_prod, coal_use

*Coal production source: West Virginia Geological and Economic Survey

*http://www.wvgs.wvnet.edu/www/datastat/coalsummary/coal_summary.asp

* West Virginia coal statistics. http://www.wvminesafety.org/STATS.HTM

*The use of coal was mainly from electricity generation. The capability of large *

*coal-fired power plants in WV were considered.

$* 1$ ton coal can produce $2500 \mathrm{kWh}$ electricity.

*************************************************************************************

\$call GDXXRW.EXE C:IGAMS_Dis \coalbiomassdata.xls PAR=Q_coal RNG= R391:T440

PARAMETER Q_coal(W,coal_cate)

\$GDXIN coalbiomassdata.GDX

\$ LOAD Q_coal

\$GDXIN

DISPLAY Q_coal;

Parameter Coal_month(M) Monthly production of coal in 1000 tons

$\begin{array}{ll}\text { Jan } & 14160 \\ \text { Feb } & 12771 \\ \text { Mar } & 14899 \\ \text { Apr } & 13363 \\ \text { May } & 14228 \\ \text { Jun } & 13274 \\ \text { Jul } & 11507 \\ \text { Aug } & 14459 \\ \text { Sep } & 13370 \\ \text { Oct } & 15061 \\ \text { Nov } & 12037 \\ \text { Dec } & 12116 / \text {; }\end{array}$




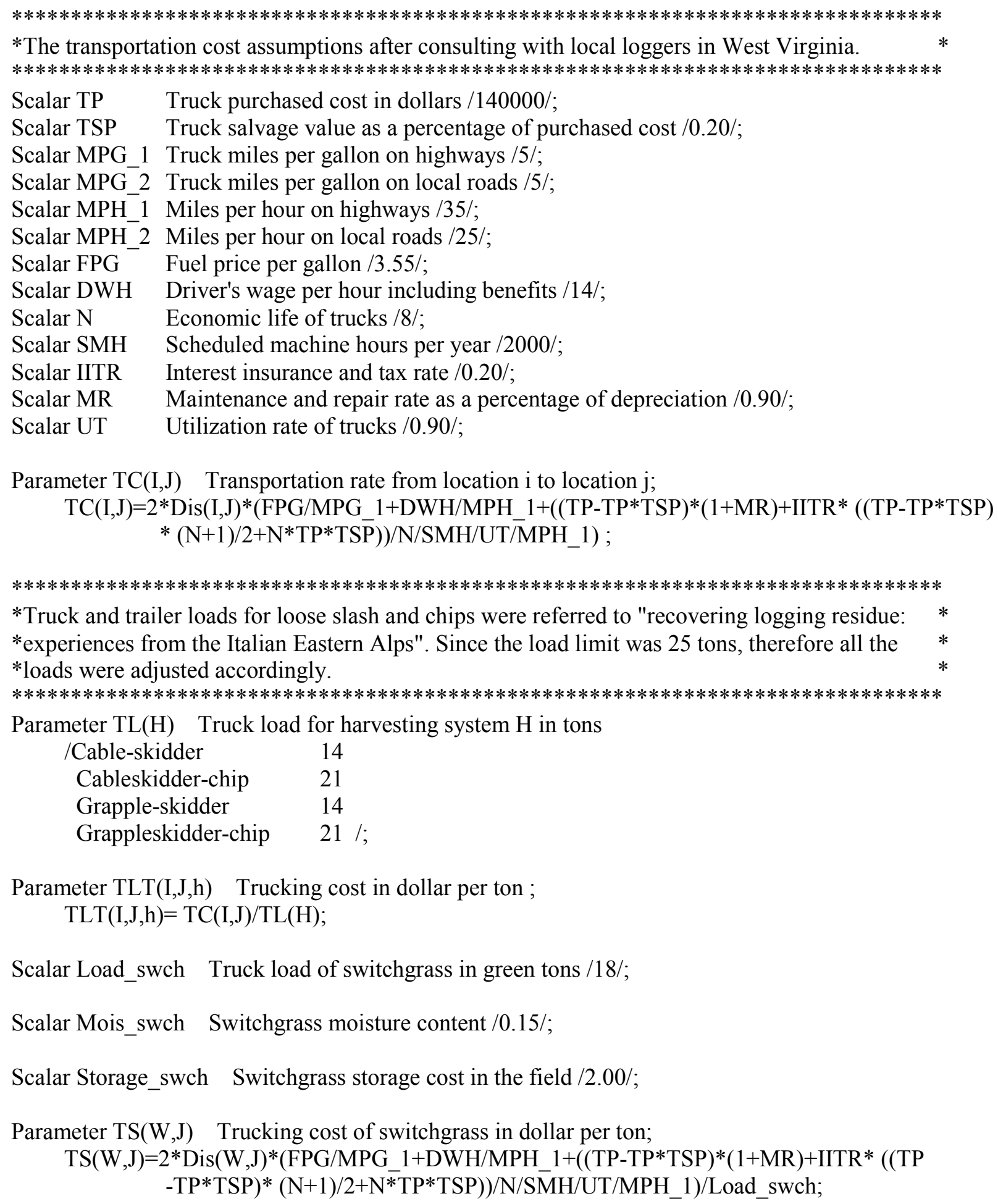

Parameter TLT(I,J,h) Trucking cost in dollar per ton ; $\mathrm{TLT}(\mathrm{I}, \mathrm{J}, \mathrm{h})=\mathrm{TC}(\mathrm{I}, \mathrm{J}) / \mathrm{TL}(\mathrm{H})$;

Scalar Load_swch Truck load of switchgrass in green tons /18/;

Scalar Mois_swch Switchgrass moisture content $/ 0.15 /$;

Scalar Storage_swch Switchgrass storage cost in the field /2.00/;

Parameter TS(W,J) Trucking cost of switchgrass in dollar per ton; $\mathrm{TS}(\mathrm{W}, \mathrm{J})=2 * \operatorname{Dis}(\mathrm{W}, \mathrm{J}) *\left(\mathrm{FPG} / \mathrm{MPG} \_1+\mathrm{DWH} / \mathrm{MPH} \_1+\left((\mathrm{TP}-\mathrm{TP} * \mathrm{TSP}) *(1+\mathrm{MR})+\mathrm{IITR}^{*}((\mathrm{TP}\right.\right.$ $\left.-\mathrm{TP} * \mathrm{TSP}) *(\mathrm{~N}+1) / 2+\mathrm{N} * \mathrm{TP} * \mathrm{TSP})) / \mathrm{N} / \mathrm{SMH} / \mathrm{UT} / \mathrm{MPH} \_1\right) / \mathrm{Load} \_s w c h$;

Scalar Switch_purcost Purchase cost of switchgrass per short ton /45.45/;

Scalar Switch_grinding Grinding cost of switchgrass \$ per green ton /1.98/; 
*Coal transport cost rate Data source: Energy Information Administration, Coal Transportation *

*Rate Database, April 2004.

*Coal purchase cost source: Energy Information Administration, Coal News and Markets

* Dec. 12, 2008. According to EIA average open market sales price of coal by state and *

*************************************************************************************

Scalar Coal_tranrate Transportation cost rate per ton mile /0.15/;

Scalar Coal_purcost Average mine-mouth price of coal per short ton /46/;

*Transportation distance within each county is assumed to be off highway.

*The transportation cost rate was calculated using Jesen's WTRANS program.

****************************************************************************************

Parameter LTC $(\mathrm{H}) \quad$ Transportation cost off highway within counties (\$ per ton.mile);

$\mathrm{LTC}(\mathrm{H})=2 *(\mathrm{FPG} / \mathrm{MPG} 2+\mathrm{DWH} / \mathrm{MPH} 2+(\mathrm{TP}-\mathrm{TP} * \mathrm{TSP}) *(1+\mathrm{MR})+\mathrm{IITR} *$

$\left.((\mathrm{TP}-\mathrm{TP} * \mathrm{TSP}) *(\mathrm{~N}+1) / 2+\mathrm{N} * \mathrm{TP} * \mathrm{TSP})) / \mathrm{N} / \mathrm{SMH} / \mathrm{UT} / \mathrm{MPH} \_2\right) / \mathrm{TL}(\mathrm{h})$;

Parameter Swch_ltc Switchgrass off highway transportation cost rate;

Swch_ltc $=\overline{2} *\left(\mathrm{FPG} / \mathrm{MPG} \_2+\mathrm{DWH} / \mathrm{MPH} \_2+((\mathrm{TP}-\mathrm{TP} * \mathrm{TSP}) *(1+\mathrm{MR})+\mathrm{IITR} *\right.$

$((\mathrm{TP}-\mathrm{TP} * \mathrm{TSP}) *(\mathrm{~N}+1) / 2+\mathrm{N} * \mathrm{TP} * \mathrm{TSP})) / \mathrm{N} / \mathrm{SMH} / \mathrm{UT} / \mathrm{MPH}$ 2)/Load_swch ;

Parameter FC(SI) Coefficients of linearized local transportation turnover function (Woody biomass)

$\begin{array}{ll}/ 1 & 1.583 \\ 2 & 3.322 \\ 3 & 4.738 \\ 4 & 6.474 \\ 5 & 9.156 \\ 6 & 11.856 \\ 7 & 14.04 \\ 8 & 15.925 \\ 9 & 18.377 /\end{array}$

Parameter Swch_FC(SI) Coefficients of linearized local transportation turnover function (Switchgrass)

$/ 1 \quad 2.11$

$2 \quad 4.43$

$3 \quad 6.32$

$4 \quad 8.64$

$5 \quad 12.22$

$6 \quad 15.82$

$7 \quad 18.73$

$8 \quad 21.25$

$925.01 \quad /$

Parameter B(SI) Right hand side of the constraints for separated variable in linearized function

$\begin{array}{ll}/ 1 & 1000 \\ 2 & 2000 \\ 3 & 2000 \\ 4 & 5000 \\ 5 & 10000 \\ 6 & 10000 \\ 7 & 10000\end{array}$




$\begin{array}{ll}8 & 10000 \\ 9 & 25000 /\end{array}$

Scalar Millcost Cost of mill residue ( $\$$ per green ton) /20/;

Scalar Mill_load Load of mill residue in green tons $/ 21 /$;

Parameter Milltrancost Cost of delivering mill residues (\$ per ton mile); Milltrancost=2*(FPG/MPG_1+DWH/MPH_1+((TP-TP*TSP $) *(1+\mathrm{MR})+\mathrm{IITR} *$ $\left.((\mathrm{TP}-\mathrm{TP} * \mathrm{TSP}) *(\mathrm{~N}+1) / 2+\overline{\mathrm{N}} * \mathrm{TP} * \mathrm{TSP})) / \mathrm{N} / \mathrm{SMH} / \mathrm{UT} / \mathrm{MPH} \_1\right) / \mathrm{Mill} \_l o a d ;$

Scalar TLoss Dry matter loss due to transportation /0.02/;

* Coal/biomass to liquid fuels plant assumption

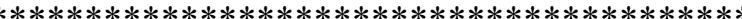

Parameter Feedstock_needed_ref(Feedstock) Feedstock needed per day in the reference /Coal 4589

Biomass 510/;

Scalar Day Working days per month $/ 29 /$;

Parameter N Plant life ; $\mathrm{N}=\mathrm{CARD}$ (project_year);

Scalar FT Federal tax applied to ethanol facility /0.39/;

Scalar Equity_prop Proportion of equity in the total investment /0.4/;

Scalar Re Cost of equity $/ 0.15 /$;

Scalar Rd Cost of debt /0.08/;

Parameter WACC Weighted average cost of capital; WACC=Equity_prop*Re+(1-Equity_prop)*Rd*(1-FT);

* Compute amortization factor

Scalar $r$ Inflation rate $/ 0.02 /$;

Scalar p Construction period (years) $/ 3 /$;

Scalar mf Maintenance factor $/ 1.04 /$;

Parameter qq;

$\mathrm{qq}=(1+\mathrm{WACC}) *(1+\mathrm{r})$;

Parameter PVI Amortization factor; $\mathrm{PVI}=1 /\left((\mathrm{qq} * *(\mathrm{~N}+\mathrm{p})-1) /\left((\mathrm{qq}-1) * \mathrm{qq}^{* *}(\mathrm{~N}+\mathrm{p})\right)-(\mathrm{qq} * * \mathrm{p}-1) /((\mathrm{qq}-1) * \mathrm{qq} * * \mathrm{p})\right)^{*} \mathrm{mf} ;$ Display PVI;

Scalar TPC_ref Total project investment in the reference 2005 dollar (\$) /1051000000/;

Scalar Fixed_OM_ref Annual operating and maintenance cost 2005 dollar (\$)/27000000/; 
Scalar Var_OM_ref Variable operation and maintenance cost (\$) /35000000/;

Parameter Yield1(Product) Proportion of products produced based on total liquid fuels
/Diesel
0.6818

Naphtha

$0.3182 /$;

Parameter Yield3(Product) Proportion of products produced based on FT diesel equivalent

$\begin{array}{ll}\text { Diesel } & 0.75 \\ \text { Naphtha } & 0.35 /\end{array}$

Parameter Yield2(Feedstock) Liquid fuels from feedstock (bbls per ton of feedstock)

$\begin{array}{ll}\text { /Coal } & 2.25 \\ \text { Biomass } & 1.32 / \text {; }\end{array}$

Parameter Daily_prod_ref Daily production in the reference barrels per day;

Daily_prod_ref=Sum(Feedstock,Yield2(Feedstock)*Feedstock_needed_ref(Feedstock));

$* * * * * * * * * * * * * * * * * * * * * * * * * * * * * * * * * * * * * * * * * * * * * * * * * * * * * * * * * * * * * * * * * * * * * * * * * * * * * * *$
$* \mathrm{Pl}$ lant capacity
$* * * * * * * * * * * * * * * * * * * * * * * * * * * * * * * * * * * * * * * * * * * * * * * * * * * * * * * * * * * * * * * * * * * * * * * * * * * * * * * * * *$

Parameter Feedstock_needed(Feedstock) Feedstock needed per day

/Coal $\quad 16110$

Biomass $2843 \quad /$;

Parameter Daily_prod Daily production (barrels);

Daily_prod=Sum(Feedstock,YYield2(Feedstock)*Feedstock_needed(Feedstock));

Scalar M_S_05_Marshall \& Swift all industry equipment cost index in 2005 /1244.5/;

Scalar M_S_07 Marshall \& Swift all industry equipment cost index in 2007 /1373.3/;

Scalar GPD_05 Gross national product deflator index in 2005/114.523/;

Scalar GPD_07 Gross national product deflator index in $2007 / 120.737 /$;

Scalar Exponent Exponent indicator $/ 0.7 /$;

$* * * * * * * * * * * * * * * * * * * * * * * * * * * * * * * * * * * * * * * * * * * * * * * * * * * * * * * * * * * * * * * * * * * * * * * * * * * * * * * *$

*Extra capital and OM cost were based on: Gray et al. 2007. Increasing security and reducing *

*carbon emission of the U.S. transportation sector: A transformational role for coal with *

*biomass. US Department of Energy, National Energy Technology Laboratory. *

$* * * * * * * * * * * * * * * * * * * * * * * * * * * * * * * * * * * * * * * * * * * * * * * * * * * * * * * * * * * * * * * * * * * * * * * * * * * * * * * *$

Parameter Extra_TPC Extra capital cost due to different coal biomass ratio;

Extra_TPC $=4000000 *$ (Feedstock_needed("Biomass")/Sum(Feedstock, Feedstock_needed(Feedstock))-0.10)/0.05;

Parameter Extra_OM Extra operation and maintenance cost due to different coal biomass ratio; Extra_OM=1000000*(Feedstock_needed("Biomass")/Sum(Feedstock, Feedstock_needed(Feedstock))-0.10)/0.05; 
Parameter TPC Total capital cost;

$\mathrm{TPC}=\left(\mathrm{TPC} \_r e f+e x t r a \_T P C\right) *\left(\mathrm{M} \_S \_07 / \mathrm{M} \_S \_05\right) *\left(D a i l y \_p r o d / D a i l y \_p r o d \_r e f\right) * * 0.7$;

Parameter OM Operation and maintenance cost $(\$)$;

$\mathrm{OM}=($ Fixed_OM_ref*(Daily_prod/Daily_prod_ref)**0.65 +(Var_OM_ref+extra_OM)

*Daily_prod/Daily_prod_ref)*(GPD_07/GPD_05);

Display Extra_TPC, Extra_OM, TPC, OM;

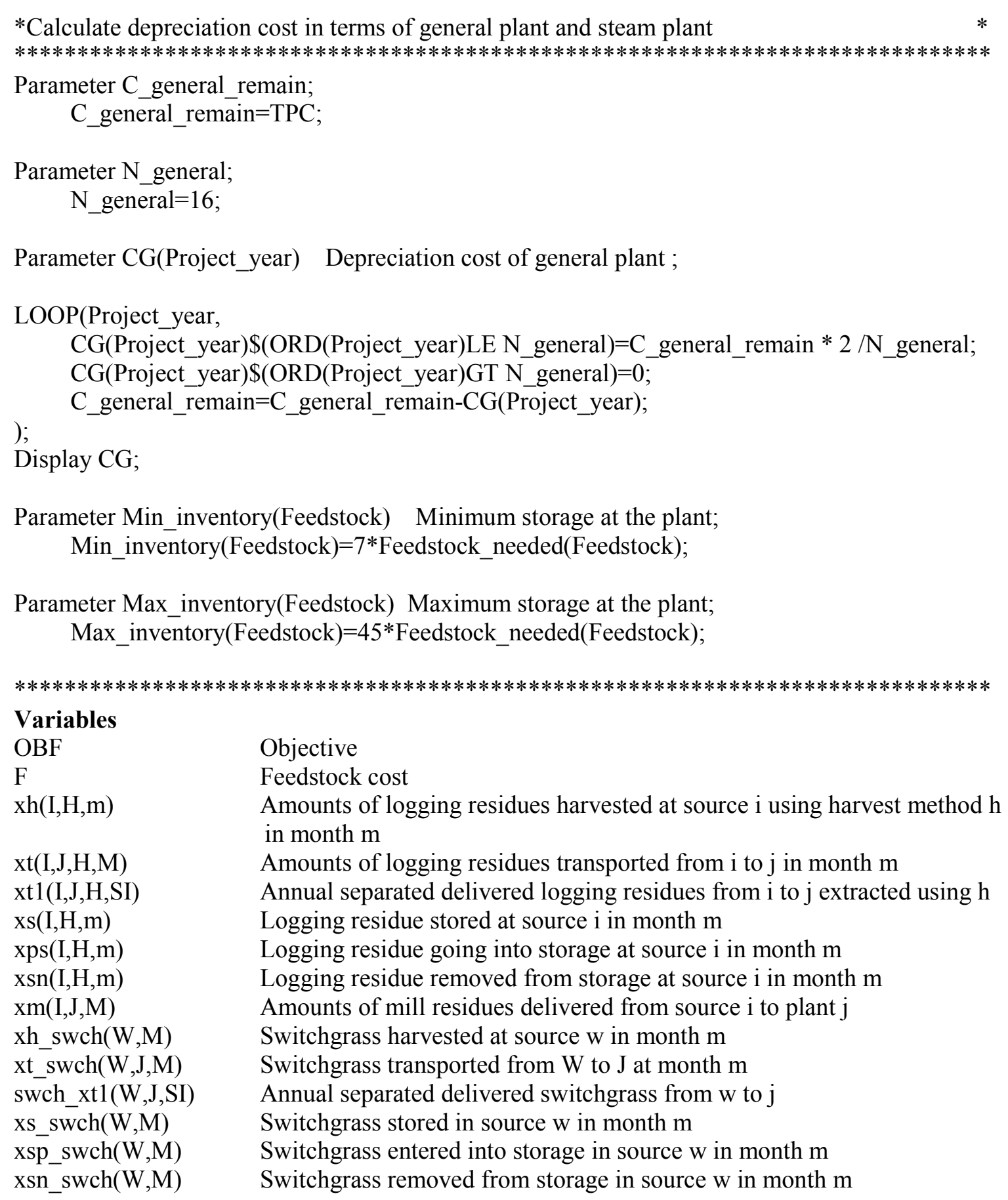


xt_co(w,J,M)

$\operatorname{Beta}(\mathrm{J})$

Alfa(I,H)

Q(J,Product,M)

SS(J,Feedstock,M)

SP(J,Feedstock,M)
Coal delivered from location $\mathrm{w}$ to plant $\mathrm{j}$ in month $\mathrm{m}$

Binary variable for plant at location $\mathrm{j}$

Binary variable for harvesting method

Quantity of liquid fuels produced at plant $\mathrm{j}$ in month $\mathrm{m}$

Quantity of feedstock stored at plant $j$ in month $m$

Quantity of feedstock processed at plant $\mathrm{j}$ in month $\mathrm{m}$

Delivered_feedstock(J,Feedstock,M)

Quantity of feedstock delivered to plant $\mathrm{j}$ in month $\mathrm{m}$;

Positive Variables xh, xt, xt1, xs, xps, xsn, xm, Q, SS, SP, xh_swch, xt_swch, xs_swch,

Binary Variables Beta, Alfa;

\author{
Equations \\ Obj \\ Feedstock func \\ Objective function \\ Logresidue $(\mathrm{I}, \mathrm{H})$ \\ Feedstock function \\ Ext_limt_1(I,H,M) \\ Ext_limt_2(I,H,M) \\ Logging residues available at source $\mathrm{i}$ \\ Extraction limit of logging residues at source $\mathrm{i}$ in month $\mathrm{m}$ \\ Extraction limit by cable skidder \\ Ext_limt_3(I,H,M) \\ Ext_limt_4(I,H,M) \\ Extraction limit by grapple skidder \\ Trans $(\mathrm{I}, \overline{\mathrm{J}}, \mathrm{H})$ \\ Tran_con1(I,J,H,SI) \\ Extraction limit by forwarder \\ Constraint 1 for woody biomass within county transportation \\ Storage1 $(\mathrm{I}, \mathrm{H}, \mathrm{M})$ \\ Storage2(I) \\ Storage3(I,M) \\ Milltrant(I) \\ Constraint 2 for woody biomass within county transportation \\ Woody biomass supply balance using system $\mathrm{h}$ at source $\mathrm{i}$ in month $\mathrm{m}$ \\ Woody biomass supply balance at source $\mathrm{i}$ \\ Woody biomass storage system at source $i$ in month $\mathrm{m}$ \\ Amounts of Mill residues purchased at source i \\ Swch_Trans(W,J) Constraint 1 for switchgrass within county transportation \\ Swch_Tran_con $1(\mathrm{~W}, \mathrm{~J}, \mathrm{SI})$ \\ Constraint 2 for switchgrass within county transportation \\ Switchgrass(W,M) Switchgrass available at source $\mathrm{w}$ in month $\mathrm{m}$ \\ Switchgrass_st $1(\mathrm{~W}, \mathrm{M})$ Constraint 1 for switchgrass storage balance at source $\mathrm{w}$ in month $\mathrm{m}$ \\ Switchgrass_st2(W) Constraint 2 for switchgrass storage balance at source $\mathrm{w}$ \\ Switchgrass_st3(W,M) Constraint 3 for switchgrass storage balance at source w in month $\mathrm{m}$ \\ Coal_tran1 $(\overline{\mathrm{W}}, \mathrm{M}) \quad$ Constraint for coal transportation 1 \\ MXplant \\ Maximum of one plant \\ MXHarvest(I) \\ One(I) \\ $\mathrm{T} 1(\mathrm{~J}, \mathrm{M})$ \\ T2(J,M) \\ Maximum of harvesting system \\ Assign one harvesting system \\ Biomass delivered \\ P1(J,Feedstock,M) \\ P2(J,Feedstock,M) \\ Coal delivered \\ P3(J,Feedstock,M) \\ Constraint 1 for plant processing \\ Constraint 2 for plant processing \\ Constraint 3 for plant processing \\ P4(J,Feedstock,M) \\ Constraint 4 for plant processing \\ Conversion(J,Product,M) Coal to liquid conversion \\ ; \\ Obj.. $\quad$ OBF $=\mathrm{E}=\mathrm{F}+\mathrm{OM}+\mathrm{TPC} * \mathrm{PVI}$; \\ Feedstock_func.. $\quad$ F- $(\operatorname{sum}((\mathrm{I}, \mathrm{H}, \mathrm{M}),(\mathrm{EC}(\mathrm{H})+$ stumpage $) * \mathrm{xh}(\mathrm{I}, \mathrm{H}, \mathrm{M}))+$ \\ $\operatorname{sum}((\mathrm{I}, \mathrm{H}, \mathrm{M}), \mathrm{SC} * \operatorname{xps}(\mathrm{I}, \mathrm{H}, \mathrm{m}))+\operatorname{sum}((\mathrm{I}, \mathrm{J}, \mathrm{H}, \mathrm{M}),($ ChippingSite $(\mathrm{H})+$ \\ $\left.\mathrm{LC}(\mathrm{H})+\mathrm{TLT}(\mathrm{I}, \mathrm{J}, \mathrm{H})+\mathrm{ChippingPlant}(\mathrm{H}))^{*} \mathrm{xt}(\mathrm{I}, \mathrm{J}, \mathrm{H}, \mathrm{M})\right)+$
}




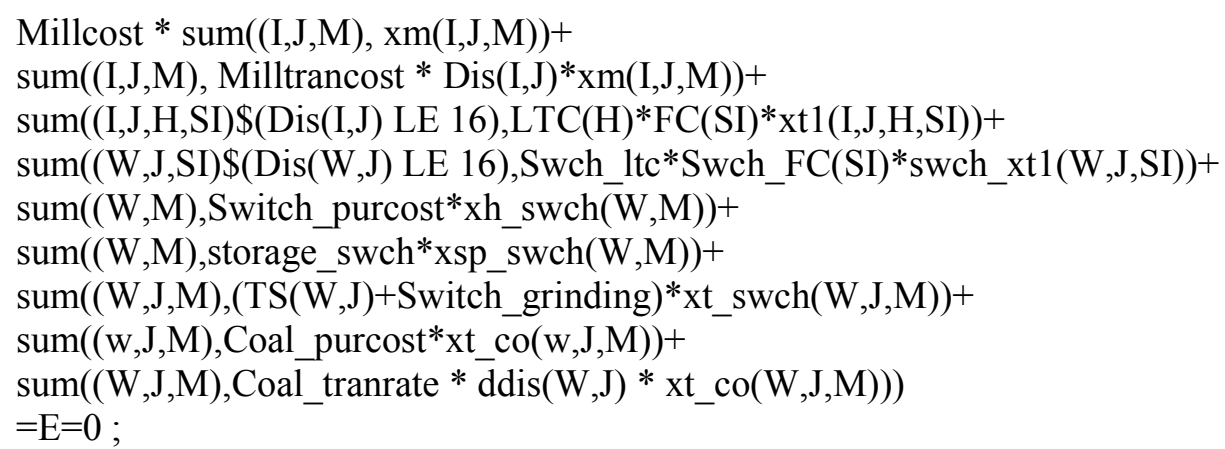

Logresidue(I,H).. $\operatorname{sum}(\mathrm{M}, \mathrm{xh}(\mathrm{I}, \mathrm{H}, \mathrm{M}))-\mathrm{Alfa}(\mathrm{I}, \mathrm{H}) *$ Loggingavai $(\mathrm{I})=\mathrm{L}=0$;

Ext_limt_1(I,H,M).. $\overline{x h}(\mathrm{I}, \mathrm{H}, \mathrm{M})-\mathrm{Ext} \_a m t(\mathrm{I}, \mathrm{H}, \mathrm{M})=\mathrm{L}=0$;

Ext_limt_2(I,H,M)\$(ord(H) LE 2).. $\mathrm{xh}(\mathrm{I}, \mathrm{H}, \mathrm{M})-20 * 180 * \mathrm{PD}(\mathrm{H}) * 0.02=\mathrm{L}=0$;

Ext_limt_3(I,H,M)\$(ord(H) EQ 3 or ord(H) EQ 4).. $\mathrm{xh}(\mathrm{I}, \mathrm{H}, \mathrm{M})-20 * 192 * \mathrm{PD}(\mathrm{H}) * 0.02=\mathrm{L}=0$;

Ext_limt 4(I,H,M)\$(ord(H) GE 5).. $\overline{\mathrm{xh}}(\mathrm{I}, \mathrm{H}, \mathrm{M})-20 * 120 * \mathrm{PD}(\mathrm{H}) * 0.02=\mathrm{L}=0$;

$\operatorname{Trans}(\mathrm{I}, \mathrm{J}, \mathrm{H})$..

$\operatorname{Sum}(\operatorname{SI}, x t 1(\mathrm{I}, \mathrm{J}, \mathrm{H}, \mathrm{SI}))-\operatorname{sum}(\mathrm{M}, \mathrm{xt}(\mathrm{I}, \mathrm{J}, \mathrm{H}, \mathrm{M}))=\mathrm{E}=0$;

Tran_con1(I,J,H,SI).. $\mathrm{xt} 1(\mathrm{I}, \mathrm{J}, \mathrm{H}, \mathrm{SI})=\mathrm{L}=\mathrm{B}(\mathrm{SI})$;

Storage1(I,H,M).. $\mathrm{xh}(\mathrm{I}, \mathrm{H}, \mathrm{M})+\mathrm{UPS} * \mathrm{xs}(\mathrm{I}, \mathrm{H}, \mathrm{M}-1)-\operatorname{sum}(\mathrm{J}, \mathrm{xt}(\mathrm{I}, \mathrm{J}, \mathrm{H}, \mathrm{M}))-\mathrm{xs}(\mathrm{I}, \mathrm{H}, \mathrm{M})=\mathrm{E}=0$;

Storage2(I).. $\operatorname{sum}((\mathrm{H}, \mathrm{M}), \mathrm{xh}(\mathrm{I}, \mathrm{H}, \mathrm{M}))-\operatorname{sum}((\mathrm{J}, \mathrm{H}, \mathrm{M}), \mathrm{xt}(\mathrm{I}, \mathrm{J}, \mathrm{H}, \mathrm{M}))-(1-\mathrm{UPS})^{*} \operatorname{sum}((\mathrm{H}, \mathrm{M}), \mathrm{xs}(\mathrm{I}, \mathrm{H}, \mathrm{M}))=\mathrm{E}=0$;

Storage3(I,M).. $\operatorname{sum}(\mathrm{H}, \mathrm{xh}(\mathrm{I}, \mathrm{H}, \mathrm{M}))-\operatorname{sum}(\mathrm{H}, \mathrm{xps}(\mathrm{I}, \mathrm{H}, \mathrm{M}))+\operatorname{sum}(\mathrm{H}, \mathrm{xsn}(\mathrm{I}, \mathrm{H}, \mathrm{M}))-\operatorname{sum}((\mathrm{J}, \mathrm{H}), \mathrm{xt}(\mathrm{I}, \mathrm{J}, \mathrm{H}, \mathrm{M}))=\mathrm{E}=0$;

Swch_Trans(W,J)..

$\operatorname{Sum}(\mathrm{SI}, \mathrm{swch}$ xt1(W,J,SI) $)$-sum(M,xt_swch $(\mathrm{W}, \mathrm{J}, \mathrm{M}))=\mathrm{E}=0$;

Swch_Tran_con1(W,J,SI).. swch_xt1(W,J,SI) $=\mathrm{L}=\mathrm{B}(\mathrm{SI})$;

Switchgrass(W,M).. xh_swch(W,M)-sum(Avai_land,Switch_monthprop(M)* Switch_prod(Avai_land) $/(1-$ Mois_swch)*Switch_landprop(Avai_land)*Acre $($ W,Avai_land $))=\mathrm{L}=0$; 
Switchgrass_st1(W,M)..

xh_swch(W,M)+ UPS*xs_swch(W,M-1)-sum(J,xt_swch(W,J,M $))-x s \_s w c h(W, M)=E=0$;

Switchgrass_st2(W)..

$\operatorname{sum}\left(\mathrm{M}, \mathrm{xh} \_\operatorname{swch}(\mathrm{W}, \mathrm{M})\right)-\operatorname{sum}\left((\mathrm{J}, \mathrm{M}), \mathrm{xt} \_\operatorname{swch}(\mathrm{W}, \mathrm{J}, \mathrm{M})\right)-(1-\mathrm{UPS})^{*} \operatorname{sum}\left(\mathrm{M}, \mathrm{xs} \_\operatorname{swch}(\mathrm{W}, \mathrm{M})\right)=\mathrm{E}=0$;

Switchgrass_st3(W,M)..

xh_Swch(W,M)-xsp_swch(W,M)+xsn_swch(W,M)-sum $\left(\mathrm{J}, \mathrm{xt} \_\operatorname{swch}(\mathrm{W}, \mathrm{J}, \mathrm{M})\right)=\mathrm{E}=0$;

Milltrant(I)..

$\operatorname{sum}((\mathrm{J}, \mathrm{M}), \mathrm{xm}(\mathrm{I}, \mathrm{J}, \mathrm{M}))-\operatorname{MillProp}(\mathrm{I}) * \mathrm{Q} \_$residue $(\mathrm{I}, "$ mill_dryton" $) /(1-\mathrm{WC})=\mathrm{L}=0$;

Coal_tran1(W,M)..

$\operatorname{sum}\left((\mathrm{J}), \mathrm{xt} \_c o(\mathrm{w}, \mathrm{J}, \mathrm{M})\right)-1000 *\left(\mathrm{Q} \_\right.$coal $\left.\left(\mathrm{W}, " \mathrm{coal} \_p r o d "\right)-\mathrm{Q} \_c o a l\left(\mathrm{~W}, " \mathrm{coal} \_u s e "\right)\right) / 12=\mathrm{L}=0$;

MXplant..

$\operatorname{sum}(\mathrm{J}, \operatorname{Beta}(\mathrm{J}))=\mathrm{E}=1$;

MXHarvest(I)..

One(I)..

$\operatorname{sum}(\mathrm{H}, \operatorname{Alfa}(\mathrm{I}, \mathrm{H}))=\mathrm{E}=1$;

Alfa(I, "Cable-skidder")=E=1;

$\mathrm{T} 1(\mathrm{~J}, \mathrm{M})$..

$(\operatorname{sum}((\mathrm{I}, \mathrm{H}), \mathrm{xt}(\mathrm{I}, \mathrm{J}, \mathrm{H}, \mathrm{M})) *(1-\mathrm{Tl}$ loss $)+\operatorname{sum}(\mathrm{I}, \mathrm{xm}(\mathrm{I}, \mathrm{J}, \mathrm{M}))) *(1-\mathrm{WC})+\operatorname{sum}\left(\mathrm{W}, \mathrm{xt} \_\mathrm{swch}(\mathrm{W}, \mathrm{J}, \mathrm{M})\right)$

*(1-Mois_swch)-Delivered_feedstock(J,"Biomass",M) =E=0;

$\mathrm{T} 2(\mathrm{~J}, \mathrm{M})$.

$\operatorname{sum}\left(\mathrm{W}, \mathrm{xt} \_c o(\mathrm{w}, \mathrm{J}, \mathrm{M})\right)$-Delivered_feedstock $(\mathrm{J}, \mathrm{CCoal}$ ",M $)=\mathrm{E}=0$;

P1(J,Feedstock,M)..

Delivered_feedstock(J,Feedstock,M)+UPP*SS(J,Feedstock, M-1)-SP(J,Feedstock,M)

$-\mathrm{SS}(\mathrm{J}$, Feedstock,M $)=\mathrm{E}=0$;

P2(J,Feedstock,M)..

$\mathrm{SS}(\mathrm{J}$, Feedstock,M)-MIN_inventory(Feedstock) $* \operatorname{Beta}(\mathrm{J})=\mathrm{G}=0$;

P3(J,Feedstock,M)..

SP(J,Feedstock,M)-Day*Feedstock_needed(Feedstock $)=\mathrm{G}=0$;

P4(J,Feedstock,M)..

$\mathrm{SS}(\mathrm{J}$, Feedstock,M)-MAX_inventory(Feedstock $) * \operatorname{Beta}(\mathrm{J})=\mathrm{L}=0$;

Conversion(J,Product,M)..

$\mathrm{Q}(\mathrm{J}$, product,M)-Yield1(Product) * Sum(Feedstock, Yield2(Feedstock) * SP(J,Feedstock,M))

$=\mathrm{E}=0$;

Model Bioplant /all/;

Solve Bioplant min OBF using MIP;

Option solprint $=$ off; 
Parameter RSP Required selling price of F-T diesel (dollar per barrel);

$\mathrm{RSP}=\mathrm{OBF} .1 / \operatorname{sum}((\mathrm{J}, \mathrm{M}),(\mathrm{Q} .1(\mathrm{~J}, " \mathrm{Diesel}$ ",M $)+0.75$ * Q.1(J,"Naphtha",M)));

Display RSP;

Parameter Switchgrass_harvest Switchgrass harvested (metric tons);

Switchgrass_harvest $=$ sum $((\mathrm{W}, \mathrm{J}, \mathrm{M}), \mathrm{xt}$ _swch.1(W,J,M $)) / 1.1$;

Display switchgrass_harvest;

Parameter Woody_harvest, Mill_resi Woody biomass delivered (metric tons);

Woody_harvest=sum((I,J,H,M),xt.1(I,J,H,M))/1.1;

Mill_resi=sum $((\mathrm{I}, \mathrm{J}, \mathrm{M}), \mathrm{xm} .1(\mathrm{I}, \mathrm{J}, \mathrm{M})) / 1.1$;

Display Woody_harvest, Mill_resi;

Parameter FCM Fuel consumption during transportation of biomass (gallons);

$\mathrm{FCM}=(\operatorname{Sum}((\mathrm{I}, \mathrm{J}, \mathrm{H}, \mathrm{M}), 2 * \operatorname{Dis}(\mathrm{I}, \mathrm{J}) * \mathrm{xt} . \mathrm{L}(\mathrm{I}, \mathrm{J}, \mathrm{H}, \mathrm{M}) / \mathrm{TL}(\mathrm{H}))+\operatorname{Sum}((\mathrm{I}, \mathrm{J}, \mathrm{M}), 2 * \operatorname{Dis}(\mathrm{I}, \mathrm{J}) * \mathrm{xm} . \mathrm{L}(\mathrm{I}, \mathrm{J}, \mathrm{M})$

/Mill_load $)+\operatorname{Sum}\left((\mathrm{W}, \mathrm{J}, \mathrm{M}), 2 * \operatorname{Dis}(\mathrm{W}, \mathrm{J}) * \mathrm{xt} \_\right.$swch.L(W,J,M $) /$Load_swch $\left.)\right) / M P G \_1$;

Display FCM;

Parameter Coalcost, Biomasscost, Annutpc, Omm F-T diesel cost by category;

Coalcost $=\operatorname{sum}\left((\mathrm{w}, \mathrm{J}, \mathrm{M}),(\right.$ Coal_tranrate $* \operatorname{ddis}(\mathrm{W}, \mathrm{J})+$ Coal_purcost $) * \mathrm{xt} \_$co.l(w,J,M $\left.)\right)$ /sum((J,M),(Q.1(J,"Diesel",M)+ 0.75 * Q.1(J,"Naphtha",M)));

Biomasscost $=\left(\right.$ F.1-sum $\left((\mathrm{w}, \mathrm{J}, \mathrm{M}),(\right.$ Coal_tranrate * ddis $(\mathrm{W}, \mathrm{J})+$ Coal_purcost $\left.\left.) * x t \_c o .1(\mathrm{w}, \mathrm{J}, \mathrm{M})\right)\right)$ /sum((J,M),(Q.1(J,"Diesel",M)+ $0.75 *$ Q.1(J,"Naphtha",M)));

Annutpc=TPC*PVI/sum((J,M),(Q.1(J,"Diesel",M)+ 0.75 * Q.1(J,"Naphtha",M)));

Omm=OM/sum((J,M),(Q.1(J,"Diesel",M)+ $0.75 *$ Q.1(J,"Naphtha",M)));

Display Coalcost, Biomasscost, Omm, Annutpc;

$* * * * * * * * * * * * * * * * * * * * * * * * * * * * * * * * * * * * * * * * * * * * * * * * * * * * * * * * * * * * * * * * * * * * * * * * * * * * * * *$

*Biomass supply by county

$* * * * * * * * * * * * * * * * * * * * * * * * * * * * * * * * * * * * * * * * * * * * * * * * * * * * * * * * * * * * * * * * * * * * * * * * * * * * * * *$

Parameter County_log(I,M), County_mill(I,M), County_swt(W,M) Biomass delivered by county by month (metric tons);

$$
\begin{aligned}
& \text { County_log(I,M)=sum }((\mathrm{J}, \mathrm{H}), \mathrm{xt} .1(\mathrm{I}, \mathrm{J}, \mathrm{H}, \mathrm{M})) / 1.1 ; \\
& \text { County_mill(I,M)=sum }((\mathrm{J}), \mathrm{xm} .1(\mathrm{I}, \mathrm{J}, \mathrm{M})) / 1.1 ; \\
& \text { County_swt }(\mathrm{W}, \mathrm{M})=\operatorname{sum}((\mathrm{J}), \mathrm{xt} \text { _swch.1(W,J,M })) / 1.1 ;
\end{aligned}
$$

Display County_log, County_mill, County_swt;

$*$ This part is used to export the delivered feedstock to excel files 


\begin{tabular}{|c|c|c|}
\hline \multicolumn{3}{|c|}{ Execute_unload "results1.gdx" xt.1 } \\
\hline \multicolumn{3}{|c|}{ Execute_unload "results2.gdx" xm.1 } \\
\hline \multicolumn{3}{|c|}{ Execute ' $\mathrm{gdxx}$ rw.exe results $2 . \mathrm{gdx} \mathrm{o}=$ results $2 . \mathrm{xls}$ var $=\mathrm{xn}$} \\
\hline \multicolumn{3}{|c|}{ Execute unload "results3.gdx" xt co.1 } \\
\hline \multicolumn{3}{|c|}{ Execute 'gdxxrw.exe results3.gdx $0=$ results $3 . x l s$ var $=x t$} \\
\hline \multicolumn{3}{|c|}{ Execute_unload "results4.gdx" xt_swch.1 } \\
\hline \multicolumn{3}{|c|}{ Execute 'gdxxrw.exe results $4 . g d x-=$ results $4 . x l s$ var $=x t$} \\
\hline \multicolumn{3}{|c|}{$* * * * * * * * * * * * * * * * * * * * * * * * * * * * * * * * * * * * * * * * * * *$} \\
\hline \multicolumn{3}{|l|}{ *End of code } \\
\hline \multicolumn{3}{|c|}{ 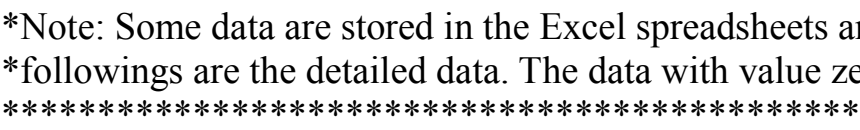 } \\
\hline \multicolumn{3}{|l|}{$\mathrm{Q}$ residue } \\
\hline & Log_weton & Mill_dryton \\
\hline KY_Adair & 53720.000 & 49749.000 \\
\hline KY_Allen & 67720.000 & 18492.000 \\
\hline $\mathrm{KY}_{-}^{-}$Anderson & 3400.000 & \\
\hline KY_Ballard & 28760.000 & 61075.000 \\
\hline KY_Barren & 62080.000 & 43844.000 \\
\hline KY_Bath & 28040.000 & \\
\hline KY Bell & 35520.000 & \\
\hline KY_Boone & 2560.000 & \\
\hline KY_Bourbon & 3360.000 & \\
\hline KY_Boyd & 11240.000 & \\
\hline KY Boyle & 15920.000 & 26862.000 \\
\hline KY_Bracken & 5640.000 & \\
\hline KY_Breathitt & 90920.000 & \\
\hline $\mathrm{KY}^{-}$Breckinridge & 76320.000 & 77757.000 \\
\hline KY_Bullitt & 14160.000 & \\
\hline KY_Butler & 43800.000 & \\
\hline KY_Caldwell & 41640.000 & 20660.000 \\
\hline KY_Calloway & 31800.000 & \\
\hline KY_Campbell & 560.000 & \\
\hline KY_Carlisle & 36120.000 & 12457.000 \\
\hline KY_Carroll & 4440.000 & \\
\hline KY_Carter & 57200.000 & 25766.000 \\
\hline KY_Casey & 93960.000 & 50035.000 \\
\hline $\mathrm{KY}^{-}$Christian & 54840.000 & 6788.000 \\
\hline KY_Clark & 3640.000 & \\
\hline KY Clay & 74640.000 & \\
\hline KY_Clinton & 59920.000 & 18077.000 \\
\hline KY_Crittenden & 63960.000 & 17637.000 \\
\hline
\end{tabular}




\begin{tabular}{|c|c|c|}
\hline KY_Cumberland & 59720.000 & 31012.000 \\
\hline KY Daviess & 19000.000 & \\
\hline $\mathrm{KY}^{-}$Edmonson & 14680.000 & 4761.000 \\
\hline KY Elliott & 21920.000 & \\
\hline $\mathrm{KY}^{-}$Estill & 46680.000 & 49318.000 \\
\hline KY Fayette & 1760.000 & \\
\hline KY_Fleming & 22760.000 & 15359.000 \\
\hline KY Floyd & 35800.000 & 14030.000 \\
\hline $\mathrm{KY}^{-}$Franklin & 480.000 & \\
\hline KY Fulton & 12200.000 & \\
\hline KY_Gallatin & 1360.000 & \\
\hline KY GäGarrard & 3200.000 & \\
\hline KY_Grant & 7000.000 & \\
\hline KY_Graves & 46800.000 & 14000.000 \\
\hline $\mathrm{KY}^{-}$Grayson & 39840.000 & 4841.000 \\
\hline KY_Green & 29400.000 & 12694.000 \\
\hline KY_Greenup & 43720.000 & 2076.000 \\
\hline $\mathrm{KY}^{-}$Hancock & 21880.000 & \\
\hline KY_Hardin & 47640.000 & 10676.000 \\
\hline KY Harlan & 141320.000 & 61955.000 \\
\hline $\mathrm{KY}^{-}$Harrison & 2240.000 & 1408.000 \\
\hline KY ${ }^{-}$Hart & 58800.000 & 22590.000 \\
\hline $\mathrm{KY}^{-}$Henderson & 11720.000 & \\
\hline KY_Henry & 9480.000 & 7670.000 \\
\hline KY_Hickman & 8720.000 & \\
\hline KY_Hopkins & 51240.000 & 19375.000 \\
\hline KY_Jackson & 20960.000 & \\
\hline $\mathrm{KY}^{-}$Jefferson & 5360.000 & \\
\hline KY Jessamine & 1800.000 & \\
\hline KY_Johnson & 20960.000 & \\
\hline $\mathrm{KY}^{-}$Kenton & 1320.000 & \\
\hline KY_Knott & 27040.000 & \\
\hline KY_Knox & 132520.000 & 54583.000 \\
\hline KY-Larue & 30520.000 & \\
\hline $\mathrm{KY}^{-}$Laurel & 199960.000 & 60641.000 \\
\hline KY Lawrence & 15080.000 & \\
\hline KY_Lee & 60280.000 & 13911.000 \\
\hline KY_Leslie & 67600.000 & \\
\hline KY Letcher & 35960.000 & \\
\hline KY_Lewis & 133960.000 & 45523.000 \\
\hline $\mathrm{KY}^{-}$Lincoln & 28440.000 & \\
\hline $\mathrm{KY}^{-}$Livingston & 48400.000 & 23005.000 \\
\hline $\mathrm{KY}^{-}$Logan & 31160.000 & 20419.000 \\
\hline $\mathrm{KY}^{-}$Lyon & 33560.000 & \\
\hline KY_McCracken & 5000.000 & \\
\hline KY_McCreary & 85440.000 & 35167.000 \\
\hline $\mathrm{KY}^{-}$McLean & 29880.000 & \\
\hline $\mathrm{KY}^{-}$Madison & 5760.000 & 17849.000 \\
\hline $\mathrm{KY}^{-}$Magoffin & 14960.000 & 123.000 \\
\hline KY-Marion & 47800.000 & 13954.000 \\
\hline KY_Marshall & 27800.000 & 11459.000 \\
\hline
\end{tabular}




\begin{tabular}{|c|c|c|}
\hline KY_Martin & 27480.000 & \\
\hline $\mathrm{KY}^{-}$Mason & 13480.000 & \\
\hline KY Meade & 26160.000 & \\
\hline KY Menifee & 29600.000 & 13725.000 \\
\hline KY_Mercer & 2520.000 & \\
\hline KY_Metcalfe & 65880.000 & 26283.000 \\
\hline KY_Monroe & 59680.000 & 55792.000 \\
\hline $\mathrm{KY}^{-}$Montgomery & 3720.000 & \\
\hline KY Morgan & 52080.000 & 33623.000 \\
\hline $\mathrm{KY}^{-}$Muhlenberg & 41280.000 & 57487.000 \\
\hline KY_Nelson & 16840.000 & 5302.000 \\
\hline KY_Nicholas & 480.000 & \\
\hline KY־-Ohio & 142120.000 & 33892.000 \\
\hline KY_Oldham & 2920.000 & \\
\hline KY- Owen & 7000.000 & \\
\hline $\mathrm{KY}^{-} \mathrm{O}$-wsley & 24320.000 & \\
\hline KY Pendleton & 2360.000 & \\
\hline KY_Perry & 51680.000 & 39866.000 \\
\hline KY_Pike & 108120.000 & 15938.000 \\
\hline KY_Powell & 36320.000 & 18624.000 \\
\hline KY־-Pulaski & 107240.000 & 71385.000 \\
\hline KY Robertson & 720.000 & \\
\hline KY Rockcastle & 41520.000 & 11207.000 \\
\hline KY_Rowan & 35680.000 & 59543.000 \\
\hline KY_Russell & 36200.000 & \\
\hline $\mathrm{KY}^{-} \mathrm{Scott}$ & 3080.000 & \\
\hline KY_Shelby & 5240.000 & 975.000 \\
\hline KY Simpson & 6280.000 & \\
\hline KY_Spencer & 1800.000 & \\
\hline KY Taylor & 60240.000 & 15275.000 \\
\hline KY_Todd & 24000.000 & 14077.000 \\
\hline KY Trigg & 59080.000 & 33357.000 \\
\hline KY_Trimble & 4200.000 & \\
\hline KY_Union & 6800.000 & \\
\hline $\mathrm{KY}^{-}$Warren & 20760.000 & \\
\hline KY Washington & 14600.000 & \\
\hline KY_Wayne & 85680.000 & 40210.000 \\
\hline KY_Webster & 23520.000 & \\
\hline KY_Whitley & 61160.000 & \\
\hline KY_Wolfe & 45520.000 & 6317.000 \\
\hline $\mathrm{VA}^{-}$Accomack & 13120.000 & \\
\hline $\mathrm{VA}^{-}$Albemarle & 79120.000 & 56572.000 \\
\hline VA_Alleghany & 59480.000 & 121996.000 \\
\hline VA_Amelia & 126760.000 & 67270.000 \\
\hline VA_Amherst & 66160.000 & 50525.000 \\
\hline VA_Appomattox & 82600.440 & \\
\hline VA_Augusta & 42400.000 & 85897.000 \\
\hline VA Bath & 38240.000 & \\
\hline $\mathrm{VA}^{-}$Bedford & 94960.000 & 53107.000 \\
\hline VA_Bland & 28080.000 & \\
\hline VA Botetourt & 50360.000 & \\
\hline
\end{tabular}




$\begin{array}{lll} & & \\ \text { VA_Brunswick } & 287520.000 & 60890.000 \\ \text { VA_Buchanan } & 11080.000 & 10603.000 \\ \text { VA_Campbell } & 134360.000 & 94607.000 \\ \text { VA_Caroline } & 127360.000 & 74974.000 \\ \text { VA_Carroll } & 123960.000 & 49831.000 \\ \text { VA_Charles_City } & 34800.000 & \\ \text { VA_Charlotte } & 195160.000 & 116491.000 \\ \text { VA_Chesterfield } & 34080.000 & \\ \text { VA_Clarke } & 11240.000 & \\ \text { VA_Craig } & 11080.000 & \\ \text { VA_Culpeper } & 41960.000 & 15843.000 \\ \text { VA_Cumberland } & 80960.000 & \\ \text { VA_Dickenson } & 160800.000 & \\ \text { VA_Essex } & 38000.000 & \\ \text { VA_Fairfax } & 10920.000 & \\ \text { VA_Fauguier } & 18280.000 & \\ \text { VA_Floyd } & 42000.000 & \\ \text { VA_Fluvanna } & 28240.000 & \\ \text { VA_Franklin } & 123120.000 & 55954.000 \\ \text { VA_Frederick } & 42640.000 & 16421.000 \\ \text { VA_Giles } & 38640.000 & \\ \text { VA_Gloucester } & 57720.000 & 30366.000 \\ \text { VA_Goochland } & 22960.000 & \\ \text { VA_Grayson } & 69880.000 & 83065.000 \\ \text { VA_Greene } & 13400.000 & \\ \text { VA_Greensville } & 114280.000 & 218601.000 \\ \text { VA_Halifax } & 226840.000 & 80514.000 \\ \text { VA_Hanover } & 34920.000 & 161587.000 \\ \text { VA_Henrico } & 9720.000 & \\ \text { VA_Henry } & 124360.000 & 75025.000 \\ \text { VA_Highland } & 48480.000 & \\ \text { VA_Isle_of_Wight } & 72800.000 & 267439.000 \\ \text { VA_James_City } & 19400.000 & \\ \text { VA_King_and_Queen } & 97280.000 & 27687.000 \\ \text { VA_King_George } & 28320.000 & \\ \text { VA_King_William } & 39920.000 & \\ \text { VA_Lancaster } & 21800.000 & \\ \text { VA_Lee } & 62040.000 & 23767.000 \\ \text { VA_Loudoun } & 35280.000 & 16033.000 \\ \text { VA_Louisa } & 97920.000 & 70482.000 \\ \text { VA_Madison } & 22640.000 & 12199.000 \\ \text { VA_Mathews } & 1920.000 & \\ \text { VA_Mecklenburg } & 151040.000 & \\ \text { VA_Middlesex } & 22000.000 & \\ \text { VA_Montgomery } & 21840.000 & 44057.000 \\ \text { VA_Nelson } & 73080.000 & \\ \text { VA_New_Kent } & 49560.000 & \\ \text { VA_Northampton } & 9880.000 & \\ \text { VA_Northumberland } & 18680.000 & \\ \text { VA_Nottoway } & 70480.000 & 218171.000 \\ \text { VA_Orange } & 37080.000 & \\ \end{array}$




\begin{tabular}{|c|c|c|}
\hline VA_Page & 3000.000 & \\
\hline VA_Patrick & 104880.000 & 69580.000 \\
\hline VA_Pittsylvania & 246480.000 & 76054.000 \\
\hline VA_Powhatan & 54200.000 & \\
\hline VA_Prince_Edward & 69920.000 & \\
\hline VA Prince George & 67120.000 & 78040.000 \\
\hline VA_Prince_William & 20880.000 & \\
\hline VA_Pulaskī & 4120.000 & \\
\hline VA_Rappahannock & 9560.000 & \\
\hline VA_Richmond & 40120.000 & 40167.000 \\
\hline VA_Roanoke & 9640.000 & \\
\hline VA_Rockbridge & 68000.000 & 116550.000 \\
\hline VA Rockingham & 21360.000 & \\
\hline VA_Russell & 17680.000 & \\
\hline VA_Scott & 61280.000 & 99738.000 \\
\hline VA_Shenandoah & 25760.000 & 1940.000 \\
\hline VA_Smyth & 29720.000 & \\
\hline VA_Southampton & 263600.000 & \\
\hline VA_Spotsylvania & 41360.000 & 23664.000 \\
\hline VA_Stafford & 24800.000 & \\
\hline VA_Surry & 101000.000 & \\
\hline VA_Sussex & 158120.000 & \\
\hline VA_Tazewell & 13640.000 & \\
\hline VA_Warren & 12840.000 & \\
\hline VA_Westmoreland & 34720.000 & \\
\hline VA_Wise & 32640.000 & \\
\hline VA_Wythe & 78160.000 & 20059.000 \\
\hline VA- York & 3600.000 & \\
\hline PA_Adams & 161784.760 & 10290.000 \\
\hline PA_Allegheny & 17113.840 & 4358.000 \\
\hline PA_Armstrong & 78595.600 & 19484.000 \\
\hline PA_Beaver & 3432.080 & \\
\hline $\mathrm{PA}^{-}$Bedford & 145168.000 & 61313.000 \\
\hline PA_Berks & 31963.680 & 6011.000 \\
\hline PA_Blair & 41914.360 & \\
\hline PA_Bradford & 99689.560 & 23643.000 \\
\hline PA_Bucks & 5060.040 & 6556.000 \\
\hline PA_Butler & 48171.800 & 13020.000 \\
\hline PA_Cambria & 117037.080 & 39831.000 \\
\hline PA_Cameron & 47291.320 & 22523.000 \\
\hline PA_Carbon & 9362.400 & 157.000 \\
\hline PA_Centre & 123939.960 & 16996.000 \\
\hline PA_Chester & 38937.280 & 724.000 \\
\hline PA_Clarion & 86717.240 & 49051.000 \\
\hline PA_Clearfield & 244030.240 & 60530.000 \\
\hline PA_Clinton & 81785.400 & 11383.000 \\
\hline PA_Columbia & 79352.400 & 11768.000 \\
\hline PA_Crawford & 79921.920 & 45456.000 \\
\hline PA_Cumberland & 33769.280 & 1821.000 \\
\hline PA_Dauphin & 43869.000 & 22407.000 \\
\hline PA_Delaware & 1442.800 & \\
\hline
\end{tabular}




\begin{tabular}{|c|c|c|}
\hline PA_Elk & 188453.480 & 47704.000 \\
\hline PA_Erie & 26250.680 & 12135.000 \\
\hline PA_Fayette & 91118.720 & 53298.000 \\
\hline PA_Forest & 101200.840 & \\
\hline PA_Franklin & 154585.960 & 68747.000 \\
\hline PA_Fulton & 103865.560 & 15257.000 \\
\hline $\mathrm{PA}^{-}$Greene & 39453.120 & 1958.000 \\
\hline $\mathrm{PA}^{-}$Huntingdon & 175498.720 & 53667.000 \\
\hline PA_Indiana & 104658.880 & 31588.000 \\
\hline $\mathrm{PA}^{-}$Jefferson & 140959.240 & 81295.000 \\
\hline PA_Juniata & 119690.320 & 68954.000 \\
\hline PA_Lackawanna & 22904.320 & 22100.000 \\
\hline PA_Lancaster & 46490.120 & 26032.000 \\
\hline PA_Lawrence & 37260.440 & 3991.000 \\
\hline PA_Lebanon & 28439.320 & 55144.000 \\
\hline PA_Lehigh & 6437.160 & 594.000 \\
\hline PA_Luzerne & 52769.120 & 2667.000 \\
\hline PA_Lycoming & 165341.240 & 66079.000 \\
\hline PA_McKean & 110846.840 & 44710.000 \\
\hline $\mathrm{PA}^{-}$Mercer & 83215.120 & 25061.000 \\
\hline PA_Mifflin & 77379.160 & 19369.000 \\
\hline PA_Monroe & 18786.960 & 2045.000 \\
\hline PA_Montgomery & 9368.040 & 765.000 \\
\hline PA_Montour & 1712.680 & \\
\hline PA_Northampton & 2190.640 & 877.000 \\
\hline $\mathrm{PA}^{-}$Northumberland & 30765.040 & \\
\hline PA_Perry & 109840.400 & 22224.000 \\
\hline PA_Philadelphia & 796.360 & \\
\hline PA_Pike & 27731.440 & \\
\hline PA_Potter & 321324.400 & 192813.000 \\
\hline PA_Schuylkill & 106854.800 & 17204.000 \\
\hline PA_Snyder & 62929.400 & 25728.000 \\
\hline PA Somerset & 155606.440 & 34286.000 \\
\hline PA_Sullivan & 128881.240 & 5239.000 \\
\hline PA_Susquehanna & 79256.000 & 12184.000 \\
\hline PA_Tioga & 132425.520 & 18297.000 \\
\hline PA_Union & 26210.240 & 21195.000 \\
\hline PA_Venango & 131210.680 & 29324.000 \\
\hline $\mathrm{PA}_{-}^{-}$Warren & 189551.160 & 37086.000 \\
\hline PA_Washington & 25863.600 & 676. \\
\hline PA_Wayne & 56661.600 & 20512.000 \\
\hline PA_Westmoreland & 73465.920 & 28302.000 \\
\hline PA_Wyoming & 55606.960 & 13217.000 \\
\hline PA_York & 64229.800 & 18491.000 \\
\hline MD_Allegany & 106098.160 & 222507.000 \\
\hline MD_Anne_Arundel & 1.400 & \\
\hline MD_Baltimore & 12951.520 & \\
\hline MD_Calvert & 5006.680 & \\
\hline MD_Carroll & 1719.680 & \\
\hline MD_Cecil & 42134.480 & \\
\hline MD_Charles & 32675.920 & \\
\hline
\end{tabular}




\begin{tabular}{|c|c|c|}
\hline MD_Dorchester & 47163.880 & \\
\hline MD Frederick & 3813.600 & \\
\hline MD_Garrett & 184257.680 & \\
\hline MD Harford & 19157.680 & \\
\hline MD_Howard & 3698.960 & \\
\hline MD_Kent & 2952.800 & \\
\hline MD_Montgomery & 2874.320 & \\
\hline MD_Prince_Georges & 19339.400 & \\
\hline MD Saint Marys & 23875.040 & \\
\hline MD_Somerset & 86168.080 & \\
\hline MD_Talbot & 12861.640 & \\
\hline MD_Washington & 19271.360 & \\
\hline MD_Wicomico & 117654.680 & \\
\hline MD_Worcester & 92468.120 & \\
\hline $\mathrm{OH}^{-}$Adams & 55429.400 & 9518.960 \\
\hline OH_Allen & 3916.640 & 6678.120 \\
\hline $\mathrm{OH}_{-}$Ashland & 17564.760 & \\
\hline $\mathrm{OH}$ Ashtabula & 13145.720 & \\
\hline OH_Athens & 43002.080 & \\
\hline $\mathrm{OH}^{-}$Auglaize & 8580.840 & \\
\hline $\mathrm{OH}^{-}$Belmont & 17330.920 & 50947.200 \\
\hline $\mathrm{OH}^{-}$Brown & 9202.000 & 5603.380 \\
\hline OH_Butler & 4311.800 & \\
\hline OH_Carroll & 20634.920 & \\
\hline OH_Champaign & 528.080 & \\
\hline $\mathrm{OH}_{-}^{-}$Clark & 1235.080 & \\
\hline $\mathrm{OH}_{-}^{-}$Clermont & 13131.440 & \\
\hline $\mathrm{OH}^{-}$Clinton & 477.360 & 7360.200 \\
\hline $\mathrm{OH}^{-}$Columbiana & 16914.280 & \\
\hline OH_Coshocton & 46848.800 & 9108.900 \\
\hline $\mathrm{OH}_{-}^{-} \mathrm{Crawford}$ & 972.400 & \\
\hline OH_Cuyahoga & 1162.640 & \\
\hline $\mathrm{OH}^{-}$Darke & 725.600 & \\
\hline OH_Defiance & 828.160 & \\
\hline OH_Delaware & 1339.800 & 3644.720 \\
\hline $\mathrm{OH}^{-}$Erie & 141.800 & \\
\hline $\mathrm{OH}_{-}$Fairfield & 9308.880 & 8001.680 \\
\hline OH_Fayette & 787.680 & \\
\hline $\mathrm{OH}_{-}^{-}$Franklin & 1836.680 & \\
\hline OH_Fulton & 154.120 & \\
\hline $\mathrm{OH}^{-}$Gallia & 21577.480 & 13550.540 \\
\hline $\mathrm{OH}^{-}$Geauga & 22926.800 & \\
\hline OH_Greene & 1988.560 & \\
\hline OH_Guernsey & 30919.840 & \\
\hline $\mathrm{OH}$-Hamilton & 11050.600 & \\
\hline $\mathrm{OH}^{-}$Hancock & 1288.920 & \\
\hline $\mathrm{OH}_{-}$Hardin & 2710.920 & \\
\hline $\mathrm{OH}_{-}^{-}$Harrison & 34708.600 & \\
\hline $\mathrm{OH}$ _Highland & 21122.440 & \\
\hline $\mathrm{OH}$ _Hocking & 100675.000 & \\
\hline $\mathrm{OH}$ Holmes & 33293.720 & \\
\hline
\end{tabular}




$\begin{array}{lll}\text { OH_Huron } & 1.440 & \\ \text { OH_Jackson } & 156035.440 & 24346.660 \\ \text { OH_Jefferson } & 18256.640 & \\ \text { OH_Knox } & 28692.600 & 7001.180 \\ \text { OH_Lake } & 2660.200 & \\ \text { OH_Lawrence } & 11477.000 & \\ \text { OH_Licking } & 17832.400 & \\ \text { OH_Logan } & 4359.880 & \\ \text { OH_Lorain } & 30.520 & \\ \text { OH_Lucas } & 9.360 & \\ \text { OH_Mahoning } & 13900.120 & \\ \text { OH_Marion } & 1270.320 & \\ \text { OH_Medina } & 6619.040 & \\ \text { OH_Meigs } & 62115.760 & 38705.140 \\ \text { OH_Mercer } & 3528.480 & \\ \text { OH_Miami } & 716.080 & \\ \text { OH_Montgomery } & 1741.080 & \\ \text { OH_Morgan } & 41876.120 & \\ \text { OH_Morrow } & 823.000 & \\ \text { OH_Muskingum } & 30057.760 & \\ \text { OH_Noble } & 12660.560 & \\ \text { OH_Ottawa } & 14.080 & \\ \text { OH_Paulding } & 1123.080 & \\ \text { OH_Perry } & 31440.200 & \\ \text { OH_Pickaway } & 3890.640 & \\ \text { OH_Pike } & 144788.440 & 46843.120 \\ \text { OH_Portage } & 11487.640 & \\ \text { OH_Preble } & 4373.880 & \\ \text { OH_Putnam } & 3185.360 & \\ \text { OH_Richland } & 6234.200 & \\ \text { OH_Ross } & 102619.280 & 7572.480 \\ \text { OH_Sandusky } & 23.440 & \\ \text { OH_Scioto } & 138557.320 & 25745.040 \\ \text { OH_Seneca } & 23.440 & \\ \text { OH_Shelby } & 3600.560 & \\ \text { OH_Stark } & 22046.960 & \\ \text { OH_Summit } & 3174.560 & \\ \text { OH_Trumbull } & 19256.880 & \\ \text { OH_Tuscarawas } & 64747.880 & 27043.080 \\ \text { OH__Union } & 2318.200 & \\ \text { OH_Van_Wert } & 1104.480 & \\ \text { OH_Vinton } & 159405.600 & 166041.800 \\ \text { OH_Warren } & 477.360 & \\ \text { OH_Washington } & 28081.440 & 72513.340 \\ \text { OH_Wayne } & 21387.000 & \\ \text { OH_Wood } & 23.440 & \\ \text { OH_Wyandot } & 411.480 & \\ \text { WV_Barbour } & 23885.000 & \\ \text { WV_Boone } & 52539.000 & \\ \text { WV_Braxton } & 85558.000 & \\ \text { WV_Cabell } & 19352.000 & \\ \end{array}$




\begin{tabular}{|c|c|c|}
\hline WV_Calhoun & 38323.000 & \\
\hline WV-Clay & 61457.000 & 11358.720 \\
\hline WV_Doddridge & 49434.000 & 7377.600 \\
\hline WV_Fayette & 108269.000 & 10440.000 \\
\hline WV'Gilmer & 41961.000 & 27.840 \\
\hline WV_Grant & 25182.000 & 2004.480 \\
\hline WV_Greenbrier & 70650.000 & 38057.280 \\
\hline WV ${ }^{-}$Hampshire & 29328.000 & \\
\hline $\mathrm{WV}^{-}$Hardy & 19834.000 & 1559.040 \\
\hline WV Harrison & 43089.000 & \\
\hline WV Jackson & 26038.000 & 1670.400 \\
\hline WV_Kanawha & 158324.000 & 25195.200 \\
\hline WV_Lincoln & 18459.000 & 334.080 \\
\hline WV_Logan & 16380.000 & \\
\hline $\mathrm{WV}^{-}$Lewis & 40551.000 & \\
\hline WV ${ }^{-}$Marion & 42215.000 & \\
\hline WV ${ }^{-}$Marshall & 31743.000 & \\
\hline WV_McDowell & 70707.000 & \\
\hline WV_Mason & 18170.000 & \\
\hline $\mathrm{WV}^{-}$Mercer & 44234.000 & 556.800 \\
\hline WV_Mineral & 12671.000 & 2784.000 \\
\hline WV Mingo & 69417.000 & 33633.500 \\
\hline $\mathrm{WV}^{-}$Monongalia & 28661.000 & 27.840 \\
\hline WV_Monroe & 42422.000 & 4732.800 \\
\hline WV_Nicholas & 87436.000 & 88893.120 \\
\hline WV_Pendleton & 28134.000 & \\
\hline WV_Pleasants & 23575.000 & 11136.000 \\
\hline WV Pocahontas & 29431.000 & 44488.320 \\
\hline WV Preston & 90343.000 & 58742.400 \\
\hline WV Putnam & 23471.000 & \\
\hline WV Raleigh & 80051.000 & 23664.000 \\
\hline WV_Randolph & 113787.000 & 123600.100 \\
\hline WV Ritchie & 63995.000 & 1740.000 \\
\hline WV_Roane & 44518.000 & 278.400 \\
\hline WV Summers & 12775.000 & 5568.000 \\
\hline $\mathrm{WV}^{-}$Taylor & 23885.000 & 417.600 \\
\hline WV Tucker & 36716.000 & \\
\hline WV_Tyler & 23575.000 & \\
\hline WV Upshur & 65941.000 & 32016.000 \\
\hline WV_Wayne & 22491.000 & \\
\hline WV Webster & 88773.000 & 8268.480 \\
\hline $\mathrm{WV}^{-}$Wetzel & 47065.000 & 4454.400 \\
\hline WV_Wirt & 39527.000 & \\
\hline WV_Wood & 30324.000 & 84.077 \\
\hline $\mathrm{WV}^{-}$Wyoming & 30324.000 & 8.352 \\
\hline
\end{tabular}

$\underline{\text { dis }}$

WV_Boone

KY_Adair $\quad 204.000$ 


$\begin{array}{ll}\text { KY_Allen } & 258.000 \\ \text { KY_Anderson } & 169.000 \\ \text { KY_Ballard } & 407.000 \\ \text { KY_Barren } & 238.000 \\ \text { KY_Bath } & 107.000 \\ \text { KY_Bell } & 138.000 \\ \text { KY_Boone } & 172.000 \\ \text { KY_Bourbon } & 134.000 \\ \text { KY_Boyd } & 50.000 \\ \text { KY_Boyle } & 165.000 \\ \text { KY_Bracken } & 130.000 \\ \text { KY_Breathitt } & 93.000 \\ \text { KY_Breckinridge } & 255.000 \\ \text { KY_Bullitt } & 213.000 \\ \text { KY_Butler } & 275.000 \\ \text { KY_Caldwell } & 340.000 \\ \text { KY_Calloway } & 372.000 \\ \text { KY_Campbell } & 153.000 \\ \text { KY_Carlisle } & 405.000 \\ \text { KY_Carroll } & 188.000 \\ \text { KY_Carter } & 65.000 \\ \text { KY_Casey } & 179.000 \\ \text { KY_Christian } & 324.000 \\ \text { KY_Clark } & 130.000 \\ \text { KY_Clay } & 125.000 \\ \text { KY_Clinton } & 206.000 \\ \text { KY_Crittenden } & 348.000 \\ \text { KY_Cumberland } & 215.000 \\ \text { KY_Daviess } & 291.000 \\ \text { KY_Edmonson } & 252.000 \\ \text { KY_Elliott } & 72.000 \\ \text { KY_Estill } & 121.000 \\ \text { KY_Fayette } & 146.000 \\ \text { KY_Fleming } & 108.000 \\ \text { KY_Floyd } & 59.000 \\ \text { KY_Franklin } & 167.000 \\ \text { KY_Fulton } & 420.000 \\ \text { KY_Gallatin } & 175.000 \\ \text { KY_Garrard } & 155.000 \\ \text { KY_Grant } & 155.000 \\ \text { KY_Graves } & 387.000 \\ \text { KY_Grayson } & 249.000 \\ \text { KY_Green } & 210.000 \\ \text { KY_Greenup } & 66.000 \\ \text { KY_Hancock } & 271.000 \\ \text { KY_Hardin } & 224.000 \\ \text { KY_Harlan } & 118.000 \\ \text { KY_Harrison } & 138.000 \\ \text { KY_Hart } & 231.000 \\ \text { KY_Henderson } & 316.000 \\ \text { KY_Henry } & 185.000 \\ & \\ & \end{array}$




$\begin{array}{ll} & \\ \text { KY_Hickman } & 407.000 \\ \text { KY_Hopkins } & 317.000 \\ \text { KY_Jackson } & 127.000 \\ \text { KY_Jefferson } & 215.000 \\ \text { KY_Jessamine } & 152.000 \\ \text { KY_Johnson } & 57.000 \\ \text { KY_Kenton } & 162.000 \\ \text { KY_Knott } & 82.000 \\ \text { KY_Knox } & 141.000 \\ \text { KY_Larue } & 218.000 \\ \text { KY_Laurel } & 141.000 \\ \text { KY_Lawrence } & 44.000 \\ \text { KY_Lee } & 109.000 \\ \text { KY_Leslie } & 106.000 \\ \text { KY_Letcher } & 86.000 \\ \text { KY_Lewis } & 90.000 \\ \text { KY_Lincoln } & 161.000 \\ \text { KY_Livingston } & 368.000 \\ \text { KY_Logan } & 292.000 \\ \text { KY_Lyon } & 351.000 \\ \text { KY_McCracken } & 381.000 \\ \text { KY_McCreary } & 174.000 \\ \text { KY_McLean } & 301.000 \\ \text { KY_Madison } & 138.000 \\ \text { KY_Magoffin } & 72.000 \\ \text { KY_Marion } & 192.000 \\ \text { KY_Marshall } & 370.000 \\ \text { KY_Martin } & 42.000 \\ \text { KY_Mason } & 114.000 \\ \text { KY_Meade } & 239.000 \\ \text { KY_Menifee } & 100.000 \\ \text { KY_Mercer } & 168.000 \\ \text { KY_Metcalfe } & 223.000 \\ \text { KY_Monroe } & 234.000 \\ \text { KY_Montgomery } & 117.000 \\ \text { KY_Morgan } & 81.000 \\ \text { KY_Muhlenberg } & 301.000 \\ \text { KY_Nelson } & 201.000 \\ \text { KY_Nicholas } & 123.000 \\ \text { KY_Ohio } & 282.000 \\ \text { KY_Oldham } & 196.000 \\ \text { KY_Owen } & 168.000 \\ \text { KY_Owsley } & 110.000 \\ \text { KY_Pendleton } & 144.000 \\ \text { KY_Perry } & 95.000 \\ \text { KY_Pike } & 56.000 \\ \text { KY_Powell } & 113.000 \\ \text { KY_Pulaski } & 168.000 \\ \text { KY_Robertson } & 126.000 \\ \text { KY_Rockcastle } & 147.000 \\ \text { KY_Rowan } & 90.000 \\ \text { KY } & \\ & \end{array}$




$\begin{array}{ll} & \\ \text { KY_Russell } & 194.000 \\ \text { KY_Scott } & 150.000 \\ \text { KY_Shelby } & 187.000 \\ \text { KY_Simpson } & 278.000 \\ \text { KY_Spencer } & 193.000 \\ \text { KY_Taylor } & 201.000 \\ \text { KY_Todd } & 307.000 \\ \text { KY_Trigg } & 341.000 \\ \text { KY_Trimble } & 195.000 \\ \text { KY_Union } & 335.000 \\ \text { KY_Warren } & 266.000 \\ \text { KY_Washington } & 189.000 \\ \text { KY_Wayne } & 187.000 \\ \text { KY_Webster } & 324.000 \\ \text { KY_Whitley } & 159.000 \\ \text { KY_Wolfe } & 98.000 \\ \text { KY_Woodford } & 160.000 \\ \text { VA_Accomack } & 336.000 \\ \text { VA_Albemarle } & 181.000 \\ \text { VA_Alleghany } & 142.000 \\ \text { VA_Amelia } & 215.000 \\ \text { VA_Amherst } & 154.000 \\ \text { VA_Appomattox } & 170.000 \\ \text { VA_Arlington } & 261.000 \\ \text { VA_Augusta } & 149.000 \\ \text { VA_Bath } & 110.000 \\ \text { VA_Bedford } & 134.000 \\ \text { VA_Bland } & 76.000 \\ \text { VA_Botetourt } & 112.000 \\ \text { VA_Brunswick } & 235.000 \\ \text { VA_Buchanan } & 56.000 \\ \text { VA_Campbell } & 158.000 \\ \text { VA_Caroline } & 243.000 \\ \text { VA_Carroll } & 107.000 \\ \text { VA_Charles_City } & 264.000 \\ \text { VA_Charlotte } & 187.000 \\ \text { VA_Chesterfield } & 240.000 \\ \text { VA_Clarke } & 220.000 \\ \text { VA_Craig } & 100.000 \\ \text { VA_Culpeper } & 209.000 \\ \text { VA_Cumberland } & 198.000 \\ \text { VA_Dickenson } & 72.000 \\ \text { VA_Essex } & 269.000 \\ \text { VA_Fairfax } & 250.000 \\ \text { VA_Fauguier } & 222.000 \\ \text { VA_Floyd } & 114.000 \\ \text { VA_Fluvanna } & 194.000 \\ \text { VA_Franklin } & 128.000 \\ \text { VA_Frederick } & 211.000 \\ \text { VA_Giles } & 78.000 \\ \text { VA_Gloucester } & 292.000 \\ \text { VA } & \end{array}$




\begin{tabular}{ll} 
& \\
VA_Goochland & 216.000 \\
VA_Grayson & 105.000 \\
VA_Greene & 184.000 \\
VA_Greensville & 253.000 \\
VA_Halifax & 181.000 \\
VA_Hanover & 243.000 \\
VA_Henrico & 240.000 \\
VA_Henry & 143.000 \\
VA_Highland & 123.000 \\
VA_Isle_of_Wight & 291.000 \\
VA_James_City & 284.000 \\
VA_King_and_Queen & 270.000 \\
VA_King_George & 252.000 \\
VA_King_William & 263.000 \\
VA_Lancaster & 292.000 \\
VA_Lee & 119.000 \\
VA_Loudoun & 241.000 \\
VA_Louisa & 207.000 \\
VA_Madison & 194.000 \\
VA_Mathews & 303.000 \\
VA_Mecklenburg & 211.000 \\
VA_Middlesex & 286.000 \\
VA_Montgomery & 99.000 \\
VA_Nelson & 161.000 \\
VA_New_Kent & 267.000 \\
VA_Northampton & 325.000 \\
VA_Northumberland & 291.000 \\
VA_Nottoway & 300.000 \\
VA_Orange & 201.000 \\
VA_Page & 186.000 \\
VA_Patrick & 129.000 \\
VA_Pittsylvania & 157.000 \\
VA_Powhatan & 215.000 \\
VA_Prince_Edward & 194.000 \\
VA_Prince_George & 254.000 \\
VA_Prince_William & 239.000 \\
VA_Pulaski & 90.000 \\
VA_Rappahannock & 203.000 \\
VA_Richmond & 275.000 \\
VA_Roanoke & 114.000 \\
VA_Rockbridge & 130.000 \\
VA_Rockingham & 161.000 \\
VA_Russell & 81.000 \\
VA_Scott & 107.000 \\
VA_Shenandoah & 187.000 \\
VA_Smyth & 86.000 \\
VA_Southampton & 277.000 \\
VA_Spotsylvania & 230.000 \\
VA_Stafford & 240.000 \\
VA_Surry & 280.000 \\
VA_Sussex & 261.000 \\
\hline
\end{tabular}




\begin{tabular}{ll} 
& \\
VA_Tazewell & 66.000 \\
VA_Warren & 205.000 \\
VA_Westmoreland & 271.000 \\
VA_Wise & 86.000 \\
VA_Wythe & 86.000 \\
VA_York & 296.000 \\
PA_Adams & 275.000 \\
PA_Allegheny & 191.000 \\
PA_Armstrong & 226.000 \\
PA_Beaver & 198.000 \\
PA_Bedford & 223.000 \\
PA_Berks & 352.000 \\
PA_Blair & 245.000 \\
PA_Bradford & 383.000 \\
PA_Bucks & 390.000 \\
PA_Butler & 218.000 \\
PA_Cambria & 235.000 \\
PA_Cameron & 304.000 \\
PA_Carbon & 378.000 \\
PA_Centre & 292.000 \\
PA_Chester & 358.000 \\
PA_Clarion & 253.000 \\
PA_Clearfield & 272.000 \\
PA_Clinton & 314.000 \\
PA_Columbia & 350.000 \\
PA_Crawford & 263.000 \\
PA_Cumberland & 288.000 \\
PA_Dauphin & 305.000 \\
PA_Delaware & 368.000 \\
PA_Elk & 284.000 \\
PA_Erie & 295.000 \\
PA_Fayette & 169.000 \\
PA_Forest & 268.000 \\
PA_Franklin & 258.000 \\
PA_Fulton & 242.000 \\
PA_Greene & 154.000 \\
PA_Huntingdon & 264.000 \\
PA_Indiana & 227.000 \\
PA_Jefferson & 259.000 \\
PA_Juniata & 293.000 \\
PA_Lackawanna & 400.000 \\
PA_Lancaster & 326.000 \\
PA_Lawrence & 217.000 \\
PA_Lebanon & 329.000 \\
PA_Lehigh & 381.000 \\
PA_Luzerne & 385.000 \\
PA_Lycoming & 336.000 \\
PA_McKean & 314.000 \\
PA_Mercer & 234.000 \\
PA_Mifflin & 286.000 \\
PA_Monroe & 406.000 \\
\hline &
\end{tabular}




\begin{tabular}{ll} 
& \\
PA_Montgomery & 375.000 \\
PA_Montour & 342.000 \\
PA_Northampton & 396.000 \\
PA_Northumberland & 330.000 \\
PA_Perry & 296.000 \\
PA_Philadelphia & 383.000 \\
PA_Pike & 436.000 \\
PA_Potter & 326.000 \\
PA_Schuylkill & 350.000 \\
PA_Snyder & 316.000 \\
PA_Somerset & 199.000 \\
PA_Sullivan & 365.000 \\
PA_Susquehanna & 408.000 \\
PA_Tioga & 349.000 \\
PA_Union & 330.000 \\
PA_Venango & 253.000 \\
PA_Warren & 297.000 \\
PA_Washington & 168.000 \\
PA_Wayne & 424.000 \\
PA_Westmoreland & 197.000 \\
PA_Wyoming & 393.000 \\
PA_York & 303.000 \\
MD_Allegany & 197.000 \\
MD_Anne_Arundel & 294.000 \\
MD_Baltimore & 295.000 \\
MD_Baltimore_City & 393.000 \\
MD_Calvert & 285.000 \\
MD_Caroline & 329.000 \\
MD_Carroll & 279.000 \\
MD_Cecil & 340.000 \\
MD_Charles & 265.000 \\
MD_Dorchester & 313.000 \\
MD_Frederick & 255.000 \\
MD_Garrett & 160.000 \\
MD_Harford & 311.000 \\
MD_Howard & 281.000 \\
MD_Kent & 320.000 \\
MD_Montgomery & 261.000 \\
MD_Prince_Georges & 279.000 \\
MD_Queen_Annes & 318.000 \\
MD_Saint_Marys & 281.000 \\
MD_Somerset & 333.000 \\
MD_Talbot & 315.000 \\
MD_Washington & 246.000 \\
MD_Wicomico & 339.000 \\
MD_Worcester & 349.000 \\
OH_Adams & 107.000 \\
OH_Allen & 223.000 \\
OH_Ashland & 196.000 \\
OH_Ashtabula & 260.000 \\
OH_Athens & 89.000 \\
\hline
\end{tabular}




$\begin{array}{ll} & \\ \text { OH_Auglaize } & 215.000 \\ \text { OH_Belmont } & 147.000 \\ \text { OH_Brown } & 127.000 \\ \text { OH_Butler } & 175.000 \\ \text { OH_Carroll } & 178.000 \\ \text { OH_Champaign } & 176.000 \\ \text { OH_Clark } & 168.000 \\ \text { OH_Clermont } & 147.000 \\ \text { OH_Clinton } & 145.000 \\ \text { OH_Columbiana } & 195.000 \\ \text { OH_Coshocton } & 152.000 \\ \text { OH_Crawford } & 199.000 \\ \text { OH_Cuyahoga } & 236.000 \\ \text { OH_Darke } & 207.000 \\ \text { OH_Defiance } & 261.000 \\ \text { OH_Delaware } & 169.000 \\ \text { OH_Erie } & 239.000 \\ \text { OH_Fairfield } & 123.000 \\ \text { OH_Fayette } & 135.000 \\ \text { OH_Franklin } & 148.000 \\ \text { OH_Fulton } & 271.000 \\ \text { OH_Gallia } & 57.000 \\ \text { OH_Geauga } & 245.000 \\ \text { OH_Greene } & 161.000 \\ \text { OH_Guernsey } & 136.000 \\ \text { OH_Hamilton } & 164.000 \\ \text { OH_Hancock } & 228.000 \\ \text { OH_Hardin } & 203.000 \\ \text { OH_Harrison } & 158.000 \\ \text { OH_Henry } & 261.000 \\ \text { OH_Highland } & 126.000 \\ \text { OH_Hocking } & 107.000 \\ \text { OH_Holmes } & 172.000 \\ \text { OH_Huron } & 224.000 \\ \text { OH_Jackson } & 82.000 \\ \text { OH_Jefferson } & 171.000 \\ \text { OH_Knox } & 165.000 \\ \text { OH_Lake } & 255.000 \\ \text { OH_Lawrence } & 58.000 \\ \text { OH_Licking } & 143.000 \\ \text { OH_Logan } & 190.000 \\ \text { OH_Lorain } & 230.000 \\ \text { OH_Lucas } & 266.000 \\ \text { OH_Madison } & 154.000 \\ \text { OH_Mahoning } & 219.000 \\ \text { OH_Marion } & 188.000 \\ \text { OH_Medina } & 212.000 \\ \text { OH_Meigs } & 68.000 \\ \text { OH_Mercer } & 227.000 \\ \text { OH_Miami } & 189.000 \\ \text { OH_Monroe } & 123.000 \\ \end{array}$




$\begin{array}{ll}\text { OH_Montgomery } & 175.000 \\ \text { OH_Morgan } & 110.000 \\ \text { OH_Morrow } & 181.000 \\ \text { OH_Muskingum } & 131.000 \\ \text { OH_Noble } & 117.000 \\ \text { OH_Ottawa } & 246.000 \\ \text { OH_Paulding } & 259.000 \\ \text { OH_Perry } & 116.000 \\ \text { OH_Pickaway } & 123.000 \\ \text { OH_Pike } & 97.000 \\ \text { OH_Portage } & 216.000 \\ \text { OH_Preble } & 192.000 \\ \text { OH_Putnam } & 237.000 \\ \text { OH_Richland } & 191.000 \\ \text { OH_Ross } & 109.000 \\ \text { OH_Sandusky } & 238.000 \\ \text { OH_Scioto } & 79.000 \\ \text { OH_Seneca } & 223.000 \\ \text { OH_Shelby } & 199.000 \\ \text { OH_Stark } & 191.000 \\ \text { OH_Summit } & 209.000 \\ \text { OH_Trumbull } & 225.000 \\ \text { OH_Tuscarawas } & 169.000 \\ \text { OH_Union } & 172.000 \\ \text { OH_Van_Wert } & 244.000 \\ \text { OH_Vinton } & 90.000 \\ \text { OH_Warren } & 161.000 \\ \text { OH_Washington } & 96.000 \\ \text { OH_Wayne } & 190.000 \\ \text { OH_Williams } & 277.000 \\ \text { OH_Wood } & 249.000 \\ \text { OH_Wyandot } & 207.000 \\ \text { WV_Barbour } & 121.000 \\ \text { WV_Braxton } & 73.000 \\ \text { WV_Cabell } & 32.000 \\ \text { WV_Calhoun } & 71.000 \\ \text { WV_Clay } & 48.000 \\ \text { WV_Doddridge } & 102.000 \\ \text { WV_Fayette } & 38.000 \\ \text { WV_Gilmer } & 80.000 \\ \text { WV_Grant } & 159.000 \\ \text { WV_Greenbrier } & 61.000 \\ \text { WV_Hampshire } & 187.000 \\ \text { WV_Hardy } & 168.000 \\ \text { WV_Harrison } & 116.000 \\ \text { WV_Jackson } & 53.000 \\ \text { WV_Kanawha } & 23.000 \\ \text { WV_Lincoln } & 22.000 \\ \text { WV_Logan } & 21.000 \\ \text { WV_Lewis } & 99.000 \\ \text { WV_Marion } & 130.000 \\ & \end{array}$




$\begin{array}{ll}\text { WV_Marshall } & 139.000 \\ \text { WV_McDowell } & 45.000 \\ \text { WV_Mason } & 48.000 \\ \text { WV_-Mercer } & 61.000 \\ \text { WV_Mineral } & 170.000 \\ \text { WV_Mingo } & 32.000 \\ \text { WV_Monongalia } & 148.000 \\ \text { WV_Monroe } & 76.000 \\ \text { WV_Nicholas } & 54.000 \\ \text { WV_Pendleton } & 140.000 \\ \text { WV_Pleasants } & 98.000 \\ \text { WV_Pocahontas } & 94.000 \\ \text { WV_Preston } & 153.000 \\ \text { WV_Putnam } & 32.000 \\ \text { WV_Raleigh } & 38.000 \\ \text { WV_Randolph } & 118.000 \\ \text { WV_Ritchie } & 89.000 \\ \text { WV_Roane } & 57.000 \\ \text { WV_Summers } & 57.000 \\ \text { WV_Taylor } & 131.000 \\ \text { WV_Tucker } & 137.000 \\ \text { WV_Tyler } & 110.000 \\ \text { WV_Upshur } & 107.000 \\ \text { WV_Wayne } & 37.000 \\ \text { WV_Webster } & 81.000 \\ \text { WV_Wetzel } & 120.000 \\ \text { WV_Wirt } & 73.000 \\ \text { WV_Wood } & 79.000 \\ \text { WV_Wyoming } & 36.000 \\ \end{array}$

ddis

WV_Boone

$\begin{array}{ll}\text { WV_Barbour } & 121.000 \\ \text { WV_Boone } & 20.000 \\ \text { WV_Braxton } & 73.000 \\ \text { WV_Cabell } & 32.000 \\ \text { WV_Calhoun } & 71.000 \\ \text { WV_Clay } & 48.000 \\ \text { WV__Doddridge } & 102.000 \\ \text { WV_Fayette } & 38.000 \\ \text { WV_Gilmer } & 80.000 \\ \text { WV_Grant } & 159.000 \\ \text { WV_Greenbrier } & 61.000 \\ \text { WV_Hampshire } & 187.000 \\ \text { WV_Hardy } & 168.000 \\ \text { WV_Harrison } & 116.000 \\ \text { WV_Jackson } & 53.000 \\ \text { WV_Kanawha } & 23.000\end{array}$




$\begin{array}{ll} & \\ \text { WV_Lincoln } & 22.000 \\ \text { WV_Logan } & 21.000 \\ \text { WV_Lewis } & 99.000 \\ \text { WV_Marion } & 130.000 \\ \text { WV_-Marshall } & 139.000 \\ \text { WV_McDowell } & 45.000 \\ \text { WV_-Mason } & 48.000 \\ \text { WV_Mercer } & 61.000 \\ \text { WV_-Mineral } & 170.000 \\ \text { WV_Mingo } & 32.000 \\ \text { WV_Monongalia } & 148.000 \\ \text { WV_Monroe } & 76.000 \\ \text { WV_Nicholas } & 54.000 \\ \text { WV_Pendleton } & 140.000 \\ \text { WV_Pleasants } & 98.000 \\ \text { WV_Pocahontas } & 94.000 \\ \text { WV_Preston } & 153.000 \\ \text { WV_Putnam } & 32.000 \\ \text { WV_Raleigh } & 38.000 \\ \text { WV_Randolph } & 118.000 \\ \text { WV_Ritchie } & 89.000 \\ \text { WV_Roane } & 57.000 \\ \text { WV_Summers } & 57.000 \\ \text { WV_Taylor } & 131.000 \\ \text { WV_Tucker } & 137.000 \\ \text { WV_Tyler } & 110.000 \\ \text { WV_Upshur } & 107.000 \\ \text { WV_Wayne } & 37.000 \\ \text { WV_Webster } & 81.000 \\ \text { WV_Wetzel } & 120.000 \\ \text { WV_Wirt } & 73.000 \\ \text { WV_Wood } & 79.000 \\ \text { WV_Wyoming } & 36.000 \\ & \\ & \end{array}$

Acre

Hay_land Coal_claimed_acre

WV_Barbour

WV_Boone

$15300.000 \quad 9566.000$

24543.000

$9600.000 \quad 739.000$

WV_Braxton

$7700.000 \quad 2.700$

WV Calhoun

7700.000

$2400.000 \quad 5256.000$

WV_Clay

$11300.000 \quad 228.000$

$5300.000 \quad 21950.000$

$8200.000 \quad 2616.000$

$15000.000 \quad 889.000$

WV_Grant

$24700.000 \quad 4016.000$

WV_Greenbrier

21600.000 


\begin{tabular}{|c|c|c|}
\hline WV_Hardy & 17200.000 & \\
\hline $\mathrm{WV}^{-}$Harrison & 19900.000 & 88374.000 \\
\hline WV_Jackson & 21700.000 & 24.000 \\
\hline WV_Kanawha & 3300.000 & 17060.000 \\
\hline WV_Lincoln & 3900.000 & 1326.000 \\
\hline WV_Logan & 54149.000 & \\
\hline WV_Lewis & 12400.000 & 21100.000 \\
\hline WV_Marion & 10900.000 & 12515.000 \\
\hline WV ${ }^{-}$Marshall & 20500.000 & 168.000 \\
\hline WV_McDowell & 50150.000 & \\
\hline WV_Mason & 22100.000 & 1709.000 \\
\hline WV Mercer & 10000.000 & 4423.000 \\
\hline WV_Mineral & 14700.000 & 8824.000 \\
\hline WV Mingo & 43844.000 & \\
\hline WV Monongalia & 12800.000 & 18788.000 \\
\hline WV_Monroe & 20300.000 & \\
\hline WV_Nicholas & 10300.000 & 8697.000 \\
\hline WV Pendleton & 16800.000 & \\
\hline WV_Pleasants & 4100.000 & 48.000 \\
\hline WV Pocahontas & 16000.000 & 508.000 \\
\hline WV_Preston & 31200.000 & 35733.000 \\
\hline WV_Putnam & 10700.000 & 5082.000 \\
\hline WV_Raleigh & 8200.000 & 6566.000 \\
\hline WV_Randolph & 14500.000 & 8235.000 \\
\hline WV_Ritchie & 13500.000 & \\
\hline WV-Roane & 17700.000 & \\
\hline WV Summers & 8700.000 & 17.000 \\
\hline WV Taylor & 9900.000 & 2985.000 \\
\hline WV_Tucker & 5000.000 & 6423.000 \\
\hline WV_Tyler & 9100.000 & \\
\hline WV_Upshur & 11900.000 & 3605.000 \\
\hline WV_Wayne & 4200.000 & 2823.000 \\
\hline WV Webster & 1700.000 & 921.000 \\
\hline $\mathrm{WV}^{-}$Wetzel & 7000.000 & 36.000 \\
\hline WV Wirt & 6500.000 & \\
\hline WV_Wood & 17100.000 & \\
\hline WV_Wyoming & 18112.000 & \\
\hline \multicolumn{3}{|l|}{ Q_coal } \\
\hline & Coal_prod & Coal_use \\
\hline WV Barbour & 2171.000 & 2171.000 \\
\hline WV_Boone & 33628.000 & 7723.000 \\
\hline WV Braxton & 335.000 & \\
\hline WV_Clay & 3743.000 & \\
\hline WV_Fayette & 3956.000 & 507.000 \\
\hline WV Grant & 122.000 & 122.000 \\
\hline WV_Greenbrier & 667.000 & \\
\hline WV_Harrison & 360.000 & 360.000 \\
\hline
\end{tabular}




$\begin{array}{lll}\text { WV_Kanawha } & 12342.000 & 12048.000 \\ \text { WV_Lincoln } & 737.000 & \\ \text { WV_Logan } & 14655.000 & \\ \text { WV_Marion } & 13285.000 & 13285.000 \\ \text { WV_Marshall } & 9745.000 & 9469.000 \\ \text { WV_McDowell } & 6190.000 & \\ \text { WV_Mason } & 590.000 & 590.000 \\ \text { WV_Mineral } & 55.000 & \\ \text { WV_Mingo } & 12205.000 & \\ \text { WV_Monongalia } & 10673.000 & 4219.000 \\ \text { WV_Nicholas } & 4425.000 & \\ \text { WV_Preston } & 1479.000 & 961.000 \\ \text { WV_Raleigh } & 9132.000 & \\ \text { WV_Randolph } & 1121.000 & 1121.000 \\ \text { WV_Tucker } & 2761.000 & 2761.000 \\ \text { WV_Upshur } & 2036.000 & 139.000 \\ \text { WV_Wayne } & 4719.000 & 3872.000 \\ \text { WV_Webster } & 5110.000 & \\ \text { WV_Wyoming } & 4598.000 & \\ \end{array}$

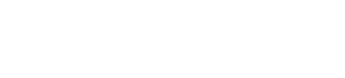

